Prepared in cooperation with the City of Jacksonville, Onslow Water and Sewer Authority, and the United States Marine Corps Base Camp Lejeune

\title{
Simulation of Groundwater Flow and Saltwater Movement in the Onslow County Area, North Carolina: Predevelopment-2010
}

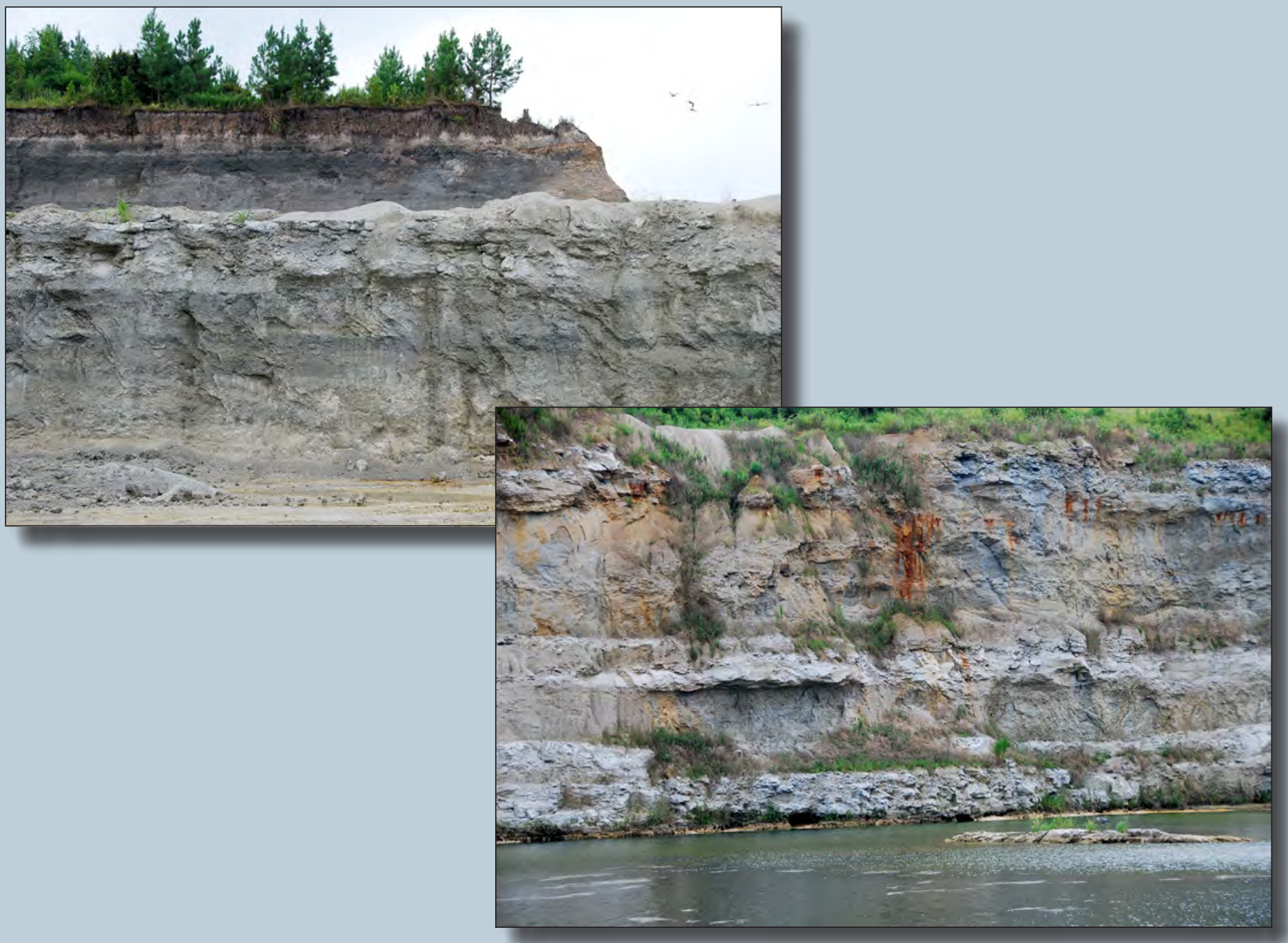

Scientific Investigations Report 2013-5236 
Cover photographs. Left: Martin Marietta Belgrade Quarry. Right: Martin Marietta Onslow Quarry (photographs by Groundwater Management Associates). 


\section{Simulation of Groundwater Flow and Saltwater Movement in the Onslow County Area, North Carolina: Predevelopment-2010}

By Jason M. Fine and Eve L. Kuniansky

Prepared in cooperation with the City of Jacksonville, Onslow Water and Sewer Authority, and the United States Marine Corps Base Camp Lejeune

Scientific Investigations Report 2013-5236 


\title{
U.S. Department of the Interior SALLY JEWELL, Secretary
}

\section{U.S. Geological Survey Suzette M. Kimball, Acting Director}

\author{
U.S. Geological Survey, Reston, Virginia: 2014
}

For more information on the USGS - the Federal source for science about the Earth, its natural and living resources, natural hazards, and the environment, visit http://Www.usgs.gov or call 1-888-ASK-USGS.

For an overview of USGS information products, including maps, imagery, and publications, visit http://WwW.usgs.gov/pubprod

To order this and other USGS information products, visit http://store.usgs.gov

Any use of trade, firm, or product names is for descriptive purposes only and does not imply endorsement by the U.S. Government.

Although this information product, for the most part, is in the public domain, it also may contain copyrighted materials as noted in the text. Permission to reproduce copyrighted items must be secured from the copyright owner.

Suggested citation:

Fine, J.M., and Kuniansky, E.L, 2014, Simulation of groundwater flow and saltwater movement in the Onslow County area, North Carolina: Predevelopment-2010: U.S. Geological Survey Scientific Investigations Report 2013-5236, 106 p., http://dx.doi.org/10.3133/sir20135236.

ISSN 2328-0328 (online) 


\section{Acknowledgments}

The authors would like to thank Nathaniel Wilson, Jeff Lautier, and Gabrielle Chianese of the North Carolina Division of Water Resources for supplying water-level, water-use, and waterchemistry data.

The authors would also like to thank Bruce Campbell, Michael Fienen, Christian Langevin, and Claire Tiedeman, of the U.S. Geological Survey, for their technical support in the model construction and calibration process. Additionally, the authors appreciate the technical peer reviews of the report by Melinda Chapman, Matthew Petkewich, and Leonard Konikow of the U.S. Geological Survey. 


\section{Contents}

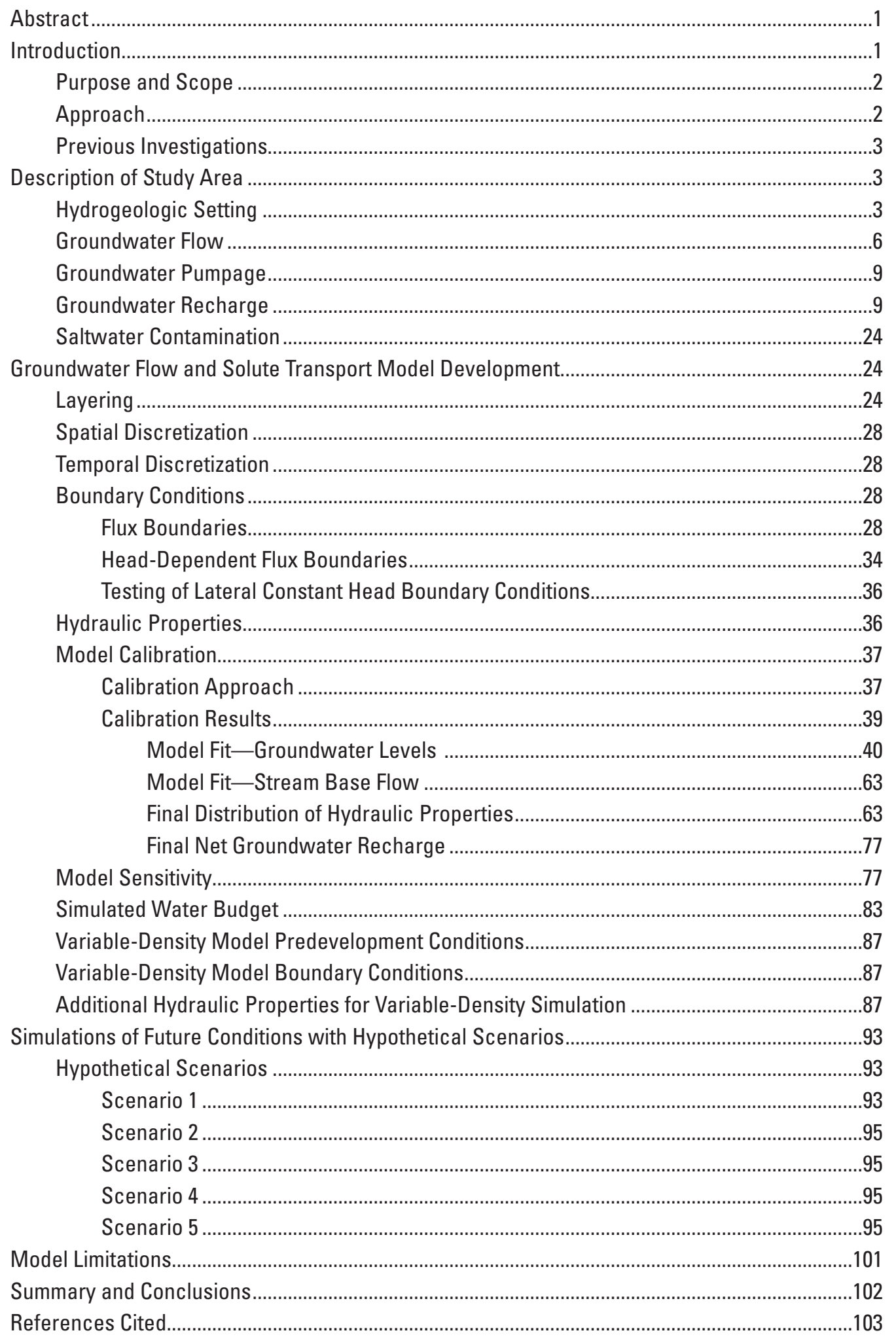




\section{Figures}

1. Location of the study area, Onslow County, North Carolina ..

2. Correlation chart of North Carolina Coastal Plain geologic and hydrogeologic units.

3. Cross section $E-E^{\prime}$ showing hydrogeologic strike and cross section $C-C^{\prime}$ showing hydrogeologic dip in the study area..

4. Generalized block diagram of the aquifers and confining units of the Atlantic Coastal Plain of North and South Carolina showing generalized directions of flow for surface runoff and regional groundwater flow.

5. Groundwater use by aquifer in wells in the model area

6. Long-term mean monthly Thornthwaite water budget for Maysville, North Carolina

7. Monthly Thornthwaite water budget for Maysville, North Carolina, climate data $1980-2010$

8. Flow duration curve for the New River near Gum Branch, North Carolina, 1949-2009

9. Generalized dip cross section showing how aquifers and confining units correspond with model layers

10. Maps showing zones used in model calibration for model layer 1 , model layer 2, model layer 3, model layer 4, model layer 5, model layer 6, model layer 7 , model layer 8 , model layer 9 , model layer 10 , and model layer 11

11. Map showing model grid and major surface-water features of the study area..............30

12. Map showing the cells of equal net groundwater recharge for each stress period used in the model.

13. Map showing location of commercial, industrial, mining, and public-supply wells and model layer for each well, and location of livestock farm wells

14. Map showing location of drains, constant head, and general head boundary conditions applied to the surficial aquifer, model layer 1

15. Map showing selected wells, simulated streams, and location of general head and constant head boundary conditions applied to the upper Castle Hayne confining unit, model layer 2

16. Observed versus simulated water-levels for predevelopment conditions ......................41

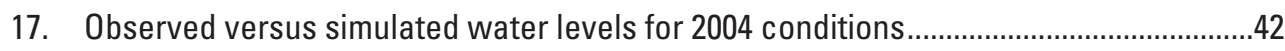

18. Observed versus simulated water levels for 2008 conditions...........................................4

19. Observed versus simulated water levels for wells with continuous data .......................44

20. Map showing simulated potentiometric surfaces and water-level residuals for the predevelopment time period for the upper Castle Hayne, lower Castle Hayne, Beaufort, Peedee, and Black Creek aquifers.

21. Map showing simulated potentiometric surfaces and water-level residuals for the 2004 time period for the upper Castle Hayne, lower Castle Hayne, Beaufort, Peedee, and Black Creek aquifers.

22. Map showing simulated potentiometric surfaces and residuals for the 2008 time period for upper Castle Hayne, lower Castle Hayne, Beaufort, Peedee, and Black Creek aquifers 
23. Map showing residuals for the continuous recorder wells for the surficial, upper Castle Hayne, lower Castle Hayne, Beaufort, Peedee, and Black

Creek aquifers

24. Hydrographs showing simulated and observed water levels at selected wells in the upper Castle Hayne aquifer.

25. Hydrographs showing simulated and observed water levels at selected wells in the lower Castle Hayne aquifer

26. Hydrographs showing simulated and observed water levels at selected wells in the Beaufort aquifer

27. Hydrographs showing simulated and observed water levels at selected wells in the Peedee aquifer

28. Hydrographs showing simulated and observed water levels at selected wells in the Black Creek aquifer

29. Map of the final distribution of horizontal hydraulic conductivity and location of pilot points and wells of the surficial aquifer, model layer 1

30. Map of the final distribution of horizontal hydraulic conductivity and location of pilot points of the upper Castle Hayne confining unit, model layer 2

31. Map of the final distribution of horizontal hydraulic conductivity and location of pilot points and wells of the upper Castle Hayne aquifer, model layer 3

32. Map of the final distribution of horizontal hydraulic conductivity and location of pilot points of the lower Castle Hayne confining unit, model layer 4

33. Map of the final distribution of hydraulic conductivity and location of pilot points and wells of the lower Castle Hayne aquifer, model layer 5

34. Map of the final distribution of horizontal hydraulic conductivity and location of pilot points of the Beaufort confining unit, model layer 6 .

35. Map of the final distribution of horizontal hydraulic conductivity and location of pilot points and wells of the Beaufort aquifer, model layer 7

36. Map of the final distribution of horizontal hydraulic conductivity and location of pilot points of the Peedee confining unit, model layer 8.

37. Map of the final distribution of horizontal hydraulic conductivity and location of pilot points and wells of the Peedee aquifer, model layer 9

38. Map of the final distribution of horizontal hydraulic conductivity and location of pilot points of the Black Creek confining unit, model layer 10.

39. Map of the final distribution of horizontal hydraulic conductivity and location of pilot points and wells of the Black Creek aquifer, model layer 11

40. Relative composite sensitivities for the aquifer parameters and aquifer parameter pilot points

41. Graph of and locations for pilot points with relative composite sensitivities values greater than 0.025

42. Bar graph showing components of the simulated water budget predevelopment through 2010

43. Initial chloride concentrations of Castle Hayne and Beaufort aquifers and confining units

44. Initial chloride concentrations of the Peedee aquifer and confining unit

45. Initial chloride concentrations of the Black Creek aquifer and confining unit 
46. Chloride concentrations for general head and constant head boundaries of layer 1

47. Chloride concentrations for general head and constant head boundaries of layer 2 .

48. Computed change of simulated water levels between 2010 and 2028 for scenario 1 in the upper Castle Hayne aquifer, lower Castle Hayne aquifer, and Black Creek aquifer.

49. Computed change of simulated water levels between 2010 and 2028 for scenario 2 in the upper Castle Hayne aquifer lower Castle Hayne aquifer, and Black Creek aquifer.

50. Computed change of simulated water levels between 2010 and 2028 for scenario 3 in the A. upper Castle Hayne aquifer; B, lower Castle Hayne aquifer; and C, Black Creek aquifer

51. Computed change of simulated water levels between 2010 and 2028 for scenario 4 in the upper Castle Hayne aquifer, lower Castle Hayne aquifer and Black Creek aquifer.

52. Computed change of simulated water levels between 2010 and 2100 for scenario 5 in the upper Castle Hayne aquifer, lower Castle Hayne aquifer, and Black Creek aquifer

53. Computed change of simulated chloride levels between 2010 and 2100 for scenario 5 in the upper Castle Hayne aquifer, and the lower Castle Hayne aquifer

\section{Tables}

1. Climate stations in the vicinity of Onslow County, North Carolina and summary data for 1980-2010

2. Monthly estimated net groundwater recharge at climate sites in the vicinity of Onslow County, North Carolina

3. Calendar period associated with each model stress period

4. Compilation of hydraulic properties calculated from aquifer tests in the

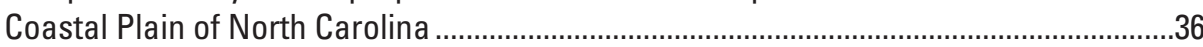

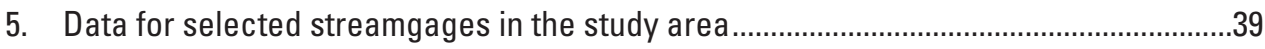

6. Calibration statistics for simulated heads for predevelopment conditions ......................41

7. Calibration statistics for simulated heads for 2004 conditions ....................................42

8. Calibration statistics for simulated heads for 2008 conditions ......................................43

9. Calibration statistics for simulated heads in wells with continuous data .......................44

10. Hydaulic properties in the model zones representing the aquifer and

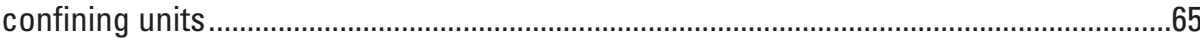

11. Initial and final net groundwater recharge for each stress period...................................78

12. Simulated predevelopment water budget by model layer.................................................85

13. Simulated water budget by model layer for stress period 72 , fourth quarter, 2010

14. Calibration statistics for simulated heads in wells for all layers after conversion to variable-density model 


\section{Conversion Factors}

Inch/pound to SI

\begin{tabular}{|c|c|c|}
\hline Multiply & By & To obtain \\
\hline \multicolumn{3}{|c|}{ Length } \\
\hline inch (in.) & 2.54 & centimeter $(\mathrm{cm})$ \\
\hline foot $(\mathrm{ft})$ & 0.3048 & meter $(\mathrm{m})$ \\
\hline mile (mi) & 1.609 & kilometer (km) \\
\hline \multicolumn{3}{|c|}{ Area } \\
\hline square mile $\left(\mathrm{mi}^{2}\right)$ & 2.590 & square kilometer $\left(\mathrm{km}^{2}\right)$ \\
\hline \multicolumn{3}{|c|}{ Flow rate } \\
\hline inch per year (in/yr) & 2.54 & centimeter per year $(\mathrm{cm} / \mathrm{yr})$ \\
\hline $\begin{array}{l}\text { cubic foot per second } \\
\qquad\left(\mathrm{ft}^{3} / \mathrm{s}\right)\end{array}$ & 0.02832 & $\begin{array}{l}\text { cubic meter per second } \\
\qquad\left(\mathrm{m}^{3} / \mathrm{s}\right)\end{array}$ \\
\hline cubic foot per day $\left(\mathrm{ft}^{3} / \mathrm{d}\right)$ & 0.02832 & cubic meter per day $\left(\mathrm{m}^{3} / \mathrm{d}\right)$ \\
\hline $\begin{array}{l}\text { million gallons per day } \\
\qquad(\mathrm{Mgal} / \mathrm{d})\end{array}$ & 0.04381 & $\begin{array}{l}\text { cubic meter per second } \\
\qquad\left(\mathrm{m}^{3} / \mathrm{s}\right)\end{array}$ \\
\hline \multicolumn{3}{|c|}{ Hydraulic conductivity } \\
\hline foot per day (ft/d) & 0.348 & meter per day $(\mathrm{m} / \mathrm{d})$ \\
\hline
\end{tabular}

SI to Inch/pound

\begin{tabular}{lll}
\hline Multiply & By & \multicolumn{1}{c}{ To obtain } \\
\hline & Length & \\
\hline millimeter (mm) & 0.03937 & inch (in.) \\
meter $(\mathrm{m})$ & 3.281 & foot (ft) \\
\hline
\end{tabular}

Temperature in degrees Celsius $\left({ }^{\circ} \mathrm{C}\right)$ may be converted to degrees Fahrenheit $\left({ }^{\circ} \mathrm{F}\right)$ as follows:

${ }^{\circ} \mathrm{F}=\left(1.8 \times{ }^{\circ} \mathrm{C}\right)+32$

Temperature in degrees Fahrenheit $\left({ }^{\circ} \mathrm{F}\right)$ may be converted to degrees Celsius $\left({ }^{\circ} \mathrm{C}\right)$ as follows:

${ }^{\circ} \mathrm{C}=\left({ }^{\circ} \mathrm{F}-32\right) / 1.8$

Vertical coordinate information is referenced to the North American Vertical Datum of 1988 (NAVD 88).

Horizontal coordinate information is referenced to the North American Datum of 1983 (NAD 83).

Elevation, as used in this report, refers to the distance above a vertical datum.

Specific conductance is given in microsiemens per centimeter at 25 degrees Celsius $(\mu \mathrm{S} / \mathrm{cm}$ at $25^{\circ} \mathrm{C}$ ).

Concentrations of chemical constituents in water are given either in milligrams per liter (mg/L) or grams per liter $(\mathrm{g} / \mathrm{L})$. 


\section{Abbreviations}

$\begin{array}{ll}\text { ATSDR } & \text { Agency for Toxic Substances and Disease Registry } \\ \text { CCPCUA } & \text { Central Coastal Plain Capacity Use Area } \\ \text { CIMP } & \text { Commercial, Industrial, Mining, and Public-Supply } \\ \text { GIS } & \text { Geographic Information System } \\ \text { NC ACP } & \text { North Carolina Atlantic Coastal Plain } \\ \text { NCDWR } & \text { North Carolina Division of Water Resources } \\ \text { NED } & \text { National Elevation Dataset } \\ \text { NRCS } & \text { Natural Resources Conservation Service } \\ \text { USGS } & \text { U.S. Geological Survey } \\ \text { WHAT } & \text { Web based Hydrograph Analysis Tool }\end{array}$




\title{
Simulation of Groundwater Flow and Saltwater Movement in the Onslow County Area, North Carolina: Predevelopment-2010
}

\author{
By Jason M. Fine and Eve L. Kuniansky
}

\section{Abstract}

Onslow County, North Carolina, is located within the designated Central Coastal Plain Capacity Use Area (CCPCUA). The CCPCUA was designated by law as a result of groundwater level declines of as much as 200 feet during the past four decades within aquifers in rocks of Cretaceous age in the central Coastal Plain of North Carolina and a depletion of water in storage from increased groundwater withdrawals in the area. The declines and depletion of water in storage within the Cretaceous aquifers increase the potential for saltwater migration - both lateral encroachment and upward leakage of brackish water. Within the CCPCUA, a reduction in groundwater withdrawals over a period of 16 years from 2003 to 2018 is mandated. Under the CCPCUA rules, withdrawals in excess of 100,000 gallons per day from any of the Cretaceous aquifer well systems are subject to water-use reductions of as much as 75 percent. To assess the effects of the CCPCUA rules and to assist with groundwater-management decisions, a numerical model was developed to simulate the groundwater flow and chloride concentrations in the surficial, Castle Hayne, Beaufort, Peedee, and Black Creek aquifers in the Onslow County area. The model was used to (1) simulate groundwater flow from 1900 to 2010; (2) assess chloride movement throughout the aquifer system; and (3) create hypothetical scenarios of future groundwater development.

After calibration of a groundwater flow model and conversion to a variable-density model, five scenarios were created to simulate future groundwater conditions in the Onslow County area: (1) full implementation of the CCPCUA rules with three phases of withdrawal reductions simulated through 2028; (2) implementation of only phase 1 withdrawal reductions of the CCPCUA rules and simulated through 2028; (3) implementation of only phases 1 and 2 withdrawal reductions of the CCPCUA rules and simulated through 2028; (4) full implementation of the CCPCUA rules with the addition of withdrawals from the Castle Hayne aquifer in Onslow County at the fully permitted amount in the final stress period and simulated through 2028; and (5) full implementation of the CCPCUA rules as in scenario 1 except simulated through 2100. Results from the scenarios give an indication of the water-level recovery in the Black Creek aquifer throughout each phase of the CCPCUA rules in Onslow County.

Furthermore, as development of the Castle Hayne aquifers was increased in the scenarios, cones of depression were created around pumping centers. Additionally, the scenarios indicated little to no change in chloride concentrations for the time periods simulated.

\section{Introduction}

Groundwater withdrawals from the Black Creek and Upper Cape Fear aquifers during the past four decades have resulted in depletion of groundwater stored in these aquifers composed of rocks of Cretaceous age. Groundwater levels have declined as much as $200 \mathrm{feet}(\mathrm{ft})$ in the central Coastal Plain of North Carolina (North Carolina Division of Water Resources, 2013a). Because of these declines, the increased potential for lateral saltwater migration along the coast and upward leakage of brackish water from deeper aquifers prompted the North Carolina Division of Water Resources (NCDWR) to institute the Central Coastal Plain Capacity Use Area (CCPCUA) rules for 15 counties, effective August 1, 2002 (North Carolina Division of Water Resources, 2013a). Under the CCPCUA rules, a groundwater withdrawal of more than 100,000 gallons per day from wells in the Cretaceous aquifers is subject to a water-use reduction of as much as 75 percent over a 16 -year period. The first phase of the CCPCUA, implemented in 2008, was a 25 percent reduction from 2003 permitted withdrawals from Cretaceous aquifers. The second phase, to be implemented in 2013, requires an additional 25 percent reduction (50 percent total) from 2003 permitted withdrawals from Cretaceous aquifers. The third phase of the CCPCUA requires an additional 25 percent reduction (75 percent total) from 2003 permitted withdrawals from Cretaceous aquifers. The reduced amount of water withdrawn from the Cretaceous aquifers can be supplemented by increasing withdrawals from alternative non-Cretaceous sources in the study area. 
Onslow County is located on the coast of North Carolina in the Coastal Plain physiographic province. The Black Creek aquifer, which is composed predominantly of sand of Cretaceous age, is a major source for water suppliers in Onslow County. In order to meet the required reductions in withdrawals from the Cretaceous aquifers and continue to meet demand, water suppliers in Onslow and the surrounding counties have shifted withdrawals from the Black Creek aquifer to the Castle Hayne aquifer as an alternative source. The Castle Hayne aquifer is shallower than the Black Creek aquifer and is composed of carbonate rocks of Tertiary age, which may make it susceptible to saltwater encroachment and anthropogenic contamination.

The effects of increased development and use of the Castle Hayne aquifer and decreased use of the Black Creek aquifer on water levels and saltwater migration in Onslow County are unknown. To provide a better understanding of these potential effects on groundwater resources of the Onslow County region, the U.S. Geological Survey (USGS), in cooperation with the City of Jacksonville, the United States Marine Corps Base Camp Lejeune, and the Onslow Water and Sewer Authority, began an investigation in 2007 to delineate and describe the groundwater flow system in the Onslow County area using a numerical groundwater flow model and variabledensity solute transport model.

The USGS developed a digital groundwater flow and variable-density solute transport model to provide information and a simulation tool to the water suppliers of the Onslow County region for possible use when making future groundwater-resource decisions. This report documents the groundwater model and hypothetical future scenarios created for the North Carolina Coastal Plain aquifers in the Onslow County region.

\section{Purpose and Scope}

The purpose of this report is to document a digital groundwater flow and variable-density model for the surficial, Castle Hayne, Beaufort, Peedee, and Black Creek aquifers and confining units of the Onslow County, North Carolina, area. The model is designed to simulate groundwater flows and saltwater movement throughout the aquifer system as a result of the transfer of water-use withdrawals from the deep Black Creek aquifer to the shallower Castle Hayne aquifer. The objectives of the model are to (1) simulate groundwater flow from predevelopment (1900) to 2010, (2) estimate saltwater movement throughout the aquifer system, and (3) predict future conditions of the system if several hypothetical scenarios were to be implemented.

This report documents the hydrologic setting, model construction and calibration, calibration results, sensitivity analysis, variable-density model results, and simulated future conditions to the year 2100. Five possible future-condition scenarios were tested with the calibrated model: (1) full implementation of the CCPCUA rules and simulated through 2028; (2) implementation of only phase 1 of the CCPCUA rules and simulated through 2028; (3) implementation of only phases 1 and 2 of the CCPCUA rules and simulated through 2028; (4) full implementation of the CCPCUA rules; however, withdrawals from the Castle Hayne aquifer in Onslow County are withdrawn at their fully permitted amount in the final stress period and simulated through 2028; and (5) full implementation of the CCPCUA rules and simulated through 2100. With each scenario, the reduction of withdrawals from the Black Creek aquifer was offset by increased withdrawals from other sources (the Castle Hayne aquifer in Onslow County). These scenarios were designed to show water-resource managers in the Onslow County area how the simulation model might assist in making future management decisions.

\section{Approach}

This study was conducted in three parts. The first part of the project, which is documented in Fine (2008), consisted of refining the hydrogeologic framework of the study area and was the groundwork used for the development of the groundwater-flow model. In the second part, a conceptual model of the groundwater flow system was built using the hydrogeologic framework from phase one of the study and hydrologic data from multiple reports and sources. Hydraulic-property, water-use, climate, and water-level data for the model were gathered from North Carolina State agencies, project partners, National Oceanic and Atmospheric Administration, and USGS databases and reports for model construction and calibration. These data also included synoptic groundwater-level data collected in 2008 and 2009 as part of this study. From this conceptual model, a finite-difference model (MODFLOW-2000, Harbaugh and others, 2000) was calibrated to simulate the groundwater flow in the study area from 1900 to 2010. The model was calibrated by approximating steady-state (predevelopment) water levels and simulating transient conditions through 2010. During the calibration process, the conceptual model was evaluated and refined. The sensitivity of the calibrated model to uncertainty in the model parameters was evaluated to determine the relative importance of the parameters to the simulated results.

In the third and final part of the study, the calibrated finite-difference groundwater-flow model was converted to a variable-density flow model (SEAWAT-2000, Langevin and others, 2007) to estimate saltwater movement throughout the system. Specific conductance and chloride data were obtained from the North Carolina Division of Water Resources database and previous USGS investigations; however, there was a lack of groundwater sites with long-term chloride data. The variable-density model was not calibrated for chloride; therefore, the variable-density model is used for illustrative purposes only. The variable-density model was run from predevelopment to 2010, and the head residuals were checked to ensure they were almost identical to the freshwater-only model; thus, no further calibration or modification of the location of the freshwater/saltwater no-flow boundary in the freshwater model was required. The variable-density model was then used to simulate a variety of future scenarios incorporating a variety of hypothetical pumping and climatic situations. 


\section{Previous Investigations}

Several groundwater modeling investigations have been conducted in or that encompass the study area. Eimers and others (1990) produced a regional model that simulated groundwater declines in the Cretaceous aquifers of the North Carolina Atlantic Coastal Plain (NC ACP). Giese and others (1997) produced a regional groundwater numerical model that simulated flow in all aquifers in the $\mathrm{NC} \mathrm{ACP}$ as part of the USGS Regional Aquifer-System Analysis Program. The most recent regional groundwater model of North Carolina was produced by Campbell and Coes (2010) as part of the USGS Groundwater Resources Program regional groundwater studies. Campbell and Coes (2010) simulated the entire Coastal Plain aquifer system of southern Virginia, North Carolina, South Carolina, and northeastern Georgia. Campbell and Coes (2010) calibrated this model to predevelopment, 1980, and 2004 water-level conditions. Several local models have recently been produced by the Agency for Toxic Substances and Disease Registry (ATSDR) as part of a contamination investigation of the United States Marine Corps Base Camp Lejeune study area (Faye and Valenzuela, 2007). The models developed by the ATSDR to study contaminant transport are localized in nature and, thus, were not used for the regional model framework datasets in this study.

Previous modeling reports provide simulated and observed potentiometric maps for areas that include or are within the study area. Harden and others (2004) produced a local potentiometric map of the surficial aquifer at Camp Lejeune, North Carolina. Kuniansky and others (2009) developed a regression approach for developing a potentiometric map of the surficial aquifer of the southern Virginia, North Carolina, South Carolina, and northeastern Georgia Coastal Plain that was used in the simulation by Campbell and Coes (2010). DePaul and others (2008) produced a report on water-level changes in aquifers of the Atlantic Coastal Plain for predevelopment to 2000, which contains both simulated and observed potentiometric maps that include aquifers in the study area (aquifer nomenclature is not always the same as in this report).

The delineation of the aquifers and confining units in the study area were recently revised for southern Virginia, North Carolina, South Carolina, and northeastern Georgia (Gellici and Lautier, 2010). Fine (2008) developed detailed cross sections of the aquifers and confining units for Onslow County. Additionally, a detailed hydrogeologic framework at Camp Lejeune was developed by Cardinell and others (1993).

Hydraulic-property and well data were compiled for southern Virginia, North Carolina, South Carolina, and northeastern Georgia by Harrelson and Fine (2006). McSwain and Nagy (2011) compiled transmissivity and yield data for northern New Hanover County, which is adjacent to Onslow County. Hydraulic properties from multiple observation well aquifer tests of the surficial aquifer in North Carolina at five sites were published in Smith and Chapman (2005).

\section{Description of Study Area}

The study area encompasses about 2,000 square miles $\left(\mathrm{mi}^{2}\right)$, which includes parts of Carteret, Onslow, Jones, Duplin, Lenoir, and Pender Counties and their adjacent offshore areas in the southeastern part of the Coastal Plain physiographic province of North Carolina (fig. 1). The study area lies within a larger 19,316 $\mathrm{mi}^{2}$ model area (fig. 1), which extends to natural hydrologic boundaries, including the Fall Line of the Coastal Plain physiographic province to the northwest, the theoretical freshwater/saltwater interface to the southeast, an approximated groundwater divide to the southwest, and an approximated groundwater flow line to the northeast.

\section{Hydrogeologic Setting}

The hydrogeology of the Coastal Plain consists of an eastward dipping wedge of interbedded sand, clay, and limestone layers of Quaternary to Cretaceous age overlying crystalline bedrock of pre-Cretaceous age (fig. 2). The aquifers underlying Onslow County, in descending order, are the surficial, upper and lower Castle Hayne, Beaufort, Peedee, Black Creek, and Upper and Lower Cape Fear aquifers. The aquifers are separated from one another by seven different confining units of various thicknesses. Mapping of the hydrogeologic units and more detail about the units are discussed in Gellici and Lautier (2010) and Fine (2008). Information about the units was modified from Fine (2008) and is summarized in this section.

The surficial aquifer is an important part of the groundwater flow system, because it is the primary source of recharge for the deeper aquifers and is the source of the majority of base flow for the area's streams and rivers (Winner and Coble, 1996). This unconfined to confined aquifer is composed mostly of sand, silt, and clay of Quaternary age (fig. 2). On the basis of cross sections $C-C^{\prime}$ and $E-E^{\prime}$ (figs. 1 and 3), the sediments of the surficial aquifer may have been deposited over an eroded surface, and several older aquifers and confining units are no longer present particularly in the northwestern to western part of the study area (fig. 2). In the most recent update of the hydrogeologic framework, the surficial aquifer extends to the basement rocks near the Fall Line (updip); however, the deeper permeable zones near the Fall Line typically are referred to by local drillers as the Black Creek aquifer (Gellici and Lautier, 2010). These Quaternary-age strata form a heterogeneous aquifer composed of near horizontal sequences of permeable and less permeable layers of varying thickness and lateral extent. With the exception of irrigation and private homeowner supply wells, the surficial aquifer generally is unused in the study area (North Carolina Division of Water Resources, 2013b).

Tertiary-age marine sediments of the Belgrade, River Bend, and Castle Hayne Limestone Formations compose the Castle Hayne aquifer (Lyke and Winner, 1990) (fig. 2), which is a highly productive aquifer composed of limestone 


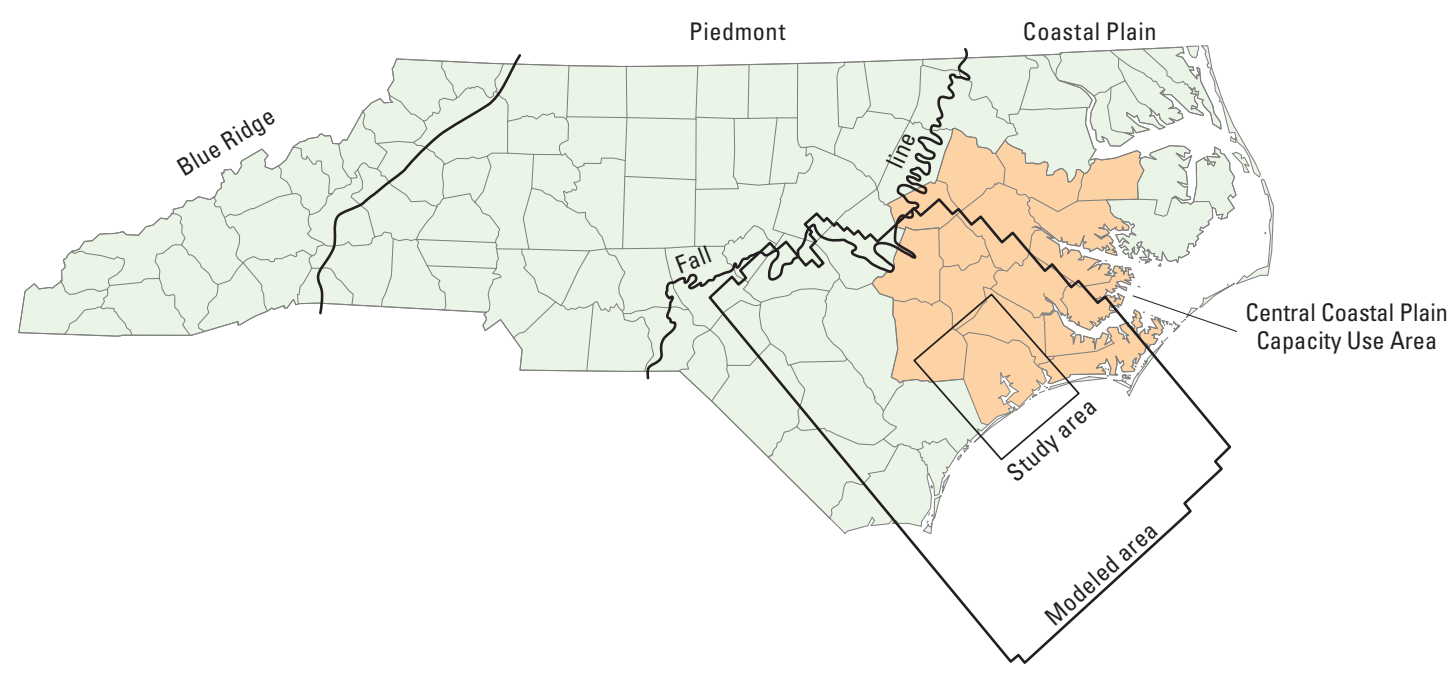

Location of study area, modeled area, and physiographic provinces in North Carolina.

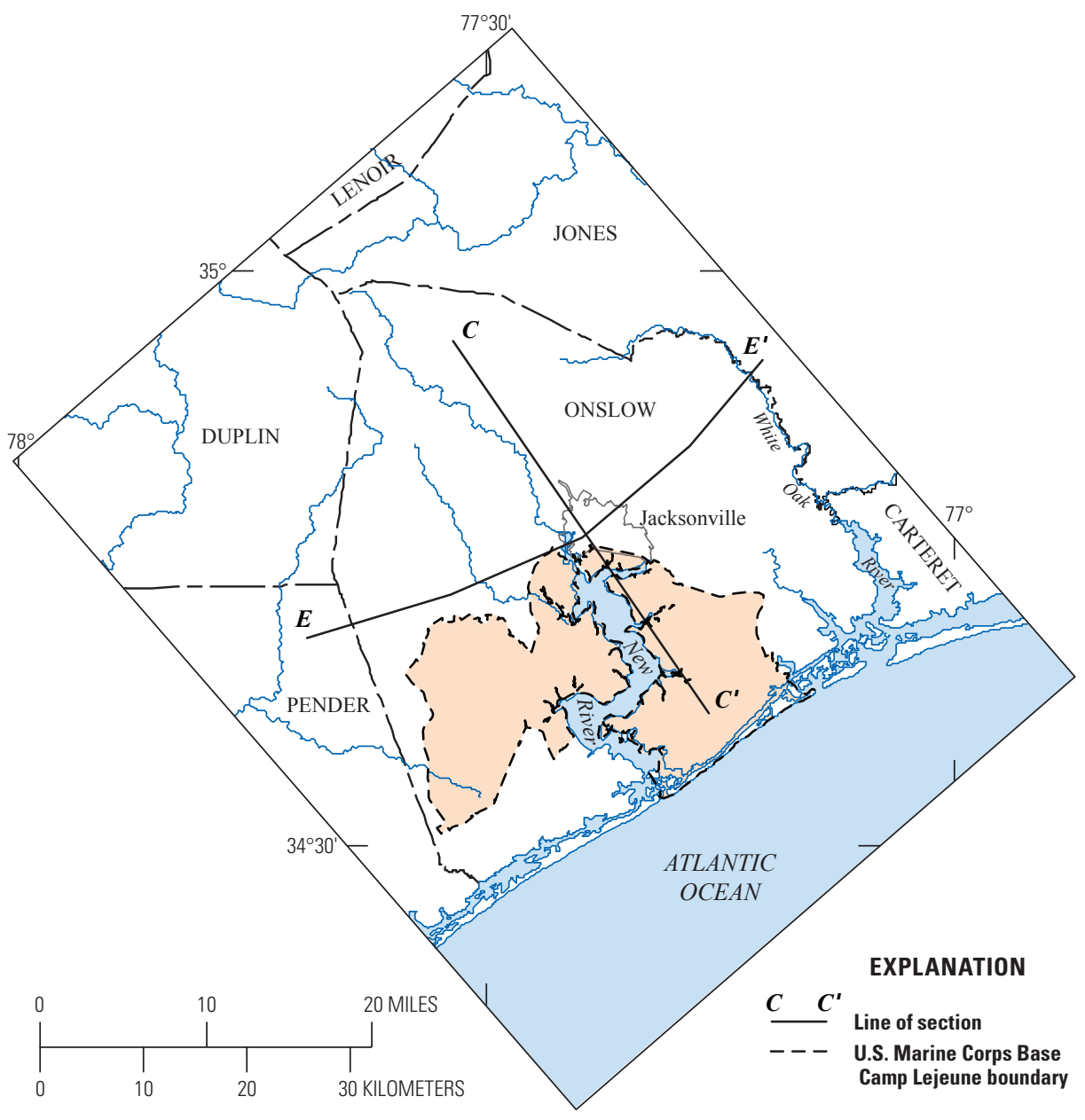

Figure 1. Location of the study area, Onslow County, North Carolina. 


\begin{tabular}{|c|c|c|}
\hline System $^{1}$ & Geologic units & Hydrogeologic units \\
\hline \multirow[t]{5}{*}{ Quaternary } & Quaternary deposits & Surficial aquifer \\
\hline & Yorktown Formation ${ }^{2}$ & $\begin{array}{l}\text { Yorktown confining unit }{ }^{2} \\
\text { Yorktown aquifer }^{2}\end{array}$ \\
\hline & Eastover Formation $^{2}$ & Pungo River confining unit ${ }^{2}$ \\
\hline & Pungo River Formation ${ }^{2}$ & Pungo River aquifer ${ }^{2}$ \\
\hline & Belgrade Formation & \multirow{3}{*}{$\begin{array}{l}\text { Upper Castle Hayne confining unit } \\
\text { Upper Castle Hayne aquifer } \\
\text { Lower Castle Hayne confining unit } \\
\text { Lower Castle Hayne aquifer }\end{array}$} \\
\hline \multirow[t]{3}{*}{ Tertiary } & River Bend Formation & \\
\hline & Castle Hayne Limestone & \\
\hline & Beaufort Formation & $\begin{array}{l}\text { Beaufort confining unit } \\
\text { Beaufort aquifer }\end{array}$ \\
\hline \multirow{5}{*}{ Cretaceous } & Peedee Formation & $\begin{array}{l}\text { Peedee confining unit } \\
\text { Peedee aquifer }\end{array}$ \\
\hline & Black Creek Formation & \multirow{2}{*}{$\begin{array}{l}\text { Black Creek confining unit } \\
\text { Black Creek aquifer }\end{array}$} \\
\hline & Middendorf Formation ${ }^{2}$ & \\
\hline & Cape Fear Formation & $\begin{array}{l}\text { Upper Cape Fear confining unit } \\
\text { Upper Cape Fear aquifer } \\
\text { Lower Cape Fear confining unit } \\
\text { Lower Cape Fear aquifer }\end{array}$ \\
\hline & Unnamed units $^{2}$ & $\begin{array}{l}\text { Lower Cretaceous confining unit }{ }^{2} \\
\text { Lower Cretaceous aquifer }^{2}\end{array}$ \\
\hline
\end{tabular}

${ }^{1}$ System identification of a given hydrogeologic unit is only approximate and reflects the age or ages of the principal geologic unit or units composing each hydrogeologic unit. ${ }^{2}$ Unit not present in the study area.

Figure 2. Correlation chart of North Carolina Coastal Plain geologic and hydrogeologic units (modified from Lyke and Winner, 1990).

and sand, with minor amounts of clay. For this study, the Castle Hayne aquifer has been informally subdivided into two aquifers, the upper and lower Castle Hayne, to better represent head differences that exist in the aquifer. The Castle Hayne aquifer was also subdivided in studies by Harned and others (1989) and Faye and Valenzuela (2007). The confining units, or clay layers, that subdivide the Castle Hayne aquifer are discontinuous and leaky; however, in Onslow County the two "subaquifers" have distinct head differences of as much as $8 \mathrm{ft}$ in the northern part of Camp Lejeune. The Castle Hayne aquifer is used predominantly for water supply in Onslow County and will be a main source for future development with the reduction of use in the Cretaceous aquifers in the area from the CCPCUA.
The Beaufort aquifer consists of Tertiary-age marine sediments and rocks of the Beaufort Formation (fig. 2) that is described by Lyke and Winner (1990) (fig. 2) as being composed of fine to medium glauconitic sand, clayey sand, shell and limestone, and interbedded clay. Most of the study area is underlain by the Beaufort aquifer, with the exception of the western edge of Onslow County where the aquifer pinches out (fig. 3A). The Beaufort confining unit separates the Castle Hayne aquifer from the Beaufort aquifer. The Beaufort aquifer is relatively unproductive and has poor water quality; therefore, it is not used in Onslow County.

The Peedee aquifer consists of sediments of the Peedee Formation (fig. 2), which is the youngest Cretaceous formation in the study area (fig. 2). The Peedee Formation is composed 
primarily of sand with interbedded clay and silt layers, but limestone and partially consolidated calcareous sandstone are layered within the sands of the aquifer in some areas (Lyke and Winner, 1990). The Peedee confining unit separates the overlying aquifers from the Peedee aquifer (fig. 3). Because of high levels of iron and the presence of saltwater near the coast, the Peedee aquifer is used for water supply only in the northern part of Onslow County.

The Black Creek aquifer is composed of the Black Creek and Middendorf Formations of Cretaceous age (fig. 2; Winner and Coble, 1996); however, the Middendorf Formation is not present in the study area. The Black Creek Formation is composed of interbedded sand and clay layers that contain shells, glauconite, and large amounts of organic matter (Lyke and Winner, 1990). The Black Creek confining unit separates the Peedee aquifer from the Black Creek aquifer (fig. 3). The Black Creek aquifer is a source of good quality drinking water in the northern part of the study area, but the presence of saltwater near the coast prevents the aquifer from being used for water supply in the southern half of Onslow County.

The deepest aquifers in the study area are the Upper and Lower Cape Fear aquifers. These aquifers are composed of sand with minor amounts of clay, gravel, and limestone of the Cape Fear Formation of Cretaceous age (fig. 2). The Upper Cape Fear confining unit separates the Upper Cape Fear aquifer from the Black Creek aquifer, and the Lower Cape Fear confining unit separates the Upper Cape Fear aquifer from the Lower Cape Fear aquifer. The Lower Cape Fear aquifer is underlain by crystalline bedrock (basement, fig. 3). The Upper and Lower Cape Fear aquifers are not used in the study area because of their depth and the presence of saltwater.

\section{Groundwater Flow}

Predevelopment groundwater flow within the Atlantic Coastal Plain was largely controlled by the topography (high inland to low at the coast), coastal thickening of the wedge of sediments, recharge on the uppermost part of the system through the surficial aquifer, the location and elevation of streams that incise the Coastal Plain serving as discharge locations, and the location of the freshwater/saltwater interface. Local groundwater flow moves from the upland hills toward the coast and incised streams (similar to surface runoff arrows shown on the block diagram in figure 4). The effect of the incised streams on groundwater flow decreases with the depth of the aquifer. Regional groundwater flow is from the updip (outcrop) areas for the confined aquifers near the Fall Line (fig. 1) toward the downdip area at the coast (fig. 4).
The location of the freshwater/saltwater interface within each aquifer forms a large density contrast in which lighter freshwater flows upward and laterally above the saltwater zone, toward discharge areas in adjacent aquifers or the seabed and is commonly treated as the lateral extent of the freshwater aquifer along the coast (Reilly, 2001; Campbell and Coes, 2010). The location of the pre-development freshwater/saltwater interface in each aquifer was dependent predominantly on the predevelopment pressure, which forms a counter balance to the pressure of the denser seawater once equilibrium has been reached (Badon-Ghijben, 1888; Herzberg, 1901).

The potentiometric surface of the surficial aquifer follows the topography, and depth to the water-table surface can be estimated from land surface data (Harden and others, 2004; Kuniansky and others, 2009). The location of the freshwater/ saltwater interface in the surficial aquifer is near the shoreline as the water level approaches mean sea level (approximately zero elevation). In the updip part of the Coastal Plain, the surficial aquifer can extend almost to bedrock. Thus, water that recharges the surficial aquifer, through infiltration at land surface near the Fall Line, moves downward into deeper aquifers, laterally toward incised streams, and downdip toward the coast and coastal wetlands.

Predevelopment potentiometric surfaces have been estimated for the deeper aquifers in the eastern United States, and all estimates generally indicate groundwater movement toward the coast (Winner and Coble, 1996; and Campbell and Coes, 2010). Additionally, the location of the freshwater/seawater interface was determined in previous studies in North Carolina and South Carolina and was used as the extent of each aquifer (model boundary for calibration of freshwater model) (Campbell and Coes, 2010). In general, these potentiometric maps indicate that predevelopment groundwater flow in the deeper confined aquifers is mainly from inland to the coast with some movement toward the more deeply incised streams.

Long-term groundwater development in the study area since the 1960s, largely in the Castle Hayne, Peedee, Black Creek, and Cape Fear aquifers, has resulted in water-level declines as great as $200 \mathrm{ft}$, creating localized cones of depression (North Carolina Division of Water Resources, 2013a). Thus, regional groundwater flow that would have discharged off shore is now intercepted in areas of heavy and continued groundwater use, thereby reducing upgradient hydraulic pressure. Gradients have reversed near the coast, indicating that groundwater may be moving from offshore toward these cones of depression (DePaul and others, 2008). 
$\boldsymbol{A}$

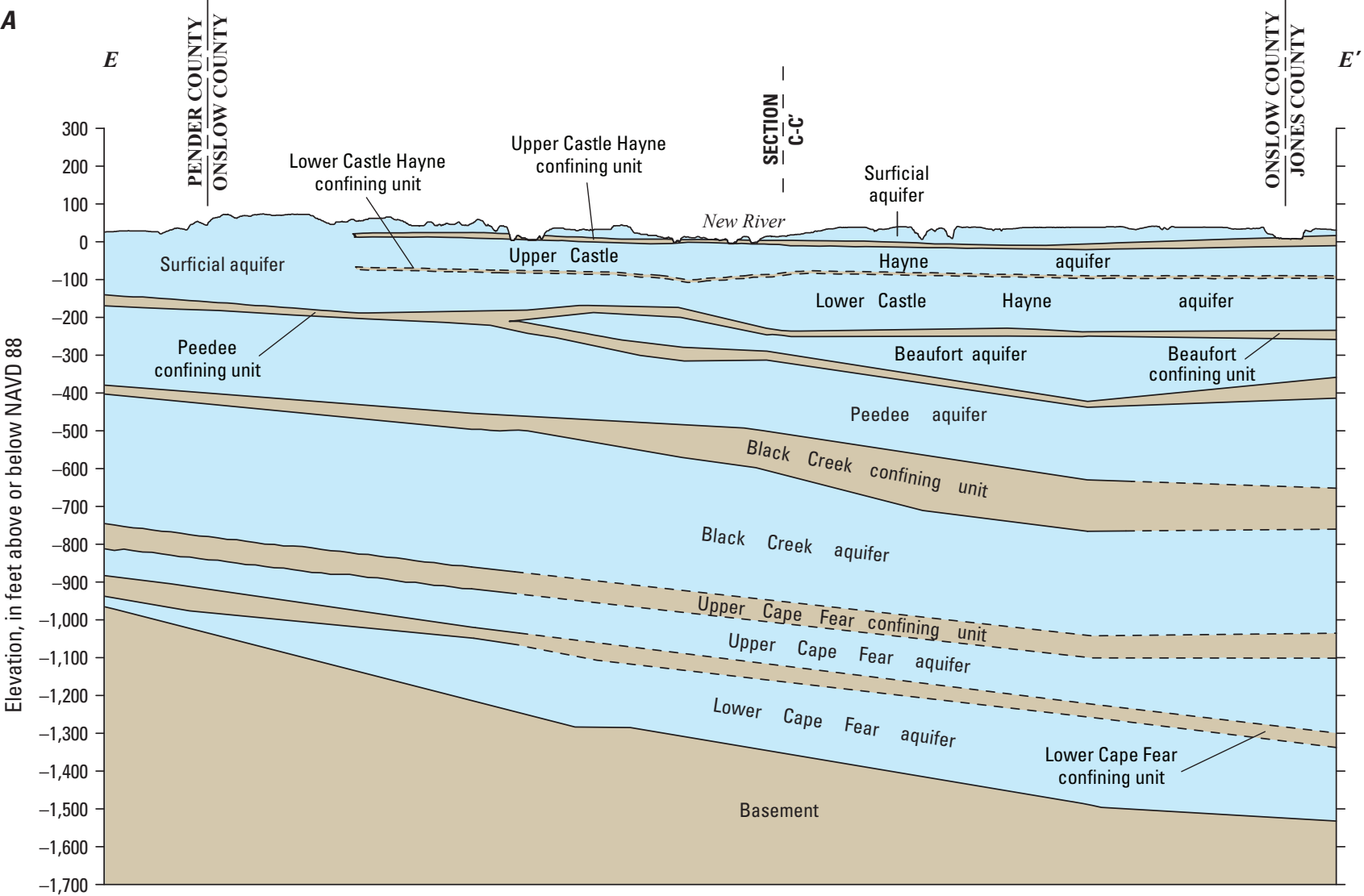

$C$
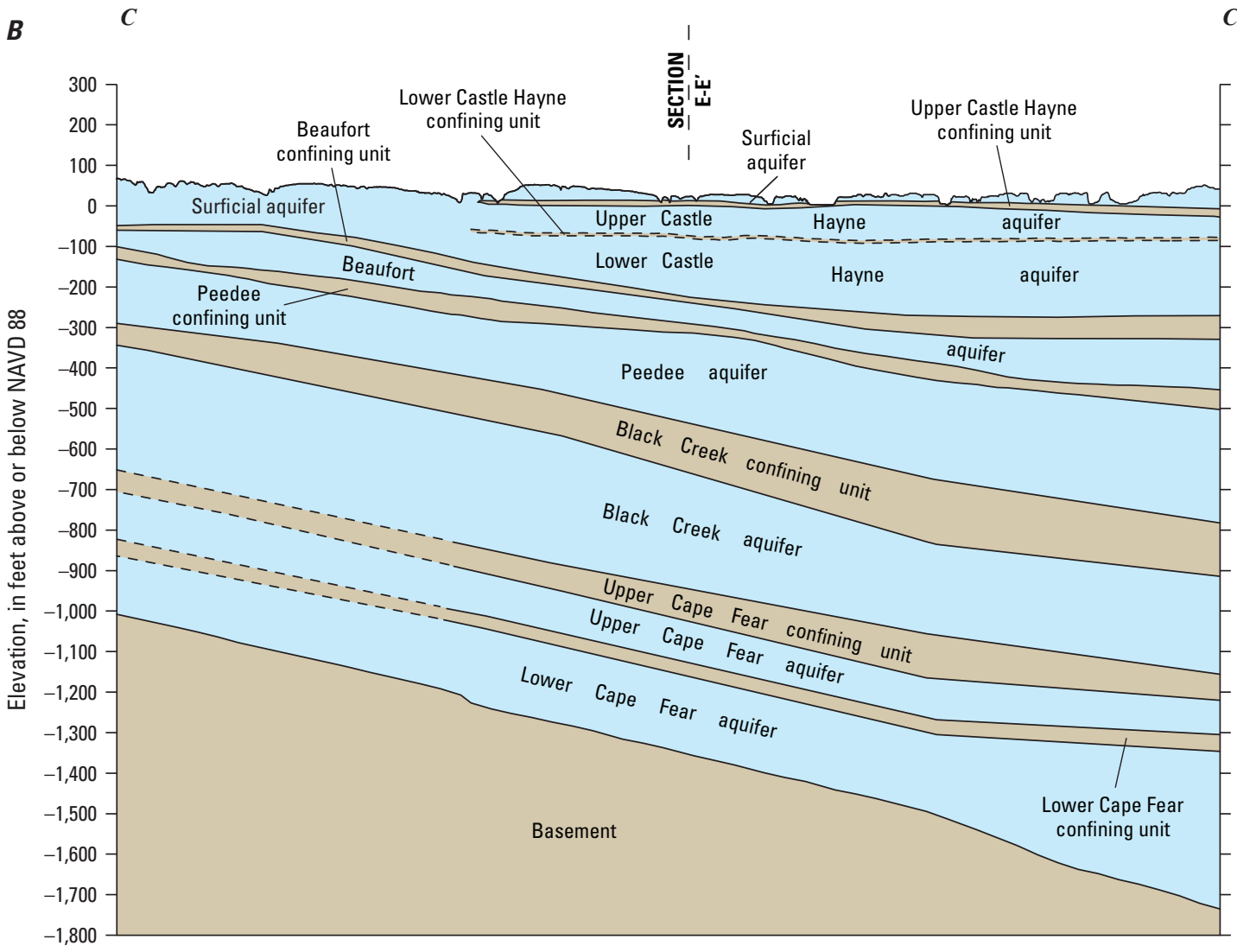

Figure 3. ( $A)$ Cross section $E-E^{\prime}$ showing hydrogeologic strike and $(B)$ cross section $C-C^{\prime}$ 'showing hydrogeologic dip in the study area (modified from Fine, 2008). 


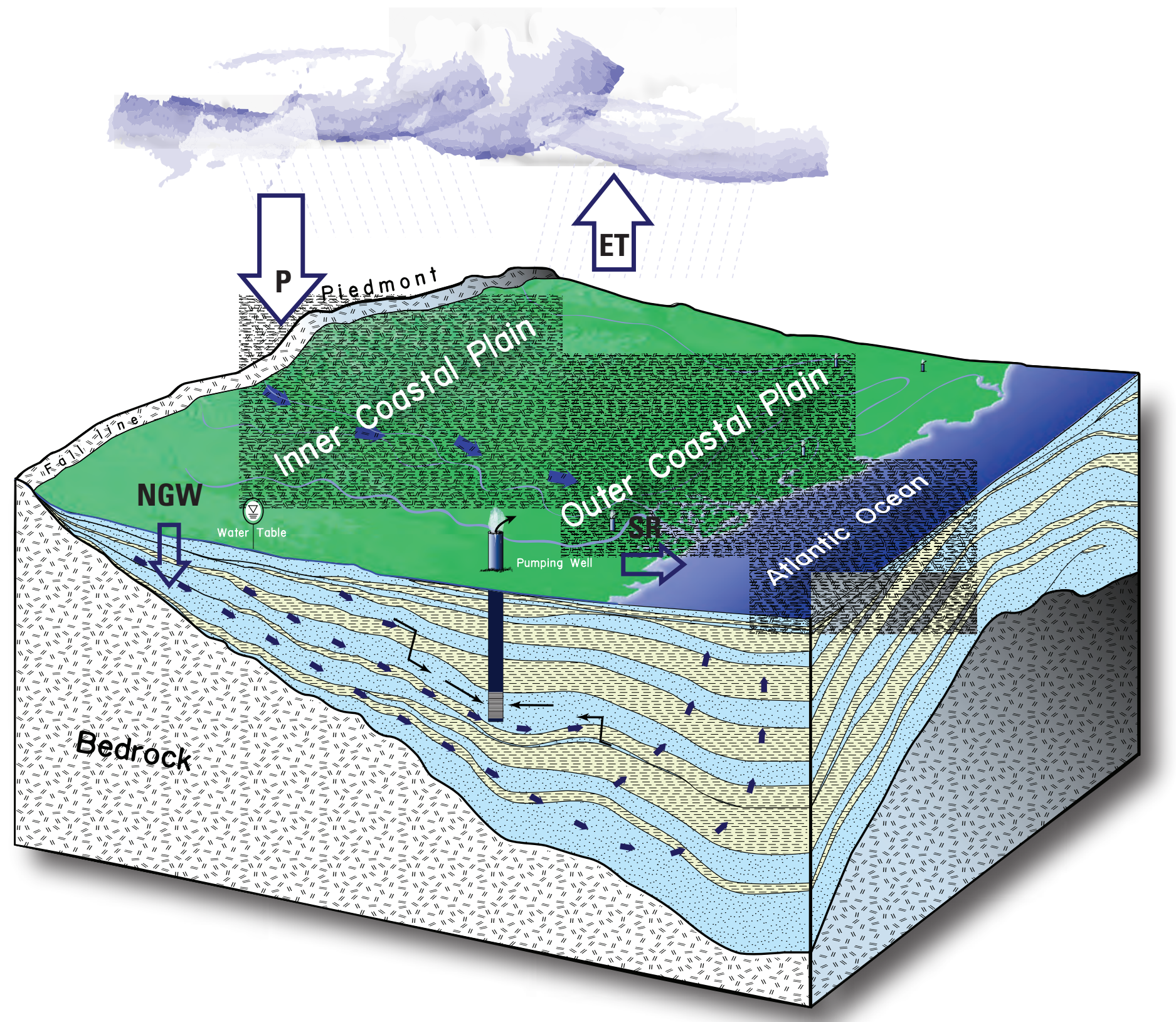

EXPLANATION

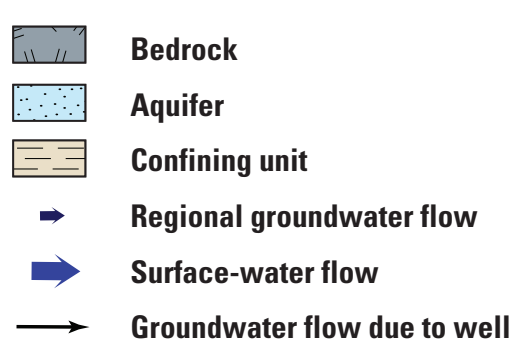

Figure 4. Generalized block diagram of the aquifers and confining units of the Atlantic Coastal Plain of North and South Carolina showing generalized directions of flow for surface runoff and regional groundwater flow (modified from Campbell and Coes, 2010). 


\section{Groundwater Pumpage}

The Castle Hayne and Black Creek aquifers are the principle sources of groundwater supply in the Onslow County, North Carolina, study area. In late 1930s, Camp Lejeune became the first water user in the study area to withdraw large amounts of groundwater. Since then, groundwater use has steadily increased as population has increased (fig. 5). The model area includes rural counties in which, livestock, irrigation, and domestic withdrawals account for a large percentage of total pumpage. The increase in total withdrawals in 1985 was due to the availability of estimates of livestock, irrigation, and domestic withdrawal data. These data are based on estimates of groundwater pumpage by county that are available every 5 years beginning in 1985 (U.S. Geological Survey, 2013a). The data for livestock, irrigation, and domestic withdrawals were not available prior to 1985 .

As aquifer withdrawals have increased, groundwater levels have steadily declined in the Cretaceous aquifers of the central Coastal Plain (fig. 1). Because of these declines and the resulting increased potential for lateral saltwater migration along the coast and upward leakage of brackish water from deeper aquifers, the NCDWR instituted the CCPCUA rules for 15 counties, effective August 1, 2002 (North Carolina Division of Water Resources, 2013a). Under the CCPCUA rules, groundwater withdrawals of more than 100,000 gallons per day per well from any of the Cretaceous aquifer systems are subject to a water-use reduction of as much as 75 percent over a 16-year period. As part of the 15-county CCPCUA area, groundwater users in the Onslow County study area that withdraw from the Cretaceous aquifers are subject to the CCPCUA rules.
To comply with the CCPCUA reductions, water suppliers in the study area are developing alternative sources of water. One of the most prevalent new sources of groundwater being developed is the Castle Hayne aquifer. The Castle Hayne aquifer has the potential to supply large amounts of water; however, its close proximity to the Atlantic Ocean in the study area increases the potential for movement of saltwater into the aquifer.

\section{Groundwater Recharge}

Groundwater recharge is the water that enters the saturated zone of an aquifer. For a water-table aquifer, recharge generally occurs during and following rainfall events. For water-supply planning and groundwater modeling, an estimate of the "net" groundwater recharge in an area is required. Net groundwater recharge is groundwater recharge minus evaporation and transpiration (evapotranspiration) and is commonly estimated from precipitation minus surface runoff and evapotranspiration. Evapotranspiration is a somewhat continuous process and is largely driven by heat energy and daylight hours. Estimates of net groundwater recharge are approximate because the value is a relatively small component of the hydrologic cycle and often within the error of components that can be measured or estimated, such as precipitation and evapotranspiration. However, net groundwater recharge is often the largest component of the groundwater system water budget. Estimates of net groundwater recharge rely on multiple methods (Coes and others, 2007; Healy, 2010). In the southeastern United States, combinations of climatic water budget methods and use of streamflow information are applied frequently to estimate net groundwater recharge. Additionally, in many reports the term groundwater recharge is used when the actual intention of the author is net groundwater recharge.

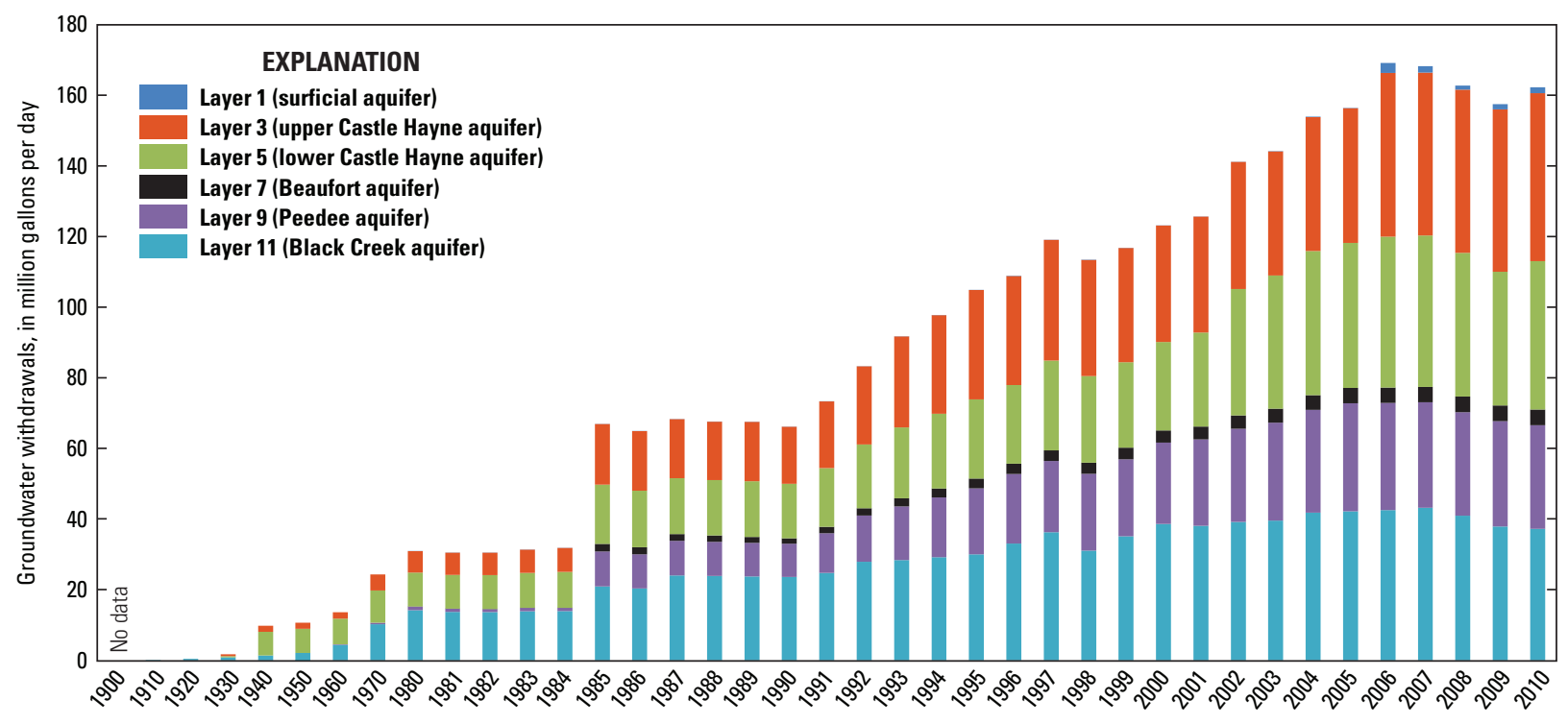

Figure 5. Groundwater use by aquifer in wells in the model area (from North Carolina Division of Water Resources (2013a and b) and U.S. Geological Survey, 2013b). 
Climatic water budgets are used to constrain the estimate of net groundwater recharge in that these tools help estimate evapotranspiration and require different datasets depending on the method applied. One of the most commonly applied climatic water budget methods used in the eastern United States is called the Thornthwaite water budget (Thornthwaite, 1948; Thornthwaite and Mather, 1955; Thornthwaite and Mather, 1957; Muller and Larimore, 1975; Muller and Thompson, 1987) or the Thornthwaite-Mather soil water budget (Westenbroek and others, 2010). The Thornthwaite water budget is an empirically derived climatic water budget that is based on mean monthly temperature and precipitation data from a climatic station. The method uses the latitude of the climate station for the estimate of daylight hours and longterm (generally 30 -year average) mean monthly temperature to develop a heat index for the estimation of evapotranspiration. Monthly continuous water budget software that uses this method was developed by McCabe and others (1985) and later converted to a spreadsheet (Roberto Anaya, U.S. Geological Survey, written commun., 1997, and modified by Eve Kuniansky and Connor Haugh, U.S. Geological Survey, written commun., 2000, to allow for entering a percentage split of the surplus into monthly surface runoff and base flow). Additional information required for the Thornthwaite monthly water budget at each climate station is the soil moisture storage capacity (a fixed value) and the antecedent soil moisture storage condition (the amount in storage from the preceding month); these data are for the site and are not provided at climate stations. Essentially, the Thornthwaite water budget estimates potential evapotranspiration from temperature and daylight hours based on a set of empirical equations. The empirical equations were based on water use in irrigation districts in the United States and evapostranspirometer data (Thornthwaite and Mather, 1957). However, potential evapotranspiration is the maximum evapotranspiration that could occur if water is available from the soil storage capacity and precipitation. When water is not fully available to meet potential evapotranspiration, actual evapotranspiration is calculated in the Thornthwaite budget based on the current month precipitation, temperature, and previous month soil moisture storage data. No distinction is made for separation of soil and surface evaporation from plant transpiration. If precipitation exceeds potential evapotranspiration and the soil moisture storage is full from a previous month, there will be a surplus of water available for both surface runoff and groundwater recharge. The Thornthwaite water budget approach is an accounting method that is commonly applied toward developing reasonable estimates of the water surplus available for surface runoff and net groundwater recharge given readily available monthly climatic data (Kuniansky, 1989; Haugh, 2002; Westenbroek and others, 2010).

The components from the Thornthwaite monthly continuous water budget are shown in figure 6 for the long-term average monthly temperature and precipitation data for the Maysville, North Carolina, climate station in Onslow County (1950-81; station name NC-ON-40, http://nc-climate.ncsu.edu/cronos/index.php). Because the

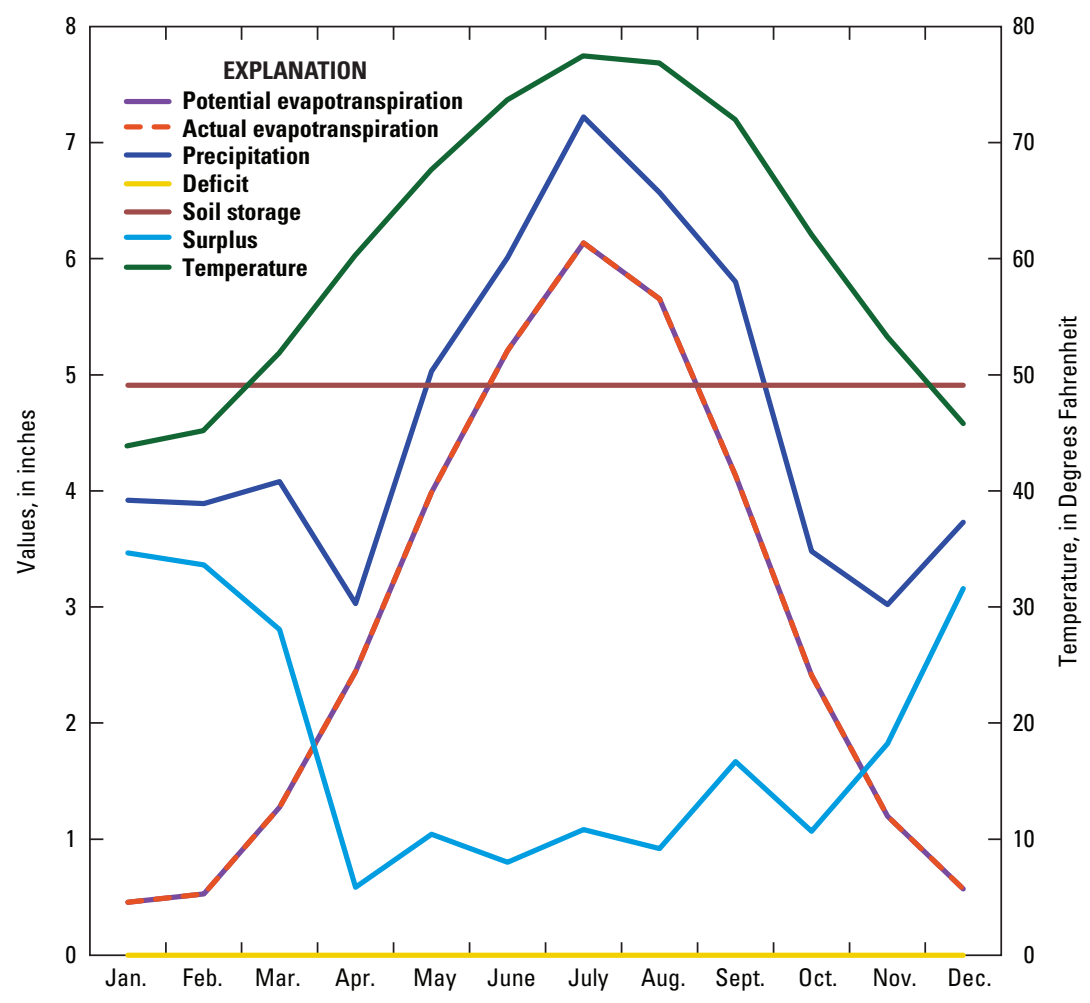

Figure 6. Long-term mean monthly Thornthwaite water budget for Maysville, North Carolina. 
water budget begins in January, it is assumed that the soil moisture was at the field capacity of approximately 5 inches, as potential evapotranspiration is smallest in the winter and precipitation tends to exceed potential evapotranspiration in November and December. Long-term average data for this station (1950-81) indicate that although there generally is rainfall year round, higher amounts of rainfall occur in the summer months when evapotranspiration is greatest, thus with long-term average data (1951-80) there are no soil deficits and actual evapotranspiration always equals potential evapotranspiration. Based on long-term average climatic data and the water budget at this station, annual average precipitation is 56 inches, annual average evapotranspiration is 34 inches, and annual average surplus is 22 inches.

Long-term average streamflow in a watershed that is undeveloped and has no reservoirs, surface-water intakes, or sewage outfalls, can provide an estimate of precipitation minus evapotranspiration (the Thornthwaite surplus) because the total streamflow represents both surface runoff and groundwater discharge. (Note: Deeper recharge is assumed to be small.) Krug and others (1990) contoured mean annual streamflow for this same period of time and location to be 18 to 20 inches annually, which is comparable to the Thornthwaite water budget surplus with the soil moisture storage capacity set at about 5 inches. For the purpose of developing an initial estimate of net groundwater recharge, the soil storage capacity was kept at about 5 inches for all stations as this produces a surplus approximately equal to the total streamflow estimated from the streamflow contour map.

The long-term mean monthly data are useful for understanding average seasonality in the area and estimating a soil storage capacity for the area. The long-term mean budget (fig. 6), however, is somewhat deceiving in that some of the components of the water budget, such as precipitation, are much more variable for any given month. The water budget for the Maysville, North Carolina station for 1980-2010 shows the variability in rainfall between months and how this variability affects other water budget components (fig. 7). Potential evapotranspiration is still a fairly smooth function that rises to a peak in the summer; actual evapotranspiration begins to drop below potential evapotranspiration as soil moisture becomes depleted through the summer, but then becomes equal to potential evapotranspiration in the fall and winter when the growing season, temperature, and daylight hours are less than in the summer. Figures 6 and 7 illustrate the reasons why a percentage of precipitation could be used as an estimate of net groundwater recharge for annual periods, but should not be used for seasonal estimates.

The Thornthwaite water budget alone does not provide an estimate of net groundwater recharge. Kuniansky (1989) used the Thornthwaite water budget along with hydrograph separation and flow duration statistics to separate the calculated surplus into surface runoff and groundwater recharge components. Haugh (2002) used the stream base-flow index (base flow divided by total streamflow) of 53 percent of the surplus from the Thornthwaite water budget as his estimate of net groundwater recharge and compared this to other methods for locations in Tennessee. For Tennessee, the Thornthwaite method provided a more conservative estimate of evapotranspiration and thus potentially overestimated net groundwater recharge (Haugh, 2002). Westenbroek and others (2010) developed a data-intensive geographic information system (GIS) approach that modifies the Thornthwaite and Mather (1957) water budget accounting method and incorporates the U.S. Department of Agriculture, Natural Resources Conservation Service (NRCS) curve number method (Cronshey and others, 1986) for computing surface runoff to separate the surplus into runoff and net groundwater recharge, but requires both climatic data and detailed topographic, land use, and soils spatial information.

Base flow of a stream is often used as an estimate of net groundwater recharge because base flow is an estimate of groundwater discharge (Sloto and Crouse, 1996; Daniel and Harned, 1998; Rutledge, 1998). Hydrograph separation methods without the benefit of additional chemical methods are found to be within a factor of 2 of the estimate of base flow (Kinzelbach and others, 2002; Stewart and others, 2007). Long-term range in base flow for the southern Coastal Plain of the United States ranged from 2 to 15 inches per year with a base-flow index range of 64 to 87 percent (Campbell and Coes, 2010). The streamgage 02093000 on the New River near Gum Branch, North Carolina, in Onslow County has a drainage area of $94 \mathrm{mi}^{2}$. The flow duration curve for this station, however, does not approach a limiting value (asymptotic), and the terrain is fairly flat; thus, it is not an ideal site for hydrograph separation (fig. 8). Rather than use hydrograph separation methods to estimate long-term base flow at the local surface-water station, the flow value range that was exceeded between 50 to 90 percent of the time -2 to 8 inches per year for the period (1949-2009) — was used to bracket a long-term estimate of net groundwater recharge. Flow exceeded 90 percent the low conservative estimate (lower flow) and flow exceeded 50 percent of the time greater than the flow duration statistic that matched hydrograph separation for the southeastern United States of between 60 to 65 percent of the time (Stricker, 1983; Kuniansky,1989). Thus, using the streamgage in the study area, the equivalent percent of the Thornthwaite water budget surplus that is net groundwater recharge based on long-term flow duration data ranges from 9 to 36 percent.

Within the study area, eight climatic stations that had monthly precipitation and temperature data from 1980 through 2010 were used to estimate net groundwater recharge on a monthly basis and for developing an annual estimate for periods before 1980 (table 1; fig. 1). Monthly water budgets were developed from 1980 through 2010 for all eight sites (5 inches was used as the soil moisture storage capacity for all the stations). The intensity of rainfall during large storm events, such as hurricanes or tropical storms causes runoff resulting in flooding rather than infiltration. The Thornthwaite surplus for a month in which a hurricane occurred was reduced 50 percent prior to the calculation of net groundwater recharge. 


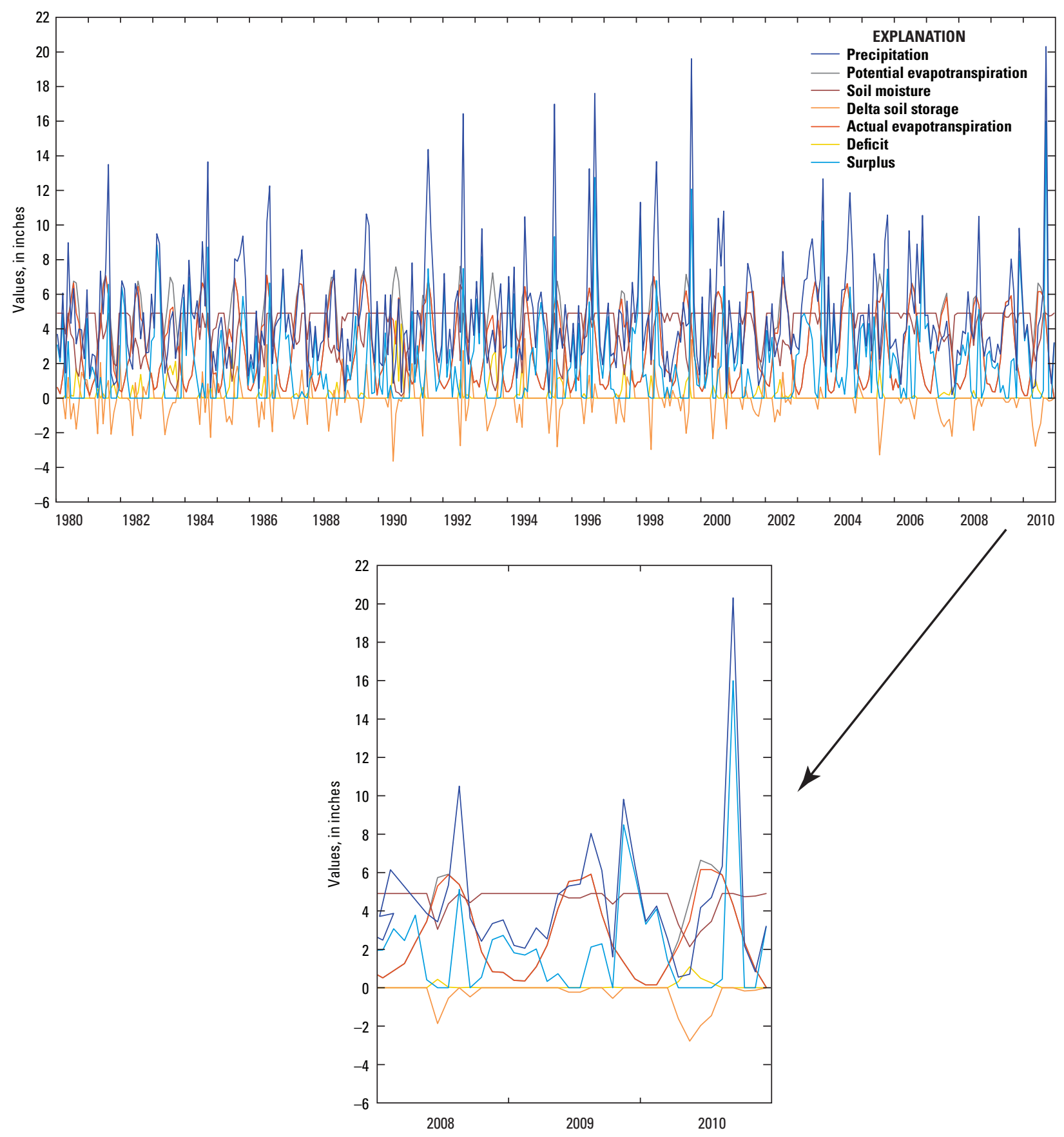

Figure 7. Monthly Thornthwaite water budget for Maysville, North Carolina, climate data 1980-2010. 


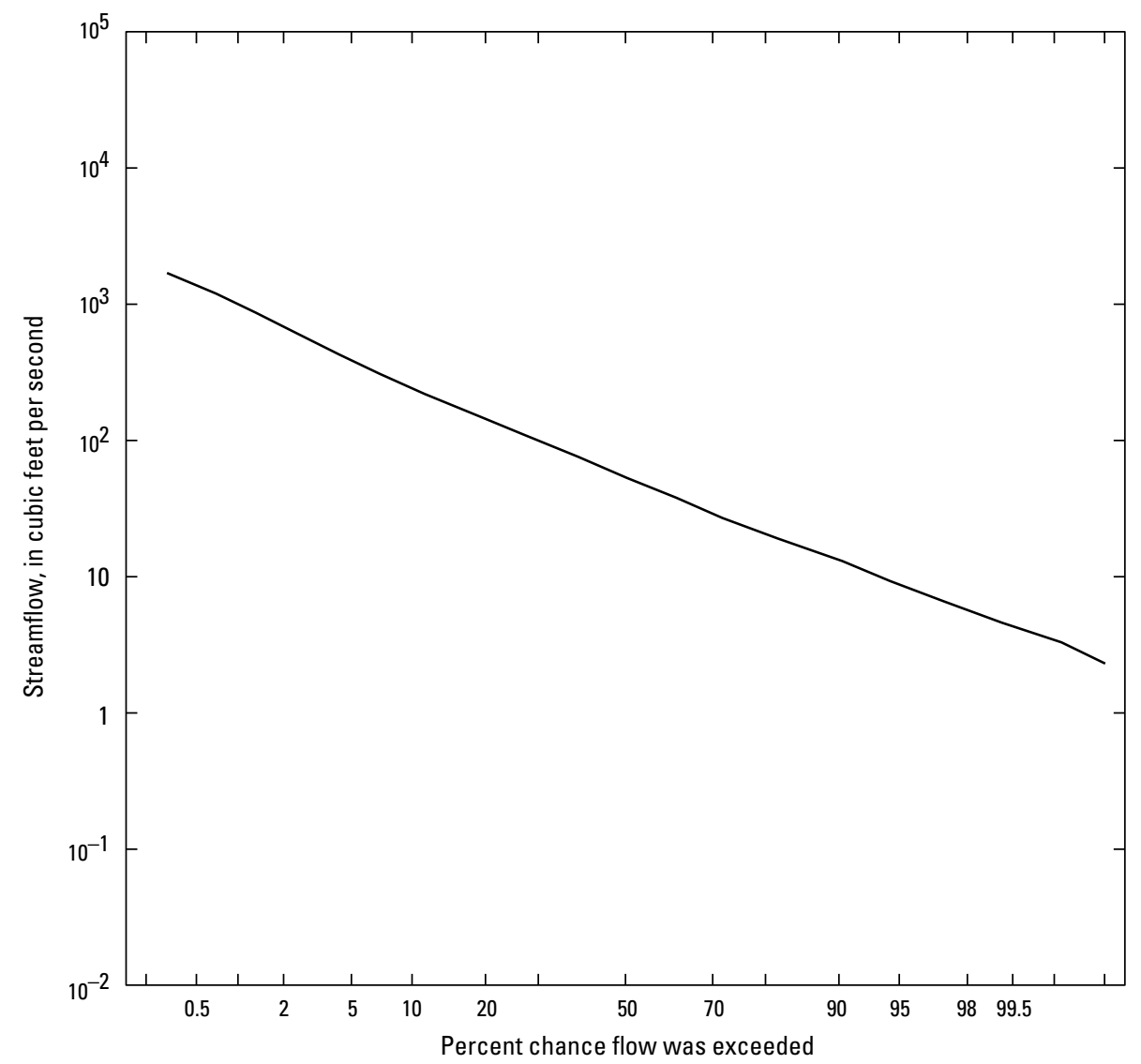

Figure 8. Flow duration curve for the New River near Gum Branch, North Carolina, 1949-2009.

For the initial estimate of net groundwater recharge, a value of 20 percent of the hurricane-adjusted monthly surplus from the Thornthwaite water budget was used. Additionally, to calculate net groundwater recharge for the pre-1980 or decadal stress periods, regression equations were developed on the basis of the annual precipitation from the 1980 to 2010 annual values versus the annual adjusted surplus (regression provided in table 1). The monthly estimated net groundwater recharge (1980-2010) for each station is provided in table 2. The estimated average annual net groundwater recharge ranged from 3 to 5 inches at the eight stations (1980-2010, table 1). The use of a climatic water budget with flow duration statistics provides a consistent method for estimation of net groundwater recharge for either annual periods (pre 1980) or seasonal net groundwater recharge estimates for 1980 to 2010 . These estimates serve as a starting point for constraining the model calibration by providing a reasonable estimate of net groundwater recharge that is adjusted during model calibration. The estimated net groundwater recharge is no more accurate than hydrograph separation estimates. 


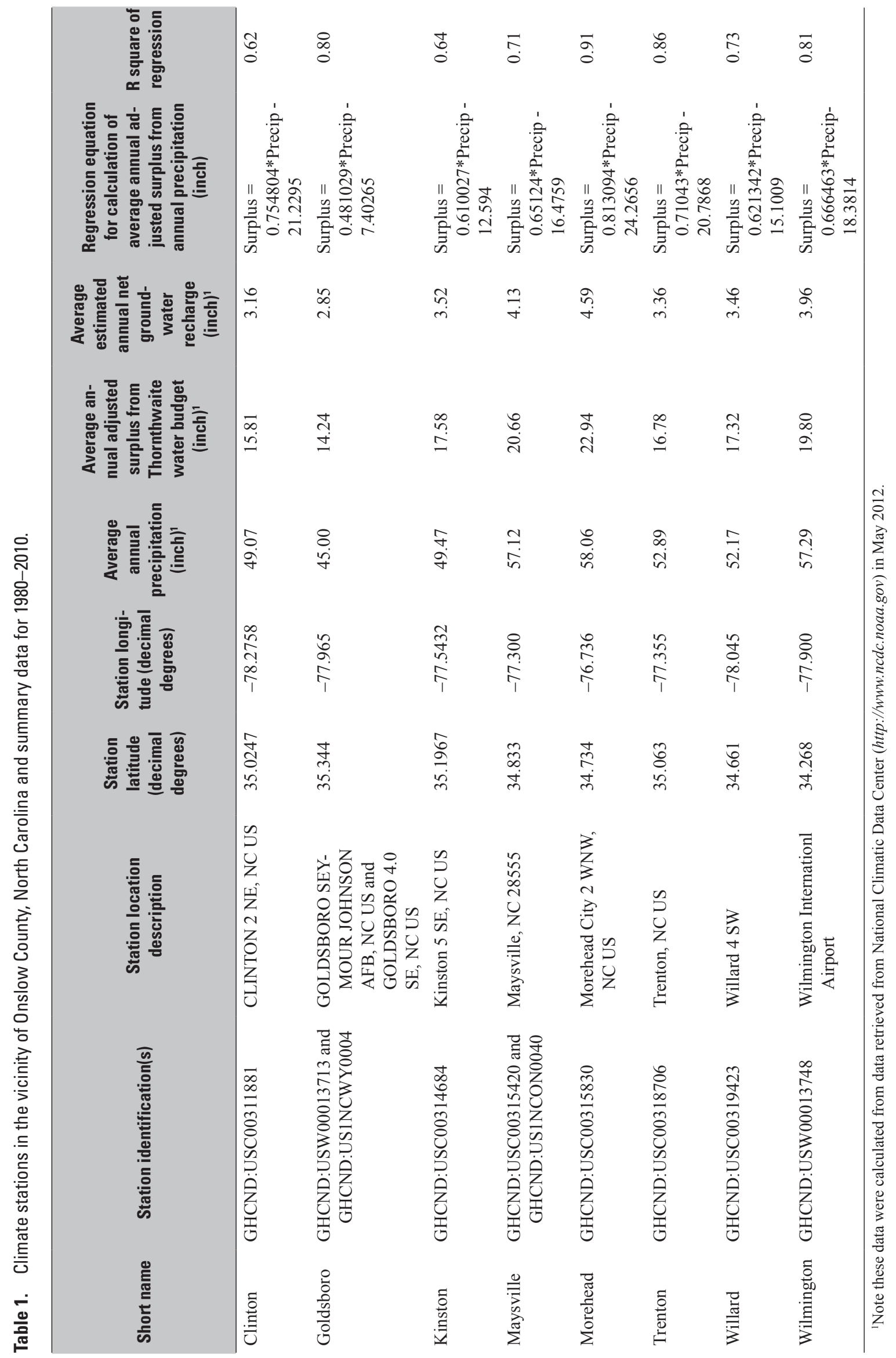


Table 2. Monthly estimated net groundwater recharge at climate sites in the vicinity of Onslow County, North Carolina.

[All units are in inches]

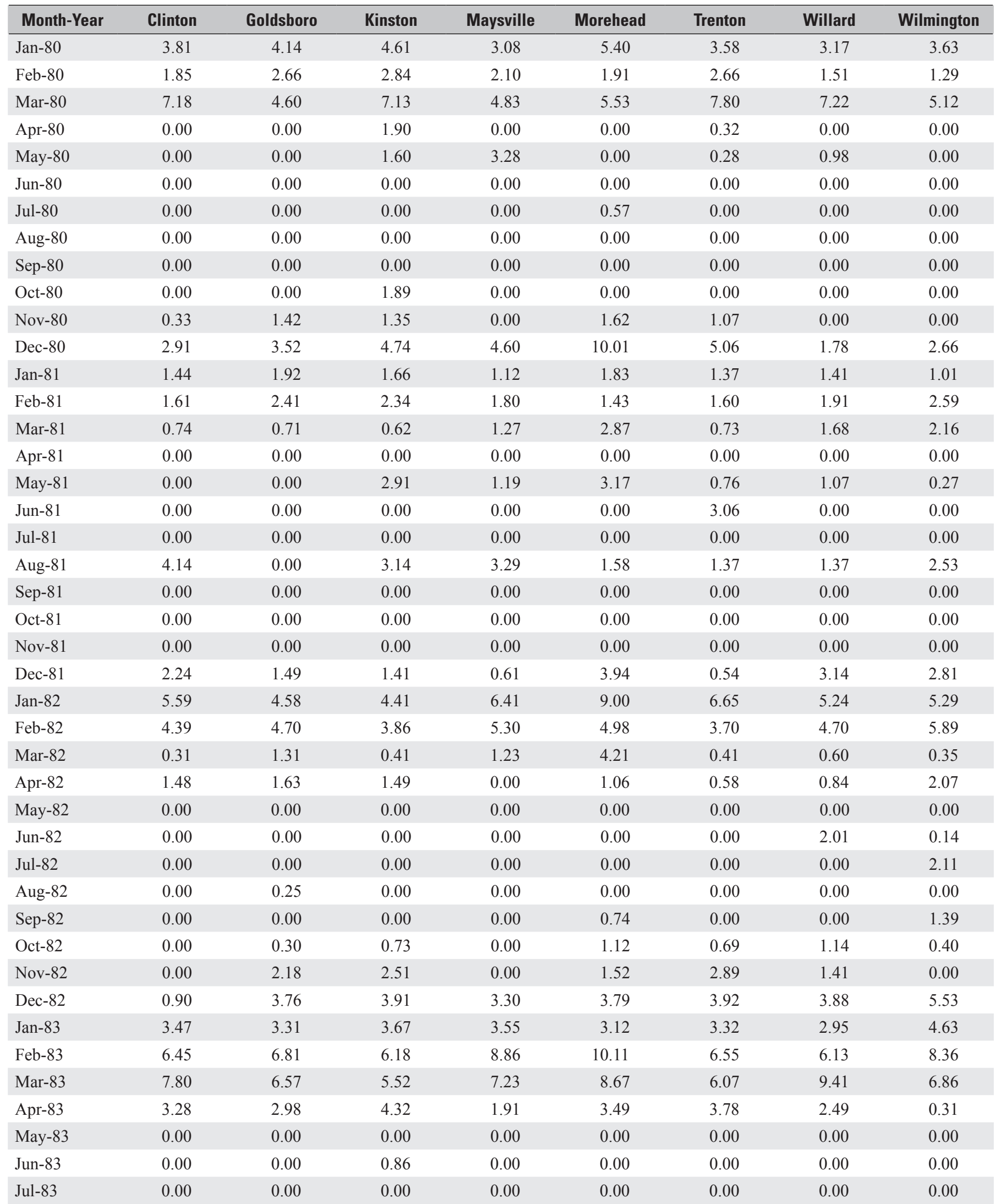


Table 2. Monthly estimated net groundwater recharge at climate sites in the vicinity of Onslow County, North Carolina.-Continued [All units are in inches]

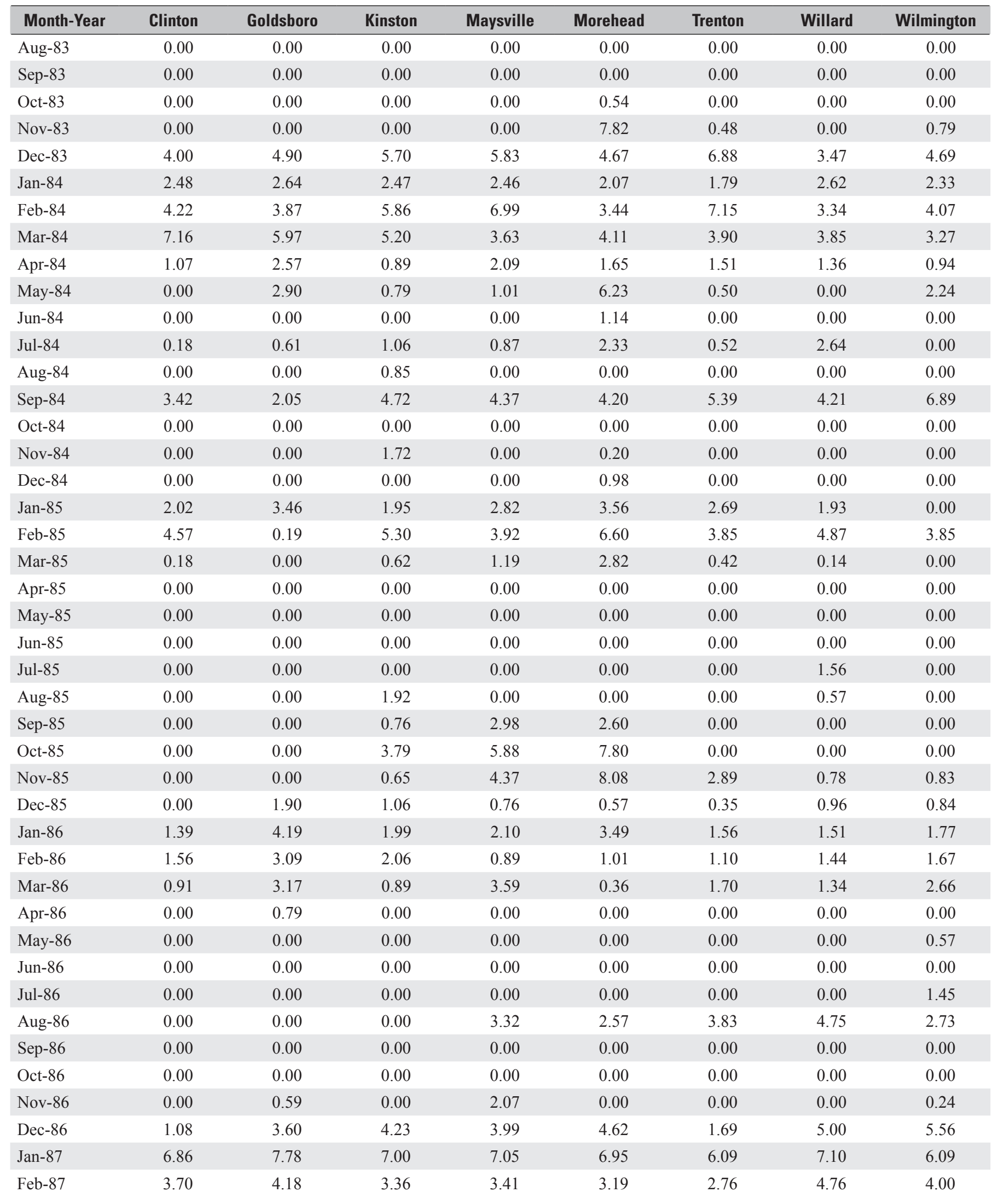


Table 2. Monthly estimated net groundwater recharge at climate sites in the vicinity of Onslow County, North Carolina.—Continued [All units are in inches]

\begin{tabular}{|c|c|c|c|c|c|c|c|c|}
\hline Month-Year & Clinton & Goldsboro & Kinston & Maysville & Morehead & Trenton & Willard & Wilmington \\
\hline Mar-87 & 3.47 & 4.71 & 3.50 & 3.66 & 4.06 & 3.26 & 2.81 & 1.57 \\
\hline Apr-87 & 2.91 & 1.86 & 4.06 & 1.58 & 1.09 & 1.36 & 1.58 & 0.85 \\
\hline May-87 & 0.00 & 0.00 & 0.00 & 0.00 & 0.00 & 0.00 & 0.00 & 0.00 \\
\hline Jun-87 & 0.00 & 0.00 & 0.00 & 0.00 & 0.00 & 0.00 & 0.00 & 0.00 \\
\hline Jul-87 & 0.00 & 0.00 & 0.00 & 0.00 & 0.00 & 0.00 & 0.00 & 0.00 \\
\hline Aug-87 & 0.00 & 0.00 & 0.89 & 0.39 & 0.00 & 0.00 & 1.03 & 0.00 \\
\hline Sep- 87 & 0.00 & 0.00 & 0.12 & 0.09 & 1.45 & 0.00 & 3.07 & 0.64 \\
\hline Oct- 87 & 0.00 & 0.00 & 0.00 & 0.00 & 0.66 & 0.00 & 0.00 & 0.00 \\
\hline Nov-87 & 0.00 & 0.00 & 0.82 & 1.13 & 4.76 & 0.00 & 0.00 & 2.99 \\
\hline Dec-87 & 0.00 & 0.00 & 4.11 & 1.38 & 1.19 & 0.00 & 2.26 & 0.61 \\
\hline Jan- 88 & 2.73 & 2.65 & 3.85 & 3.74 & 7.22 & 2.68 & 3.12 & 5.21 \\
\hline Feb-88 & 1.17 & 0.95 & 1.34 & 1.34 & 3.16 & 0.95 & 1.66 & 1.53 \\
\hline Mar-88 & 0.92 & 1.23 & 1.08 & 1.56 & 1.81 & 1.61 & 1.66 & 2.75 \\
\hline Apr-88 & 0.00 & 0.97 & 1.68 & 0.52 & 2.25 & 0.51 & 1.09 & 1.19 \\
\hline May- 88 & 1.75 & 0.00 & 2.56 & 1.39 & 3.20 & 0.45 & 2.00 & 3.59 \\
\hline Jun- 88 & 0.00 & 0.00 & 0.00 & 0.00 & 0.00 & 0.00 & 0.00 & 0.00 \\
\hline Jul-88 & 1.16 & 0.00 & 0.00 & 0.00 & 0.00 & 0.00 & 1.29 & 2.99 \\
\hline Aug-88 & 0.00 & 0.00 & 0.00 & 0.00 & 1.15 & 0.00 & 0.00 & 3.03 \\
\hline Sep- 88 & 0.00 & 0.00 & 0.00 & 0.00 & 0.00 & 0.00 & 0.00 & 0.00 \\
\hline Oct-88 & 0.00 & 0.00 & 0.00 & 0.00 & 0.00 & 0.00 & 0.79 & 0.00 \\
\hline Nov-88 & 0.00 & 0.00 & 0.22 & 0.00 & 0.82 & 0.00 & 0.36 & 0.25 \\
\hline Dec-88 & 0.19 & 0.00 & 0.34 & 0.00 & 1.00 & 0.00 & 0.09 & 0.10 \\
\hline Jan-89 & 1.93 & 1.57 & 1.87 & 1.91 & 2.80 & 1.50 & 2.26 & 0.69 \\
\hline Feb-89 & 2.89 & 3.32 & 3.38 & 1.08 & 3.16 & 2.41 & 2.30 & 1.86 \\
\hline Mar-89 & 4.73 & 4.46 & 5.26 & 2.61 & 6.56 & 4.11 & 3.77 & 5.26 \\
\hline Apr-89 & 2.12 & 5.32 & 3.25 & 4.73 & 3.80 & 3.31 & 2.44 & 5.26 \\
\hline May-89 & 0.30 & 1.34 & 1.22 & 0.00 & 0.00 & 0.00 & 0.14 & 0.00 \\
\hline Jun-89 & 1.47 & 0.00 & 0.00 & 0.00 & 0.00 & 0.00 & 0.00 & 0.73 \\
\hline Jul-89 & 0.75 & 0.46 & 0.00 & 0.00 & 0.00 & 0.00 & 2.24 & 3.12 \\
\hline Aug-89 & 0.00 & 0.00 & 0.00 & 2.11 & 2.46 & 0.00 & 0.55 & 0.00 \\
\hline Sep-89 & 0.78 & 0.00 & 1.34 & 4.93 & 3.98 & 2.12 & 2.16 & 3.18 \\
\hline Oct-89 & 0.88 & 0.57 & 0.69 & 0.26 & 3.33 & 0.09 & 1.02 & 1.87 \\
\hline Nov-89 & 2.41 & 2.94 & 0.84 & 0.33 & 0.87 & 0.48 & 0.46 & 0.53 \\
\hline Dec-89 & 4.38 & 3.75 & 4.10 & 5.41 & 5.73 & 5.76 & 5.02 & 6.96 \\
\hline Jan-90 & 1.94 & 1.20 & 2.81 & 0.76 & 2.35 & 1.13 & 1.99 & 1.37 \\
\hline Feb-90 & 1.00 & 1.84 & 1.17 & 0.22 & 1.08 & 0.42 & 0.85 & 1.12 \\
\hline Mar-90 & 1.82 & 2.63 & 2.32 & 3.76 & 2.06 & 3.55 & 2.53 & 3.29 \\
\hline Apr-90 & 0.49 & 0.00 & 0.91 & 0.00 & 0.71 & 0.26 & 0.00 & 0.00 \\
\hline May-90 & 0.53 & 3.55 & 1.54 & 0.73 & 1.59 & 2.24 & 1.59 & 3.11 \\
\hline Jun-90 & 0.00 & 0.00 & 0.00 & 0.00 & 0.00 & 0.00 & 0.00 & 0.00 \\
\hline Jul-90 & 0.00 & 0.00 & 0.00 & 0.00 & 0.00 & 0.00 & 0.00 & 0.00 \\
\hline Aug-90 & 0.00 & 0.00 & 0.21 & 0.00 & 0.00 & 1.03 & 0.94 & 1.02 \\
\hline Sep-90 & 0.00 & 0.00 & 0.00 & 0.00 & 0.00 & 0.00 & 0.00 & 0.00 \\
\hline
\end{tabular}


Table 2. Monthly estimated net groundwater recharge at climate sites in the vicinity of Onslow County, North Carolina.-Continued [All units are in inches]

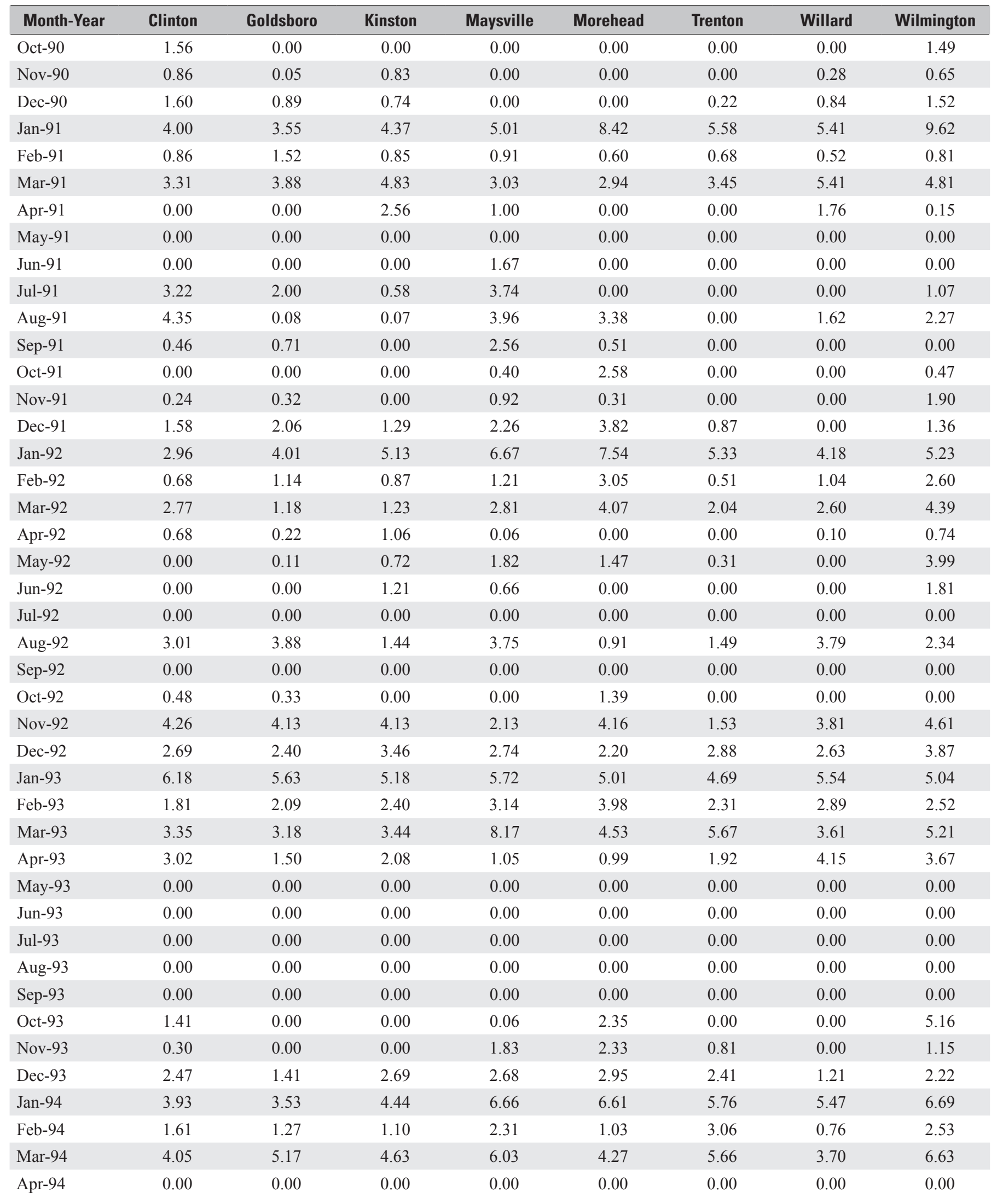


Table 2. Monthly estimated net groundwater recharge at climate sites in the vicinity of Onslow County, North Carolina.-Continued [All units are in inches]

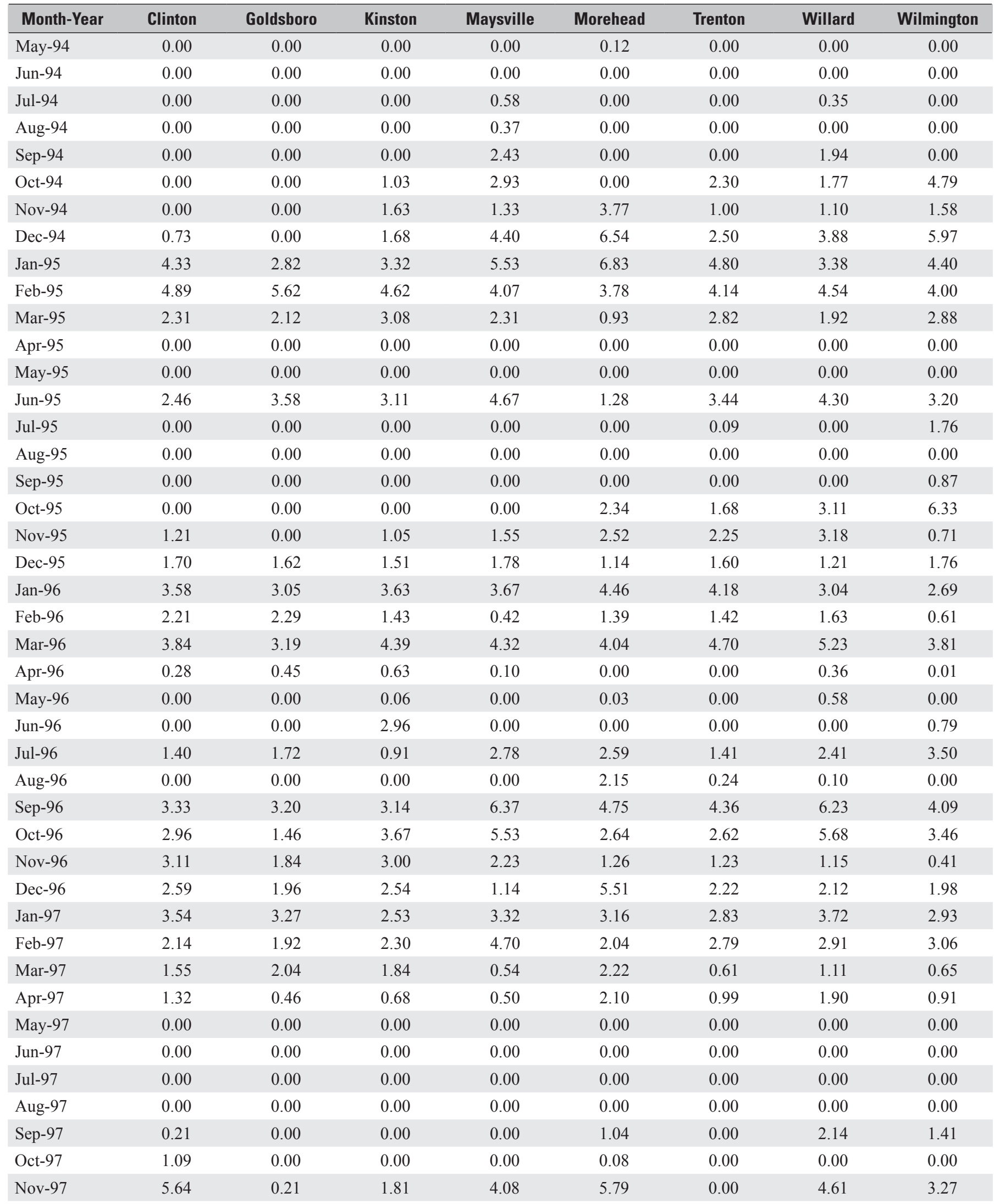


Table 2. Monthly estimated net groundwater recharge at climate sites in the vicinity of Onslow County, North Carolina.-Continued [All units are in inches]

\begin{tabular}{|c|c|c|c|c|c|c|c|c|}
\hline Month-Year & Clinton & Goldsboro & Kinston & Maysville & Morehead & Trenton & Willard & Wilmington \\
\hline Dec-97 & 4.27 & 4.25 & 4.90 & 3.73 & 5.00 & 3.04 & 4.05 & 4.30 \\
\hline Jan-98 & 6.81 & 7.26 & 5.28 & 4.95 & 6.79 & 5.19 & 5.50 & 6.58 \\
\hline Mar-98 & 5.40 & 5.92 & 2.68 & 1.22 & 1.44 & 2.20 & 1.74 & 0.69 \\
\hline Apr-98 & 2.36 & 5.14 & 1.74 & 1.37 & 2.25 & 2.01 & 3.61 & 0.18 \\
\hline Jun-98 & 0.00 & 0.00 & 0.00 & 0.00 & 0.00 & 0.00 & 0.00 & 0.00 \\
\hline Jul-98 & 0.00 & 0.00 & 0.00 & 0.00 & 0.00 & 0.00 & 0.00 & 0.00 \\
\hline Aug-98 & 0.00 & 0.00 & 0.44 & 3.40 & 0.00 & 0.00 & 0.00 & 1.88 \\
\hline Sep-98 & 0.00 & 0.00 & 0.00 & 1.91 & 0.00 & 0.00 & 0.00 & 0.45 \\
\hline Oct-98 & 0.00 & 0.00 & 0.00 & 0.00 & 0.00 & 0.00 & 0.00 & 0.00 \\
\hline Feb-99 & 0.93 & 0.98 & 1.13 & 0.99 & 1.68 & 1.07 & 1.57 & 1.20 \\
\hline Mar-99 & 1.45 & 0.40 & 2.70 & 1.93 & 1.81 & 2.27 & 2.72 & 2.02 \\
\hline Apr-99 & 1.29 & 0.12 & 0.00 & 1.04 & 0.65 & 0.48 & 0.11 & 2.01 \\
\hline May-99 & 0.00 & 0.00 & 0.00 & 0.00 & 0.00 & 0.00 & 0.00 & 3.84 \\
\hline Jun-99 & 0.00 & 0.00 & 0.00 & 0.00 & 0.00 & 0.00 & 0.00 & 0.00 \\
\hline Jul-99 & 0.00 & 0.00 & 0.00 & 0.00 & 0.00 & 0.00 & 0.00 & 0.00 \\
\hline Aug-99 & 0.00 & 0.00 & 0.00 & 0.00 & 1.54 & 0.00 & 0.00 & 0.00 \\
\hline Sep-99 & 6.91 & 11.50 & 8.18 & 6.04 & 3.51 & 8.11 & 7.33 & 8.66 \\
\hline Apr-00 & 2.09 & 2.47 & 1.97 & 4.94 & 5.16 & 3.24 & 2.03 & 2.32 \\
\hline May-00 & 0.00 & 0.00 & 0.00 & 0.00 & 0.00 & 0.00 & 0.00 & 0.00 \\
\hline Jun-00 & 0.41 & 0.00 & 0.00 & 0.00 & 2.44 & 0.00 & 0.25 & 0.00 \\
\hline Jul-00 & 0.00 & 0.00 & 0.00 & 1.62 & 4.19 & 2.13 & 3.85 & 0.97 \\
\hline Aug-00 & 0.00 & 0.00 & 0.00 & 1.84 & 3.85 & 0.58 & 0.04 & 2.59 \\
\hline Sep-00 & 0.00 & 0.53 & 1.66 & 3.23 & 6.21 & 3.37 & 2.09 & 3.53 \\
\hline Oct-00 & 0.00 & 0.00 & 0.00 & 0.00 & 0.00 & 0.00 & 0.00 & 0.00 \\
\hline Nov-00 & 0.00 & 0.29 & 0.43 & 2.88 & 3.27 & 0.69 & 0.54 & 2.15 \\
\hline Dec-00 & 1.18 & 3.00 & 1.83 & 3.77 & 2.96 & 1.87 & 1.85 & 1.43 \\
\hline Jan-01 & 0.37 & 0.74 & 0.82 & 1.57 & 1.01 & 1.66 & 0.33 & 0.24 \\
\hline Feb-01 & 2.50 & 1.94 & 2.22 & 2.00 & 1.66 & 1.89 & 2.52 & 1.44 \\
\hline Mar-01 & 3.95 & 5.36 & 3.23 & 4.32 & 2.84 & 3.78 & 6.34 & 7.09 \\
\hline Apr-01 & 0.00 & 0.00 & 0.00 & 0.00 & 0.00 & 0.00 & 0.99 & 0.00 \\
\hline May-01 & 0.00 & 0.00 & 0.00 & 0.14 & 0.00 & 0.00 & 0.68 & 0.00 \\
\hline Jun-01 & 0.00 & 0.00 & 0.93 & 1.69 & 0.00 & 1.21 & 0.29 & 0.00 \\
\hline
\end{tabular}


Table 2. Monthly estimated net groundwater recharge at climate sites in the vicinity of Onslow County, North Carolina.-Continued [All units are in inches]

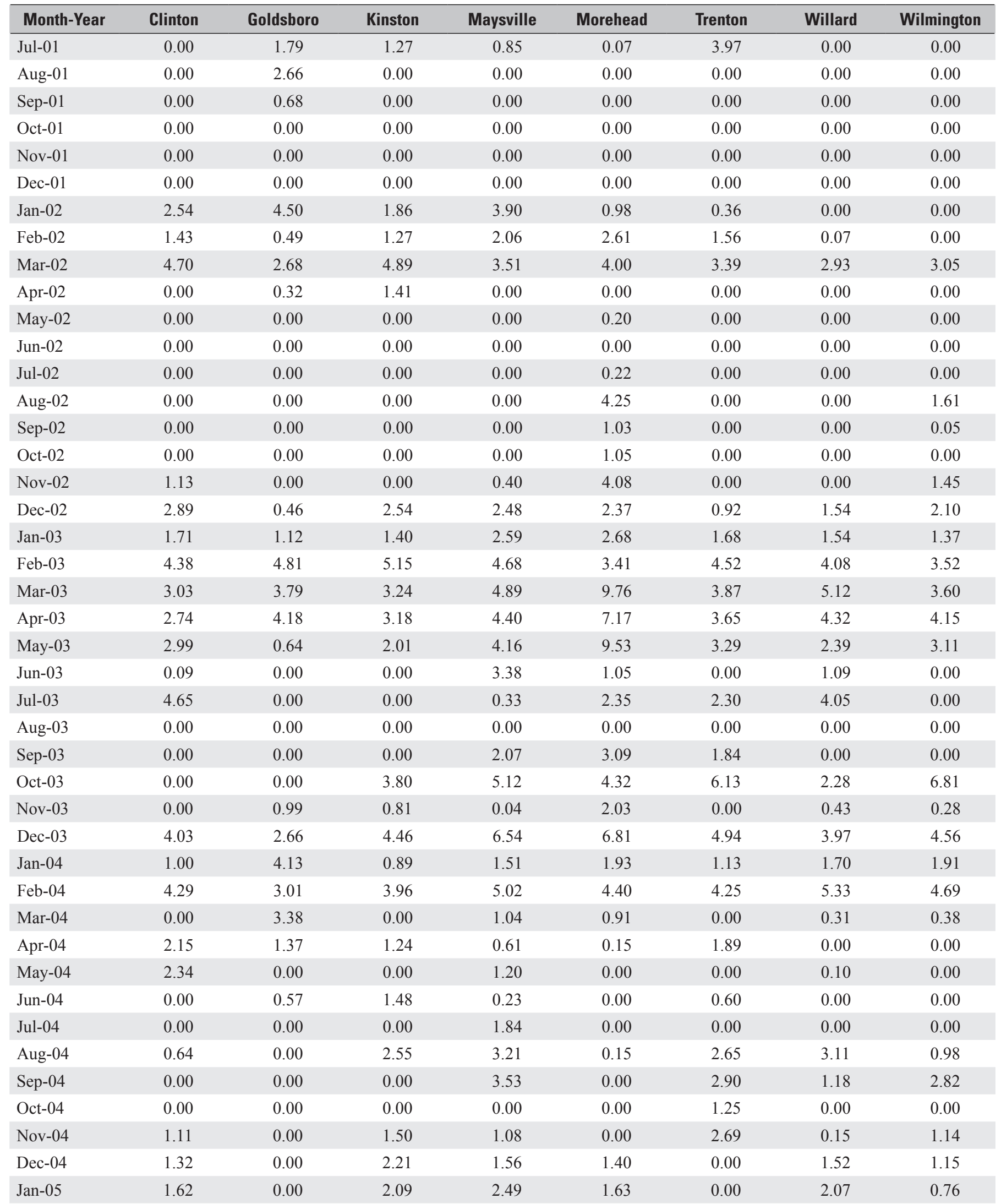


Table 2. Monthly estimated net groundwater recharge at climate sites in the vicinity of Onslow County, North Carolina.-Continued [All units are in inches]

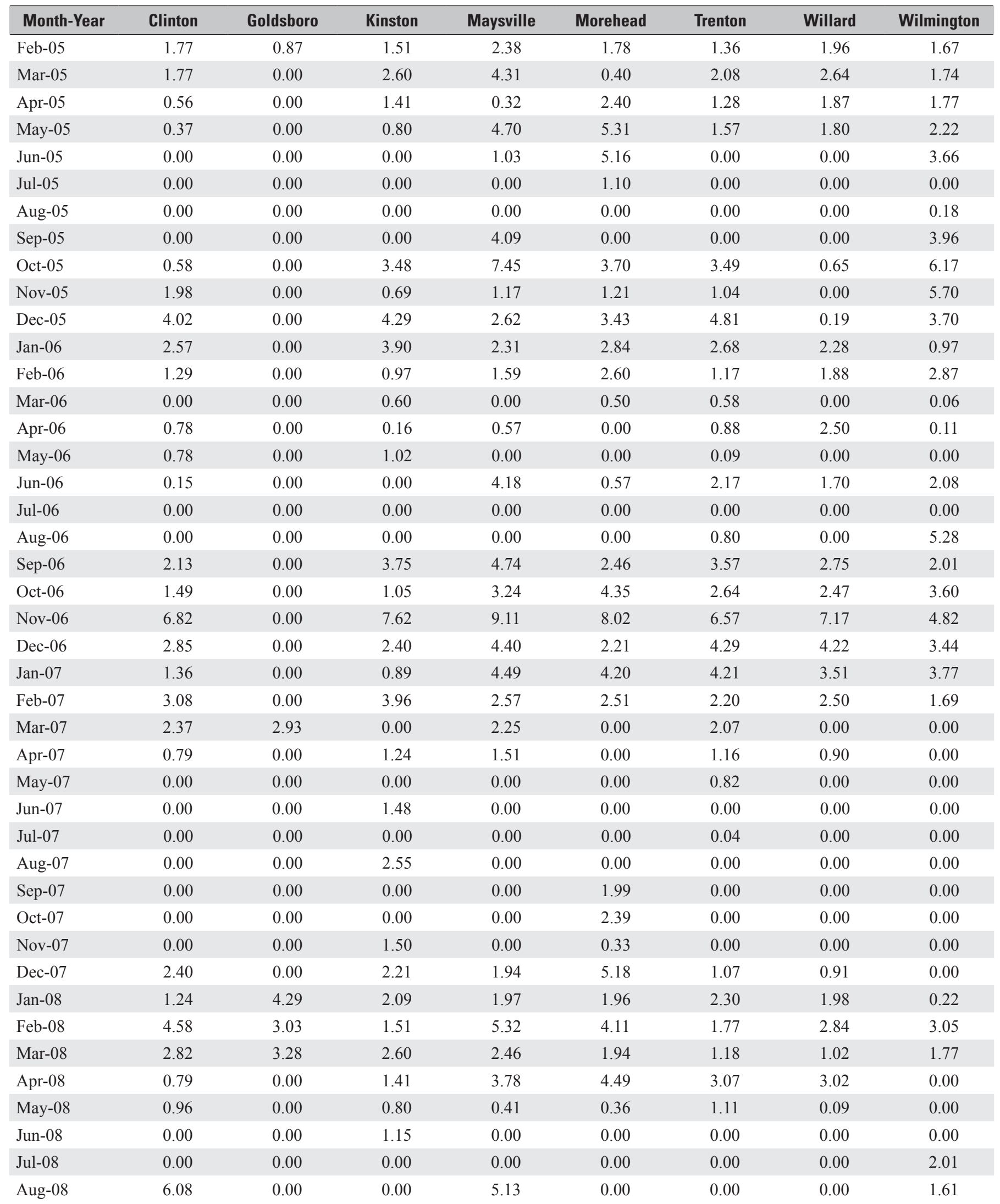


Table 2. Monthly estimated net groundwater recharge at climate sites in the vicinity of Onslow County, North Carolina.—Continued [All units are in inches]

\begin{tabular}{|c|c|c|c|c|c|c|c|c|}
\hline Month-Year & Clinton & Goldsboro & Kinston & Maysville & Morehead & Trenton & Willard & Wilmington \\
\hline Sep-08 & 5.73 & 1.37 & 0.00 & 0.00 & 0.00 & 0.37 & 1.28 & 5.38 \\
\hline Oct-08 & 0.00 & 0.09 & 0.00 & 0.55 & 0.00 & 0.00 & 0.06 & 0.85 \\
\hline Nov-08 & 4.47 & 3.63 & 3.48 & 2.50 & 6.72 & 1.20 & 3.27 & 3.70 \\
\hline Dec-08 & 0.50 & 2.32 & 0.69 & 2.73 & 2.80 & 2.63 & 2.29 & 2.09 \\
\hline Jan-09 & 1.35 & 2.75 & 4.29 & 1.82 & 1.61 & 1.97 & 1.32 & 1.60 \\
\hline Feb-09 & 0.67 & 0.69 & 3.90 & 1.71 & 1.33 & 1.17 & 1.48 & 1.09 \\
\hline Mar-09 & 4.35 & 5.67 & 0.97 & 2.02 & 1.28 & 3.10 & 2.04 & 2.36 \\
\hline Apr-09 & 0.00 & 0.85 & 0.60 & 0.33 & 0.22 & 0.71 & 1.87 & 0.00 \\
\hline May-09 & 0.15 & 0.11 & 0.16 & 0.73 & 0.88 & 0.44 & 3.43 & 2.22 \\
\hline Jun-09 & 0.00 & 0.00 & 1.02 & 0.00 & 0.00 & 0.00 & 0.00 & 0.00 \\
\hline Jul-09 & 0.00 & 0.00 & 0.00 & 0.00 & 0.00 & 0.00 & 0.00 & 1.66 \\
\hline Aug-09 & 3.43 & 0.00 & 0.00 & 2.12 & 0.00 & 2.11 & 2.01 & 0.70 \\
\hline Sep-09 & 0.00 & 0.00 & 0.00 & 2.29 & 0.00 & 0.00 & 0.00 & 5.48 \\
\hline Oct-09 & 0.00 & 0.00 & 7.50 & 0.00 & 0.00 & 0.00 & 0.00 & 0.00 \\
\hline Nov-09 & 1.48 & 2.10 & 1.05 & 8.49 & 5.82 & 5.75 & 3.21 & 3.15 \\
\hline Dec-09 & 5.44 & 5.59 & 7.62 & 5.91 & 7.39 & 7.85 & 6.79 & 8.32 \\
\hline Jan-10 & 4.16 & 4.08 & 3.32 & 3.31 & 6.02 & 4.93 & 3.70 & 3.20 \\
\hline Feb-10 & 4.06 & 4.50 & 4.89 & 4.10 & 3.27 & 3.61 & 3.74 & 4.00 \\
\hline Mar-10 & 3.66 & 3.36 & 2.16 & 1.44 & 5.23 & 1.75 & 1.94 & 2.47 \\
\hline Apr-10 & 0.00 & 0.00 & 0.00 & 0.00 & 0.00 & 0.00 & 0.00 & 0.00 \\
\hline May-10 & 0.11 & 0.00 & 0.00 & 0.00 & 0.00 & 0.00 & 0.00 & 0.00 \\
\hline Jun-10 & 0.00 & 0.00 & 0.00 & 0.00 & 0.00 & 0.00 & 0.82 & 0.00 \\
\hline Jul-10 & 0.00 & 0.00 & 0.00 & 0.00 & 0.00 & 0.00 & 0.00 & 0.00 \\
\hline Aug-10 & 0.00 & 0.00 & 0.00 & 0.45 & 0.00 & 0.00 & 0.00 & 0.00 \\
\hline Sep-10 & 1.32 & 0.10 & 2.02 & 8.00 & 2.01 & 5.57 & 2.96 & 7.40 \\
\hline Oct-10 & 0.00 & 1.58 & 2.33 & 0.00 & 0.00 & 5.28 & 0.00 & 0.00 \\
\hline Nov-10 & 0.00 & 0.00 & 0.26 & 0.00 & 0.00 & 0.00 & 0.76 & 0.00 \\
\hline Dec-10 & 0.87 & 2.99 & 2.35 & 3.18 & 2.96 & 3.07 & 1.27 & 2.42 \\
\hline
\end{tabular}




\section{Saltwater Contamination}

The distribution of saltwater and location of the freshwater/saltwater interface vary within each aquifer owing to the complexity of the depositional history that resulted in multiple discontinuous aquifer and confining unit layers within the Coastal Plain (Campbell and Coes, 2010). The Cretaceous aquifers in the southeastern part of the study area are saline and transition to freshwater to the northeast. A number of wells tapping the Castle Hayne aquifer in the study area have become more saline over time even though the freshwater/ saltwater interface is farther offshore. The increase in salinity suggests upconing from deeper saline aquifers or the existence of a conduit or paleochannel that breaches a confining unit, resulting in brackish surface-water entering the shallow aquifers. Cardinell and others $(1990,1993)$ found evidence of these paleochannels in the Castle Hayne aquifer beneath the New River by using seismic reconnaissance. These paleochannels are a physical mechanism that could facilitate saltwater migration in wells that are far away from the freshwater/ saltwater interface. Other studies at the Cherry Point Marine Corps Air Station near Havelock, North Carolina, and the area near Hilton Head, South Carolina (located in a similar depositional environments), have identified paleochannels as a source for downward migration of saltwater (Cardinell, 1999; Daniel and others, 1996; Foyle and others, 2001; Falls and others, 2005; Provost and others, 2006; Payne, 2010).

For this study, existing interpretations of the freshwater/ saltwater interface and the limited measurements of chloride were the main sources of data used to determine the salinity of groundwater in the study area. Additionally, recent measurements of specific conductance in wells were converted to chloride concentrations, using an equation described by Hem (1985).

\section{Groundwater Flow and Solute Transport Model Development}

Prior to development of the variable-density model of the aquifer system in the study area, a freshwater (constant density) groundwater-flow model was developed and calibrated for the freshwater part of the system, using the MODFLOW-2000 code (Harbaugh and others, 2000). The properties from the groundwater single-density model were extended into the saline aquifer areas, and the variabledensity code SEAWAT-2000 (Langevin and others, 2007) was applied for simulation of the freshwater and seawater system (Langevin and others, 2007).

\section{Layering}

Only the top six aquifers of the eight present in the study area (figs. 3 and 9) were used in the model developed for this study (figs. 9 and 10):

- model layer 1, the surficial aquifer

- model layer 2, the surficial and upper Castle Hayne confining unit (The updip and western part of the layer is simulated as the Peedee and Black Creek confining units. Updip, near the Fall Line, the layer is simulated as the surficial aquifer.)

- model layer 3, the upper Castle Hayne aquifer (The Castle Hayne aquifers and the lower Castle Hayne confining unit pinch out in Brunswick, Pender, Duplin, Lenoir, and Pitt Counties and are, therefore, simulated as a confining unit north and west of this area. Updip, near the Fall Line, the layer is simulated as the surficial aquifer.)

- model layer 4, the lower Castle Hayne confining unit (see detailed description for layer 3)

- model layer 5, the lower Castle Hayne aquifer (see detailed description for layer 3)

- model layer 6, the Beaufort confining unit (The Beaufort aquifer and confining unit pinch out in Onslow, Jones, Lenoir, and Pitt Counties and are, therefore, simulated as a confining unit north and west of this area. Updip, near the Fall Line, the layer is simulated as the surficial aquifer.)

- model layer 7, the Beaufort aquifer (see detailed description for layer 6)

- model layer 8, the Peedee confining unit (The Peedee aquifer and confining unit pinch out in Pitt, Greene, Jones, Lenoir, Duplin, Sampson, and Bladen Counties and are therefore, simulated as a confining unit north and west of this area. Updip, near the Fall Line, the layer is simulated as the surficial aquifer.)

- model layer 9, the Peedee aquifer (see detailed description for layer 8)

- model layer 10, the Black Creek confining unit (Updip, near the Fall Line, the layer is simulated as the surficial aquifer.)

- model layer 11, the Black Creek aquifer (Updip, near the Fall Line, the layer is simulated as the surficial aquifer.) 
The tops and extents of these aquifers and confining units, except the surficial aquifer, were determined by using geophysical logs, drillers' logs and other available data from 123 wells and boreholes (Fine, 2008). An estimate of the top of the surficial aquifer was created for each grid cell by using the mean elevation from the 30-meter National Elevation Dataset (NED; U.S. Geological Survey, 2013b). The coastal extent of the model was based on the previously determined freshwater/saltwater interface used by Campbell and Coes (2010). The updip extent is based on the actual extent of the coastal sediments as previously mapped by Gellici and Lautier (2010). The northeast and southwest extents were not based on hydrogeologic boundaries of the aquifer and confining units, but rather, placed along groundwater flow paths at estimated divides from potentiometric maps produced by Campbell and Coes (2010). Constant heads for each stress period were estimated from Campbell and Coes (2010) at the model cells along these northeast and southwest boundary sides, and testing of the effect of these two lateral boundaries at the study area is described later in this report. An extensive confining unit is beneath the Black Creek aquifer, and there is no groundwater development in deeper Upper and Lower Cape Fear aquifers (fig. 3 ) in the study area because of the presence of saltwater. Campbell and Coes, (2010) indicated minimal leakage between the Black Creek and deeper aquifers. Thus, the deeper units below the Black Creek aquifer were not incorporated into this model, and no testing of this boundary condition was conducted as part of this study.

The MODFLOW-2000 code (Harbaugh and others, 2000) requires that each model layer be continuous throughout the entire model area. In general, model layers represented an aquifer or confining unit; however, a minimum thickness was required even when a hydrogeologic unit pinched out. For that reason, and to control drying or flooding in layer 1, each model layer was given a minimum thickness - $30 \mathrm{ft}$ for layer 1 and $5 \mathrm{ft}$ for all other layers. In areas where the aquifers or confining units pinched out, the hydraulic properties of the underlying layers were assigned to the missing hydrogeologic unit in that layer. A general schematic (figs. 9 and 10) illustrates how the model layers and these "pinchouts" were discretized and incorporated into zones that reflect hydrogeologic unit properties.

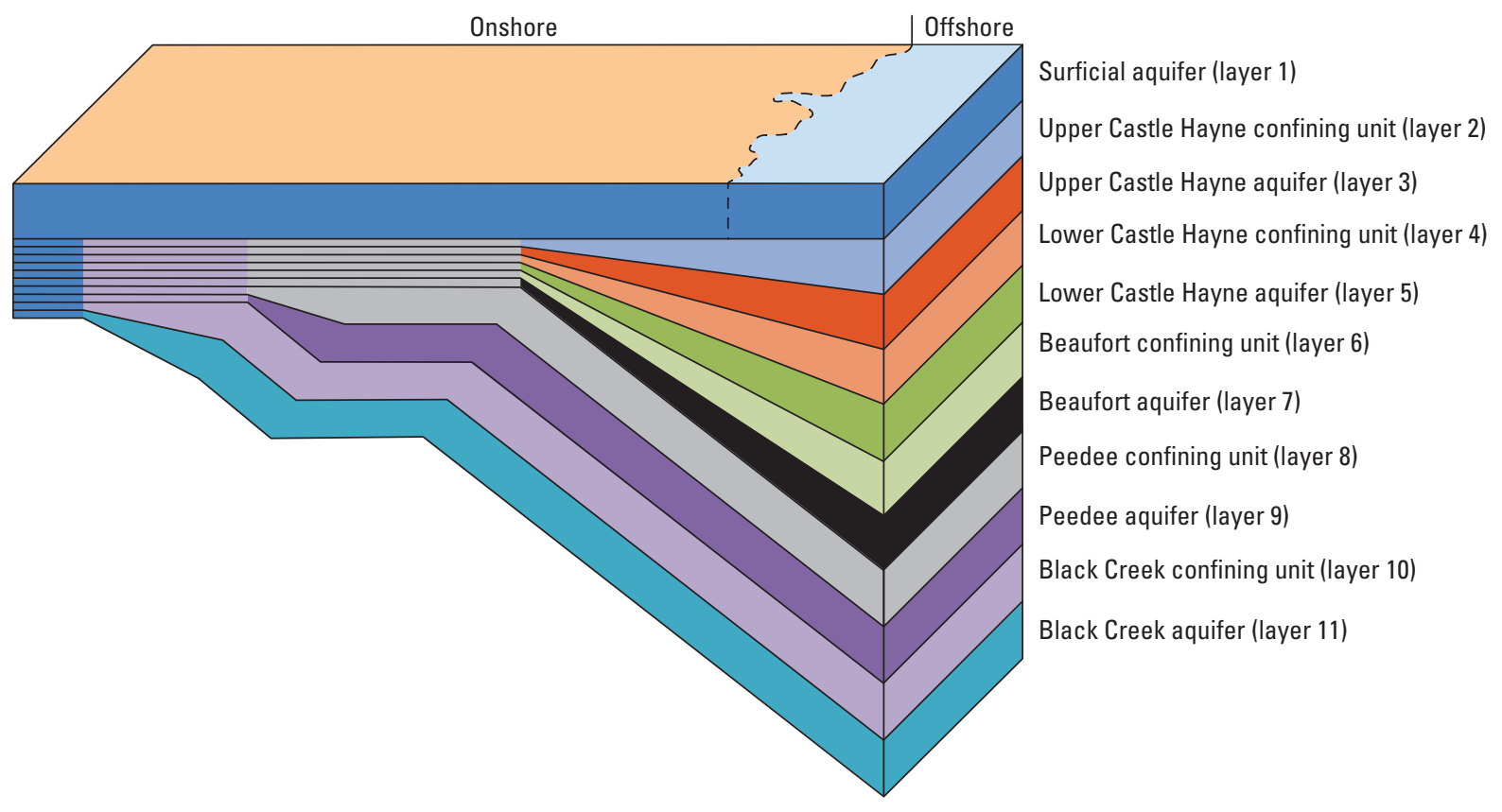

Figure 9. Generalized dip cross section showing how aquifers and confining units correspond with model layers. 


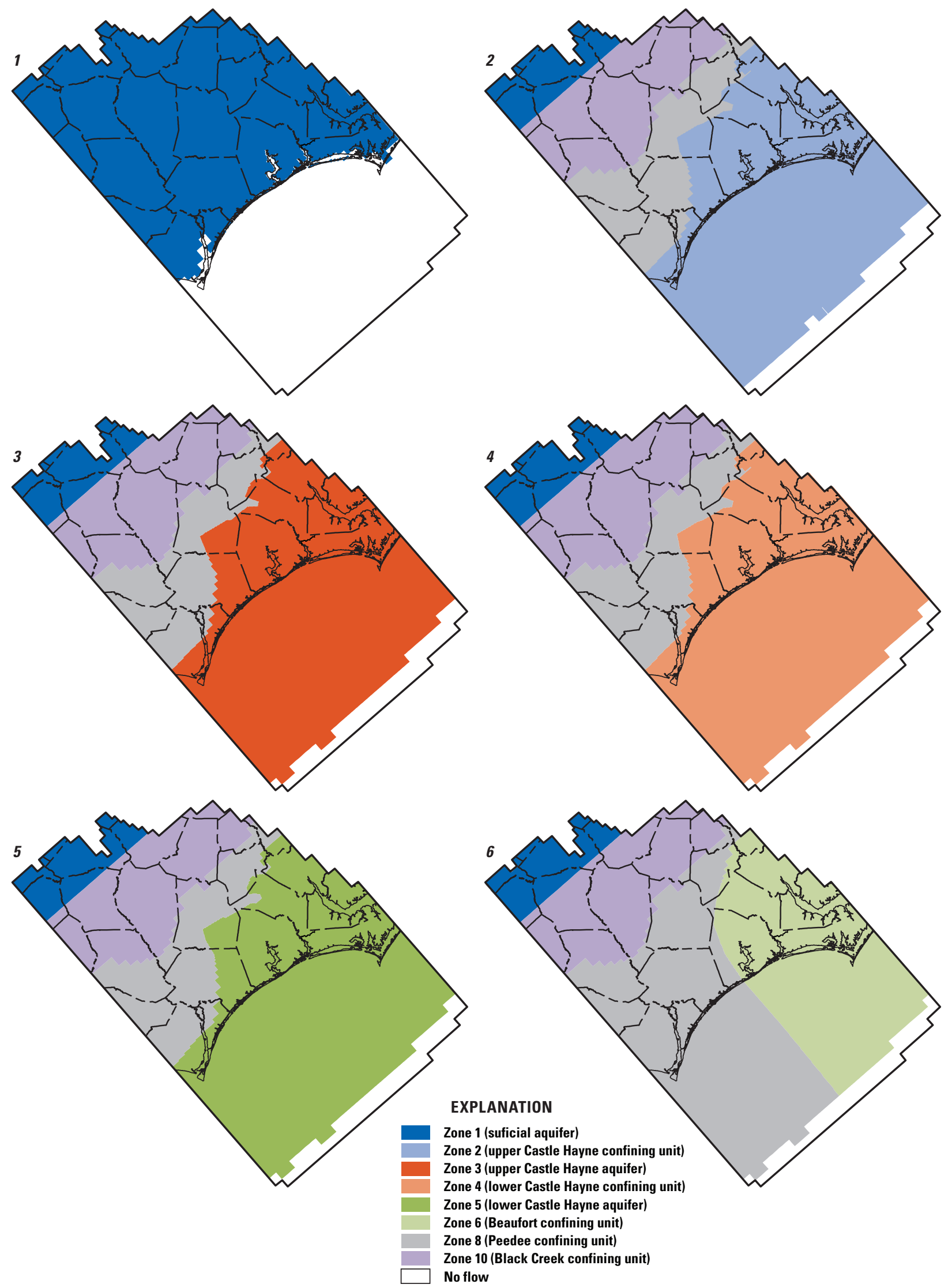

Figure 10. Maps showing zones used in model calibration for (1) model layer 1, (2) model layer 2, (3) model layer 3, (4) model layer 4, (5) model layer 5, (6) model layer 6, (7) model layer 7, (8) model layer 8, (9) model layer 9, (10) model layer 10, and (11) model layer 11. 

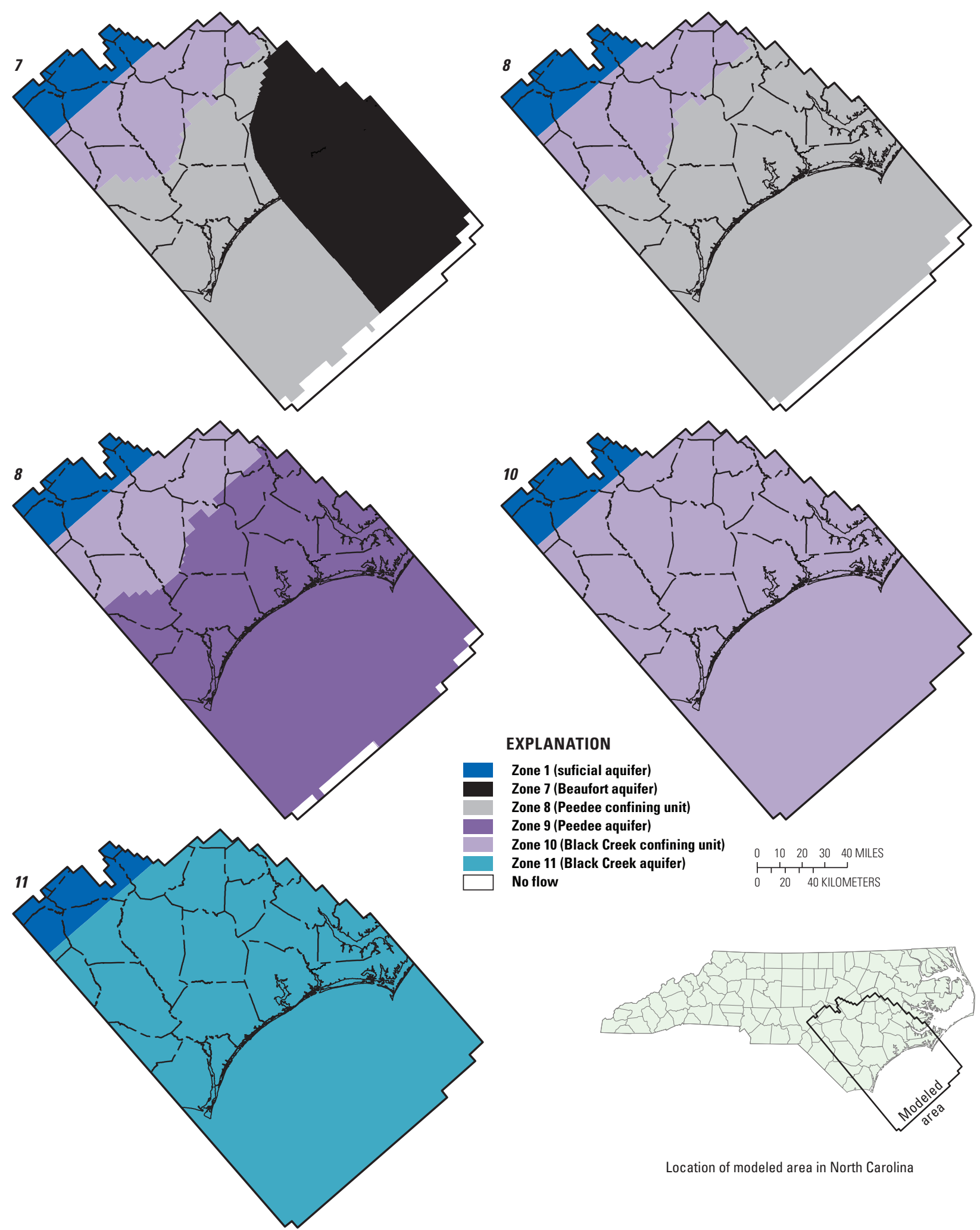

EXPLANATION

Zone 1 (suficial aquifer)

Zone 7 (Beaufort aquifer) Zone 8 (Peedee confining unit)

Zone 9 (Peedee aquifer)

Zone 10 (Black Creek confining unit)

Zone 11 (Black Creek aquifer)

No flow
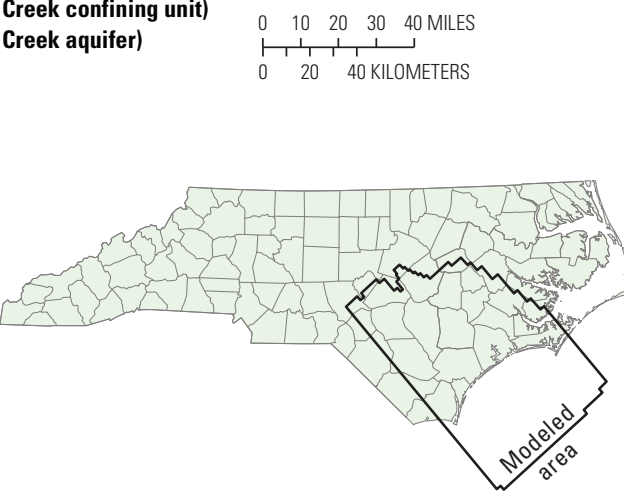

Location of modeled area in North Carolina

Figure 10. Maps showing zones used in model calibration for (1) model layer 1, (2) model layer 2, (3) model layer 3, (4) model layer 4, (5) model layer 5, (6) model layer 6, (7) model layer 7, (8) model layer 8, (9) model layer 9, (10) model layer 10, and (11) model layer 11. - Continued 


\section{Spatial Discretization}

The model grid encompasses $23,039 \mathrm{mi}^{2}$, of which approximately 84 percent is actively simulated. The irregular grid (fig. 11) is constructed of 280 rows and 188 columns, with a maximum cell size of $2 \mathrm{mi}^{2}$ on the edges of the model and a minimum cell size of $0.25 \mathrm{mi}^{2}$ focused over the study area. The grid is oriented 41 degrees west of north on its longest axis. The variably spaced grid allows for better resolution in the study area, while allowing the full model area to extend to hydrogeologic boundaries or groundwater divides far away from the area of interest. Thus, the effect of error in the location or specified head at the boundary on simulated water levels in the study area can be minimized, while having relatively fast model simulation times to facilitate calibration.

\section{Temporal Discretization}

The model simulates flow from predevelopment (1900-1909) to 2010 using 72 stress periods (table 3 ). The first stress period represents the steady-state conditions of predevelopment. The next seven stress periods are 10 years in length and represent conditions from 1910 to 1979. The following 20 stress periods are 1 year in length and represent 1980 to 1999 . The last 44 stress periods represent quarterly stress periods from 2000 to 2010, which allow the seasonal variations that exist in the data to be simulated.

\section{Boundary Conditions}

Groundwater-flow models, such as MODFLOW, can have three types of boundary conditions: specified head, specified flow, and head-dependent flow. Different packages within MODFLOW are used to implement the various boundary conditions (Harbaugh and others, 2000; Reilly, 2001). Flux boundary conditions applied in this model are the net groundwater recharge and groundwater pumpage, applied using the Recharge and Well packages of MODFLOW-2000, respectively. Specified heads (constant heads) were applied as an elevation of zero (approximately mean sea level) along the coast outside of the study area, and head-dependent flux boundary condition was applied using the General Head package for part of the coast in the study area (finer grid, fig. 11). Perennial streams and swamps were simulated using the Drain package in the top layer of the model.

No-flow boundaries were used to represent the termini of the model on the northeast, southwest, and northwest edges of the model. No-flow boundaries were also used to simulate areas in the model where seawater was in direct contact with the underlying confining unit.

\section{Flux Boundaries}

Net groundwater recharge was applied to the top layer of the model except at constant head cells on the basis of the estimates over time for each climate station (table 2). Thiessen polygons were developed to create zones of equal net groundwater recharge application at each stress period (fig. 12).
Model cells are much greater in area than areas of streams within a cell, thus the net groundwater recharge was applied to cells with drains or general head boundaries in the top layer.

Groundwater pumpage was applied at a model cell and layer depending on the location and construction of the well for the commercial, industrial, mining, and public-supply (CIMP) wells. The majority of the CIMP wells are in the upper and lower Castle Hayne and Black Creek aquifers, model layers 3, 5 and 11, respectively. Many wells in the model area withdraw water from multiple aquifers and were simulated as such. Figure $13 \mathrm{~A}$ shows the location of CIMP wells and the top model layer to which the pumpage is assigned. In the northwestern part of the study area many towns rely on surface water for their water supply.

Records on pumpage were not available for individual wells on Camp Lejeune from their inception to 2008. However, pumping data from the five water-treatment plants, the locations of the wells that provided water to each of the water-treatments plants, and the corresponding well yields for each well were used to calculate an estimate of the water pumped from each well (shown in figure $13 \mathrm{~A}$ as part of the CIMP wells). The estimation method is described in Faye and Valenzuela (2007).

The State of North Carolina does not require that agricultural, livestock, or domestic withdrawals be reported. However, water-use data are estimated by the USGS every 5 years as part of the USGS National Water-Use Information Program (U.S. Geological Survey, 2013b) and past national water-use summaries. Beginning in 1985, the county totals for each category also included the amount of water that is supplied from surface water and the amount supplied from groundwater sources. All three categories of groundwater withdrawal have increased since 1985, but were not as great prior to 1985 . Thus, pre-1985 agricultural, livestock, or domestic withdrawals were not included in the simulation. The 5-year county total for each county was interpolated through time for estimation of the withdrawals for the intervening years.

Agricultural, livestock, and domestic withdrawal locations are also not reported. However, locations of livestock farms are available from the North Carolina Division of Water Quality, and a land-use spatial dataset was available to determine irrigated areas in each county (Fry and others, 2011). Thus, the livestock withdrawal total per county was divided by the total number of farm locations in a county and then placed in each farm location and assigned to the top most productive aquifer below the surficial aquifer (fig. 13B). The land-use polygons were used to create a ratio of agricultural acreage per model cell per county divided by total county acreage to apportion the county estimate to each model cell and assigned to the top most productive aquifer below the surficial aquifer. Almost every model cell had some agricultural acreage, thus the domestic total for each county was divided among all cells with agricultural acreage in each county. Two assumptions can be made for the livestock and agricultural water-use estimates: (1) livestock farms and agricultural acreage were the same from 1985 to 2010, and (2) livestock, agricultural, and domestic wells were drilled to the shallowest productive aquifer below the surficial aquifer. 
Table 3. Calendar period associated with each model stress period.

[Q, Quarter]

\begin{tabular}{|c|c|c|}
\hline Stress period & Length (in years) & $\begin{array}{l}\text { Time period } \\
\text { represented }\end{array}$ \\
\hline 1 & 10 & 1900-1909 \\
\hline 2 & 10 & 1910-1919 \\
\hline 3 & 10 & 1920-1929 \\
\hline 4 & 10 & 1930-1939 \\
\hline 5 & 10 & 1940-1949 \\
\hline 6 & 10 & 1950-1959 \\
\hline 7 & 10 & 1960-1969 \\
\hline 8 & 10 & 1970-1979 \\
\hline 9 & 1 & 1980 \\
\hline 10 & 1 & 1981 \\
\hline 11 & 1 & 1982 \\
\hline 12 & 1 & 1983 \\
\hline 13 & 1 & 1984 \\
\hline 14 & 1 & 1985 \\
\hline 15 & 1 & 1986 \\
\hline 16 & 1 & 1987 \\
\hline 17 & 1 & 1988 \\
\hline 18 & 1 & 1989 \\
\hline 19 & 1 & 1990 \\
\hline 20 & 1 & 1991 \\
\hline 21 & 1 & 1992 \\
\hline 22 & 1 & 1993 \\
\hline 23 & 1 & 1994 \\
\hline 24 & 1 & 1995 \\
\hline 25 & 1 & 1996 \\
\hline 26 & 1 & 1997 \\
\hline 27 & 1 & 1998 \\
\hline 28 & 1 & 1999 \\
\hline 29 & 0.25 & 2000 Q1 \\
\hline 30 & 0.25 & 2000 Q2 \\
\hline 31 & 0.25 & 2000 Q3 \\
\hline 32 & 0.25 & 2000 Q4 \\
\hline 33 & 0.25 & 2001 Q1 \\
\hline 34 & 0.25 & $2001 \mathrm{Q} 2$ \\
\hline 35 & 0.25 & $2001 \mathrm{Q} 3$ \\
\hline 36 & 0.25 & $2001 \mathrm{Q} 4$ \\
\hline
\end{tabular}

Table 3. Calendar period associated with each model stress period.-Continued

[Q, Quarter]

\begin{tabular}{|c|c|c|}
\hline Stress period & Length (in years) & $\begin{array}{l}\text { Time period } \\
\text { represented }\end{array}$ \\
\hline 37 & 0.25 & 2002 Q1 \\
\hline 38 & 0.25 & 2002 Q2 \\
\hline 39 & 0.25 & $2002 \mathrm{Q} 3$ \\
\hline 40 & 0.25 & $2002 \mathrm{Q} 4$ \\
\hline 41 & 0.25 & 2003 Q1 \\
\hline 42 & 0.25 & 2003 Q2 \\
\hline 43 & 0.25 & 2003 Q3 \\
\hline 44 & 0.25 & 2003 Q4 \\
\hline 45 & 0.25 & 2004 Q1 \\
\hline 46 & 0.25 & $2004 \mathrm{Q} 2$ \\
\hline 47 & 0.25 & 2004 Q3 \\
\hline 48 & 0.25 & $2004 \mathrm{Q} 4$ \\
\hline 49 & 0.25 & 2005 Q1 \\
\hline 50 & 0.25 & 2005 Q2 \\
\hline 51 & 0.25 & $2005 \mathrm{Q} 3$ \\
\hline 52 & 0.25 & 2005 Q4 \\
\hline 53 & 0.25 & $2006 \mathrm{Q} 1$ \\
\hline 54 & 0.25 & 2006 Q2 \\
\hline 55 & 0.25 & 2006 Q3 \\
\hline 56 & 0.25 & 2006 Q4 \\
\hline 57 & 0.25 & 2007 Q1 \\
\hline 58 & 0.25 & 2007 Q2 \\
\hline 59 & 0.25 & 2007 Q3 \\
\hline 60 & 0.25 & 2007 Q4 \\
\hline 61 & 0.25 & 2008 Q1 \\
\hline 62 & 0.25 & 2008 Q2 \\
\hline 63 & 0.25 & 2008 Q3 \\
\hline 64 & 0.25 & 2008 Q4 \\
\hline 65 & 0.25 & 2009 Q1 \\
\hline 66 & 0.25 & 2009 Q2 \\
\hline 67 & 0.25 & 2009 Q3 \\
\hline 68 & 0.25 & 2009 Q4 \\
\hline 69 & 0.25 & 2010 Q1 \\
\hline 70 & 0.25 & 2010 Q2 \\
\hline 71 & 0.25 & $2010 \mathrm{Q} 3$ \\
\hline 72 & 0.25 & $2010 \mathrm{Q} 4$ \\
\hline
\end{tabular}




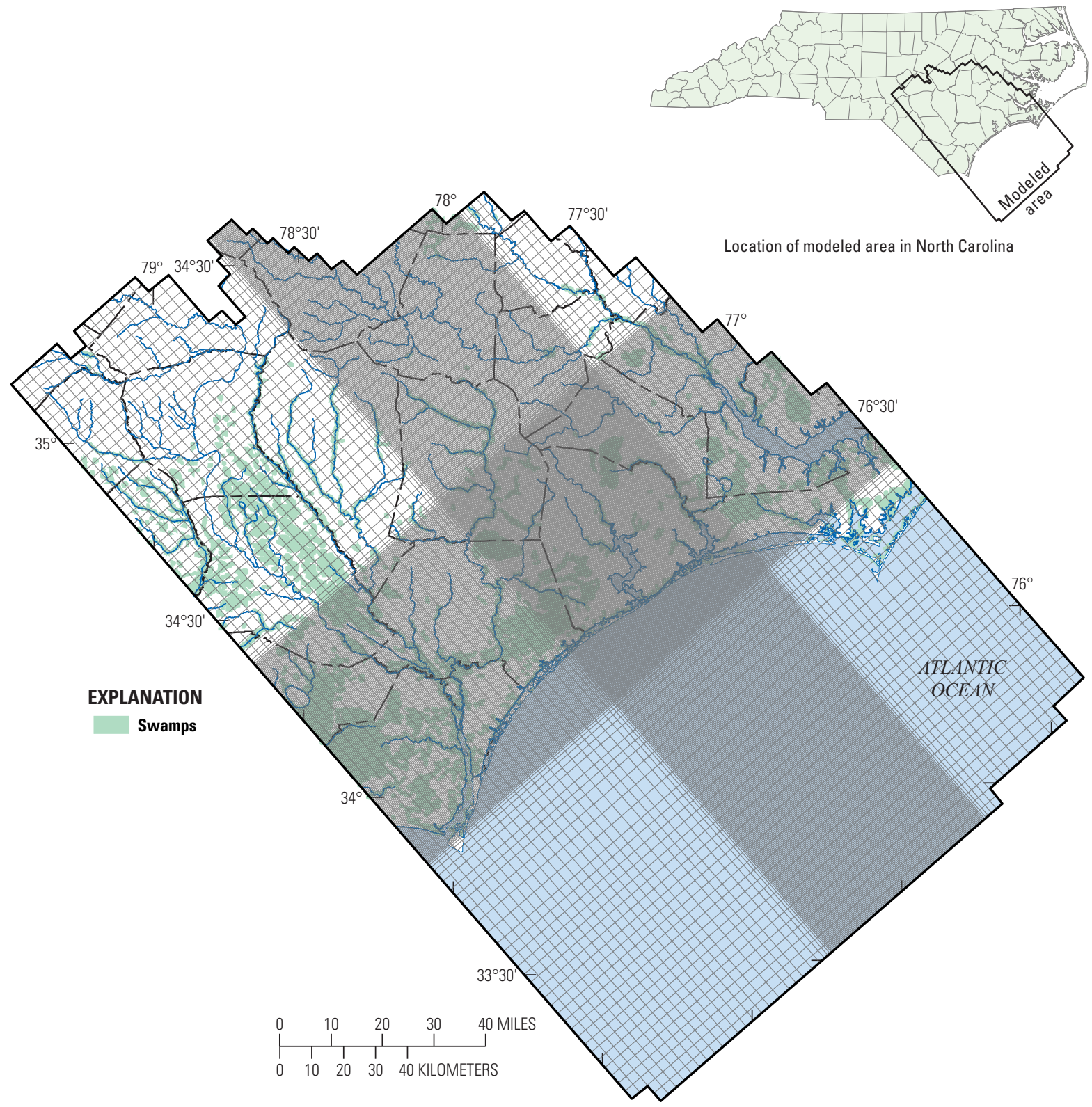

Figure 11. Map showing model grid and major surface-water features of the study area. 


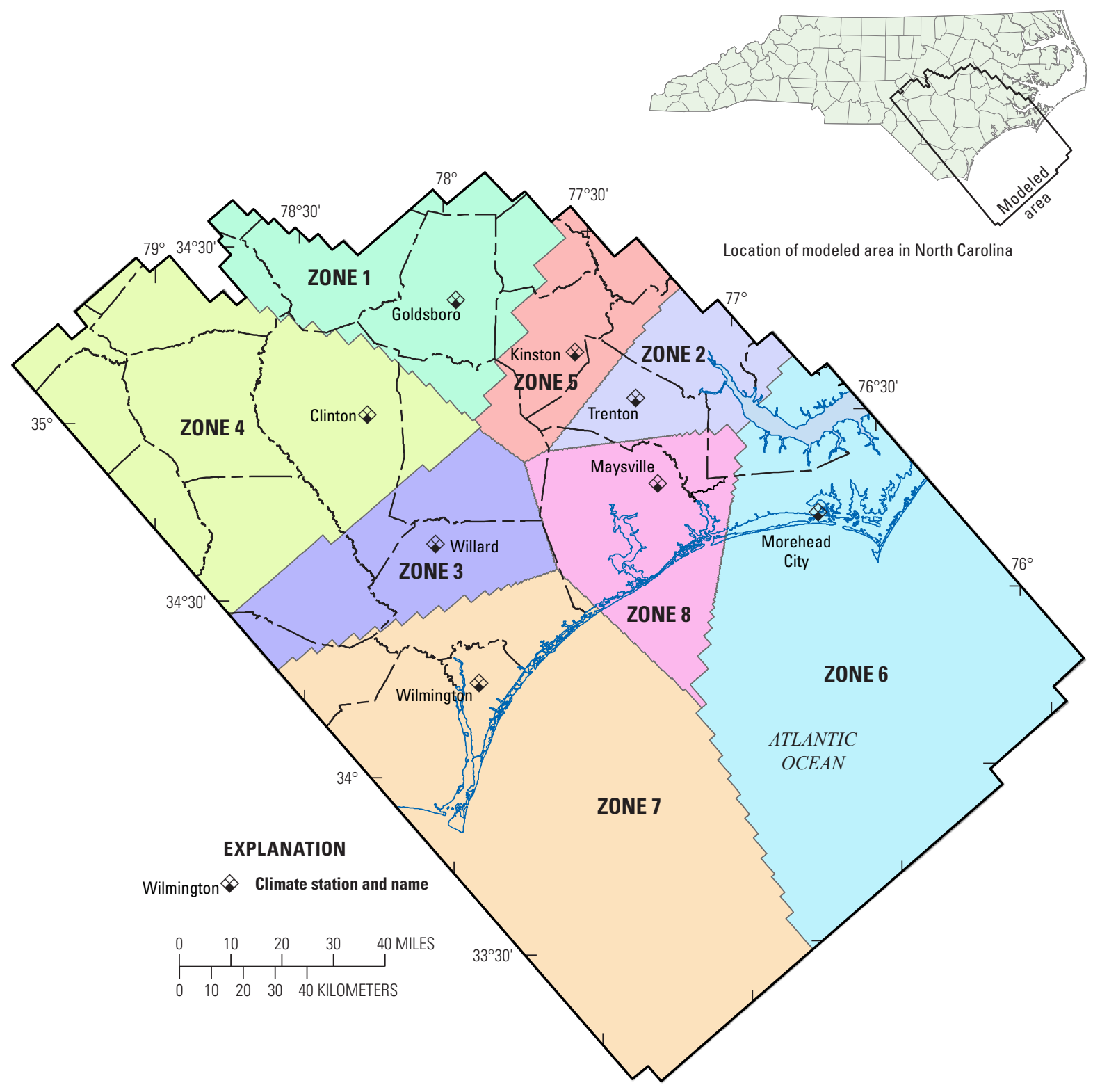

Figure 12. Map showing the cells of equal net groundwater recharge for each stress period used in the model. 


\section{$\boldsymbol{A}$}
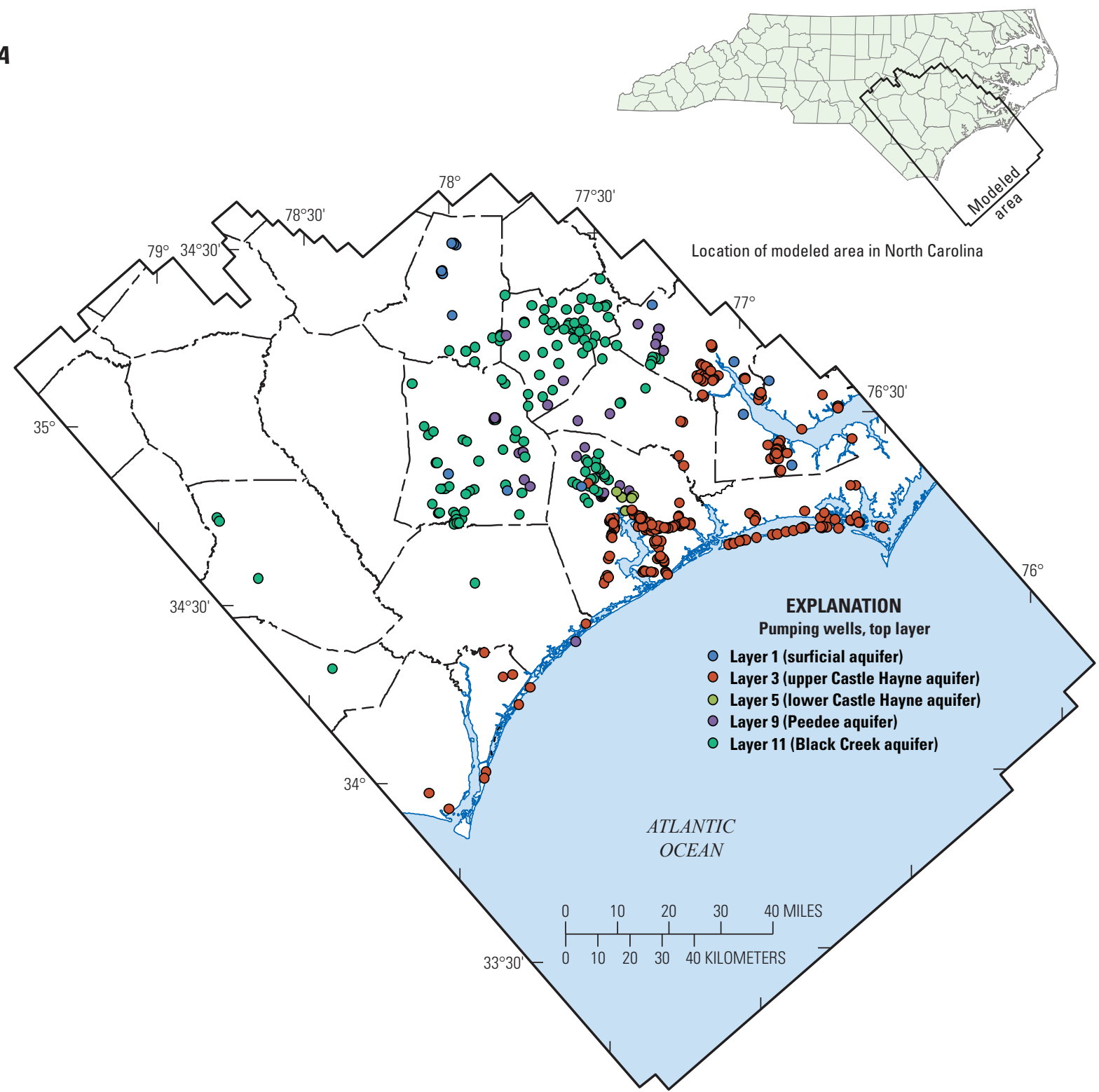

Figure 13. Map showing $(A)$ location of commercial, industrial, mining, and public-supply wells and model layer for each well, and $(B)$ location of livestock farm wells. 


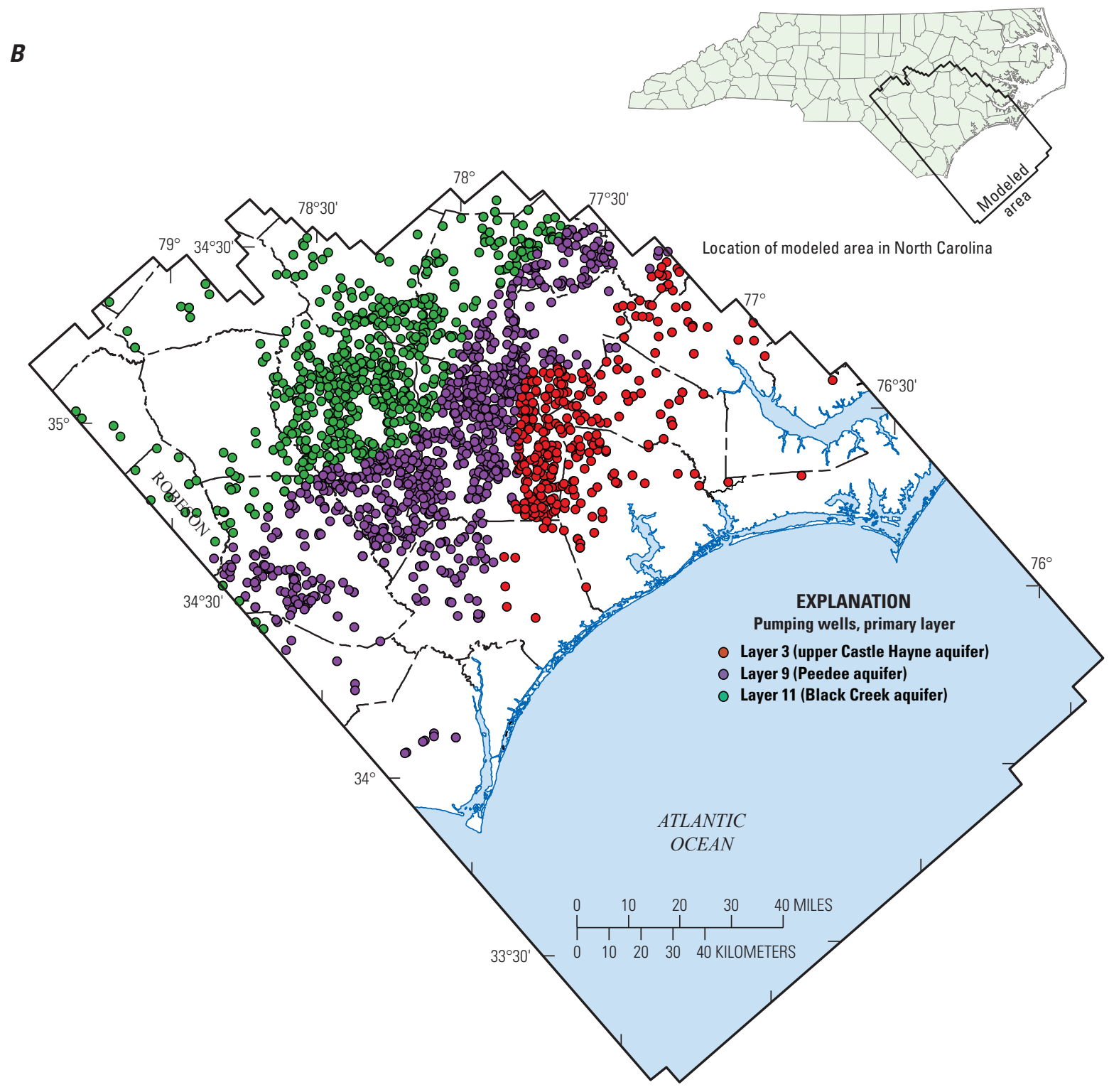

Figure 13. Map showing $(A)$ location of commercial, industrial, mining, and public-supply wells and model layer for each well, and $(B)$ location of livestock farm wells.-Continued 


\section{Head-Dependent Flux Boundaries}

Perennial streams and swamps were simulated using the Drain package available for MODFLOW-2000 (fig. 14). Although the entire cell is shaded for any cell with a drain, the simulated stream or swamp area does not cover the entire area of the cell for streams and simulated swampy areas may not be fully wet. The Drain package only allows water to flow out of the model based on simulated head. If the simulated head is greater than the drain head, the flow to the drain is based on the head difference (simulated head minus drain elevation) multiplied by the streambed hydraulic conductance. If the simulated head drops below the drain elevation, the flow is set to zero. The location of the cells with drains was determined from spatial datasets of perennial streams. The drain head was set to $5 \mathrm{ft}$ below the average land-surface elevation of the cell. Setting the drain head to the average land surface elevation minus $5 \mathrm{ft}$ rather than the minimum land surface may introduce some elevation error for the drain at the largest cells; however, this practice avoids problems with drain elevation getting set below the base of model layer 1 . In the more detailed grid area, the error introduced is much less as the variance in land surface is much less. Additionally, using the minimum land-surface value from the NED may also be inappropriate as the stream represented by the drain slopes along the stream and the drain feature must represent the average for the stream over the entire cell. The streambed hydraulic conductance was calculated from the length of the perennial stream as determined from the digital stream dataset, an assumed width of $1 \mathrm{ft}$, an assumed thickness of the riverbed sediments of $1 \mathrm{ft}$, and a vertical hydraulic conductivity of the sediment of 20 feet per day (ft/d). The vertical hydraulic conductivity value was calibrated by trial and error and is between the calibrated range of 1.9 to $80 \mathrm{ft} / \mathrm{d}$ that Campbell and Coes (2010) reported.

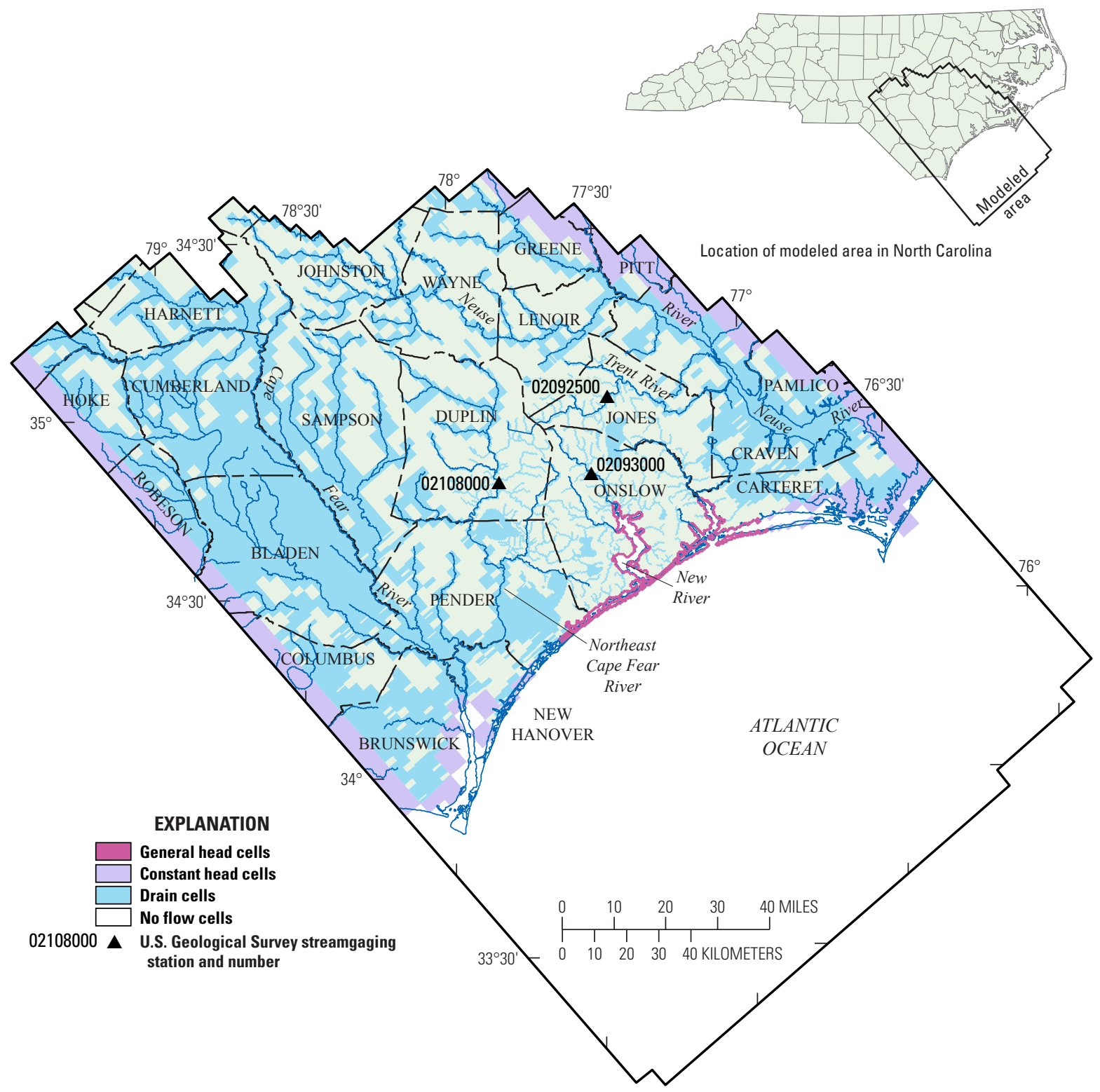

Figure 14. Map showing location of drains, constant head, and general head boundary conditions applied to the surficial aquifer, model layer 1. 
For features that create head-dependent fluxes over an area (cells adjacent to the coast and off shore where flow is assumed upward), the General Head boundary package was used (figs. 14 and 15). For the top two layers (the surficial aquifer and the upper Castle Hayne confining unit), in cells along the coast where freshwater discharge occurs, the constant head assigned was zero and the conductance was calculated on the basis of the cell area multiplied by the vertical hydraulic conductivity ( $15 \mathrm{ft} / \mathrm{d}$ for layer 1 and $0.0001 \mathrm{ft} / \mathrm{d}$ for layer 2) of the materials in the cell divided by an assumed thickness of $1 \mathrm{ft}$. The range in calculated conductance used for these cells is between $1.16 \times 10^{5}$ and $3.92 \times 10^{5} \mathrm{ft}^{2} / \mathrm{d}$ for layer 1 , the surficial aquifer, and between 174.2 and $882 \mathrm{ft}^{2} / \mathrm{d}$ for layer 2, the Castle Hayne confining unit (fig. 15).

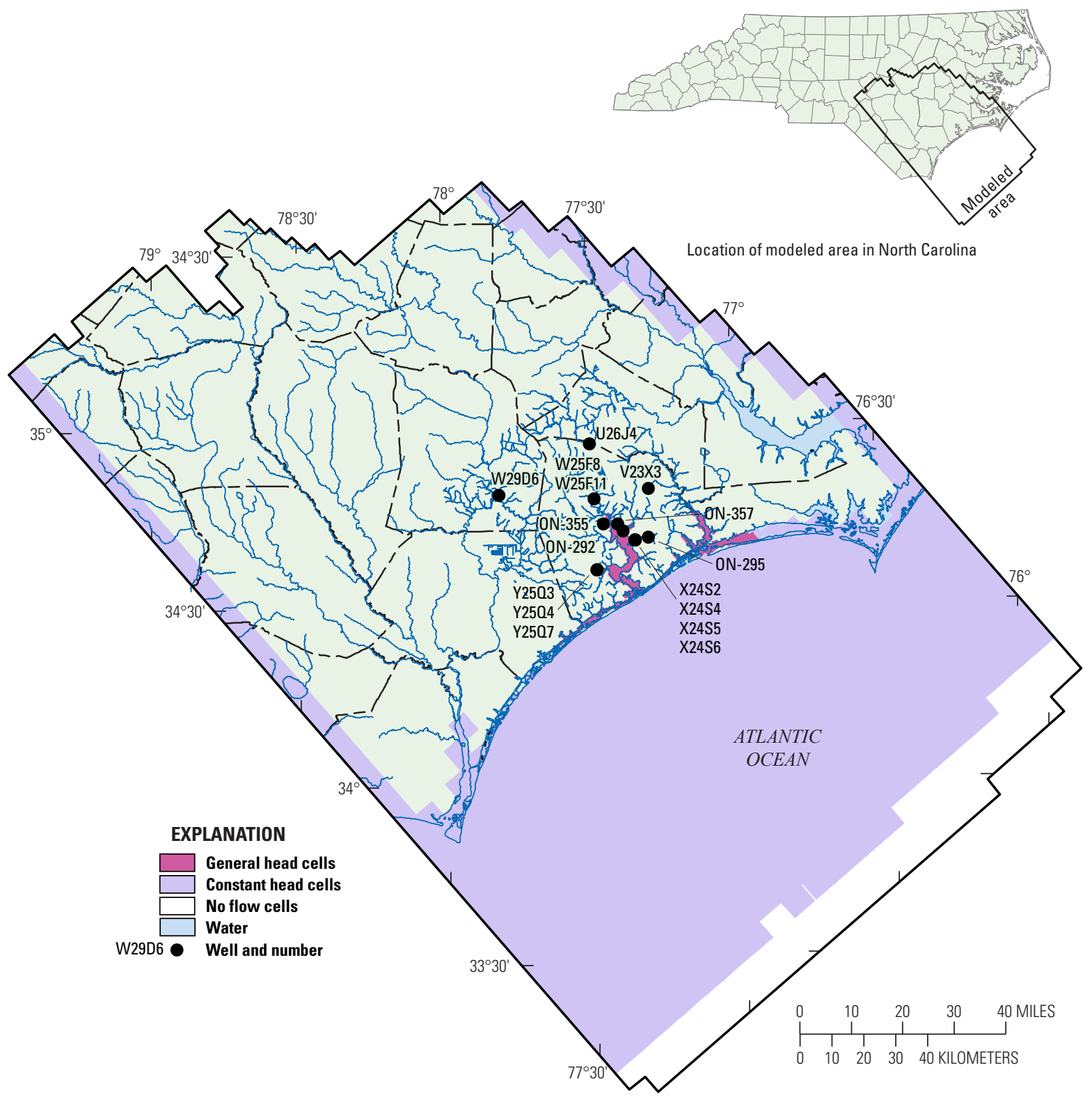

Figure 15. Map showing selected wells, simulated streams, and location of general head and constant head boundary conditions applied to the upper Castle Hayne confining unit, model layer 2. 


\section{Testing of Lateral Constant Head Boundary Conditions}

As stated previously, the northeastern and southwestern boundaries of the model area are within the extent of aquifers and confining units. A constant head was specified for each stress period and layer at these boundaries. The head values from predevelopment to 2004 were derived from the Campbell and Coes (2010) model, and the head values from 2005 to 2010 were derived from the North Carolina Division of Water Resources (2013c) potentiometric maps. Since no head data exists for the confining units, the head values for the underlying aquifers were assigned to these layers. Model cells at the coast were set with a head value of zero (approximately mean sea level). To test how errors in these lateral boundaries may affect the solution for hydraulic heads in Onslow County, inland lateral constant heads for each stress period were increased by $5 \mathrm{ft}$. The changes in head at the center of Onslow County caused by the adjusted lateral boundary conditions generally were less than $0.1 \mathrm{ft}$ for the top nine layers. Layers 10 and 11 had head values that were approximately $0.75 \mathrm{ft}$ greater in the center of Onslow County. This maximum difference is believed to be due to the large cone of depression located in layer 11 in Onslow County (shown later on simulated potentiometric surfaces) but is only 0.25 percent of the total drawdown over the calibration period. Thus, the simulated error associated with errors in the constant head lateral boundary is far less than the errors in the elevation of the water-level observations (described below in the Model Calibration section).

\section{Hydraulic Properties}

The aquifers underlying Onslow County, in descending order, are the surficial, upper and lower Castle Hayne, Beaufort, Peedee, Black Creek, and Upper and Lower Cape Fear aquifers. There are limited aquifer test data for the surficial aquifer; Campbell and Coes (2010) reported a simulated horizontal hydraulic conductivity of $216 \mathrm{ft} / \mathrm{d}$, and Smith and Chapman (2005) reported hydraulic conductivity values between 3 and $21 \mathrm{ft} / \mathrm{d}$ and specific yields between 0.08 and 0.1 from aquifer tests for the surficial aquifer. For unconsolidated sedimentary rocks similar to those found in the North Carolina Coastal Plain, Halford and Kuniansky (2002) report a likely range of 0.1 to $100 \mathrm{ft} / \mathrm{d}$ for horizontal hydraulic conductivity for the surficial aquifer in central Florida; 1 to $100 \mathrm{ft} / \mathrm{d}$ for terrace deposits in Texas; and 30 to $200 \mathrm{ft} / \mathrm{d}$ for the sediments of the Gulf Coastal Plain. The specific yield range from Smith and Chapman (2005) indicates unconfined conditions at the two sites. The reported range in horizontal hydraulic conductivity for the Atlantic Coastal Plain from northern Georgia to southern Virginia was compiled by Campbell and Coes (2010) as follows: the Yorktown aquifer is 4.0 to $1,340 \mathrm{ft} / \mathrm{d}$; the Castle Hayne aquifer is 1 to $170 \mathrm{ft} / \mathrm{d}$; the Beaufort aquifer is 2 to $1,300 \mathrm{ft} / \mathrm{d}$; the Peedee aquifer is 3 to $220 \mathrm{ft} / \mathrm{d}$; the Black Creek aquifer is 2 to $300 \mathrm{ft} / \mathrm{d}$; the Upper and Lower Cape Fear aquifers is 1 to $100 \mathrm{ft} / \mathrm{d}$. The hydraulic properties from aquifer tests used in this study are provided in table 4 and fit within the range of values reported in Campbell and Coes (2010).

Table 4. Compilation of hydraulic properties calculated from aquifer tests in the Coastal Plain of North Carolina.

[Kh, Horizontal hydraulic conductivity; ft/d, feet per day;-, no data; SS, specific storage; ft, feet; Sy, Specific Yield]

\begin{tabular}{|c|c|c|c|c|c|c|c|c|}
\hline Hyraulic property & $\begin{array}{l}\text { Surficial } \\
\text { aquifer }^{1}\end{array}$ & $\begin{array}{l}\text { Yorktown } \\
\text { aquifer }\end{array}$ & $\begin{array}{c}\text { Castle Hayne } \\
\text { aquifer }\end{array}$ & $\begin{array}{l}\text { Beaufort } \\
\text { aquifer }\end{array}$ & $\begin{array}{l}\text { Peedee } \\
\text { aquifer }\end{array}$ & $\begin{array}{c}\text { Black Creek } \\
\text { aquifer }\end{array}$ & $\begin{array}{l}\text { Upper Cape } \\
\text { Fear aquifer }\end{array}$ & $\begin{array}{l}\text { Lower Cape } \\
\text { Fear aquifer }\end{array}$ \\
\hline Number of Kh observations & 7 & 14 & 63 & 4 & 18 & 63 & 16 & 3 \\
\hline Minimum Kh $(\mathrm{ft} / \mathrm{d})$ & 3 & 0.4 & 1 & 10 & 1 & 1 & 2 & 1 \\
\hline Maximum Kh $(\mathrm{ft} / \mathrm{d})$ & 21 & 50 & 222 & 20 & 30 & 70 & 60 & 10 \\
\hline Median $\mathrm{Kh}(\mathrm{ft} / \mathrm{d})$ & 6 & 20 & 20 & 20 & 6 & 7 & 9 & 2 \\
\hline Kh standard deviation $(\mathrm{ft} / \mathrm{d})$ & 6 & 16 & 44 & 5 & 8 & 12 & 18 & 5 \\
\hline Number of SS observations & 7 & 5 & 4 & 1 & 9 & 6 & 1 & 0 \\
\hline Minimum SS $\left(\mathrm{ft}^{-1}\right)$ & $6.5 \times 10^{-4}$ & $1.9 \times 10^{-7}$ & $2.1 \times 10^{-8}$ & - & $7.4 \times 10^{-8}$ & $2.1 \times 10^{-7}$ & - & - \\
\hline Maximum SS $\left(\mathrm{ft}^{-1}\right)$ & $6.8 \times 10^{-3}$ & $3.2 \times 1^{-6}$ & $1.6 \times 10^{-6}$ & - & $2.1 \times 10^{-5}$ & $6.7 \times 10^{-6}$ & - & - \\
\hline Median SS $\left(\mathrm{ft}^{-1}\right)$ & $1.4 \times 10^{-3}$ & $1.4 \times 10^{-6}$ & $4.2 \times 10^{-8}$ & $2.7 \times 10^{-5}$ & $1.5 \times 10^{-6}$ & $1.5 \times 10^{-6}$ & $5.0 \times 10^{-7}$ & - \\
\hline $\begin{array}{l}\text { SS standard } \\
\text { deviation }\left(\mathrm{ft}^{-1}\right)\end{array}$ & $2.2 \times 10^{-3}$ & $1.1 \times 10^{-6}$ & $7.8 \times 10^{-7}$ & - & $6.5 \times 10^{-6}$ & $2.3 \times 10^{-6}$ & - & - \\
\hline $\begin{array}{l}\text { Number of Sy } \\
\text { observations }\end{array}$ & 7 & 0 & 0 & 0 & 0 & 0 & 0 & 0 \\
\hline Minimum Sy $\left(\mathrm{ft}^{-1}\right)$ & $9.0 \times 10^{-3}$ & - & - & - & - & - & - & - \\
\hline Maximum Sy $\left(\mathrm{ft}^{-1}\right)$ & $1.0 \times 10^{-1}$ & - & - & - & - & - & - & - \\
\hline Median Sy $\left(\mathrm{ft}^{-1}\right)$ & $3.0 \times 10^{-2}$ & - & - & - & - & - & - & - \\
\hline Sy standard deviation $\left(\mathrm{ft}^{-1}\right)$ & $3.5 \times 10^{-2}$ & - & - & - & - & - & - & - \\
\hline
\end{tabular}

${ }^{1}$ Data from Smith and Chapman (2005). 
There are limited hydraulic property data for the confining units and few estimates of specific storage for most of the confined aquifers and confining units in the Onslow County study area. The confining units in the study area are primarily composed of clay and silt. Generally, the confining units consist of a series of clay and silt beds of varying thickness and extent (fig. 3). The range in horizontal hydraulic conductivity for confining units, which was obtained through calibration of the southern Atlantic Coastal Plain regional model, was $9.9 \times 10^{-6}$ to $9.1 \times 10^{-2} \mathrm{ft} / \mathrm{d}$ (Campbell and Coes, 2010), with deeper units having smaller values. These values are within the range that is typical of silt and clay, $1 \times 10^{-5}$ to $1 \times 10^{-1} \mathrm{ft} / \mathrm{d}$ (Halford and Kuniansky, 2002). In general, sediments compact more with depth, thus both hydraulic conductivity and specific storage may decrease with depth for the deeper aquifers and confining units. Specific storage can be estimated from multiple observation well aquifer tests or from physical tests for determination of the bulk modulus of elasticity of materials. The values of specific storage from Campbell and Coes (2010) were determined by dividing the reported storage coefficient values by the thickness of the aquifer. Few field-determined values were available for the deeper aquifers and confining units in the study area. Specific storage values for the confined aquifers of the North Carolina Coastal Plain from multiple observation well aquifer tests range from $2.1 \times 10^{-5} \mathrm{ft}^{-1}$ to $7.4 \times 10^{-8} \mathrm{ft}^{-1}$ (table 4$)$.

\section{Model Calibration}

Once the conceptual model of the aquifer system is developed (delineation of aquifers and confining units; determination of where water recharges and discharges the system; estimates of the quantity of flows in and out of the system wherever possible; estimates of reasonable hydraulic properties; and compilation of observed or estimated water levels) and approximated in a mathematical context (grid resolution; model layering; and boundary conditions), the process of model calibration begins. Simply put, model calibration is the process of modification of hydraulic properties and stresses (model input datasets) in order to match observed water levels and flow estimates or measurements. Just as there are numerous ways to move from the conceptual model of the system to the mathematical approximation of the system, there are numerous methods and choices for model calibration. The calibration approach used in this study is described in this section of the report. The process is iterative. As calibration proceeds, often model construction problems are uncovered, and changes to the mathematical approximation of the system or calibration strategy are required. The details of the entire interim calibration steps are not described. The final calibration strategy and fit criteria are discussed.

No matter what method is used to calibrate a groundwaterflow model (trial and error or various parameter estimation codes), the final resulting model should have hydraulic properties within reasonable values and spatial distribution and should fit the observed water levels and flows within the error of these observations. Parameter estimation codes for MODFLOW are all variations of nonlinear regression to minimize the fit between the simulated and observed values (Doherty, 2001, 2003; Reilly and Harbaugh, 2004; Hill and Tiedeman, 2007). The groundwater flow equation results in non-unique solutions for hydraulic conductivity if only water levels are used for calibration (Emsellem and de Marsilly, 1971). The flux to and from a system everywhere is rarely known. For this reason, it is critical that all properties and fluxes are estimated and used to constrain the calibration along with the observed data for head and flow. Additionally, there may not be sufficient water-level and flow observations to help constrain the parameter estimation process adequately such that the final distribution of hydraulic conductivity and flux estimates match the hydrogeologic framework and flux measurements.

\section{Calibration Approach}

The parameter estimation code PEST (Doherty, 2001, 2003) was used to help calibrate the groundwater-flow model for this study. Zones and pilot points (point locations where the parameters are estimated) were used for hydraulic properties in each model layer. The use of pilot points allows a smoothly varying hydraulic conductivity from model cell to model cell that can honor the aquifer test data while minimizing large changes in hydraulic conductivity between cells that can lead to numerical problems in the groundwater-flow solution (Kuniansky and Danskin, 2003), and allows for regularization of the parameter estimation or inverse problem (Doherty and Hunt, 2010). The zones of hydraulic properties are defined on the basis of the actual extent of an aquifer or confining unit in each model layer (fig. 10), resulting in model layers having multiple zones as a result of aquifer and (or) confining units pinching out.

Pilot points for hydraulic properties were placed at aquifer test locations and in locations in an equally spaced grid where no aquifer test data have been collected. To achieve faster model runtimes during calibration, non-essential pilot points were removed in areas that were not important to the study (seaward locations in the lower layers for example). As a result of aquifers and confining units being represented by multiple (separate) model layers where units have pinched out (figs. 9 and 10), pilot points for hydraulic properties exist only in the model layer that represents the aquifer or confining unit and not in the pinched out layers (figs. 28-39). For hydraulic conductivity, the initial value of the pilot point at an aquifer test location was set to the calculated value from the aquifer test, and the maximum and minimum range was set to one order of magnitude higher and lower, respectively, than the aquifer test value. For pilot points with no aquifer test data (dummy pilot point), all of the initial values within a zone and maximum and minimum range were set to the median range for that corresponding aquifer or confining unit zone. The vertical anisotropy ratio for pilot points was placed at the hydraulic conductivity pilot point locations, given an initial 
value of 4 (unitless) and allowed to vary between 1 and 10 . For the calibration of specific storage, the median value of the aquifer was assigned to each zone for an initial value and was allowed to vary between 0.1 and $1.0 \times 10^{-08}$.

Net groundwater recharge also was set up in zones based on Thiessen polygons for each climate water-budget site (fig. 12; table 2). The initial estimated net groundwater recharge was used for each designated zone and stress period; however, during calibration, net groundwater recharge was allowed to be adjusted within the uncertainty of the estimate, using a multiplier that could vary for each stress period. The range in multiplier was 0.5 to 3 , owing to the fact that 20 percent of surplus is a fairly conservative starting value.

Groundwater withdrawal is considered a known flow; however, these data were not used as flow observations with associated uncertainty during calibration. Even though the majority of the withdrawals for individual wells is reported and not metered, no attempt to adjust withdrawals or estimate the accuracy of withdrawals was conducted as part of the study or incorporated into the calibration process by allowing withdrawals to vary during calibration.

Observed water levels were assigned to the well's corresponding aquifer as determined from construction data. While the depth to water is fairly accurately measured, the calculated land-surface elevation can be in error depending on how the elevation at each well is determined. For most of the wells, the land-surface elevation is estimated from topographic maps, and the accuracy is within half the contour interval of the topographic maps. Additionally, the exact geographic location of the well may be inaccurate depending on how the well was located. Thus the majority of the elevations of the water levels used in this study have an accuracy of plus or minus $5 \mathrm{ft}$ at best. Water-level observations in the surficial aquifer (model layer 1) were sparse, thus dummy water-level observation targets were placed in a grid pattern in layer 1 and calculated on the basis of the average land surface for the cell using the depth to water table regression equation from Kuniansky and others (2009). These dummy observation targets were set up using the PEST code (Doherty, 2005) as a maximum water level; in other words, simulated water levels should not be greater than the dummy observation. Additionally, a few drawdown targets were established within the measured cone of depression in Onslow County.

A reasonable fit to water-level elevation is achieved if the majority of weighted residuals (observed minus simulated heads) are less than two times the accuracy of the data to account for both general elevation accuracy and additional error in spatial location or variation during a stress period. Thus the calibration criteria for weighted head residuals are that the majority should be less than $10 \mathrm{ft}$ in the study area to consider the model well calibrated. Another measure of calibration fit is the standard deviation of weighted residuals divided by the range of the data (called normalized standard deviation). This dimensionless statistic is useful because it takes into account the range in water-level data used for calibration. Typically, as the range in observed water levels increases, the standard deviation of the associated calculated residuals also increases. Optimally, the standard deviation divided by the range will be less than 0.1 , meaning that the majority of the residuals are less than 10 percent of the range in observations (Kuniansky and others, 2004).

It is also desirable that the residuals be normally distributed and not have a spatial bias. A spatial bias occurs when all residuals are positive (simulated heads are lower than observed heads) in one area and negative (simulated heads are higher than observed heads) in another area. Normally distributed residuals with no spatial bias would be both positive and negative in a somewhat random pattern in all areas, resulting in the mean of the residuals equaling zero or close to zeroanother desirable characteristic of a good fit to the water-level data.

In the parameter estimation process, each observation in the model is given a weight. Weighting is used to better fit the regression to some observations more closely than other observations. Although weighting should be based on accuracy of observed data, it is often used subjectively to achieve a better fit in an area deemed more important for the model application (Hill and Tiedeman, 2007). Additionally, weighting must be used for creation of dimensionless derivatives of flow and head or drawdown observations. This particular model uses a variably spaced grid in order to have fine discretization in the area of interest (Onslow County) but cover an extent such that regional hydrogeologic boundaries are represented and uncertainties at the boundaries will have smaller effects on results in the local area of interest. This discretization scheme leads to less numerical accuracy (higher model error) and an expected poorer model fit in the coarse area of the model grid outside the area of interest. Thus, while water-level-elevation observations were used in the coarse area, they were generally given the weight of 0.1 , and observations inside the study area were generally given the weight of 0.95 for the 2004 and 2008 data sets and 1.5 for the continuous dataset. Also, because of assumed accuracy issues, predevelopment water-level-elevation observations inside the study area were given a weight of 0.5 .

Base flows were calculated at three USGS streamgages for the periods of record (fig. 14; table 5), for the periods of record (fig. 14; table 5) and were used for observations of groundwater discharge in the study area. The hydrograph separation computer program Web based Hydrograph Analysis Tool (WHAT; Lim and others, 2005) was used to separate the base-flow component from the overall streamflow using the recursive digital filtering method. The base-flow determination is done at the watershed scale and may include interflowwater in the unsaturated zone that moves toward the stream and does not enter the aquifer or in relatively flat terrain may even represent slow surface runoff drainage (Healy, 2010). There are numerous hydrograph separation methods, and comparisons of the various methods indicate that results are within about 25 percent of each other and, as stated previously, could differ from actual groundwater discharge by as much as 
a factor of two (Daniel and Harned, 1998; Kinzelbach and others, 2002; Stewart and others, 2007). The base-flow calculations were used as flux observations in the model; however, these observations were weighted very small in the model calibration so that the model did not try to match them exactly. Conductance parameters for the drains were not set up within the parameter estimation process to gain a better fit to the flux observations. In most of the study area, the deeper aquifers are not in direct connection with the streams and rivers. Some of the streamgages used for base-flow estimates are in relatively flat terrain with swampy areas; hydrograph separation tends to overestimate groundwater discharge in these conditions (Healy, 2010). Additionally, the model grid may not be fine enough to fully simulate all of the local groundwater discharge. Thus, base flow is considered an upper limit for simulated groundwater discharge to streams, meaning simulated values should be less than these base-flow observations.

\section{Calibration Results}

The model calibration fit was evaluated by comparing water-level measurements from individual stress periods for predevelopment, 2004, and 2008. Additionally, wells with time-series water-level measurements also were used in the calibration and are referred to as "continuous" water-level data throughout this report. The continuous measurement data were averaged throughout each stress period to give a single mean value for that stress period. Long-term base-flow calculations from three USGS streamgages were compared to average simulated base flow for the entire simulation period. The initial hydraulic conductivities were allowed to vary within a known range, and the final distributions are discussed in this section. Additionally, the initial estimates of net groundwater recharge for each stress period were allowed to vary, and the final values are discussed.

Table 5. Data for selected streamgages in the study area.

[USGS, U.S. Geological Survey; $\mathrm{mi}^{2}$, square miles; $\mathrm{ft}^{3} / \mathrm{s}$, cubic feet per second; $\mathrm{ft}^{3} / \mathrm{d}$, cubic feet per day; NC, North Carolina]

\begin{tabular}{|c|c|c|c|c|c|c|c|c|c|c|}
\hline $\begin{array}{l}\text { USGS } \\
\text { Station } \\
\text { Number }\end{array}$ & Station Name & $\begin{array}{c}\text { Station } \\
\text { Latitude } \\
\text { (decimal } \\
\text { degrees) }\end{array}$ & $\begin{array}{l}\text { Station } \\
\text { Longitude } \\
\text { (decimal } \\
\text { degrees) }\end{array}$ & $\begin{array}{l}\text { Drainage } \\
\text { area in } \\
\mathrm{mi}^{2}\end{array}$ & $\begin{array}{l}\text { Period of } \\
\text { record }\end{array}$ & $\begin{array}{c}\text { Mean } \\
\text { calculated } \\
\text { base flow, } \\
\text { in } \mathrm{ft}^{3} / \mathbf{s}^{1}\end{array}$ & $\begin{array}{c}\text { Mean } \\
\text { simulated } \\
\text { base } \\
\text { flow, in } \\
\mathrm{ft}^{3} / \mathrm{s}\end{array}$ & $\begin{array}{l}\text { Percentage of } \\
\text { simulated base } \\
\text { flows within } \\
\text { the } 50 \text {-percent } \\
\text { errror criteria }\end{array}$ & $\begin{array}{c}\text { Mean } \\
\text { calculated } \\
\text { base flow, } \\
\text { in } \mathrm{ft}^{3} / \mathbf{d}^{1}\end{array}$ & $\begin{array}{c}\text { Mean } \\
\text { simulated } \\
\text { base flow, } \\
\text { in } \mathrm{ft}^{3} / \mathrm{d}\end{array}$ \\
\hline 02108000 & $\begin{array}{l}\text { Northeast Cape } \\
\text { Fear River near } \\
\text { Chinquapin, NC }\end{array}$ & 34.829 & -77.832 & 599 & $\begin{array}{l}1940- \\
2008\end{array}$ & 432 & 56.9 & 10 & $3.73 \times 10$ & $4.91 \times 10$ \\
\hline 02092500 & $\begin{array}{c}\text { Trent River near } \\
\text { Trenton, NC }\end{array}$ & 35.064 & -77.461 & 168 & $\begin{array}{l}1951- \\
2008\end{array}$ & 102 & 119 & 55 & $8.78 \times 10$ & $1.04 \times 10$ \\
\hline 02093000 & $\begin{array}{l}\text { New River near } \\
\text { Gum Branch, } \\
\text { NC }\end{array}$ & 34.849 & -77.519 & 94 & $\begin{array}{c}1949- \\
2008\end{array}$ & 66.9 & 38.3 & 47 & $5.78 \times 10$ & $3.31 \times 10$ \\
\hline
\end{tabular}

${ }^{1}$ Mean calculated base flows were derived from the Recursive Digital Filter method (Lim and others, 2005). 
Simulation of Groundwater Flow and Saltwater Movement in the Onslow County Area, North Carolina

\section{Model Fit—Groundwater Levels}

Groundwater conditions for the predevelopment period were simulated using a steady-state stress period for the initial 10-year period (1900-1909 stress period 1, table 3). Water-level measurements from 140 wells (Campbell and Coes, 2010) in several aquifers (model layers 3 - upper Castle Hayne aquifer, 5 - lower Castle Hayne aquifer, 9 - Peedee aquifer, and 11 - Black Creek aquifer) were used for the steady-state predevelopment model calibration. Water-level measurements used for the predevelopment dataset were collected between 1900 and 1980. Because of the lack of predevelopment measurements in previous studies, groundwaterlevel measurements collected before 1980 were considered predevelopment for this study. Furthermore, owing to a lack of construction information for the wells, many water levels for the Castle Hayne aquifer were assigned to both the upper and lower Castle Hayne aquifers. The weighted residuals ranged from 6.22 to $-11.93 \mathrm{ft}$, with a mean of $-1.25 \mathrm{ft}$ and a root mean square error of $3.26 \mathrm{ft}$ (table 6; fig. 16). The residuals were close to normally distributed, with 99 percent of the values falling within the 10-ft calibration target range (histogram in figure 16). Although groundwater use was not reported prior to 1930 (fig. 5), some withdrawals from the Black Creek aquifer or shallower aquifers may have occurred in 1900-1909 and are not simulated, making observed water levels lower than simulated. The mean residual not equaling zero may, therefore, be the result of the observed water levels not being representative of predevelopment conditions. For the predevelopment water levels, the normalized standard deviation is 0.01 , indicating that the majority of the residuals are less than 1 percent of the range of the data.

Water-level conditions during the fourth quarter of 2004 were simulated during stress period 48 of the transient simulation (table 3). Sixty-seven groundwater-level measurements were made as part of a synoptic water-level data-collection effort in the fall of 2004 and compared to simulated heads at the end of stress period 48. A majority of the water-level measurements in the model area were made at sites that also had continuous groundwater-level data during the same period. The weighted residuals ranged from -11.8 to $32.2 \mathrm{ft}$ with a mean of $-0.06 \mathrm{ft}$ and a root mean square error of $4.67 \mathrm{ft}$ (table 7; fig. 17). The percentage of simulated values within the 10 -ft calibration target was 97 percent. The standard deviation divided by the range in 2004 water levels is 0.01 , indicating that the majority of the residual is less than 1 percent of the range in the data. Model layers 9 (Peedee aquifer) and 11 (Black Creek aquifer) have the poorest fit but meet all error criteria (table 7). On the basis of the 2004 model results, water-level observations had a maximum water-level decline of $175 \mathrm{ft}$ in the Black Creek aquifer since the predevelopment period (compare lowest observed water levels in figure 16 to figure 17). The mean weighted residual is slightly negative, but almost zero, owing to the simulation of water-level decline being slightly less than the observed decline in the Black Creek and Peedee aquifers. Additionally, almost all residuals are between -5 and $5 \mathrm{ft}$, which makes it difficult to determine if they are normally distributed on the histogram (fig. 17).

Groundwater conditions during the fourth quarter of 2008 were simulated during stress period 64 of the transient model (table 3). One hundred thirty-three groundwater-level measurements were collected as part of a synoptic datacollection effort in and around the study area in the fall of 2008. The calibration produced close to normally distributed weighted residuals ranging from -39.3 to $42.6 \mathrm{ft}$ with a mean of $1.26 \mathrm{ft}$ and a root mean square of $13.2 \mathrm{ft}$ (table 8; histogram in figure 18). The percentage of simulated values within the 10 -ft calibration target was 62 percent. The standard deviation of the residuals divided by the range in observed values for the 2008 water levels was 0.05 , indicating that the majority of residuals is less than 5 percent of the range in the observed data. Model layers 9 and 11 (Peedee and Black Creek aquifers, respectively) have the poorest fit with less than the majority of residuals meeting the 10 -ft error criteria (table 8). Additionally, the root mean square error is not approximately equal to the standard deviation for layers 9 and 11. The total number of values is small for calculation of statistics for layers 9 and 11 for this period. On the basis of the 2008 model results, waterlevel observations had a maximum water-level decline of $275 \mathrm{ft}$ since the predevelopment conditions in the Black Creek aquifer, and the mean simulated water level is lower than observed water levels. For the Peedee aquifer, however, the mean simulated water level is higher than the observed water level for five values.

Continuous groundwater-level measurements (4,392 measurements total) from 92 wells were used in calibration. These wells, with continuous or near-continuous data, have been part of groundwater data-collection networks in the model area during the study period. The weighted residuals range from -112 to $27.5 \mathrm{ft}$ with a mean of $-0.80 \mathrm{ft}$ and a root mean square error of $8.25 \mathrm{ft}$ (table 9; histogram in figure 19). The percentage of simulated values within the $10-\mathrm{ft}$ calibration target was 86 percent. The normalized standard deviation for the continuous record water levels was 0.02 , indicating that the majority of the weighted residuals are within less than 2 percent of the range of the observed data. The scatter plot (fig. 19) indicates that for most aquifers there is little bias; however, for model layers 9 and 11 (Peedee and Black Creek aquifers, respectively), there appear to be more negative residuals (simulated water levels are greater than observed water levels) than positive residuals, indicating some bias. For model layer 7 , the Beaufort aquifer, simulated values are less than observed values as indicated graphically and by the positive mean residual greater than 1 . For all layers, however, the majority of weighted water-level residuals are less than $10 \mathrm{ft}$.

As stated previously, groundwater withdrawals were not measured directly and the reported withdrawals were not adjusted during the calibration process. On the basis of the water-level observation data in Onslow County, the Black Creek aquifer has the greatest declines; thus, unreported groundwater withdrawal estimates would have the greatest impact on simulated water levels in the aquifers with the 
Table 6. Calibration statistics for simulated heads for predevelopment conditions.

\begin{tabular}{|c|c|c|c|c|c|c|}
\hline Calibration statistic & All_layers & Layer 3 & Layer 5 & Layer 7 & Layer 9 & Layer 11 \\
\hline $\begin{array}{l}\text { Number of } \\
\text { observations }\end{array}$ & 140 & 43 & 43 & 2 & 16 & 36 \\
\hline Range in observations (feet) & 337 & 36.8 & 36.8 & 32.0 & 74.0 & 327 \\
\hline Minimum weighted residual (feet) & -12.0 & -9.59 & -8.50 & -0.70 & -12.0 & -8.72 \\
\hline Maximum weighted residual (feet) & 6.21 & 4.67 & 4.27 & 6.21 & 5.98 & 3.17 \\
\hline Mean weighted residual (feet) & -1.29 & -1.39 & -1.77 & 2.76 & -0.32 & -1.26 \\
\hline $\begin{array}{l}\text { Weighted residuals standard } \\
\text { deviation (feet) }\end{array}$ & 3.01 & 3.07 & 2.92 & 3.46 & 3.62 & 2.38 \\
\hline $\begin{array}{l}\text { Root mean square error of weighted } \\
\text { residuals (feet) }\end{array}$ & 3.27 & 3.37 & 3.41 & 4.42 & 3.64 & 2.69 \\
\hline $\begin{array}{l}\text { Percent of simulated values within } \\
\text { the } 10 \text {-foot error criteria }\end{array}$ & 99 & 100 & 100 & 100 & 93 & 100 \\
\hline $\begin{array}{l}\text { Normalized standard deviation } \\
\text { (dimensionless) }\end{array}$ & 0.01 & 0.08 & 0.08 & 0.11 & 0.05 & 0.01 \\
\hline
\end{tabular}

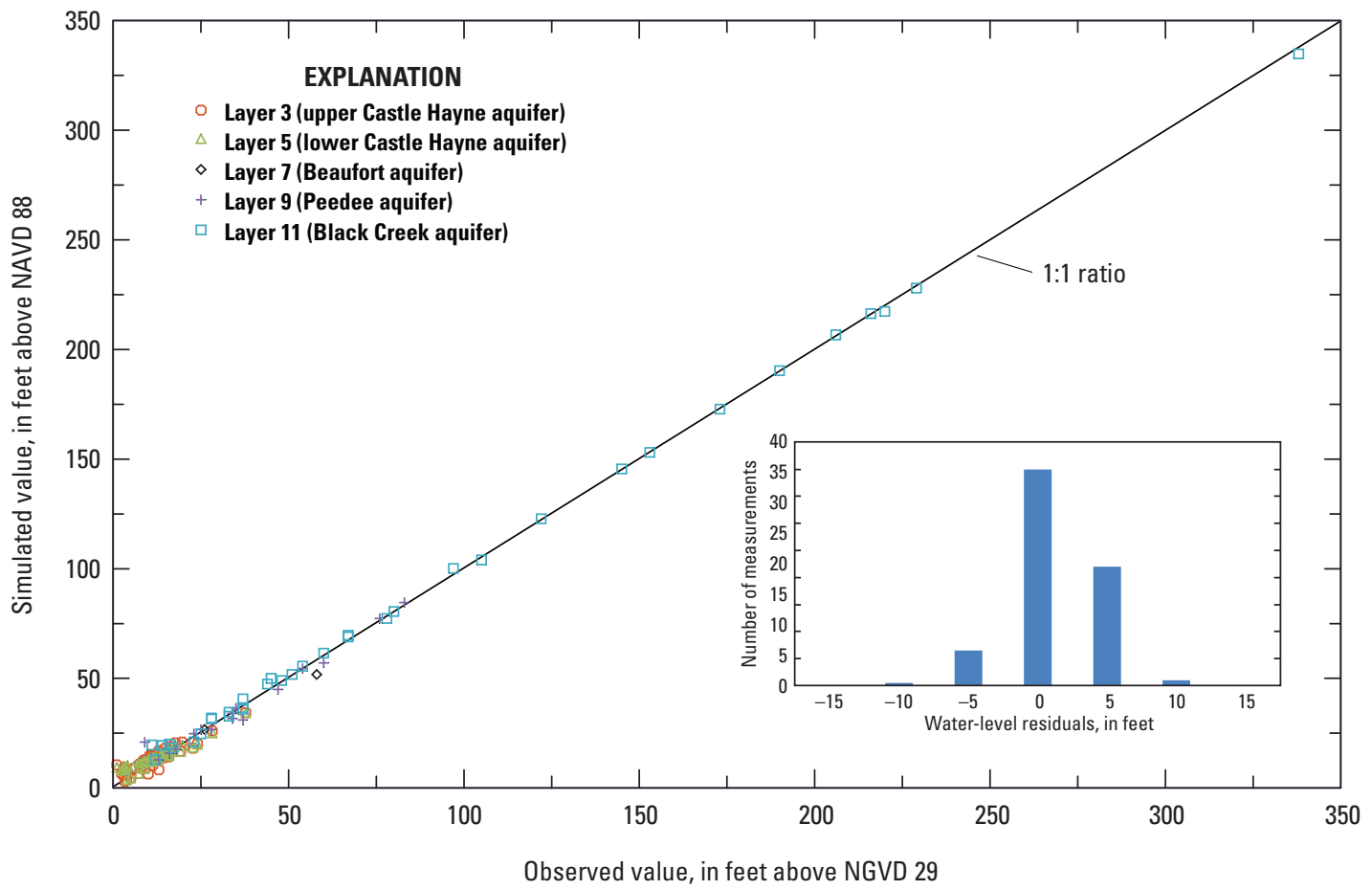

Figure 16. Observed versus simulated water-levels for predevelopment conditions. 
Table 7. Calibration statistics for simulated heads for 2004 conditions.

$[-$, no data $]$

\begin{tabular}{lcccccc}
\hline \multicolumn{1}{c}{ Calibration statistic } & All_layers & Layer $\mathbf{3}$ & Layer $\mathbf{5}$ & Layer $\mathbf{7}$ & Layer $\mathbf{9}$ & Layer $\mathbf{1 1}$ \\
\hline $\begin{array}{l}\text { Number of } \\
\text { observations }\end{array}$ & 67 & 17 & 16 & 0 & 9 & 25 \\
Range in observations (feet) & 409 & 60.5 & 60.5 & - & 47.0 & 409 \\
$\quad \begin{array}{l}\text { Minimum weighted residual (feet) } \\
\text { Maximum weighted residual (feet) }\end{array}$ & -11.8 & -0.64 & -0.60 & - & -2.69 & -11.8 \\
$\begin{array}{l}\text { Mean weighted residual (feet) } \\
\begin{array}{l}\text { Weighted residuals standard } \\
\text { deviation (feet) }\end{array}\end{array}$ & -0.07 & 0.33 & 0.37 & - & -0.67 & -0.40 \\
$\begin{array}{l}\text { Root mean square error of weighted } \\
\text { residuals (feet) }\end{array}$ & 4.65 & 0.98 & 1.01 & - & 1.77 & 7.42 \\
$\begin{array}{l}\text { Percent of simulated values within } \\
\text { the 10-foot error criteria }\end{array}$ & 97 & 1.03 & 1.08 & - & 1.89 & 7.43 \\
$\begin{array}{l}\text { Normalized standard deviation } \\
\text { (dimensionless) }\end{array}$ & 0.01 & 0.02 & 0.02 & - & 0.04 & 0.02 \\
\hline
\end{tabular}

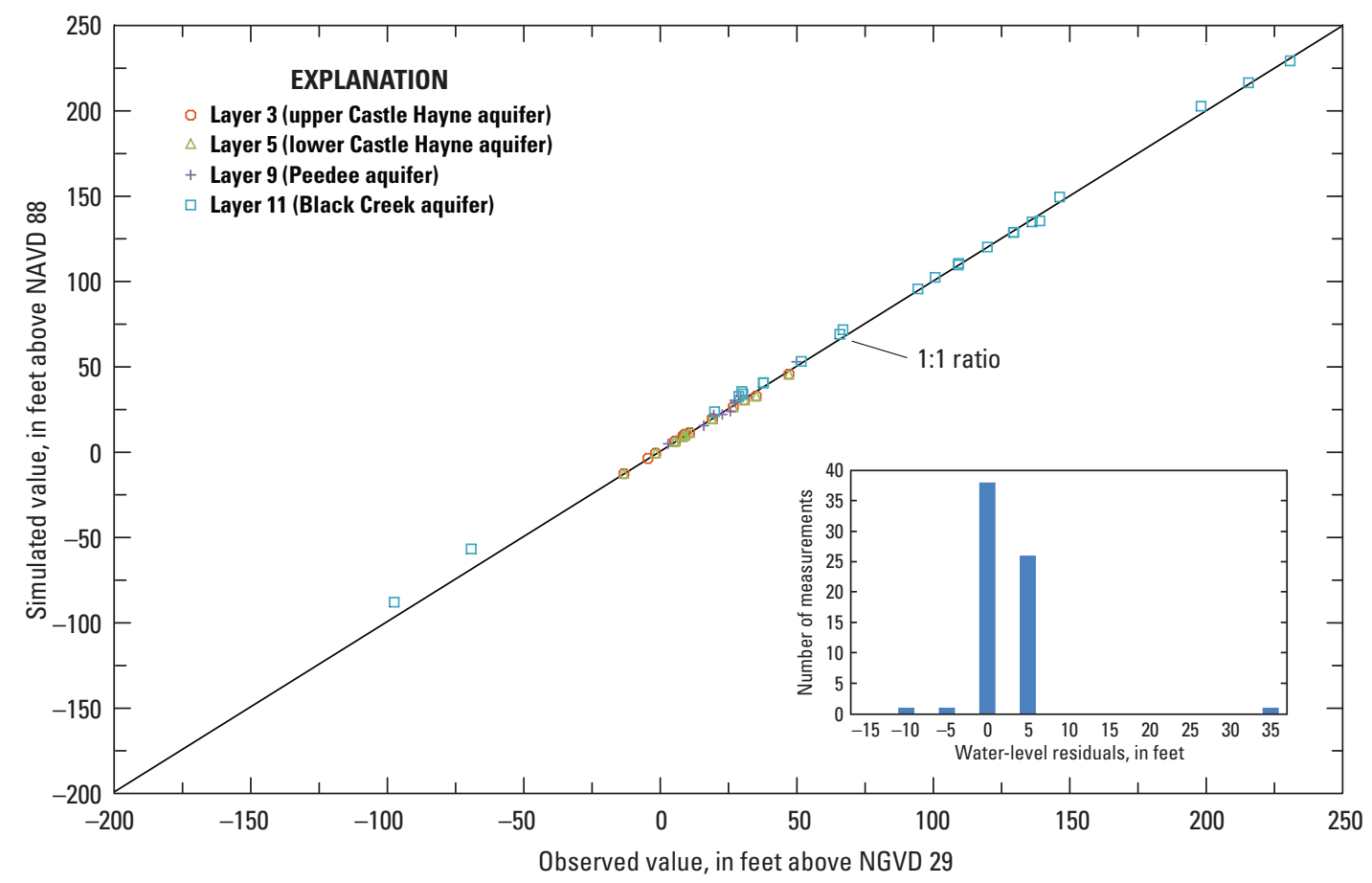

Figure 17. Observed versus simulated water levels for 2004 conditions. 
Table 8. Calibration statistics for simulated heads for 2008 conditions.

$[-$, no data $]$

\begin{tabular}{lcccccc}
\hline \multicolumn{1}{c}{ Calibration statistic } & All_layers & Layer 3 & Layer 5 & Layer 7 & Layer 9 & Layer 11 \\
\hline $\begin{array}{l}\text { Number of } \\
\text { observations }\end{array}$ & 133 & 53 & 52 & 0 & 5 & 23 \\
Range in observations (feet) & 274 & 49.7 & 49.7 & - & 90.7 & 236 \\
Minimum weighted residual (feet) & -39.4 & -21.3 & -21.5 & - & -39.4 & -14.8 \\
$\begin{array}{l}\text { Maximum weighted residual (feet) } \\
\text { Mean weighted residual (feet) }\end{array}$ & 42.0 & 13.9 & 14.9 & - & -1.3 & 42.0 \\
$\begin{array}{l}\text { Weighted residuals standard } \\
\text { deviation (feet) }\end{array}$ & 1.13 & -1.67 & -0.60 & - & -20.2 & 16.1 \\
$\begin{array}{l}\text { Root mean square error of weighted } \\
\text { residuals (feet) }\end{array}$ & 13.1 & 8.42 & 8.58 & - & 14.0 & 16.3 \\
$\begin{array}{l}\text { Percent of simulated values within } \\
\text { the 10-foot error criteria }\end{array}$ & 62 & 8.59 & 8.60 & - & 24.6 & 22.9 \\
$\begin{array}{l}\text { Normalized standard deviation } \\
\text { (dimensionless) }\end{array}$ & 0.05 & 0.17 & 0.17 & - & 0.15 & 0.07 \\
\hline
\end{tabular}

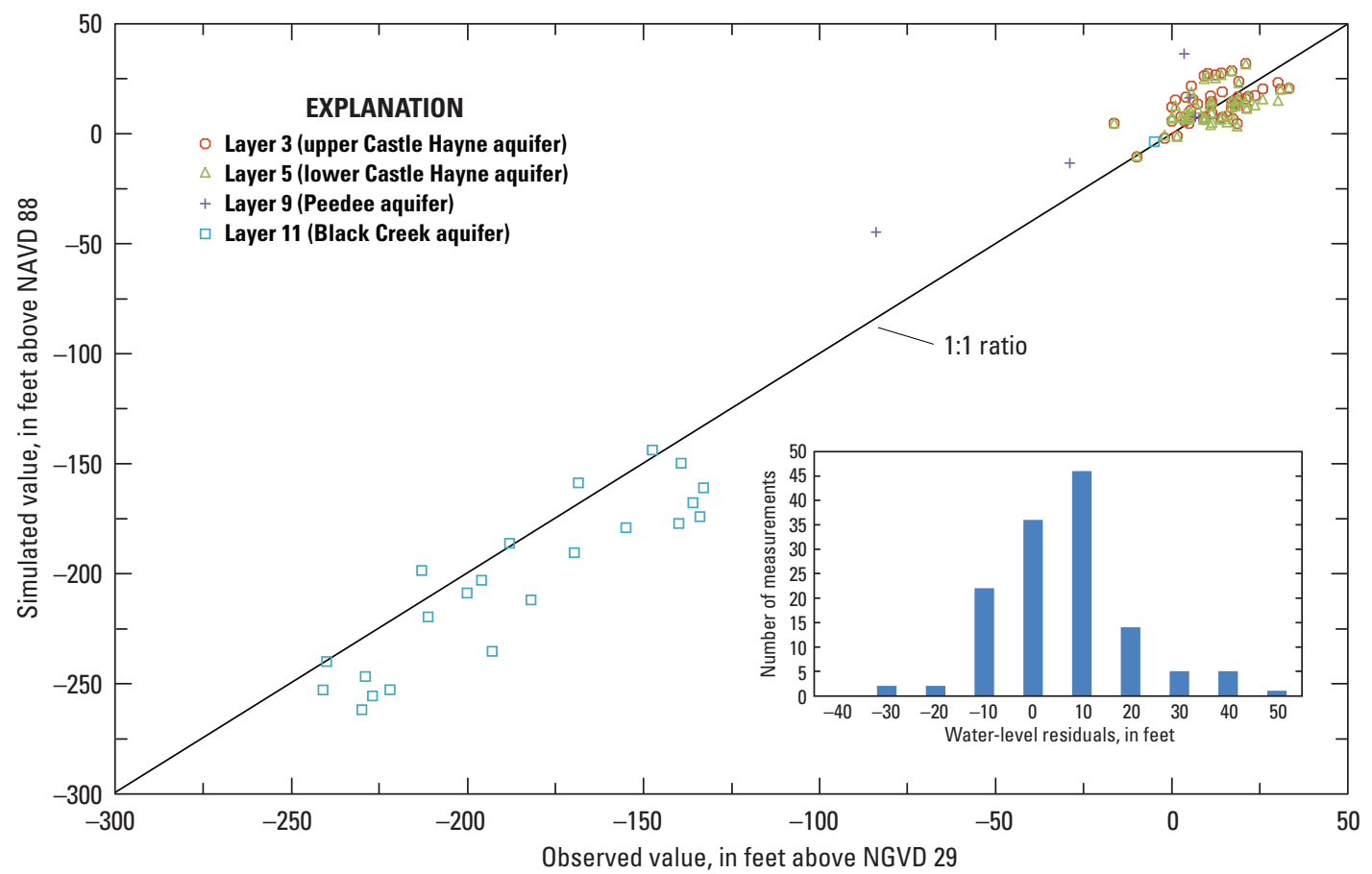

Figure 18. Observed versus simulated water levels for 2008 conditions. 
Table 9. Calibration statistics for simulated heads in wells with continuous data.

\begin{tabular}{|c|c|c|c|c|c|c|c|}
\hline Calibration statistic & All_layers & Layer 1 & Layer 3 & Layer 5 & Layer 7 & Layer 9 & Layer 11 \\
\hline Number of wells & 92 & 10 & 16 & 20 & 4 & 21 & 21 \\
\hline Number of observations & 4,392 & 521 & 805 & 839 & 180 & 1,017 & 1,030 \\
\hline Range in observations (feet) & 372 & 123 & 77.2 & 83.0 & 41.4 & 105 & 372 \\
\hline Minimum weighted residual (feet) & -112 & -15.8 & -35.9 & -79.2 & -0.12 & -53.3 & -112 \\
\hline Maximum weighted residual (feet) & 27.1 & 12.2 & 21.2 & 23.7 & 12.0 & 17.5 & 27.1 \\
\hline Mean weighted residual (feet) & -0.92 & 0.83 & 0.61 & -0.71 & 5.03 & -3.29 & -1.88 \\
\hline $\begin{array}{l}\text { Weighted residuals standard devia- } \\
\text { tion (feet) }\end{array}$ & 8.16 & 4.53 & 6.46 & 10.06 & 4.39 & 8.20 & 8.53 \\
\hline $\begin{array}{l}\text { Root mean square error of weighted } \\
\text { residuals (feet) }\end{array}$ & 8.21 & 4.61 & 6.49 & 10.09 & 6.68 & 8.84 & 8.73 \\
\hline $\begin{array}{l}\text { Percent of simulated values witin } \\
\text { the } 10 \text {-foot error criteria }\end{array}$ & 86 & 94 & 90 & 89 & 83 & 82 & 82 \\
\hline $\begin{array}{l}\text { Normalized standard deviation } \\
\text { (dimensionless) }\end{array}$ & 0.02 & 0.04 & 0.08 & 0.12 & 0.11 & 0.08 & 0.02 \\
\hline
\end{tabular}

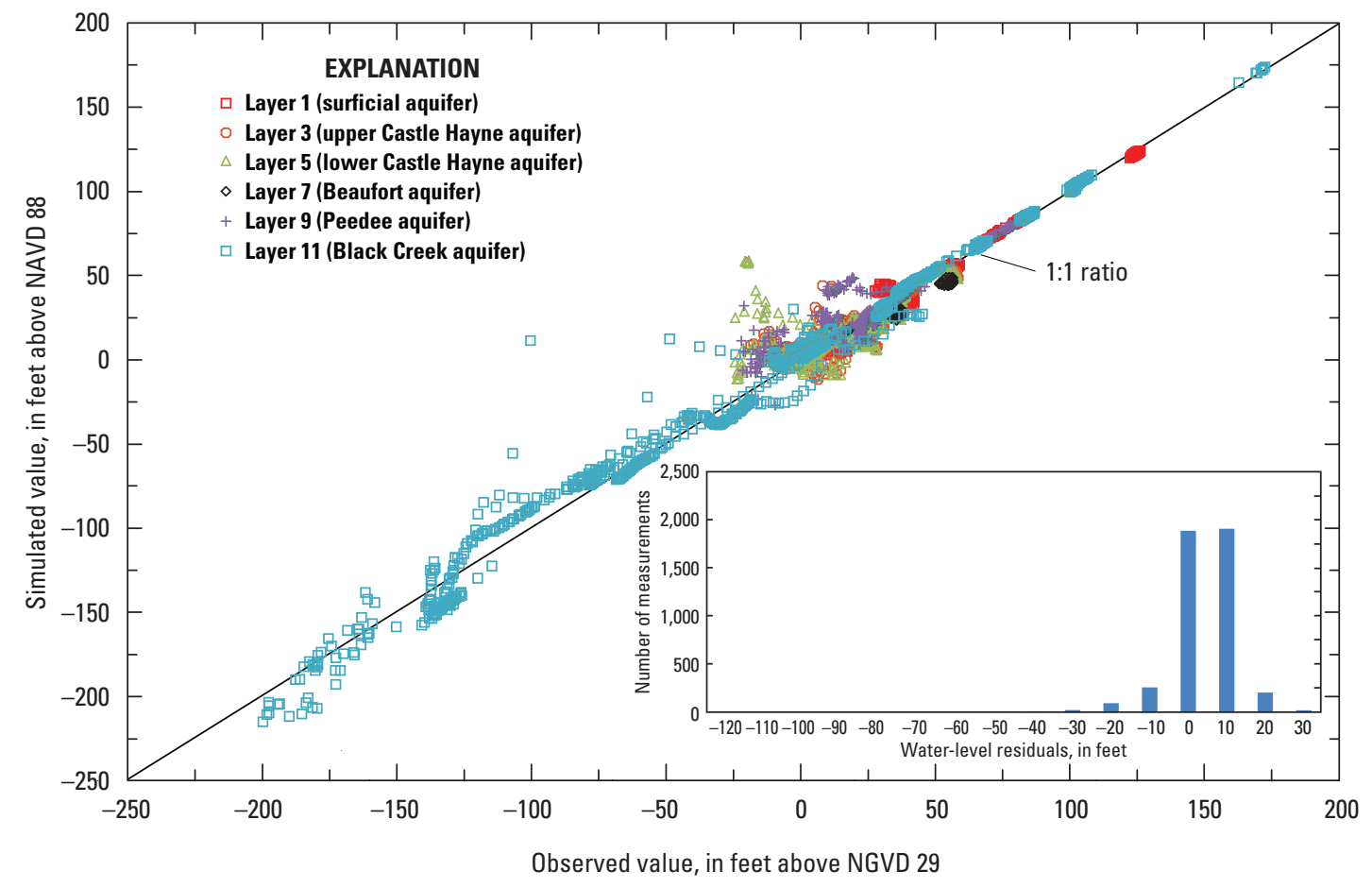

Figure 19. Observed versus simulated water levels for wells with continuous data. 
greatest observed drawdown and could cause the slightly negative mean residual values. For all layers, at least one of the head-residual calibration criteria was met (mean residual close to 0 , majority of residuals less than $10 \mathrm{ft}$, or standard deviation divided by the range of observed values less than 0.1 in tables 6-9). For most layers, the majority of head residuals were within the 10-ft error criteria with the exception of the Peedee and Black Creek aquifers (model layers 9 and 11, respectively). Additionally, the mean residual value was slightly negative for the Black Creek aquifer for three of the four comparison periods. However, the mean residual for all other layers was almost always less than $4 \mathrm{ft}$ and often closer to zero. For all aquifers, the normalized standard deviation criteria were always met (tables 6-9).

Spatial bias is undesirable and can qualitatively be assessed by plotting the residuals on maps. For the predevelopment period (stress period 1 of the model), water-level data were available for the upper Castle Hayne (model layer 3), lower Castle Hayne (model layer 5), Beaufort (model layer 7), Peedee (model layer 9), and Black Creek (model layer 11) aquifers; these residuals are plotted in figure 20. As stated previously in the description of the scatter plot (fig. 16), most of the maps show no spatial pattern of positive or negative residuals, except for figure $20 D$ (model layer 9 - Peedee aquifer) in which there are high negative residuals (simulated water levels are higher than observed water levels) inland and positive residuals near the coast to the northeast of the study area. Maps of residuals for the fourth quarter of 2004 (stress period 48) for the upper Castle Hayne (model layer 3), lower Castle Hayne (model layer 5), Beaufort (model layer 7), Peedee (model layer 9), and Black Creek aquifers (model layer 11) are plotted in figure 21. Most of the observed waterlevel data for the 2004 stress period were monitored outside of Onslow County; however, most of the data collected in the study area for the 2004 stress period (and 2008 stress period) are incorporated into the continuous dataset because multiple measurements are associated with those wells rather than individual measurements. For all the aquifers, there is spatial bias because simulated water levels are mostly higher than the observed values (negative residuals). However, in areas outside the study area and near the boundaries, the spatial bias and higher residuals are not critical to the calibration.

Maps of residuals for the fourth quarter of 2008 (stress period 64) for the upper Castle Hayne (model layer 3), lower Castle Hayne (model layer 5), Beaufort (model layer 7), Peedee (model layer 9), and Black Creek aquifers (model layer 11) are plotted in figure 22. For this calibration period, much of the observed data are within Onslow County, where the grid resolution is fine and the observations were assigned much larger weights for the parameter estimation process. Based on the illustrations, there is no apparent spatial bias in the residuals, with the exception of the Peedee aquifer, where most of the data are within the cone of depression, and most of the residuals are negative (fig. 22D). As discussed previously, the decision was made not to adjust the reported groundwater withdrawals and to constrain the hydraulic conductivity with the aquifer test data during the calibration process. If groundwater withdrawals are increased, the result would be an increase in simulated drawdown and a better model fit to observed drawdown in the cone of depression for this stress period.

The 92 wells that had continuous or semi-continuous data are spread throughout the model area and are in the surficial (model layer 1), upper Castle Hayne (model layer 3), lower Castle Hayne (model layer 5), Beaufort (model layer 7), Peedee (model layer 9), and Black Creek aquifers (model layer 11). Maps showing the mean residuals for wells in these aquifers are provided in figure 23. For the calibration period, there is no apparent spatial bias in the residuals for the surficial and upper and lower Castle Hayne aquifers (fig. 23A-C). For the Beaufort aquifer, most of the mean residuals are slightly positive (fig. 23D). For the Peedee and Black Creek aquifers, most of the mean residuals are slightly negative (fig. 23E-F); however, all residuals are within the calibration criteria. 


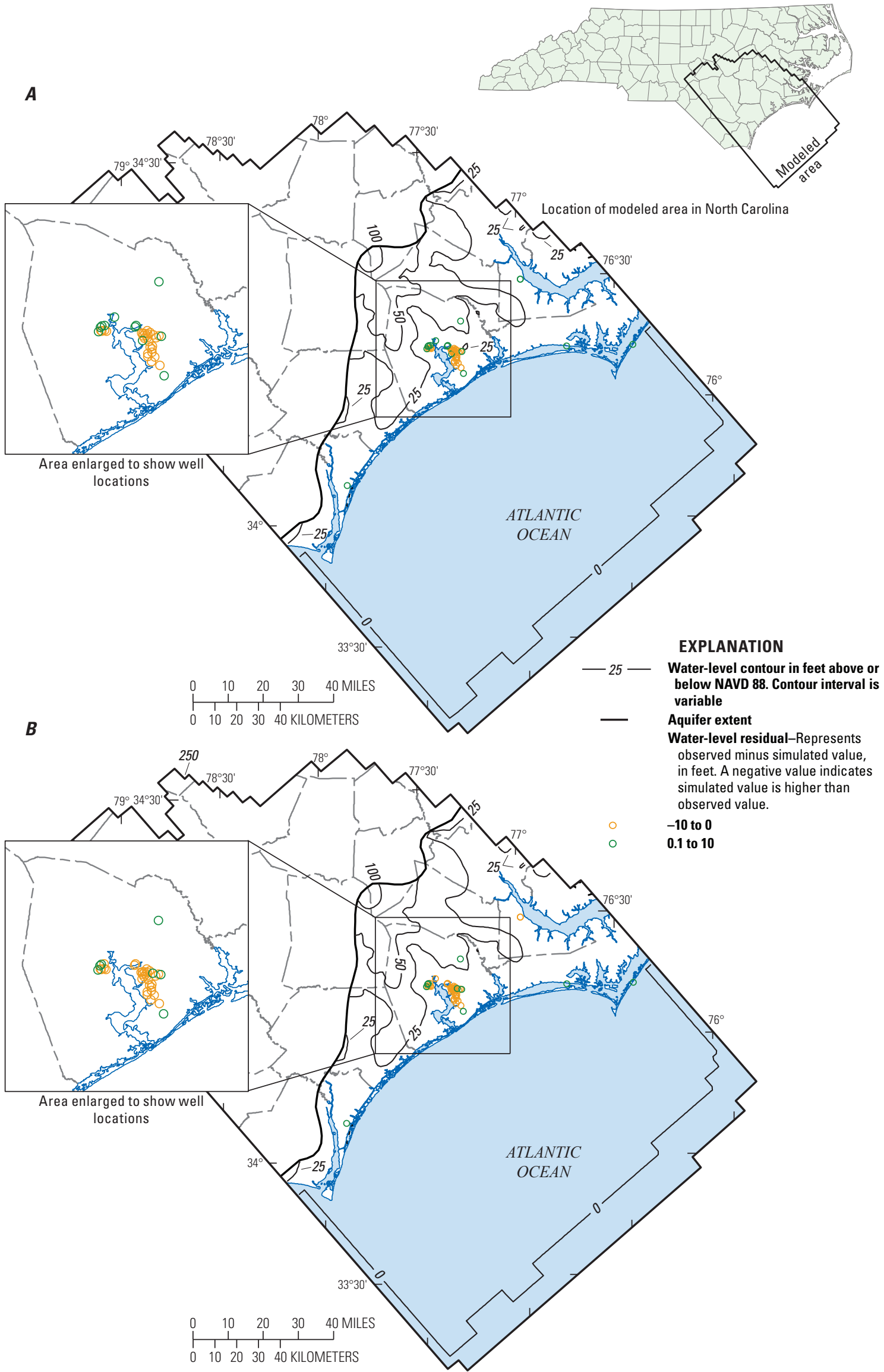

Figure 20. Map showing simulated potentiometric surfaces and water-level residuals for the predevelopment time period for the (A) upper Castle Hayne (model layer 3), (B) lower Castle Hayne (model layer 5), (C) Beaufort (model layer 7), (D) Peedee (model layer 9), and (E) Black Creek aquifers (model layer 11). 


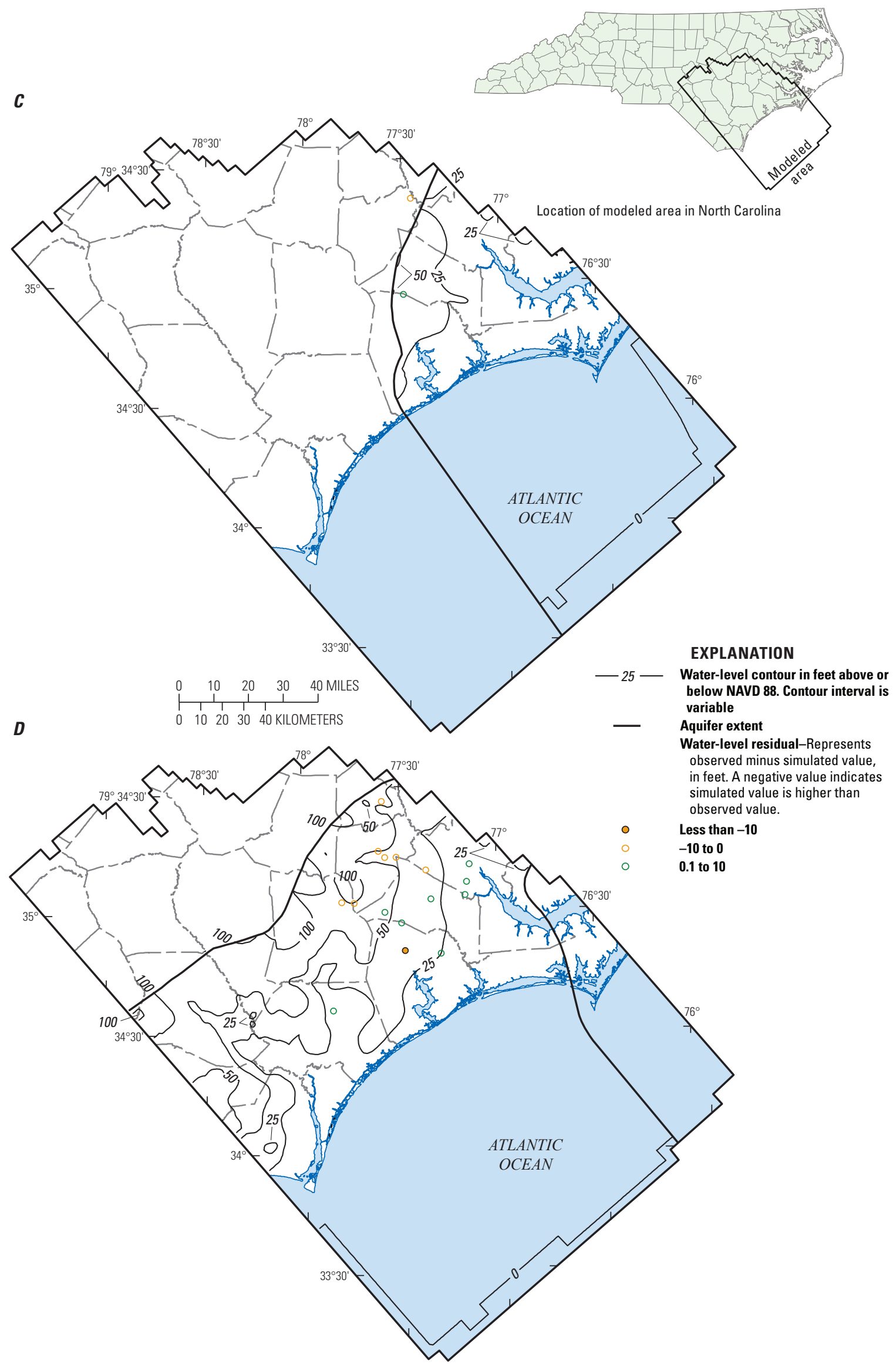

Figure 20. Map showing simulated potentiometric surfaces and water-level residuals for the predevelopment time period for the $(A)$ upper Castle Hayne (model layer 3$),(B)$ lower Castle Hayne (model layer 5$),(C)$ Beaufort (model layer 7 ), (D) Peedee (model layer 9), and (E) Black Creek aquifers (model layer 11).-Continued 


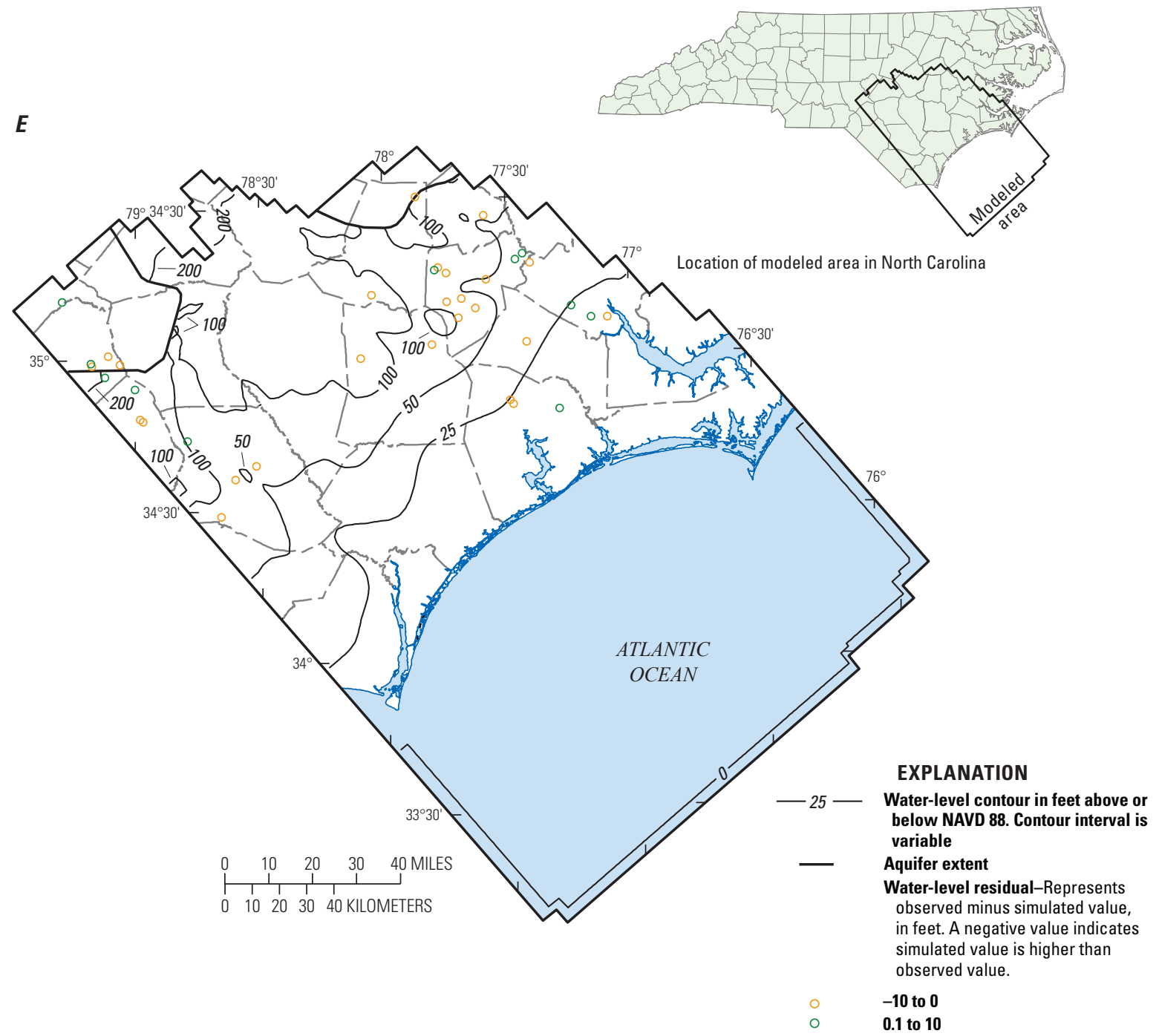

Figure 20. Map showing simulated potentiometric surfaces and water-level residuals for the predevelopment time period for the $(A)$ upper Castle Hayne (model layer 3), (B) lower Castle Hayne (model layer 5), (C) Beaufort (model layer 7), (D) Peedee (model layer 9), and (E) Black Creek aquifers (model layer 11).-Continued 
$\boldsymbol{A}$
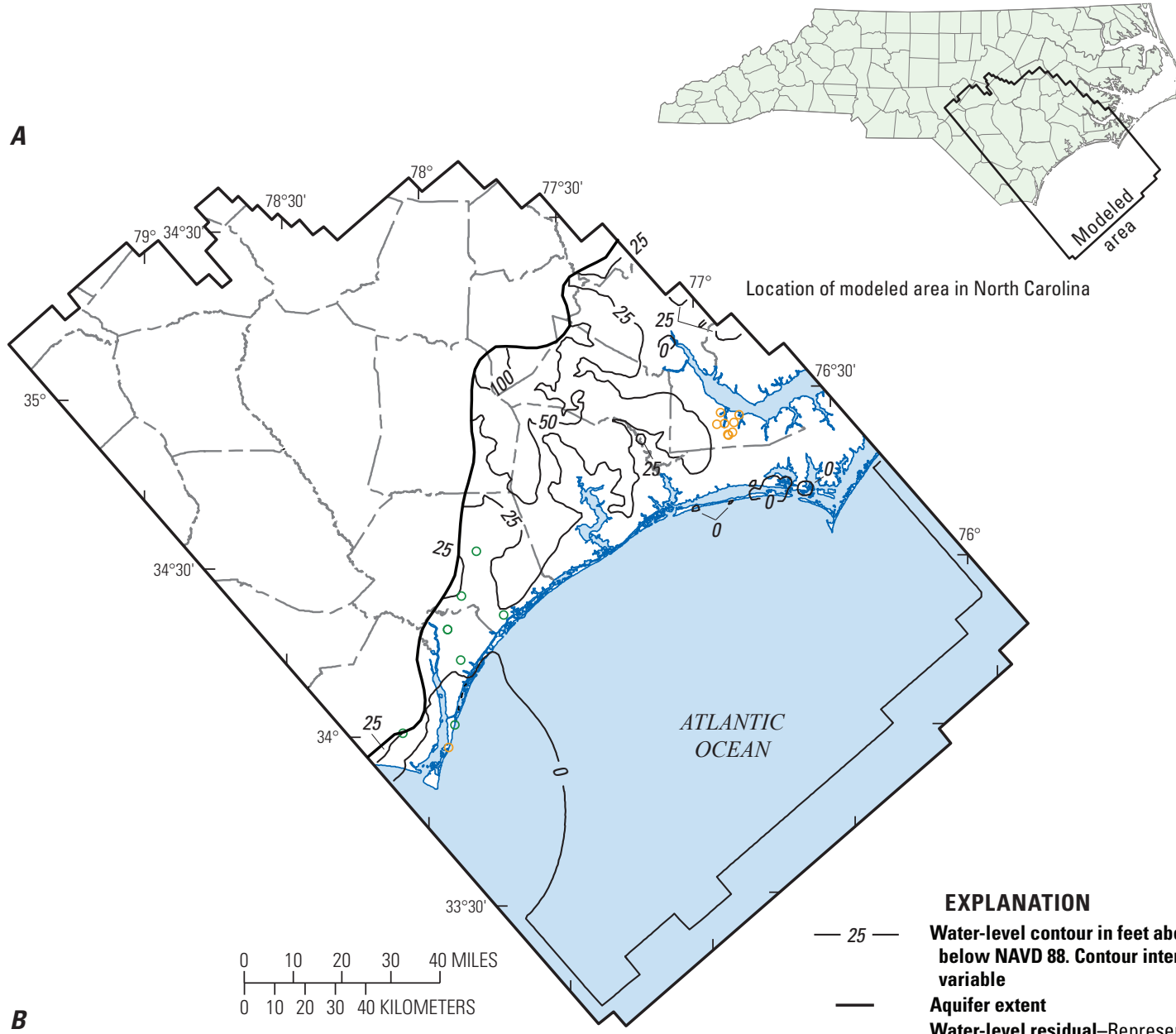

$77^{\circ} 30^{\circ}$<smiles>CCCCC1CCCCC1(C)C</smiles>

$77^{\circ}$ Location of modeled area in North Carolina

$B$

\begin{tabular}{cccccc}
\hline & 1 & 1 & & & \\
0 & 10 & 20 & 30 & 40 KILOMETERS
\end{tabular}

EXPLANATION

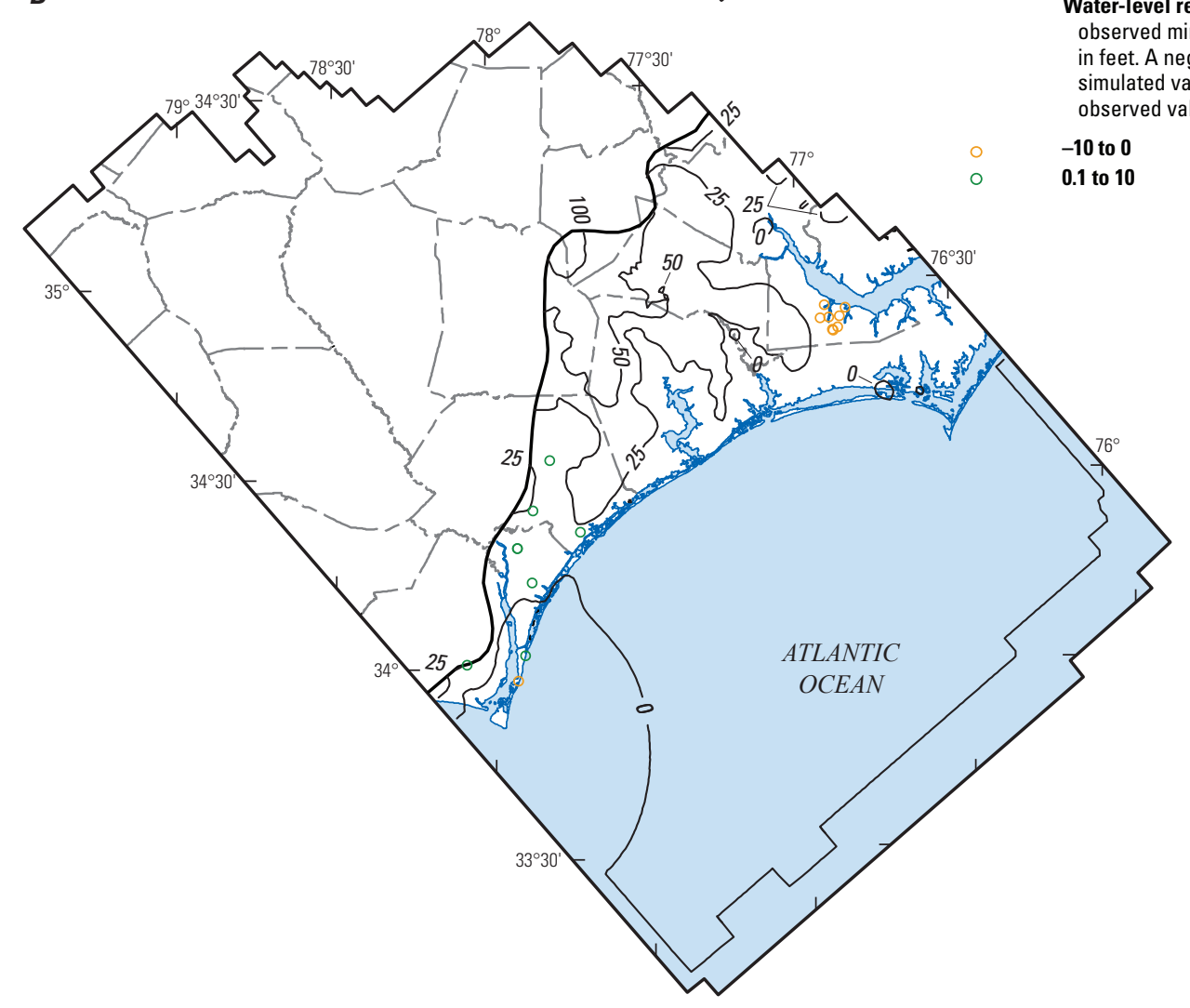

below NAVD 88. Contour interval variable

Aquifer extent

Water-level residual-Represents bserved minus simulated value, feet. A negative value indicates mulated value is higher than bserved value.

Figure 21. Map showing simulated potentiometric surfaces and water-level residuals for the 2004 time period for the $(A)$ upper Castle Hayne (model layer 3), (B) lower Castle Hayne (model layer 5), Beaufort (model layer 7), (D) Peedee (model layer 9), and (E) Black Creek aquifers (model layer 11). 


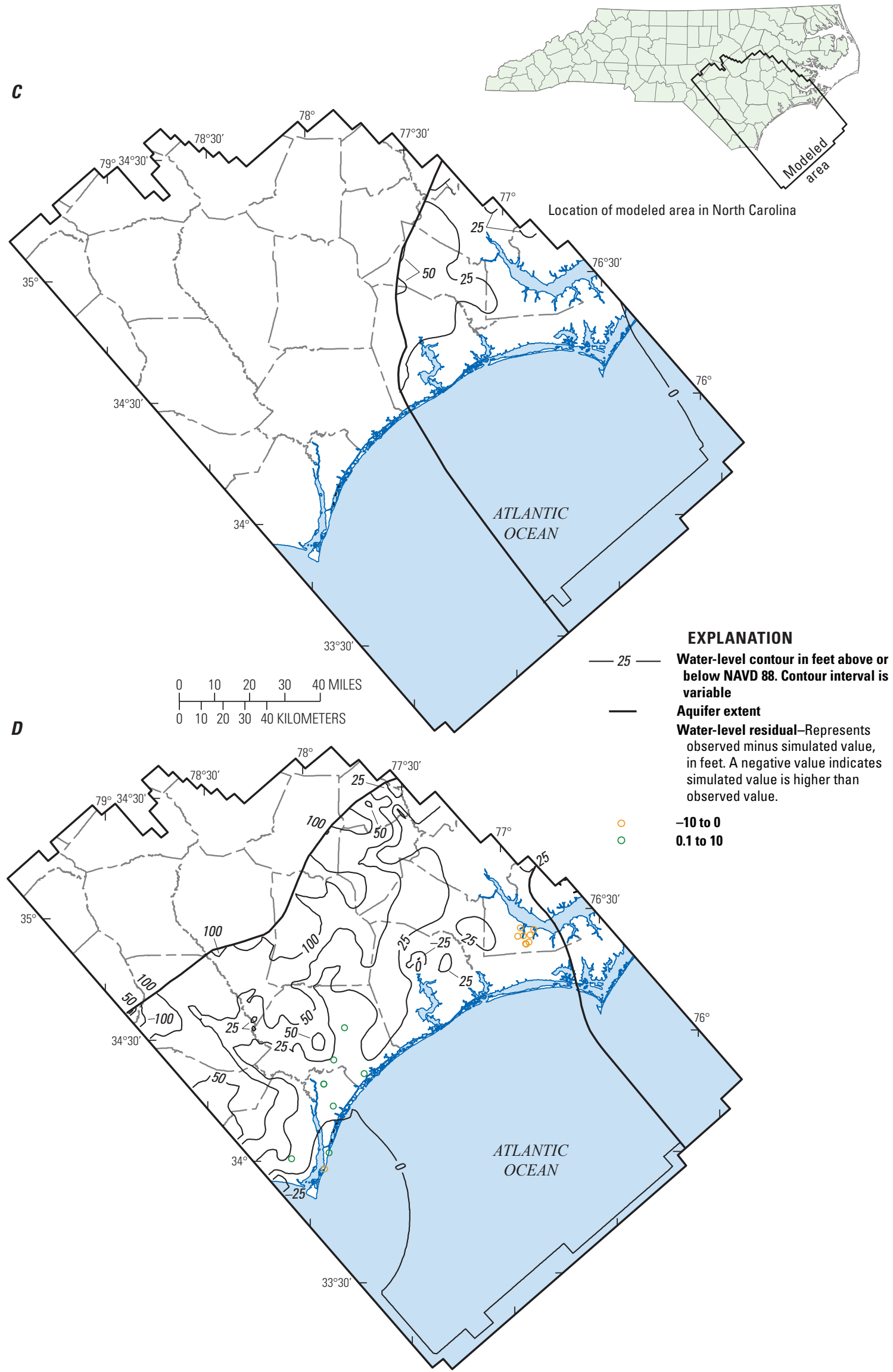

Figure 21. Map showing simulated potentiometric surfaces and water-level residuals for the 2004 time period for the $(A)$ upper Castle Hayne (model layer 3), (B) lower Castle Hayne (model layer 5), Beaufort (model layer 7), (D) Peedee (model layer 9), and (E) Black Creek aquifers (model layer 11).—Continued 


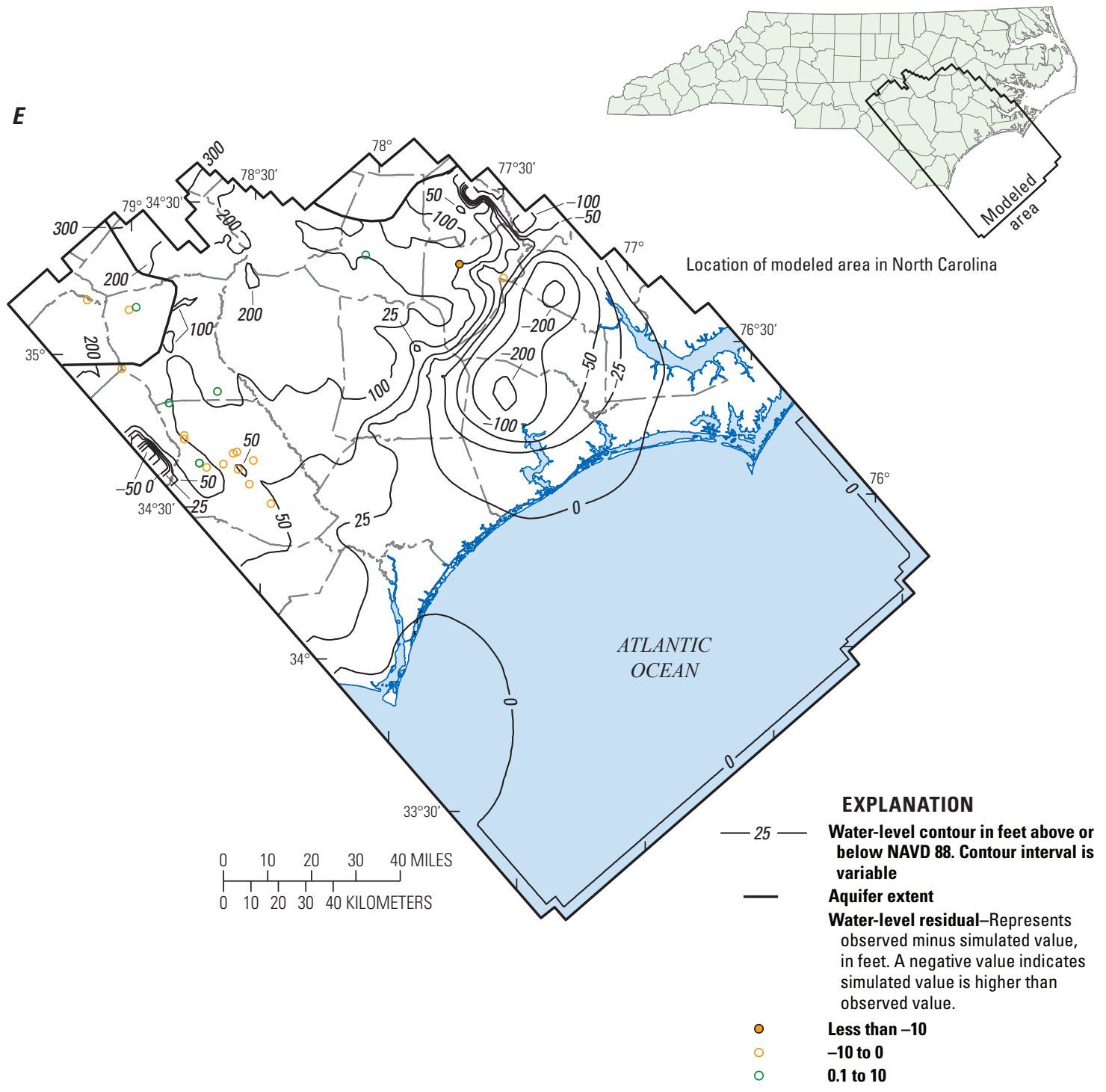

Figure 21. Map showing simulated potentiometric surfaces and water-level residuals for the 2004 time period for the $(A)$ upper Castle Hayne (model layer 3 ), (B) lower Castle Hayne (model layer 5 ), Beaufort (model layer 7), (D) Peedee (model layer 9), and (E) Black Creek aquifers (model layer 11). - Continued 


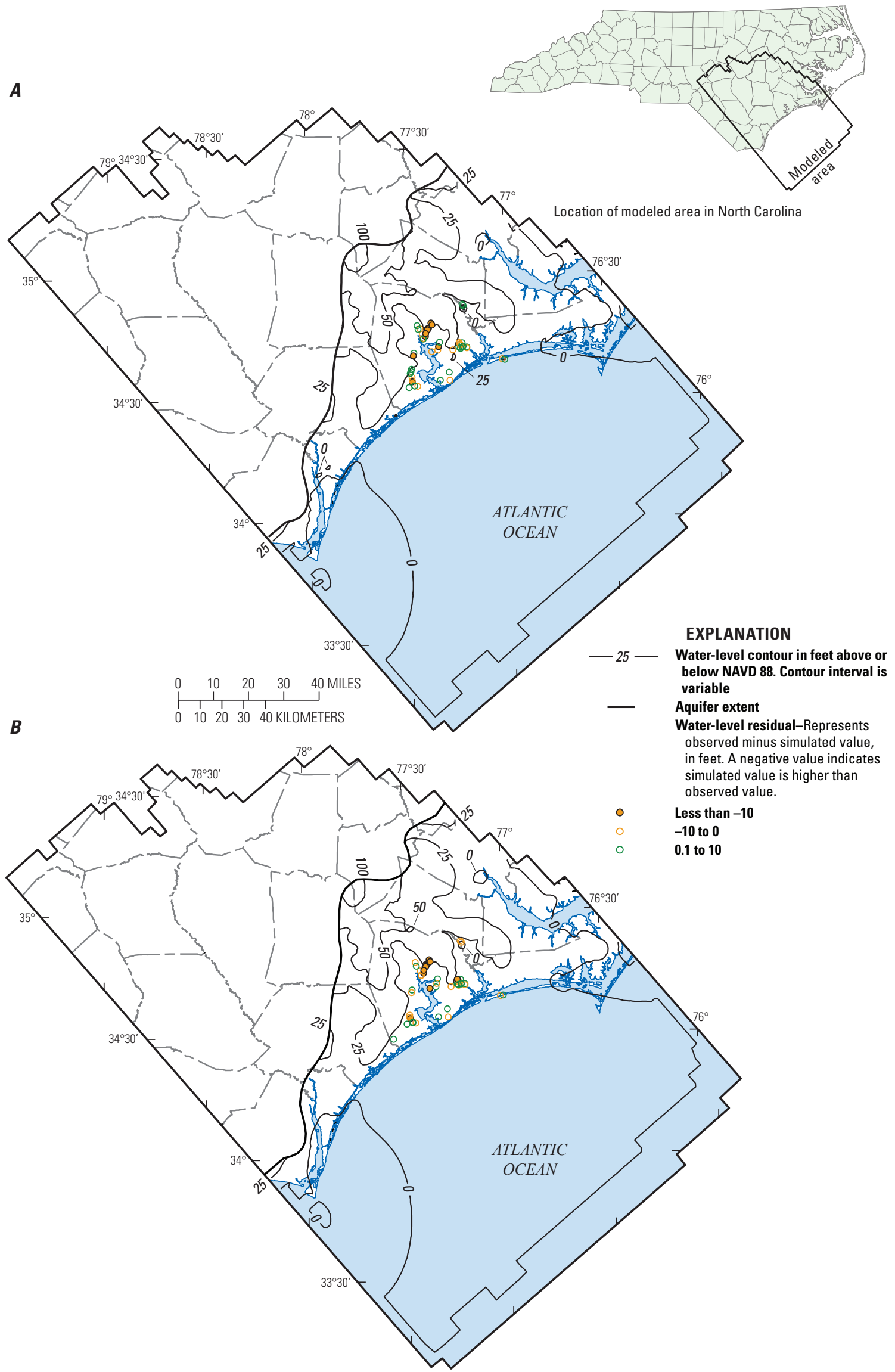

Figure 22. Map showing simulated potentiometric surfaces and residuals for the 2008 time period for $(A)$ upper Castle Hayne (model layer 3), (B) lower Castle Hayne (model layer 5), (C) Beaufort (model layer 7), (D) Peedee (model layer 9), and (E) Black Creek aquifers (model layer 11). 


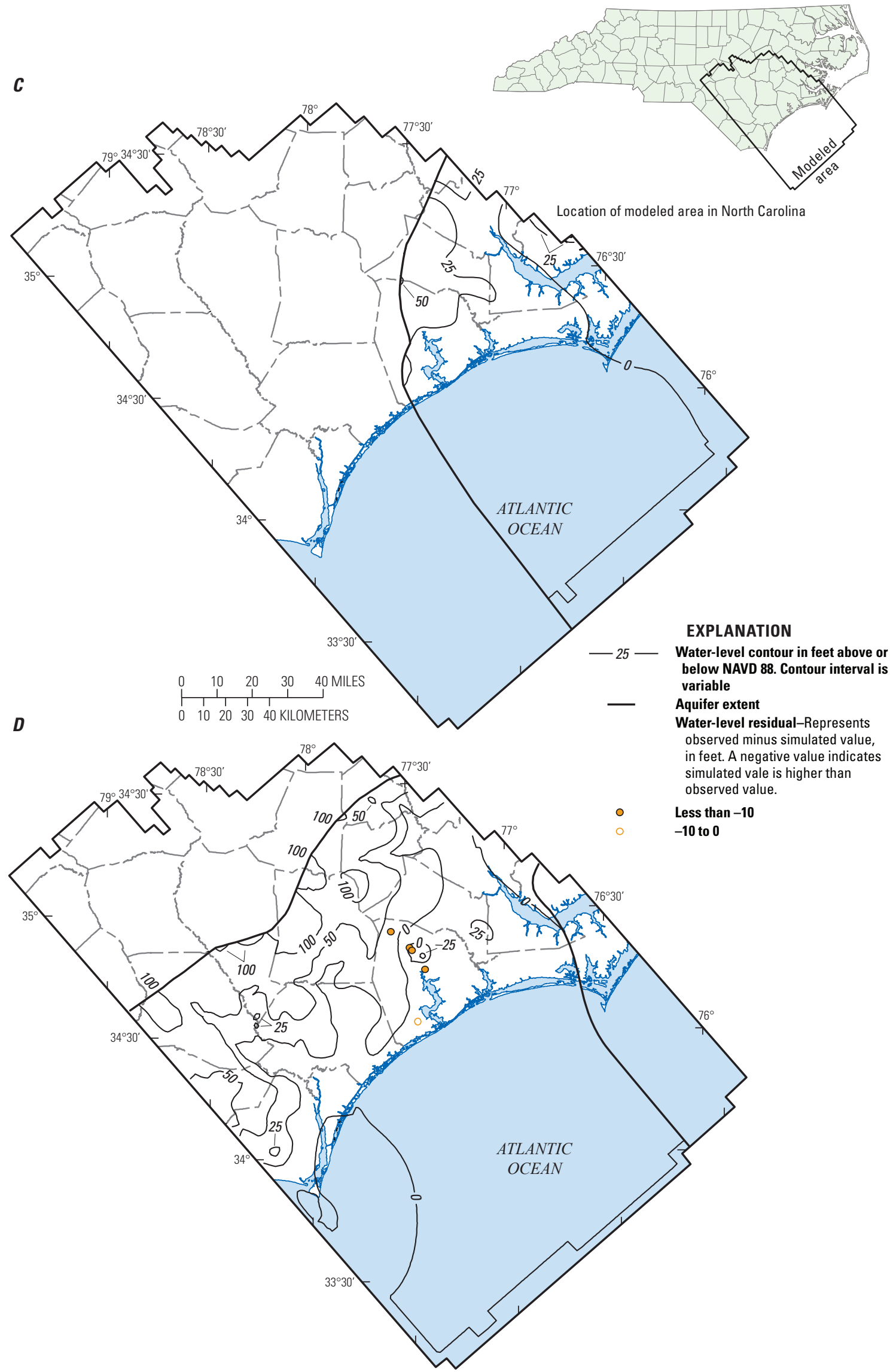

Figure 22. Map showing simulated potentiometric surfaces and residuals for the 2008 time period for $(A)$ upper Castle Hayne (model layer 3), (B) lower Castle Hayne (model layer 5), (C) Beaufort (model layer 7), (D) Peedee (model layer 9), and (E) Black Creek aquifers (model layer 11).-Continued 


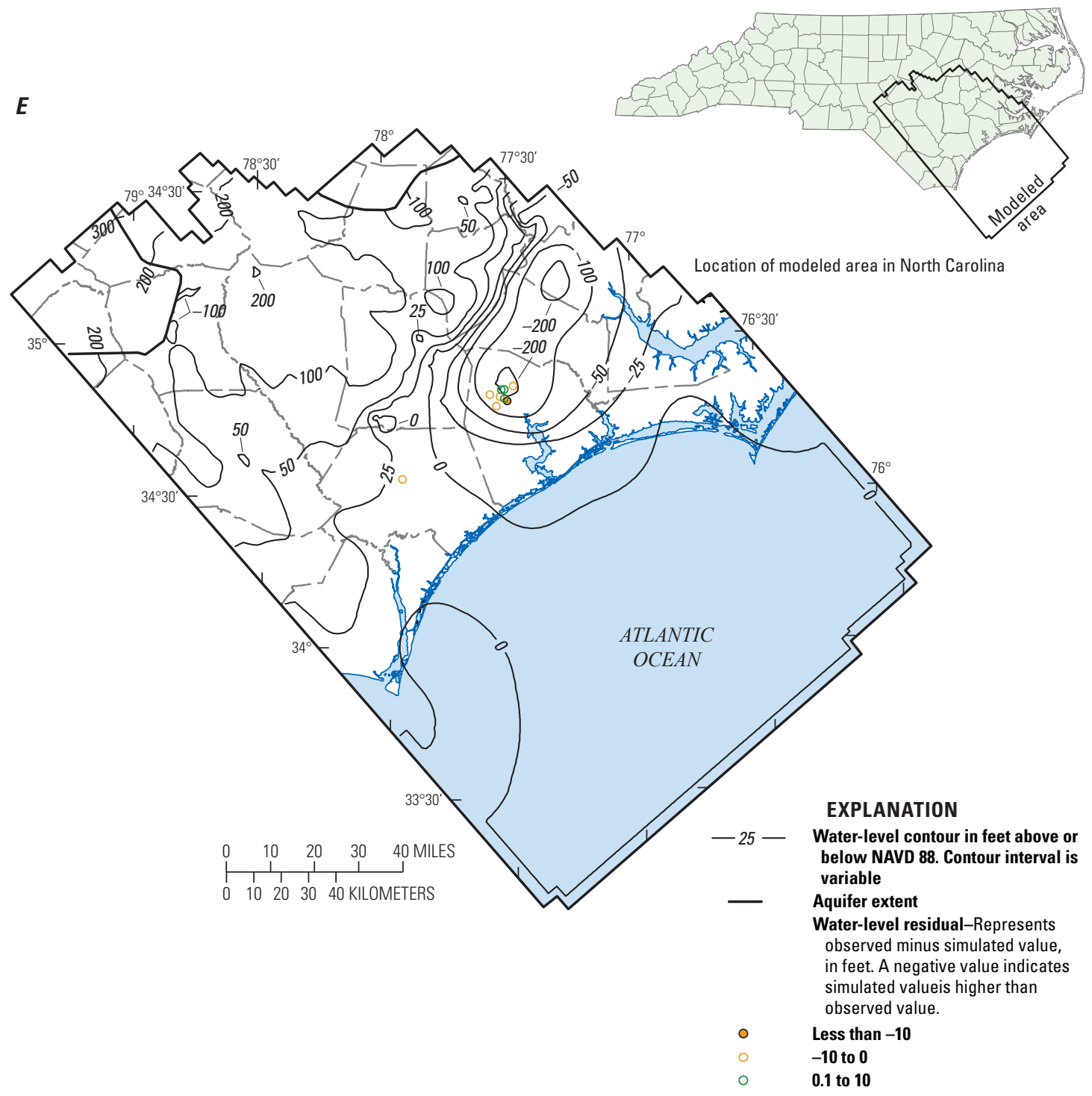

Figure 22. Map showing simulated potentiometric surfaces and residuals for the 2008 time period for $(A)$ upper Castle Hayne (model layer 3), (B) lower Castle Hayne (model layer 5), (C) Beaufort (model layer 7), $(D)$ Peedee (model layer 9), and (E) Black Creek aquifers (model layer 11).-Continued 


\section{$\boldsymbol{A}$}
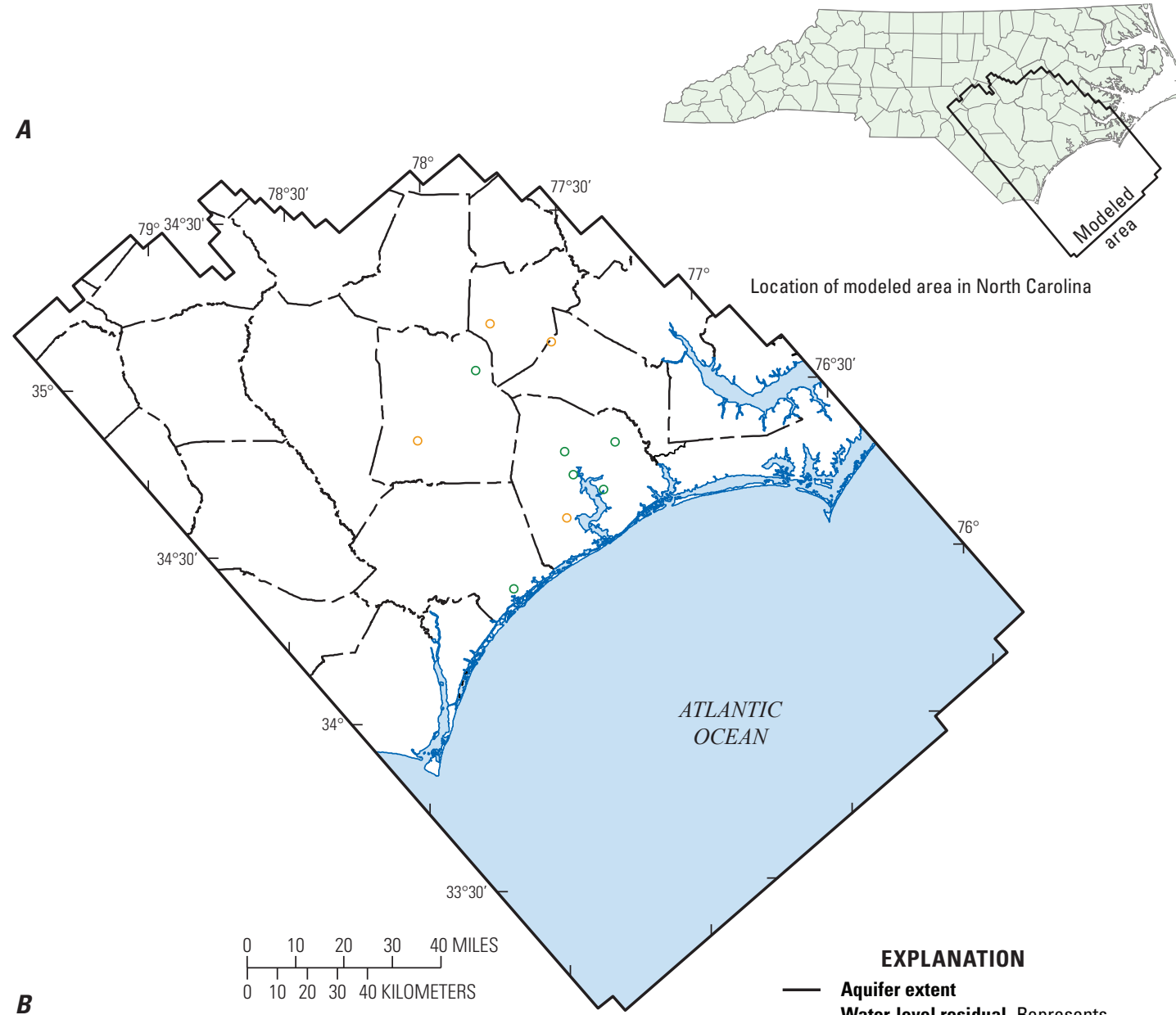

Location of modeled area in North Carolina

$\boldsymbol{B}$

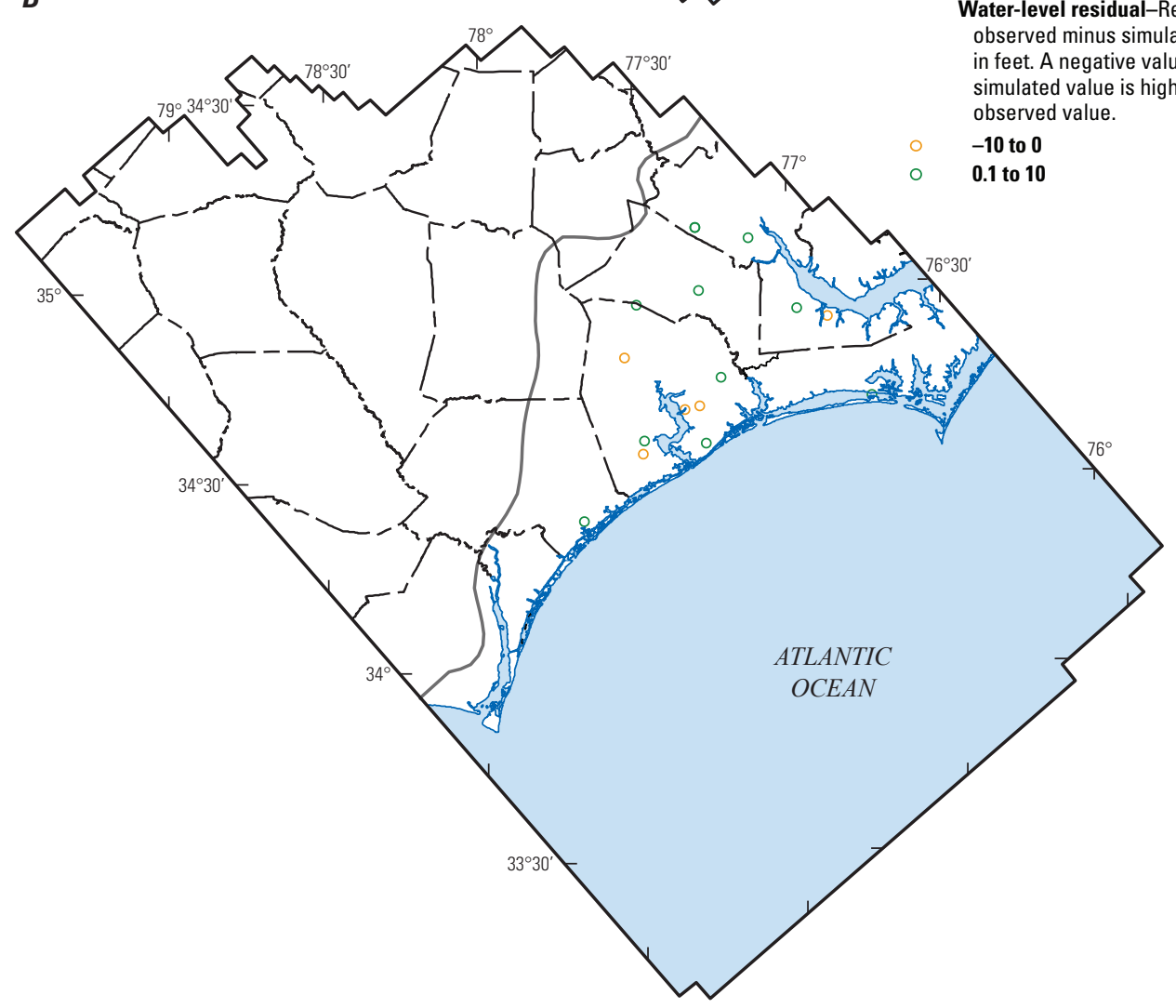

Figure 23. Map showing residuals for the continuous recorder wells for the $(A)$ surficial (model layer 1), $(B)$ upper Castle Hayne (model layer 3), (C) lower Castle Hayne (model layer 5), (D) Beaufort (model layer 7), (E) Peedee (model layer 9), and (F) Black Creek aquifers (model layer 11). 


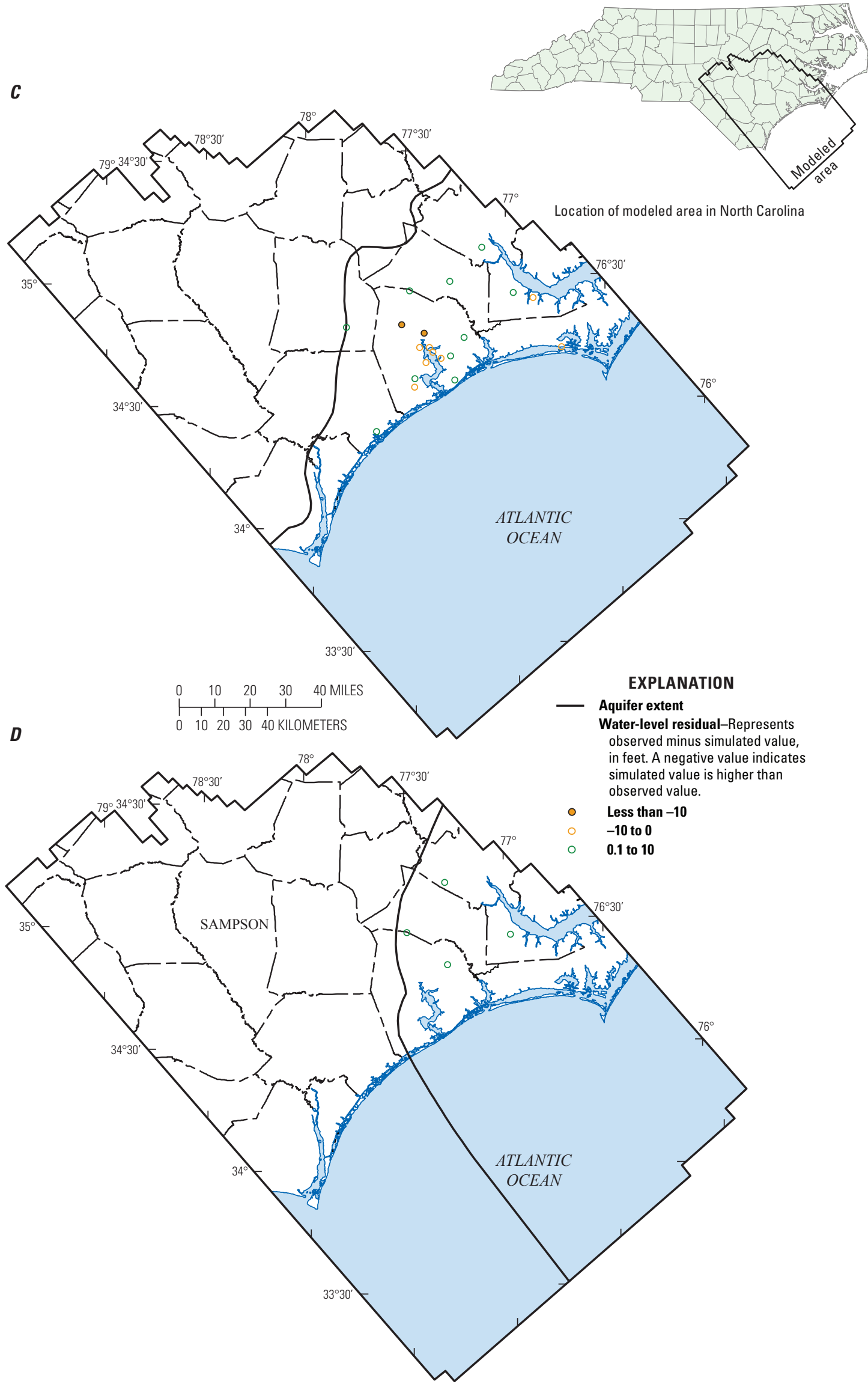

Figure 23. Map showing residuals for the continuous recorder wells for the $(A)$ surficial (model layer 1$),(B)$ upper Castle Hayne (model layer 3), (C) lower Castle Hayne (model layer 5), (D) Beaufort (model layer 7), (E) Peedee (model layer 9), and (F) Black Creek aquifers (model layer 11).-Continued 


\section{$\boldsymbol{E}$}
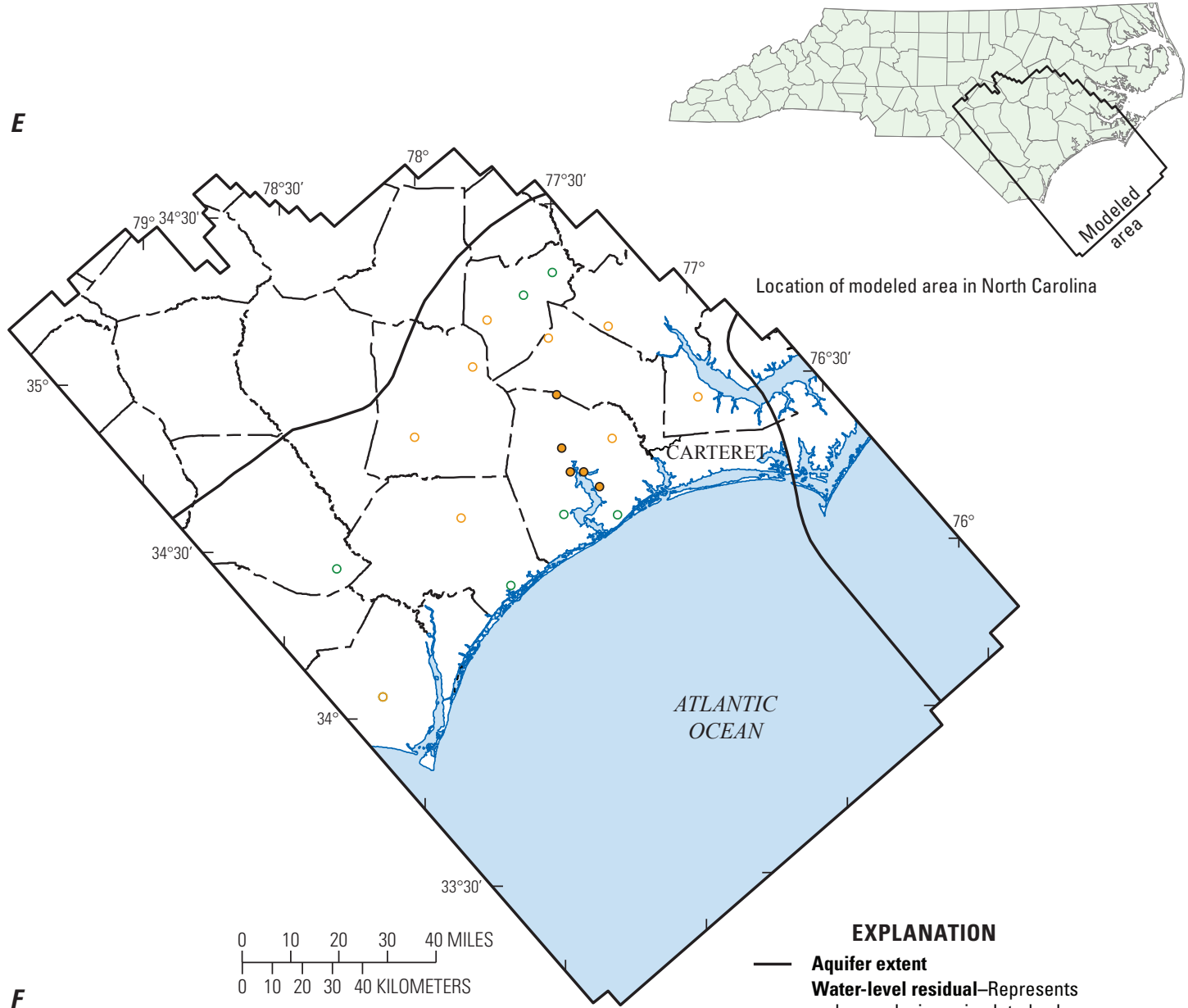

Location of modeled area in North Carolina

$\boldsymbol{F}$

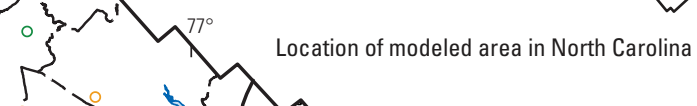

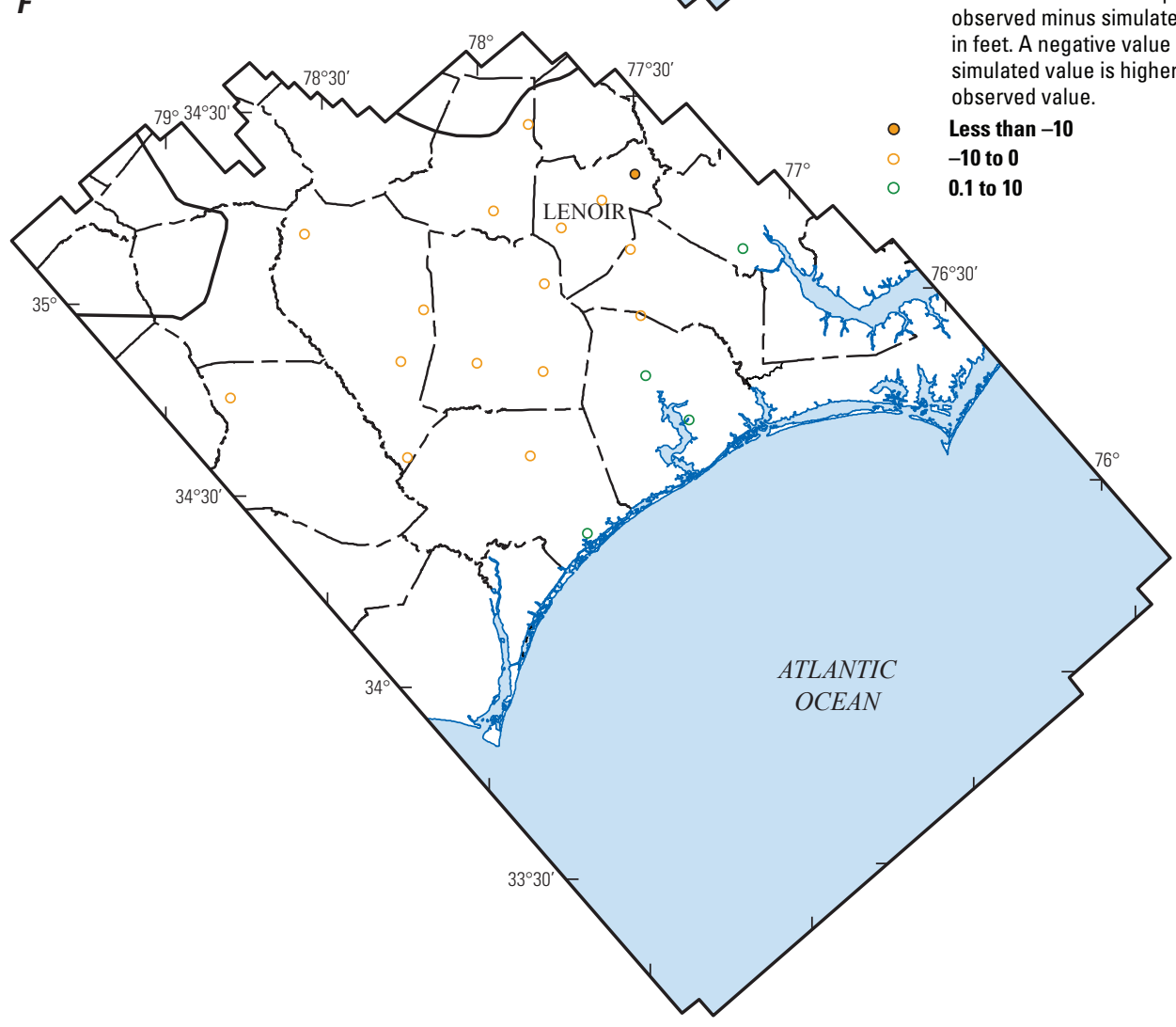

Figure 23. Map showing residuals for the continuous recorder wells for the $(A)$ surficial (model layer 1), $(B)$ upper Castle Hayne (model layer 3), (C) lower Castle Hayne (model layer 5), (D) Beaufort (model layer 7), (E) Peedee (model layer 9), and (F) Black Creek aquifers (model layer 11).-Continued 
In order to show how the simulations fit through time, selected hydrographs of observed and simulated water levels are provided in figures 24-27. The hydrographs of observed (red) and simulated (blue) water levels at an observation well are plotted with various scaled axes to show the temporal and water-level range of the particular well.

The simulated water levels for the three wells in the upper Castle Hayne aquifer fit the observed water levels fairly well, in that the difference between the simulated and observed water levels often is less than $4 \mathrm{ft}$ (fig. 24). The trends in water levels and the seasonal variation are close to the observed data (fig. 24). The simulated water levels for the five wells in the lower Castle Hayne aquifer (fig. 25) fit the observed water levels fairly well, matching overall trend and seasonal variation. The hydrographs for wells in the Beaufort (fig. 26) and Peedee aquifers (fig. 27) generally show simulated water levels within $10 \mathrm{ft}$ of the observed water levels. The Black Creek aquifer has the greatest drawdown over time (fig. 28), thus the vertical axis covers a much greater range in water level than what is shown in previous figures for other aquifers. Overall both the trend in water levels and seasonal fluctuations are similar; however, the simulated and observed water levels for the Black Creek aquifer often differ by more than $10 \mathrm{ft}$ (fig. 28). 
Well ON-295
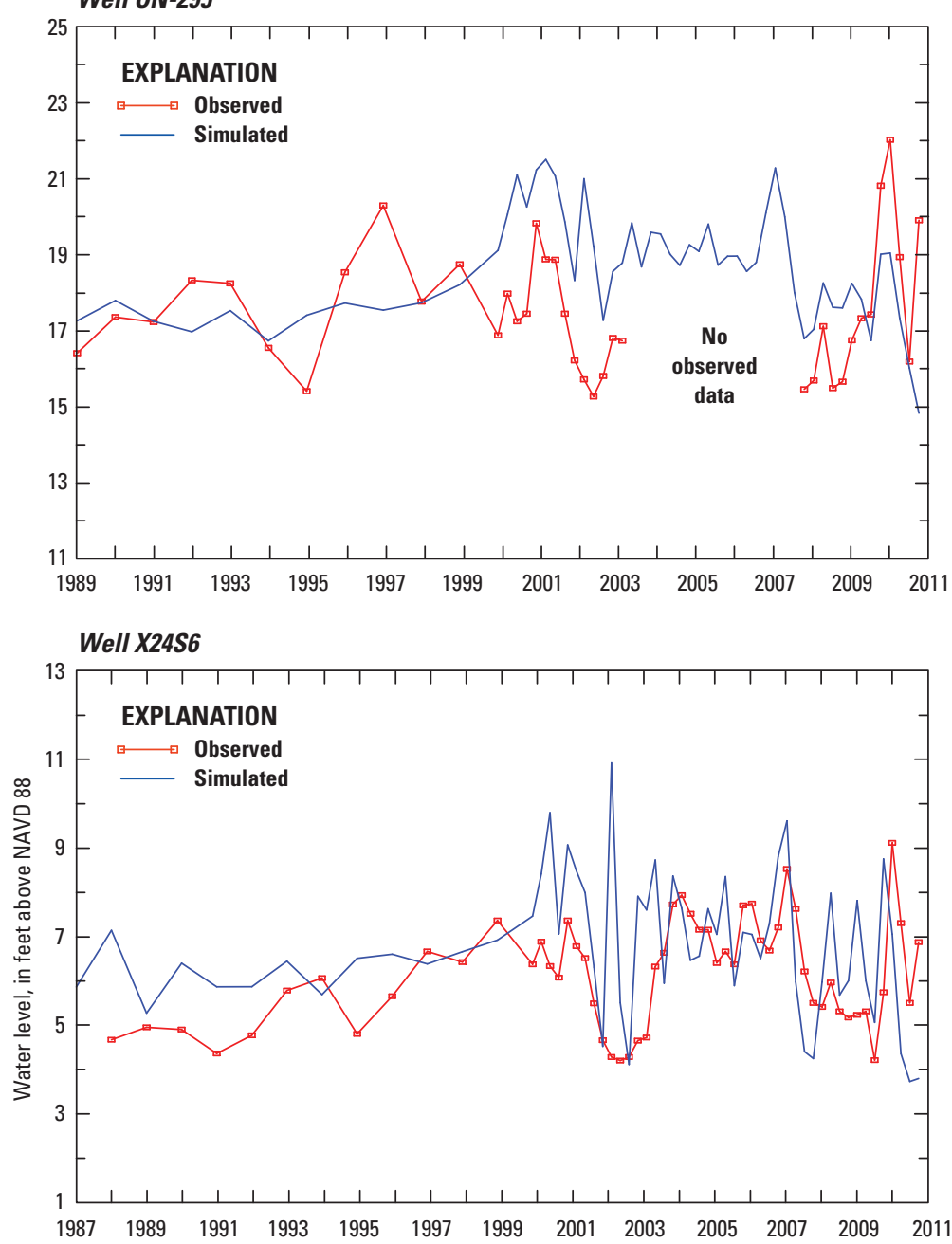

Well Y2503

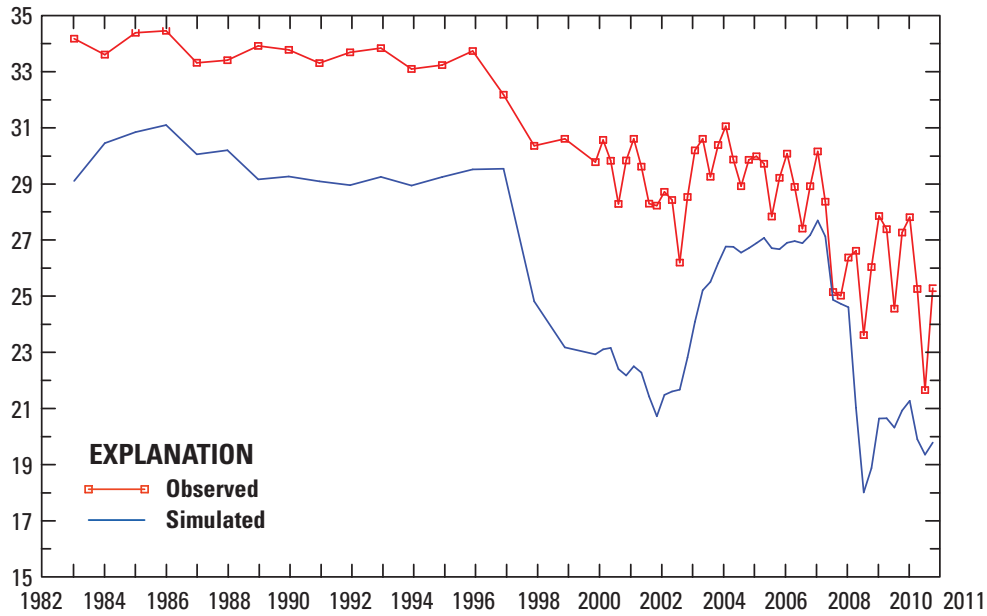

Figure 24. Hydrographs showing simulated and observed water levels at selected wells in the upper Castle Hayne aquifer (model layer 3). 

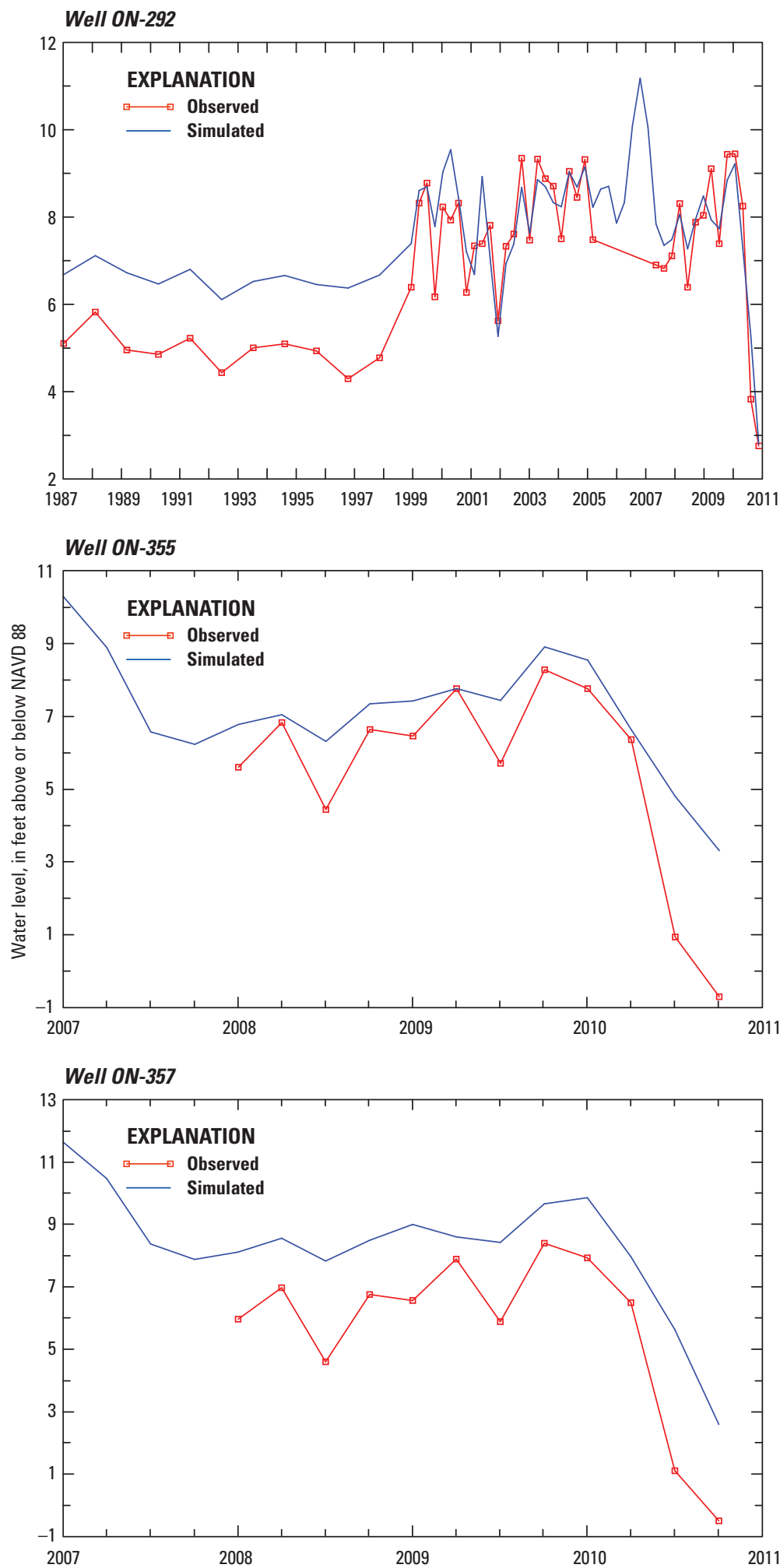

Figure 25. Hydrographs showing simulated and observed water levels at selected wells in the lower Castle Hayne aquifer (model layer 5). 


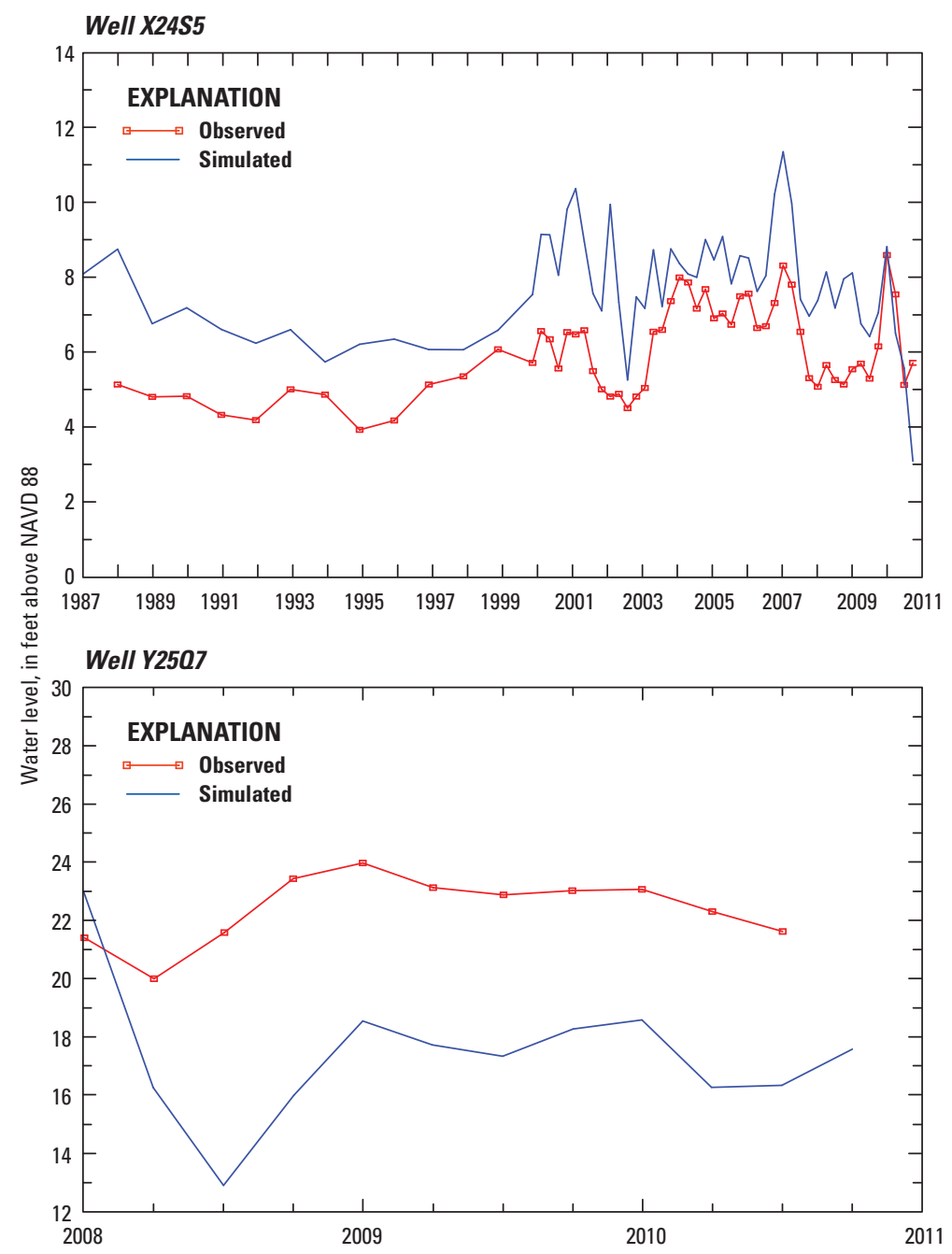

Figure 25. Hydrographs showing simulated and observed water levels at selected wells in the lower Castle Hayne aquifer (model layer 5).-Continued

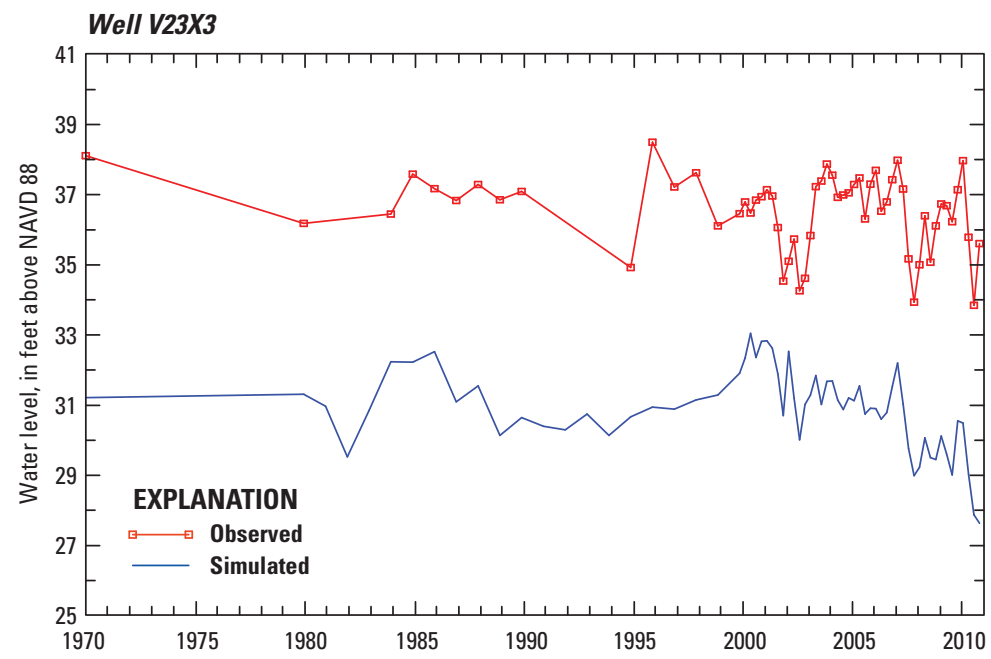

Figure 26. Hydrographs showing simulated and observed water levels at selected wells in the Beaufort aquifer (model layer 7). 


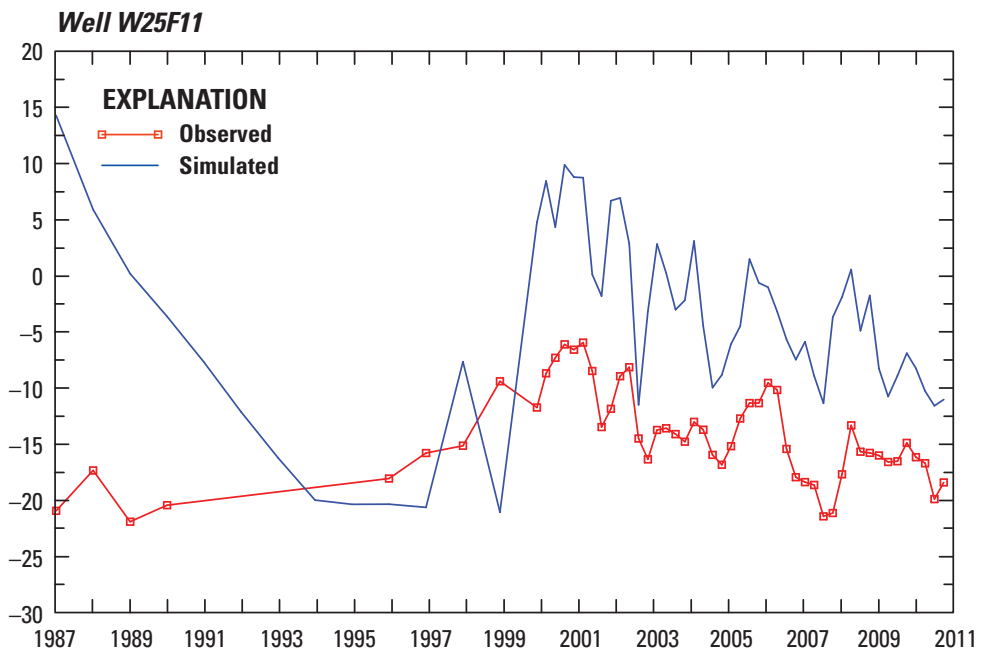

Well X24S4

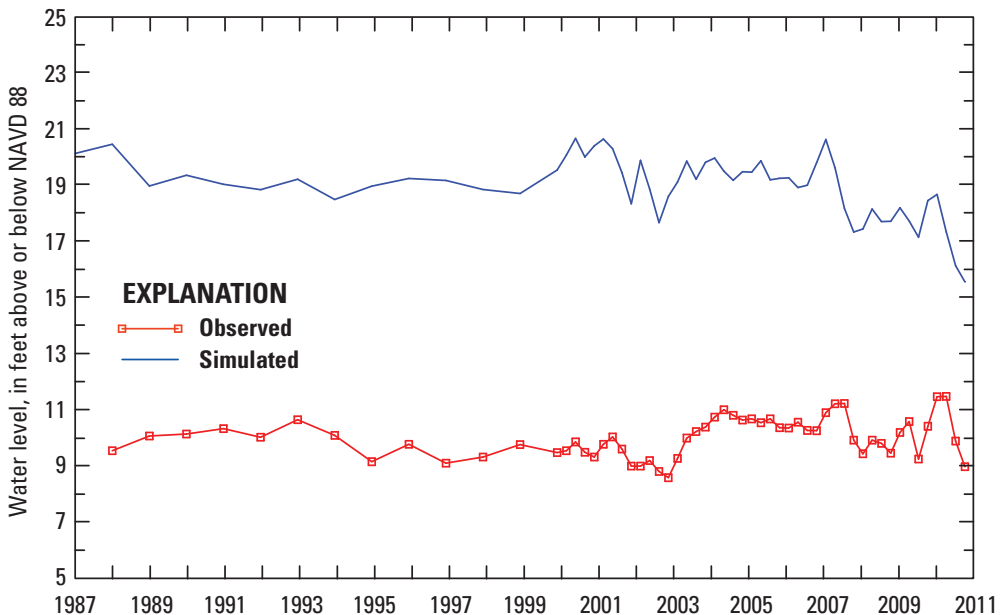

Well Y2504

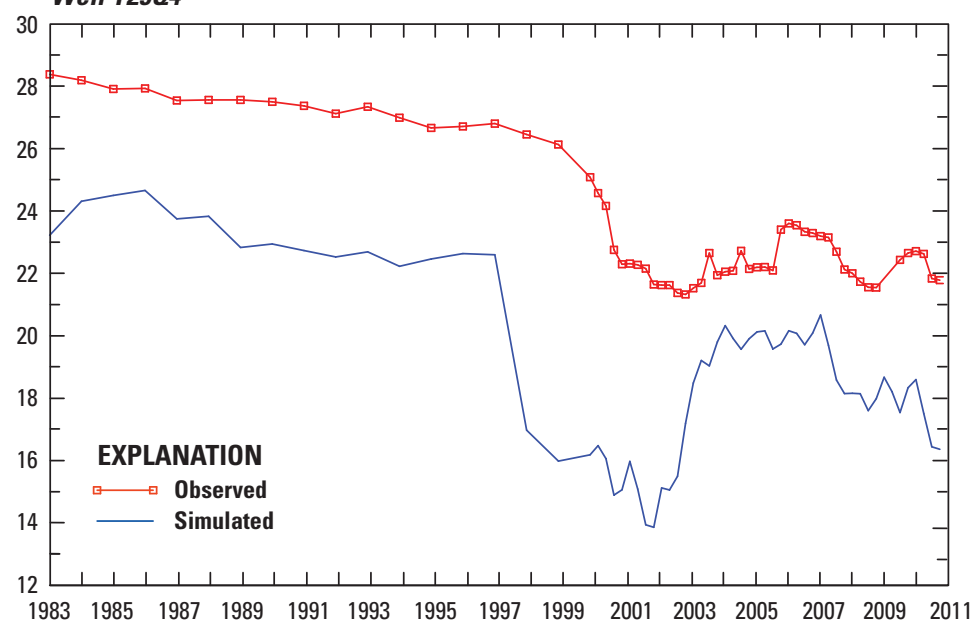

Figure 27. Hydrographs showing simulated and observed water levels at selected wells in the Peedee aquifer (model layer 9). 

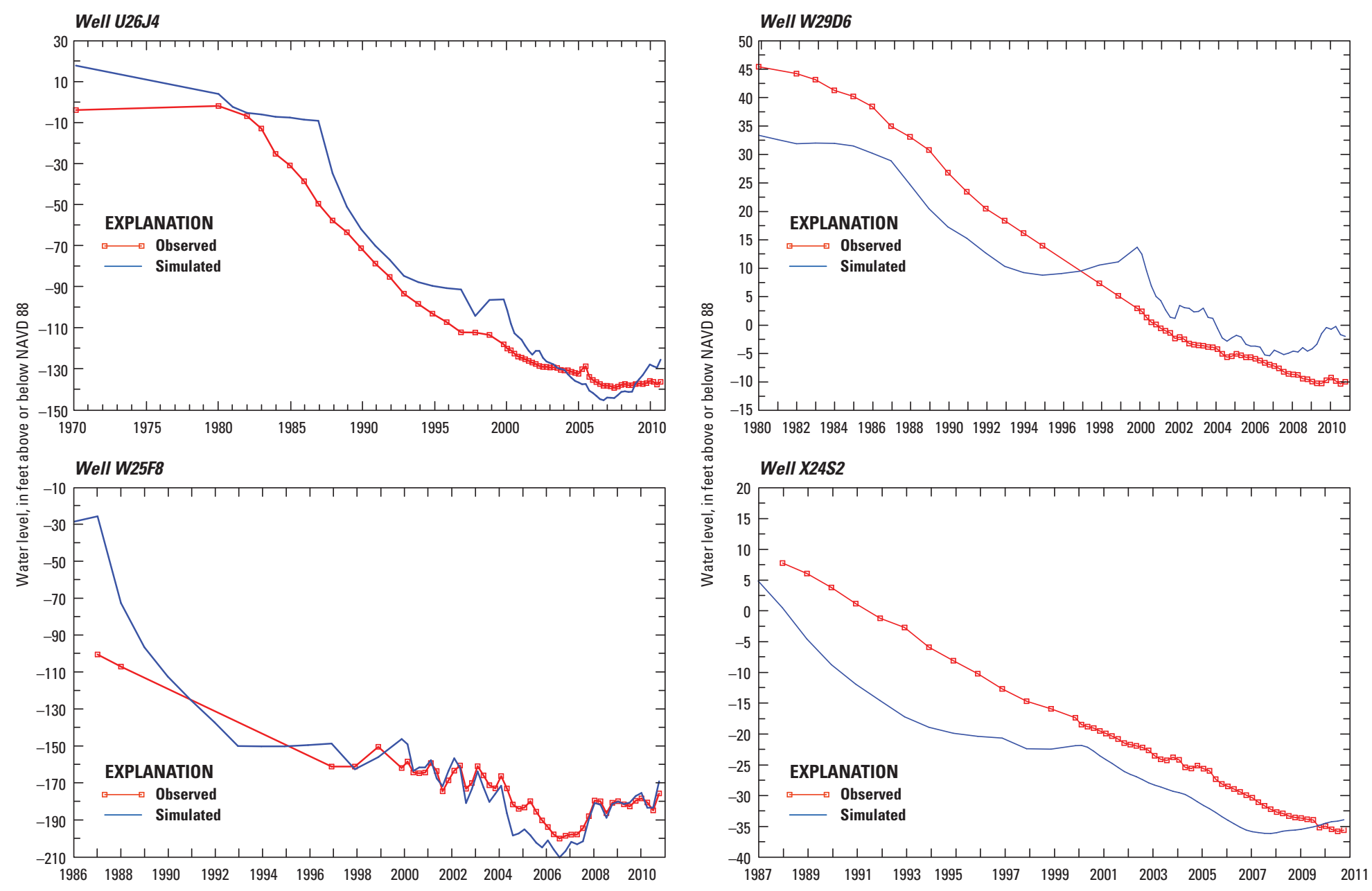

Figure 28. Hydrographs showing simulated and observed water levels at selected wells in the Black Creek aquifer (model layer 11).

\section{Model Fit-Stream Base Flow}

Calculated and simulated mean-annual base flows were compared at three USGS streamgages in the study area. Simulated base flows, derived from flux observations from the model, at Trent River near Trenton, North Carolina, and New River near Gum Branch, North Carolina, are within a factor of two of the observed base flow (estimated using hydrograph separation) and less than an order of magnitude smaller than the observed base flows at Northeast Cape Fear River near Chinquapin, North Carolina (table 5). For simulated base flows, 55 and 47 percent of the residuals at Trent River near Trenton, North Carolina, and New River near Gum Branch, North Carolina, respectively, were within the 50 percent error criterion, and 10 percent of the residuals at Northeast Cape Fear River near Chinquapin, North Carolina, were within the 50 percent error criterion. For the two smaller drainage area sites (Trent River and New River), simulated base flow is within the uncertainty of the observed value and considered a good fit. The largest underestimation of base flow is for the streamgage with the largest drainage area $\left(599 \mathrm{mi}^{2}\right)$; even though the ratio of base flow per unit area is similar for the three watersheds. The larger the drainage area, the greater the variation in rainfall over that area; this variation could have an effect on the model results. For this reason, Rutledge (2000) recommends that drainage areas should be greater than $1 \mathrm{mi}^{2}$, but less than $500 \mathrm{mi}^{2}$ when hydrograph separation is used as an estimate of groundwater discharge. Additionally, the Northeast Cape Fear River is in a flat, swampy terrain within the model area, which is not ideal for hydrograph separation. In flat, swampy terrain, slow surface-water drainage leads to overestimation of base flow. Thus, the poorer fit for the Northeast Cape Fear River, although not ideal, was deemed acceptable.

\section{Final Distribution of Hydraulic Properties}

The ranges and sample statistics for final calculated horizontal hydraulic conductivities $\left(\mathrm{K}_{\mathrm{h}}\right)$ for all model zones (aquifers and confining units) are given in table 10 . In the aquifers (zones 1, 3, 5, 7, 9, and 11), the $\mathrm{K}_{\mathrm{h}}$ ranged from $0.53 \mathrm{ft} / \mathrm{d}$ (zone 11, Black Creek aquifer) to $296 \mathrm{ft} / \mathrm{d}$ (zone 5, lower Castle Hayne aquifer); the highest mean value was in zone 7 (Beaufort aquifer; $70.8 \mathrm{ft} / \mathrm{d}$ ), and the lowest occurred in zone 9 (Peedee aquifer ; $4.41 \mathrm{ft} / \mathrm{d}$ ). In the confining units, $\mathrm{K}_{\mathrm{h}}$ ranged from $1 \times 10^{-5} \mathrm{ft} / \mathrm{d}$ to $4.83 \mathrm{ft} / \mathrm{d}$, both in zone 10 , the Black Creek 
confining unit. The vertical hydraulic conductivities were calculated using the calibrated $\mathrm{K}_{h}$ and the calibrated vertical anisotropy values (table 10). Vertical anisotropy values were calculated at each $\mathrm{K}_{\mathrm{h}}$ pilot point and well location and ranged from 2.99 to 5.91 .

Calibrated specific storage values ranged from $2.10 \times 10^{-7} \mathrm{ft}^{-1}$ to $8.37 \times 10^{-5} \mathrm{ft}^{-1}$ for the confined aquifers and confining units (excluding model layer 1 , zone 1 ). For model layer 1 (surficial aquifer), a specific storage of $9.00 \times 10^{-4} \mathrm{ft}^{-1}$ was calibrated. Specific storage multiplied by the thickness of the surficial aquifer produces specific yield, which had a mean value of $4.43 \times 10^{-2} \mathrm{ft}^{-1}$ (table 10 ).

The spatial distribution of hydraulic conductivity is determined within zones (using the aquifer and confining unit extents in model layers) based on Kriging interpolation between the pilot point values as determined from the parameter estimation process. The final value is based on the initial value of the pilot point and the range provided for each zone and point as described previously. The final spatial distribution of horizontal hydraulic conductivity for all model layers is shown in figures 29-39.

Model layer 1 represents the surficial aquifer over the entire simulated area (zone 1, fig. 10A; fig. 29). The calibrated horizontal hydraulic conductivity ranges from 5.06 to $199 \mathrm{ft} / \mathrm{d}$, typical for this type of aquifer (fig. 29; table 10).

Model layer 2 is predominantly the upper Castle Hayne confining unit (zone 2, fig. 10B) and the area was split into three parts (fig. 30). The upper part of the Coastal Plain area is part of the surficial aquifer (no effective confining unit) and in this area the calibrated horizontal hydraulic conductivity ranges from 5 to $10 \mathrm{ft} / \mathrm{d}$, moving coastward the area becomes confined and the hydraulic conductivity ranges from $1.0 \times 10^{-5}$ to $0.40 \mathrm{ft} / \mathrm{d}$, and within the ocean area the calibrated hydraulic conductivity is less than $1.0 \times 10^{-5} \mathrm{ft} / \mathrm{d}$ (fig. 30 ).

Model layer 3 represents the upper Castle Hayne aquifer near the coast, and in the upper part of the Coastal Plain the model layer is zoned as the surficial aquifer; part of the upper Castle Hayne confining unit is between the two aquifers (figs. $10 C$ and 31). The Castle Hayne is a carbonate aquifer, thus there can be a highly variable range in the calibrated hydraulic conductivity over shorter distances in this aquifer (2.22 to $233 \mathrm{ft} / \mathrm{d}$ ) (fig. 31; table 10).

Model layer 4 predominantly represents the lower Castle Hayne confining unit near the coast, the upper Castle Hayne confining unit to the west, and the surficial aquifer in the upper Coastal Plain (figs. $10 D$ and 32). Hydraulic conductivity of the lower Castle Hayne confining unit ranges from $2.10 \times 10^{-5}$ to $1.78 \mathrm{ft} / \mathrm{d}$ and has a mean of $2.28 \times 10^{-2} \mathrm{ft} / \mathrm{d}$ (fig. 32; table 10 ).
Model layer 5 represents the lower Castle Hayne aquifer in the south and the eastern part of the model area (figs. $10 \mathrm{E}$ and 33). To the north and the west, the up-dip part of model layer 5 represents the surficial aquifer and confining units. Thus, the calibrated hydraulic conductivity distribution is similar to that of layer 3 (fig. 31). Similar to the upper Castle Hayne aquifer, the lower Castle Hayne aquifer has great variability in hydraulic conductivity, with a range of 1 to $296 \mathrm{ft} / \mathrm{d}$ (fig. 33; table 10).

Model layer 6 represents the Beaufort confining unit in the northeastern part of the model area and the Black Creek and Peedee confining units to the west, where the Beaufort units pinch out (fig. $10 F$ and 34). Additionally, in the upper Coastal Plain, layer 6 represents the surficial aquifer near the Fall Line (fig. 34). The calibrated horizontal hydraulic conductivity of the Beaufort confining unit ranges from $2.50 \times 10^{-5}$ to $7.70 \times 10^{-2} \mathrm{ft} / \mathrm{d}$ and has a mean of $6.50 \times 10^{-3} \mathrm{ft} / \mathrm{d}$ (fig. 34; table 10 ).

Model layer 7 represents the Beaufort aquifer in the northeastern part of the model area, the Black Creek and Peedee confining units where the Beaufort units pinch out, and the surficial aquifer in the upper Coastal Plain (figs. $10 G$ and 35). Because aquifer test data were not available for the Beaufort aquifer in the study area, the aquifer was calibrated using a single pilot point, which resulted in the aquifer being calibrated as a single zone. The calibrated horizontal hydraulic conductivity of the Beaufort aquifer ranges from 50 to $72 \mathrm{ft} / \mathrm{d}$ (fig. 35; table 10).

Model layer 8 represents the Peedee confining unit in the lower Coastal Plain and the surficial aquifer in the upper Coastal Plain (figs. $10 \mathrm{H}$ and 36). The calibrated horizontal hydraulic conductivity of the Peedee confining unit of this layer ranges from $2.30 \times 10^{-5}$ to $0.16 \mathrm{ft} / \mathrm{d}$ (fig. 36; table 10).

Model layer 9 represents the Peedee aquifer in the lower Coastal Plain, and the Black Creek confining unit and the surficial aquifer in the upper Coastal Plain (figs. 10I and 37). The Peedee aquifer has the lowest mean calibrated horizontal hydraulic of $4.41 \mathrm{ft} / \mathrm{d}$, with a range of 3.37 to $6.91 \mathrm{ft} / \mathrm{d}$ (table 10).

Model layer 10 represents the Black Creek confining unit in the lower Coastal Plain and the surficial aquifer in the upper Coastal Plain near the Fall Line (figs. $10 J$ and 38). The calibrated horizontal hydraulic conductivity of this confining unit ranges from $1.00 \times 10^{-5}$ to $4.83 \mathrm{ft} / \mathrm{d}$ (table 10 ).

Model layer 11 represents the Black Creek aquifer over the most of the model area (figs. $10 \mathrm{~K}$ and 39). The final calibrated range in horizontal hydraulic conductivity for the aquifer is approximately 0.53 to $50 \mathrm{ft} / \mathrm{d}$ with a mean of $10.6 \mathrm{ft} / \mathrm{d}$ (table 10). 


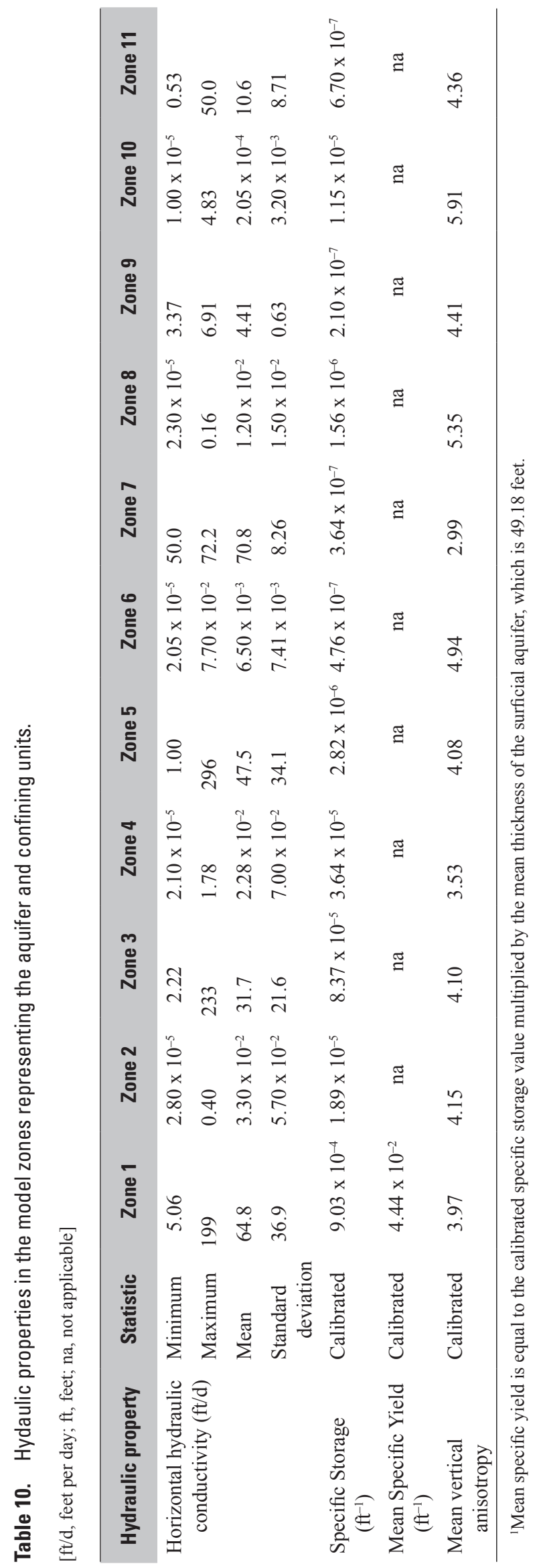




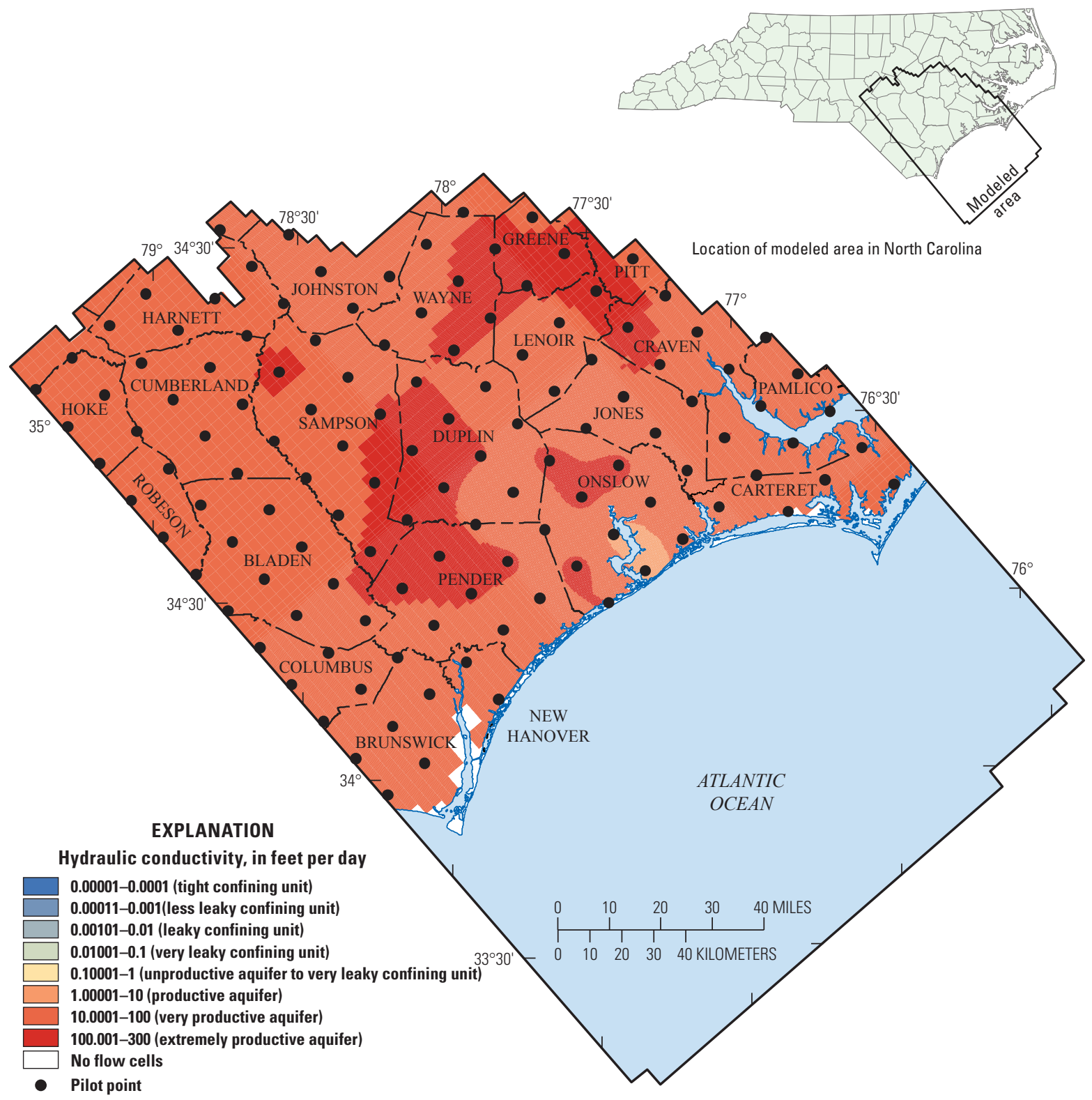

Figure 29. Map of the final distribution of horizontal hydraulic conductivity and location of pilot points and wells of the surficial aquifer, model layer 1. 


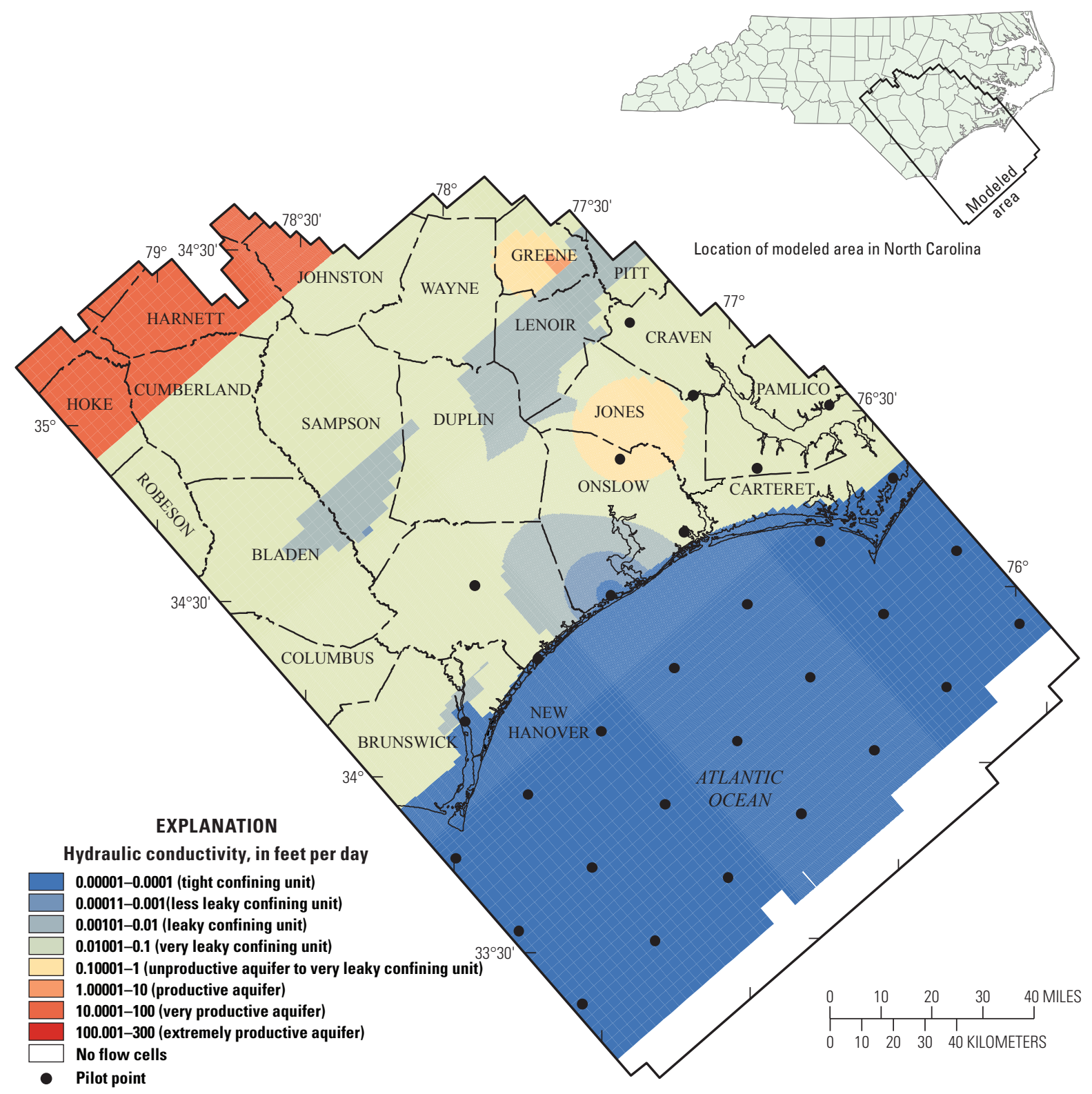

Figure 30. Map of the final distribution of horizontal hydraulic conductivity and location of pilot points of the upper Castle Hayne confining unit, model layer 2. 


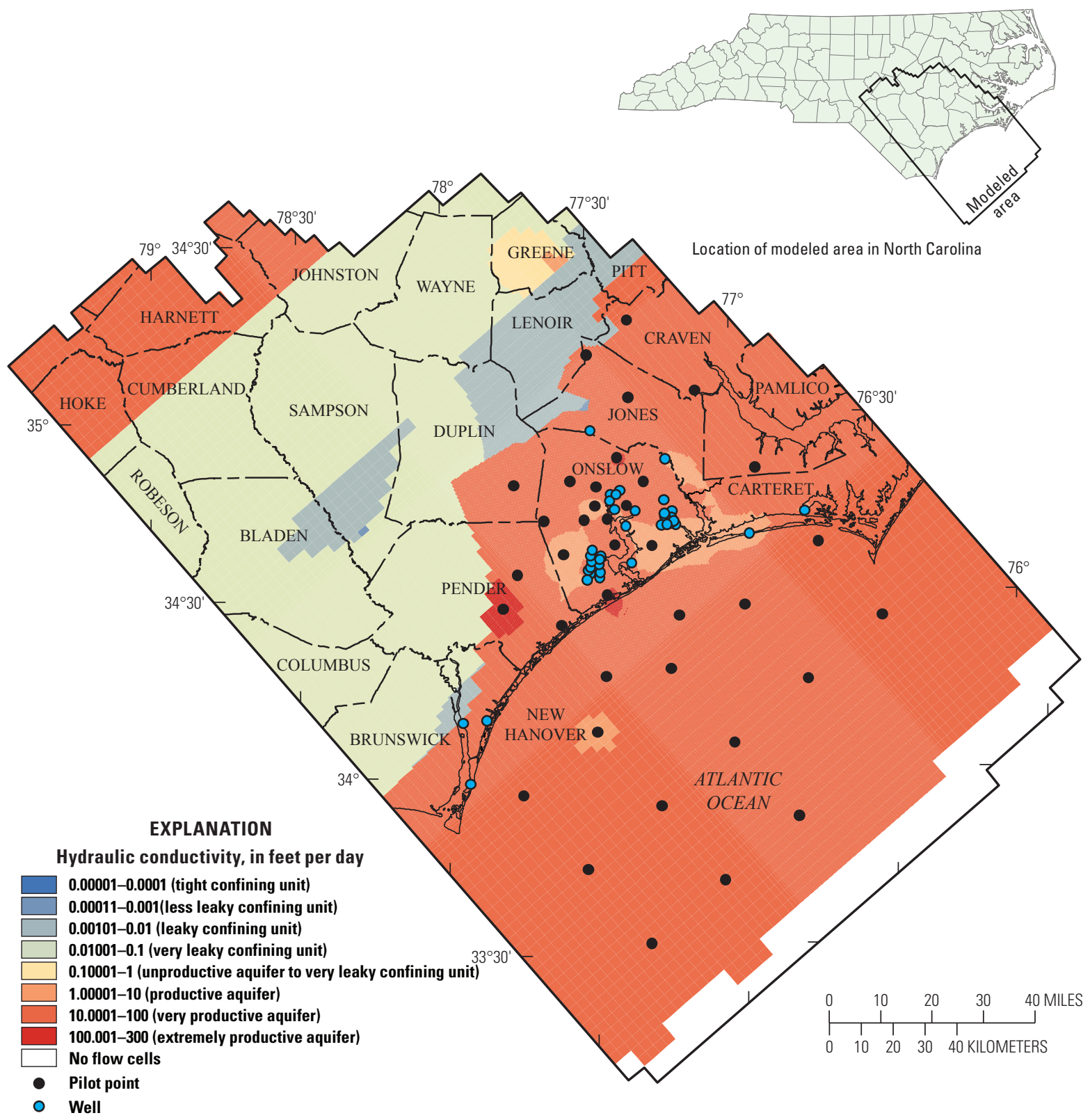

Figure 31. Map of the final distribution of horizontal hydraulic conductivity and location of pilot points and wells of the upper Castle Hayne aquifer, model layer 3. 


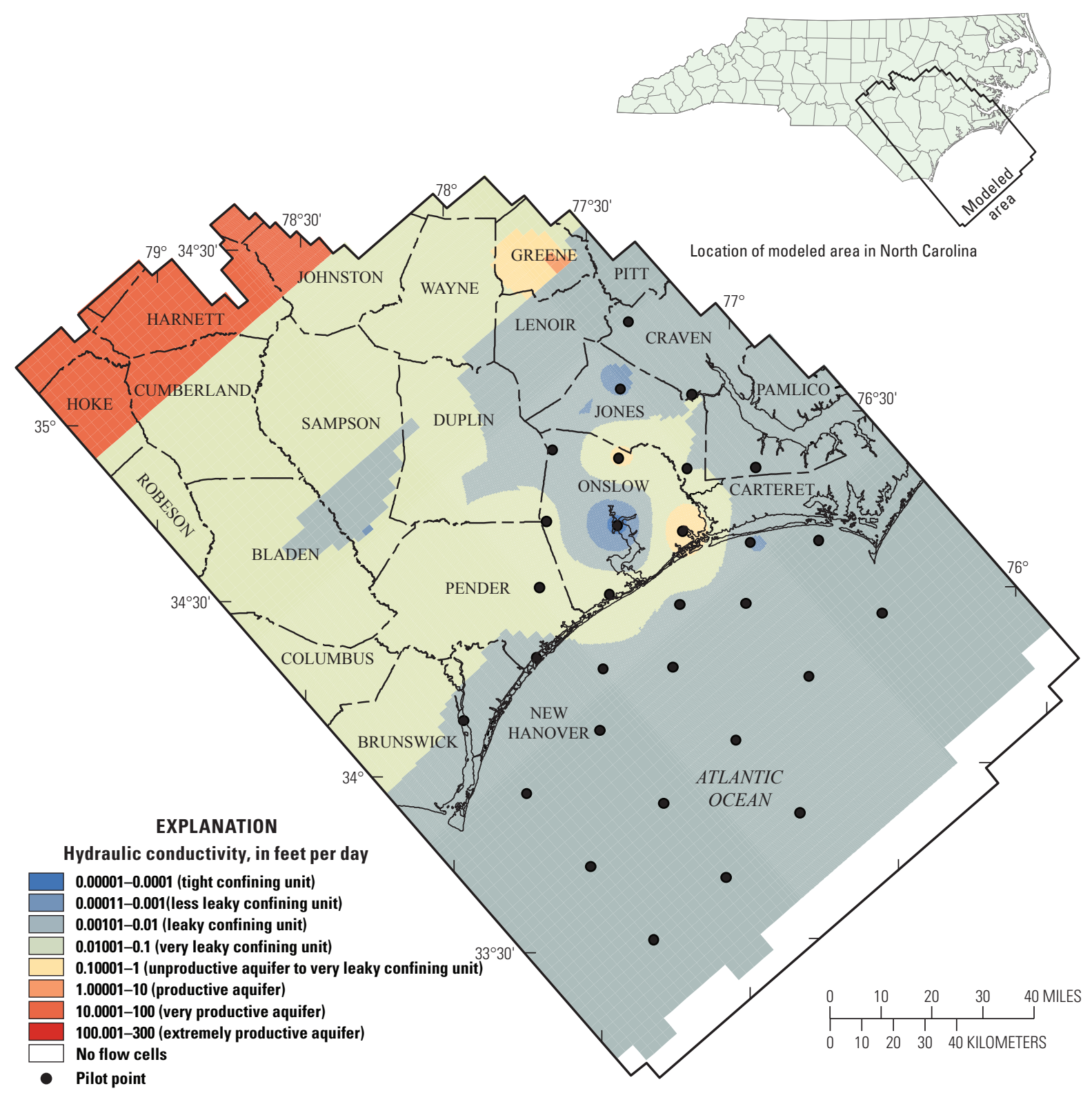

Figure 32. Map of the final distribution of horizontal hydraulic conductivity and location of pilot points of the lower Castle Hayne confining unit, model layer 4. 


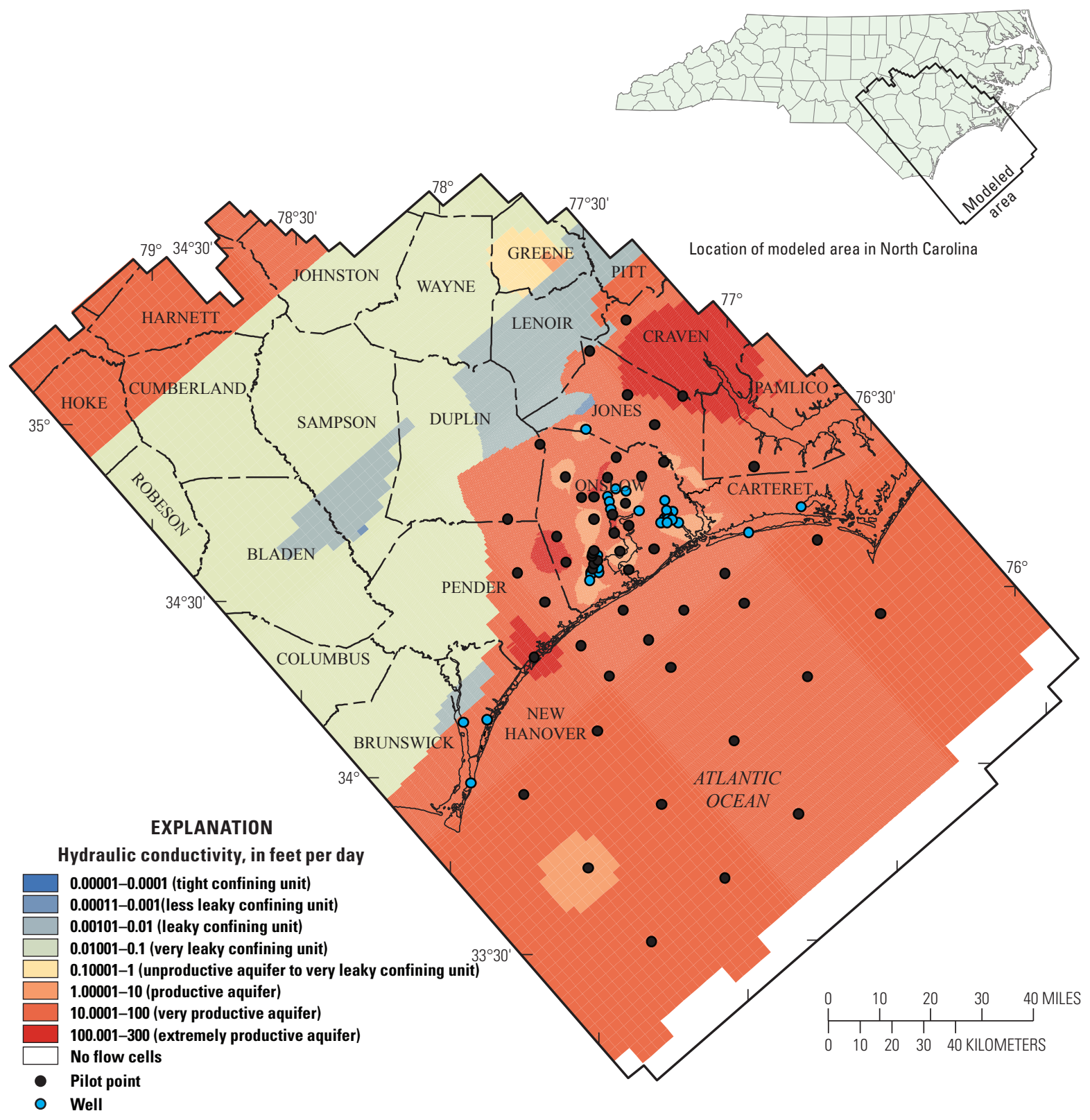

Figure 33. Map of the final distribution of hydraulic conductivity and location of pilot points and wells of the lower Castle Hayne aquifer, model layer 5. 


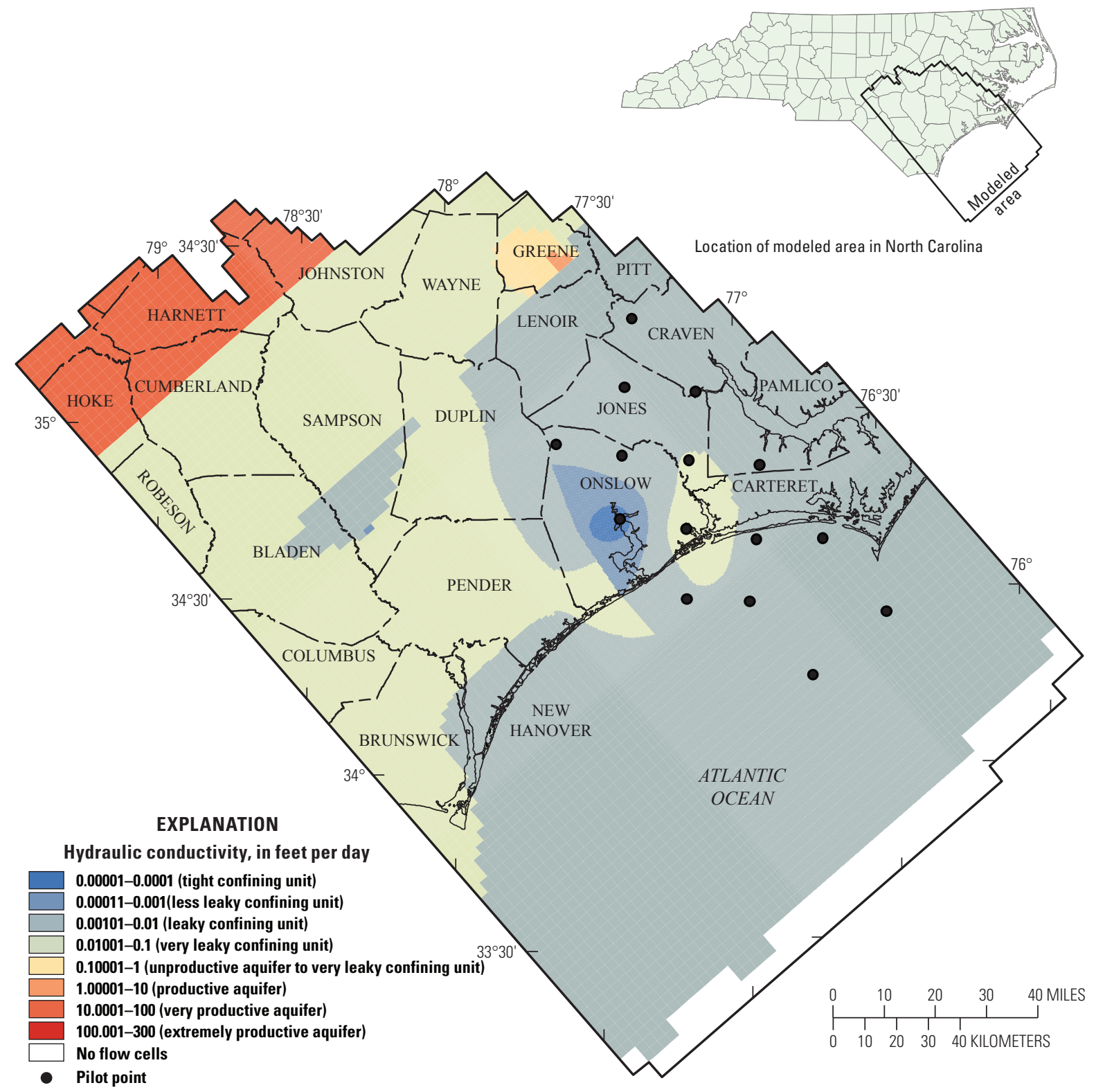

Figure 34. Map of the final distribution of horizontal hydraulic conductivity and location of pilot points of the Beaufort confining unit, model layer 6. 


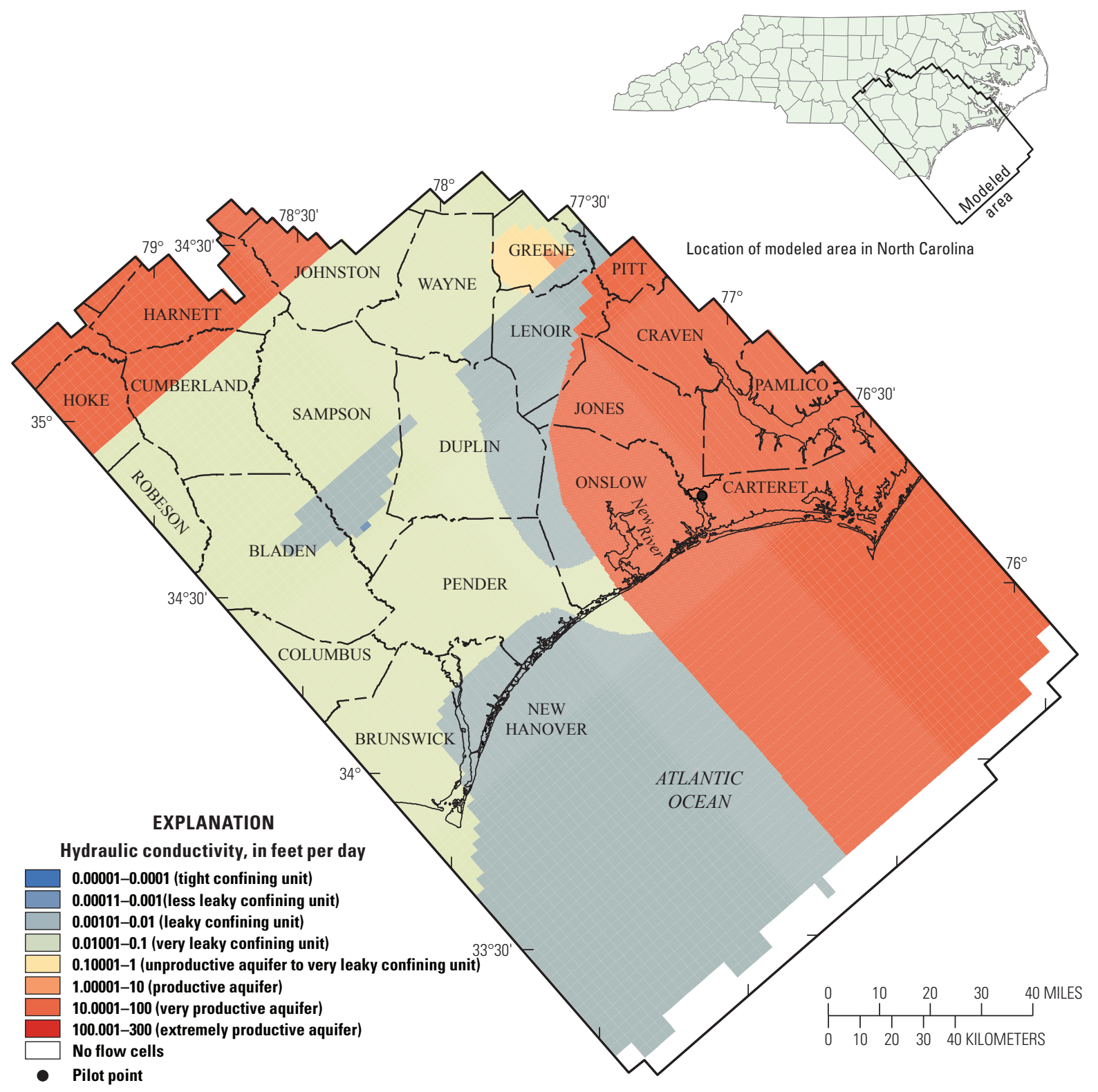

Figure 35. Map of the final distribution of horizontal hydraulic conductivity and location of pilot points and wells of the Beaufort aquifer, model layer 7. 


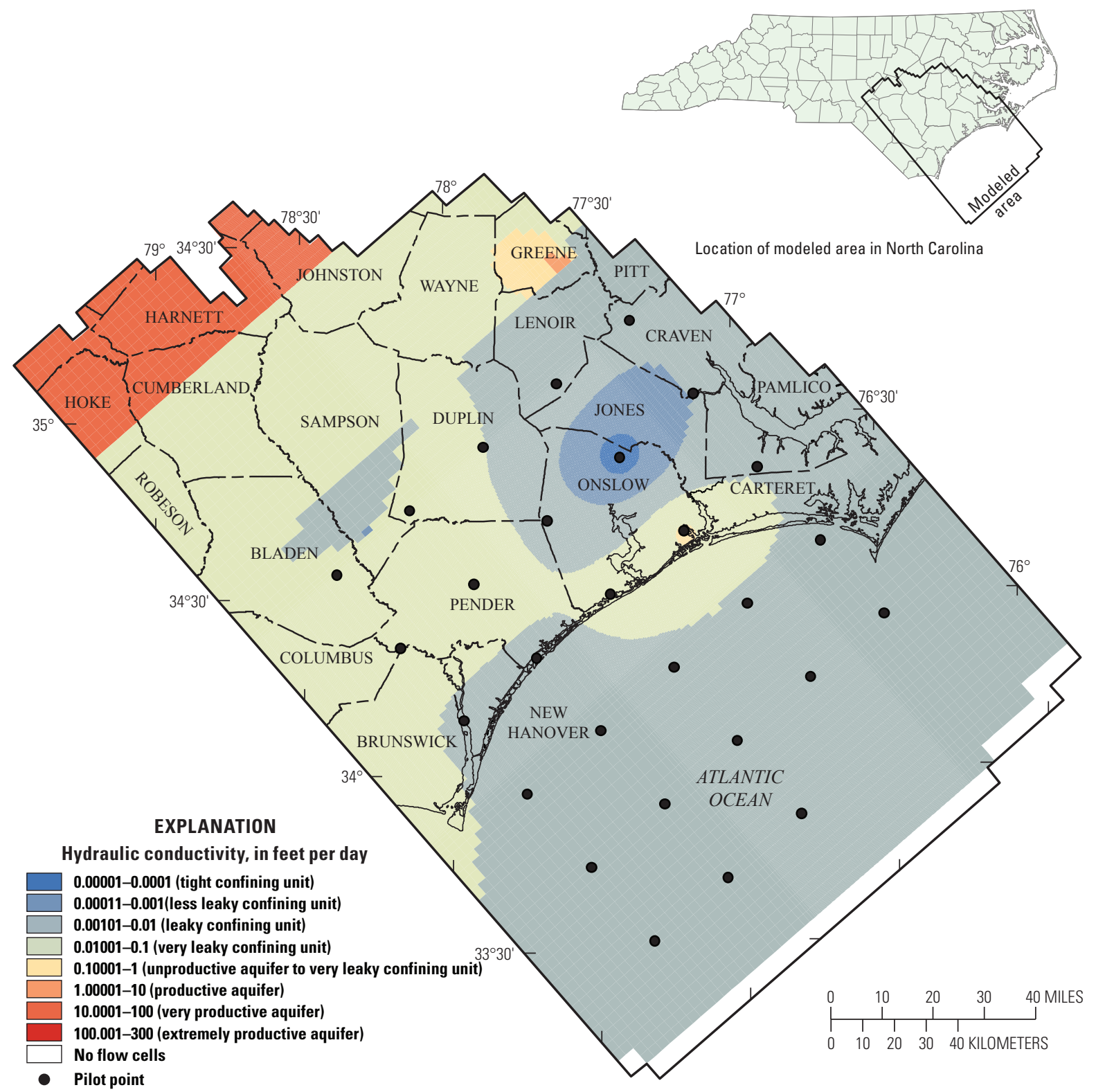

Figure 36. Map of the final distribution of horizontal hydraulic conductivity and location of pilot points of the Peedee confining unit, model layer 8. 


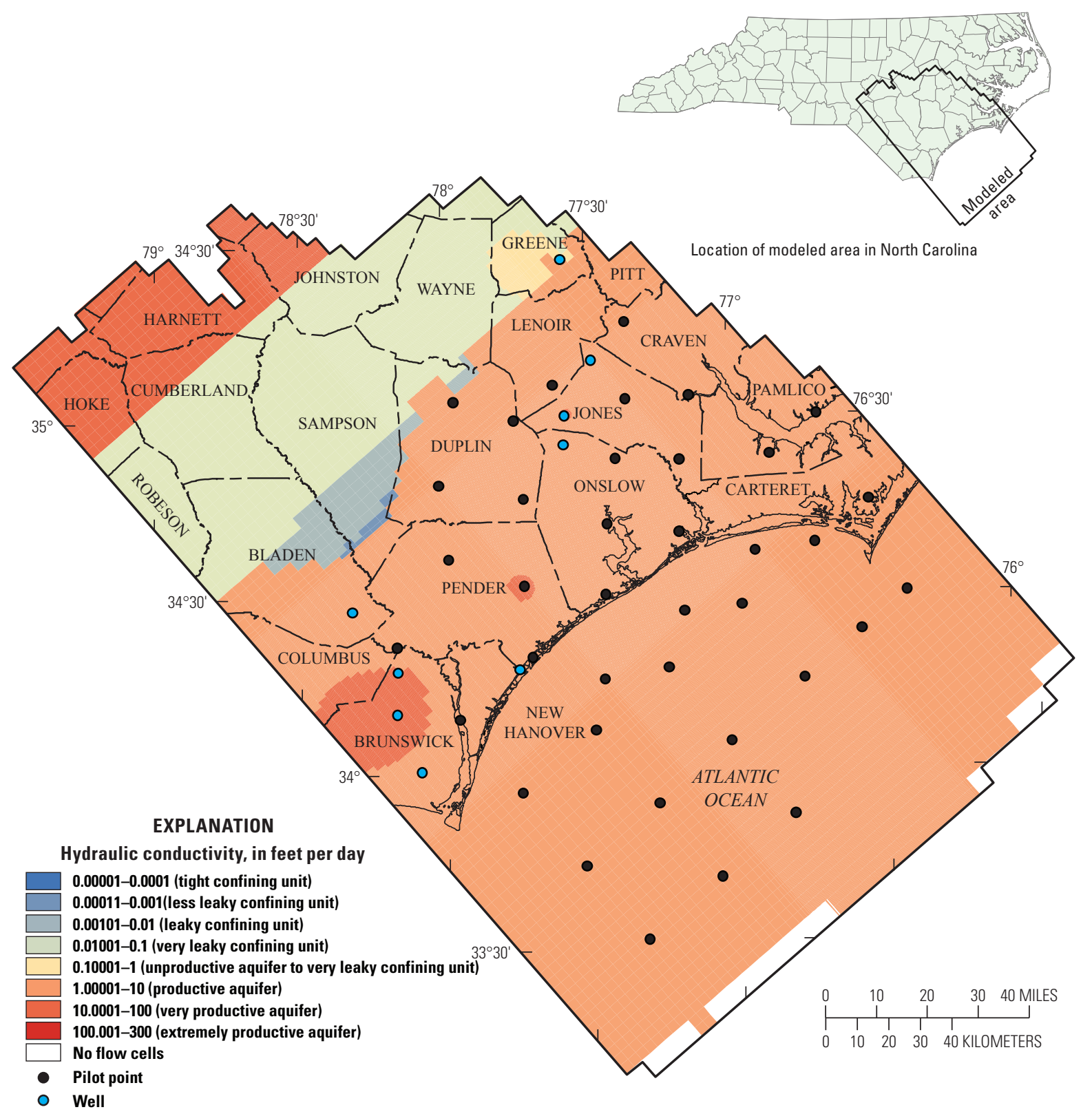

Figure 37. Map of the final distribution of horizontal hydraulic conductivity and location of pilot points and wells of the Peedee aquifer, model layer 9. 


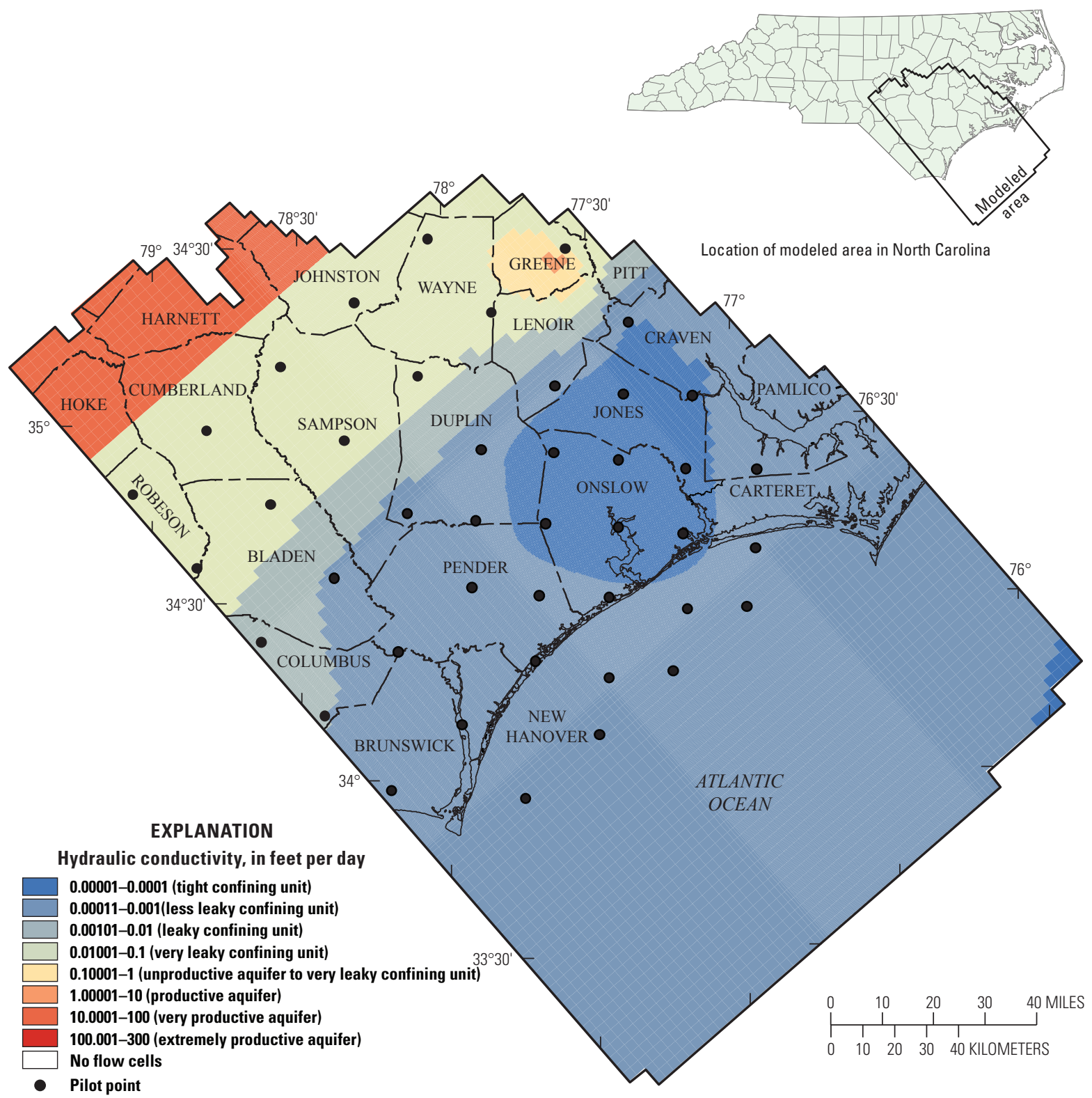

Figure 38. Map of the final distribution of horizontal hydraulic conductivity and location of pilot points of the Black Creek confining unit, model layer 10. 


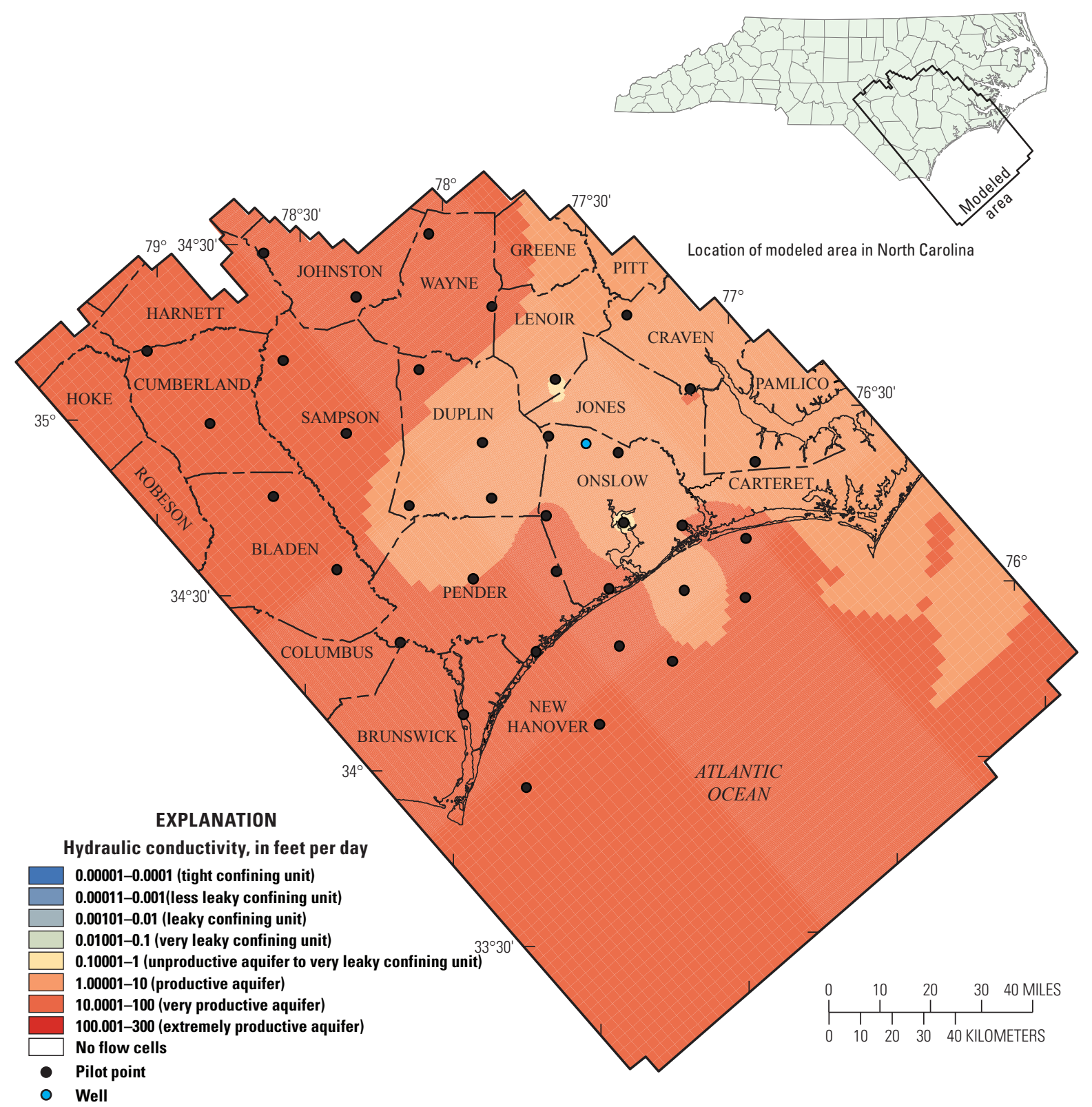

Figure 39. Map of the final distribution of horizontal hydraulic conductivity and location of pilot points and wells of the Black Creek aquifer, model layer 11. 


\section{Final Net Groundwater Recharge}

Calculated net groundwater recharge was adjusted during calibration using a recharge multiplier for each stress period. The initial value of each recharge multiplier was 1 and was allowed to vary between 0.5 and 3 . The average multiplier was 1.09; the median multiplier was 0.93 with five values at the upper bound and 13 values at the lower bound. The majority of the multipliers ( 60 percent) ranged from 0.53 to 1.36 . The calibration of the recharge multipliers produced a final range of net groundwater recharge of 0 to $0.00381 \mathrm{ft} / \mathrm{d}$ and a mean of $0.0009405 \mathrm{ft} / \mathrm{d}$ (table 11). This mean value equals 4.1 inches per year (in/yr) and is within the previously estimated long-term average range of net recharge ( 3 to $5 \mathrm{in} / \mathrm{yr}$ ) derived from surface-water data and climate budgets (table 1).

\section{Model Sensitivity}

The sensitivity of the calibrated model was evaluated using the composite sensitivity values generated by the PEST code. The composite sensitivity values indicate how accurately a model parameter can be estimated and also the relative importance of the model parameter on simulated groundwater levels and flows. Composite sensitivity is a dimensionless measure of the change in the calculated head with respect to the value of the parameter and is independent of the actual values of the observations (Hill, 1998). For a given model parameter, a larger composite sensitivity indicates more sensitivity of simulated conditions to the given parameter. Additionally, greater sensitivity increases the likelihood that changes in those parameters can affect simulated water levels.
Composite sensitivities were calculated for 1,022 parameters used in the model calibration (fig. 40). The parameters include 520 horizontal hydraulic conductivity values and 418 vertical anisotropy values associated with wells and pilot points within a hydrogeologic zone (fig. 10), 72 recharge multiplier values (one for each stress period), and 11 specific storage values (one for each zone) (fig. 40). The model is most sensitive to some of the pilot points for the hydraulic conductivity in zones 1,4 , and 5 , and vertical anisotropy pilot points in zone 4. Recharge multipliers had an overall smaller maximum sensitivity, with the largest value of 0.246 for stress period 27. Recharge multiplier sensitivity was greater than 0.15 for stress periods 27, 25, 23, 53, 26, 20, 28, 24, 22 (mostly the annual stress periods from 1991 to 1999 with one quarterly stress period during 2006; table 3). Recharge multiplier sensitivity is greater than 0.025 for 54 of the 72 stress periods. Thus, while no one recharge multiplier is as large as some of the other pilot point values for hydraulic properties, the overall sensitivity of the recharge multiplier is large. Relative composite sensitivities greater than 0.025 for the hydraulic conductivity and vertical anisotropy pilot points within the study area are shown in figure 41. Observations inside the study area are weighted higher than those outside of the study area during the calibration process; therefore, it is expected that the pilot points in the detailed grid area would have a higher impact during calibration than those pilot points outside of the study area. The model is relatively insensitive to the parameters for specific storage except in layer 1 (specific yield, unconfined aquifer). 


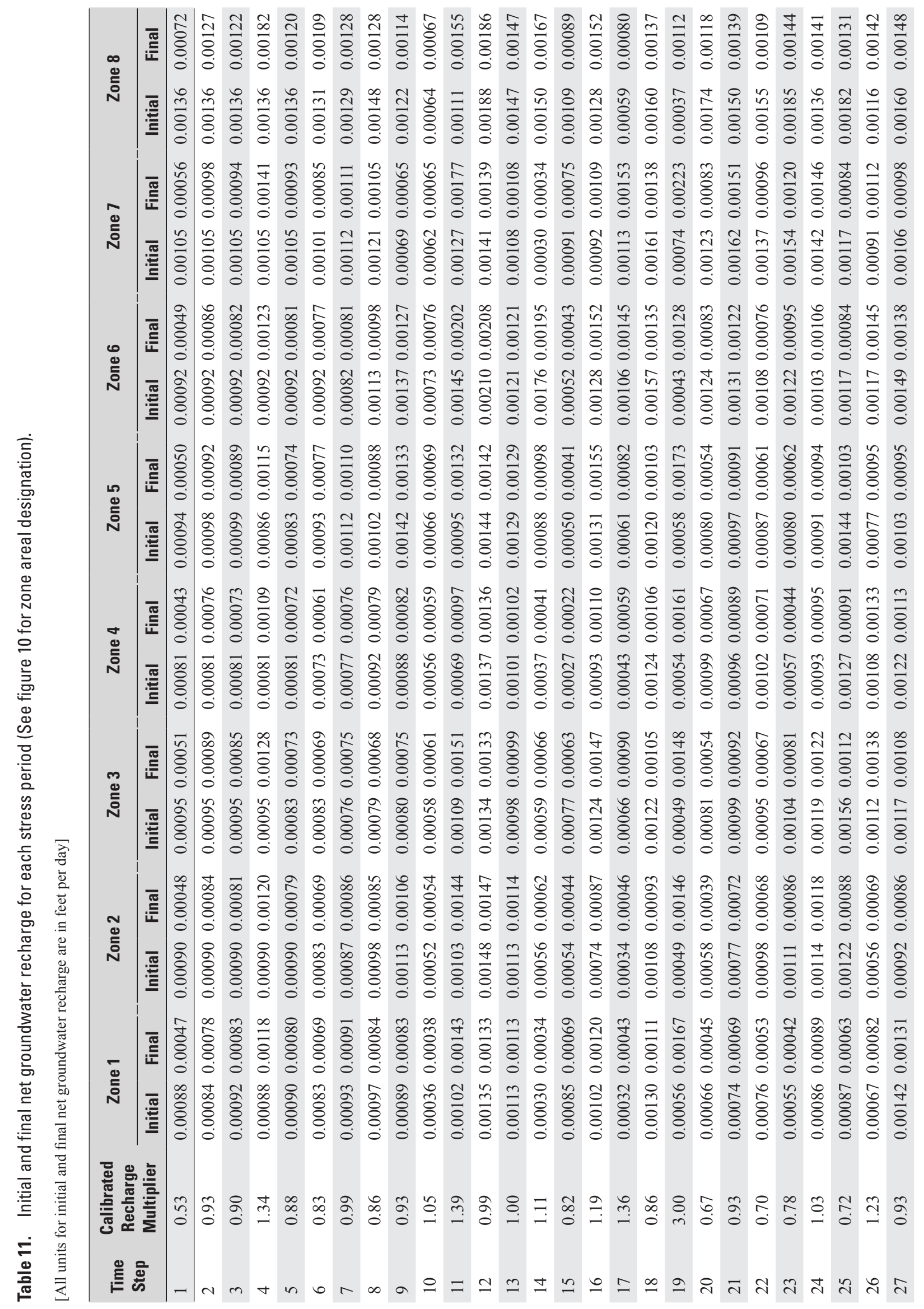


응 إ.

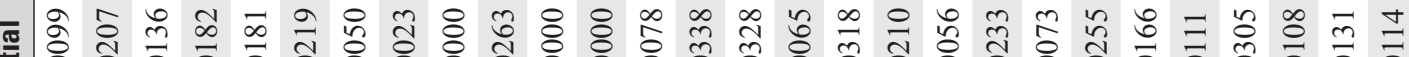

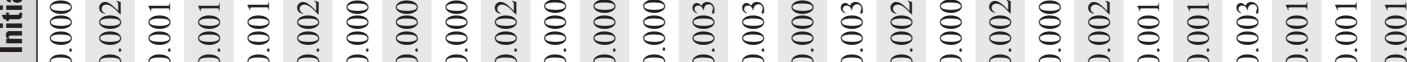

สิ

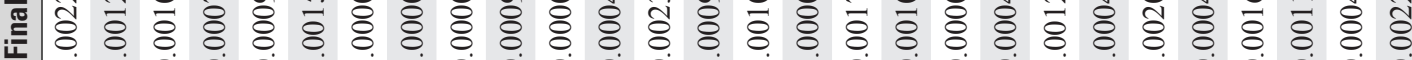

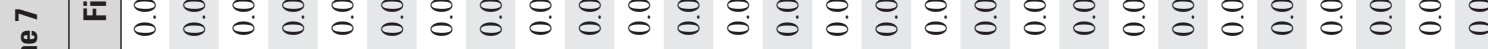

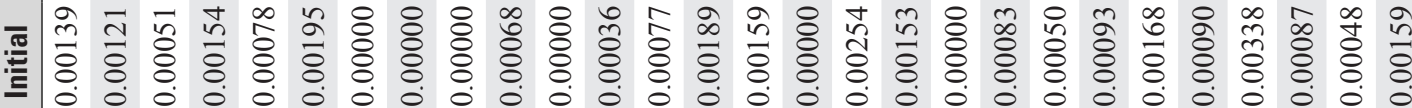

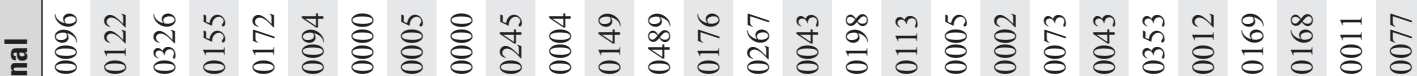


흔

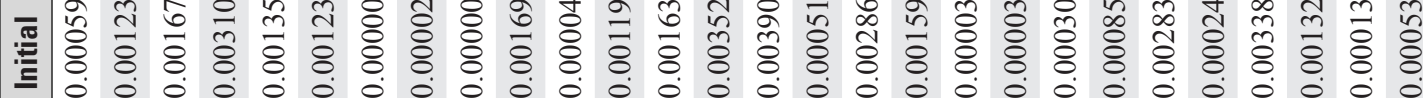

宩

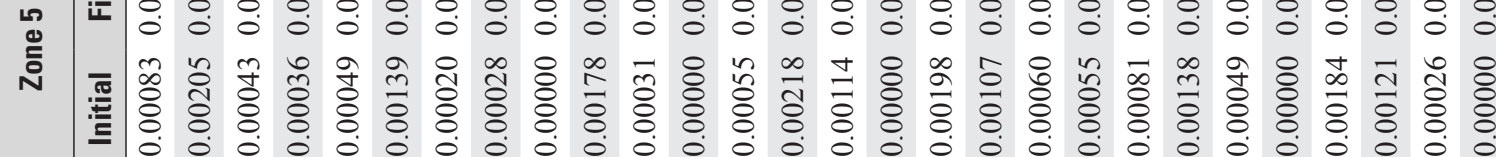

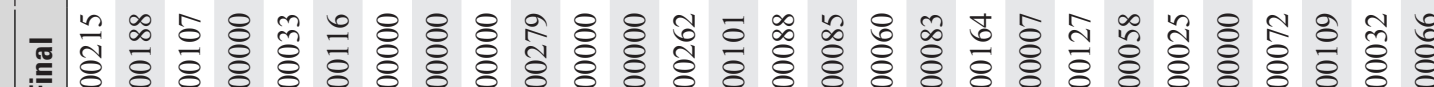
म నั้

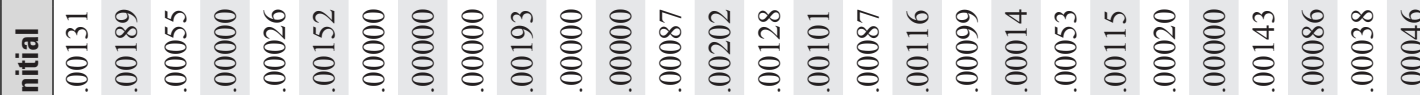

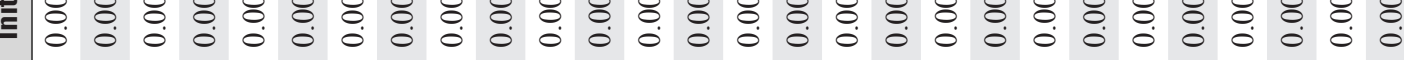
๘

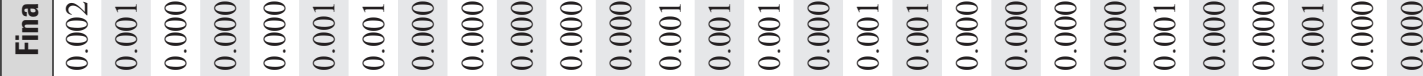

$\stackrel{m}{\square}$

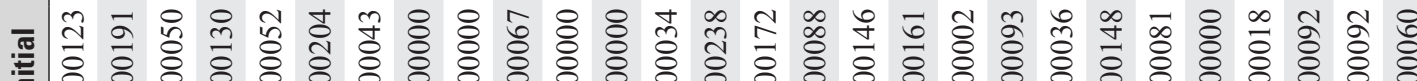

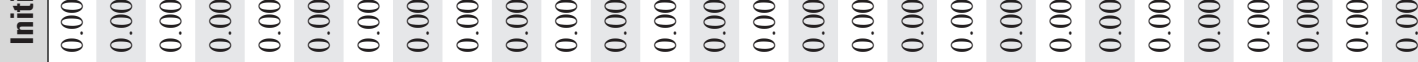

ఇ N ำ

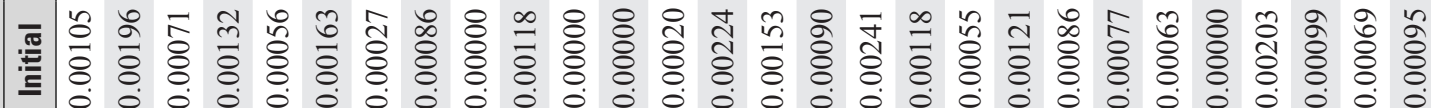

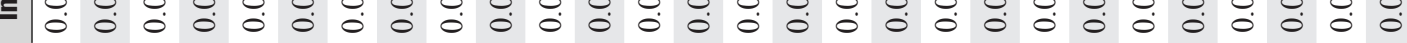
范 लॉ 


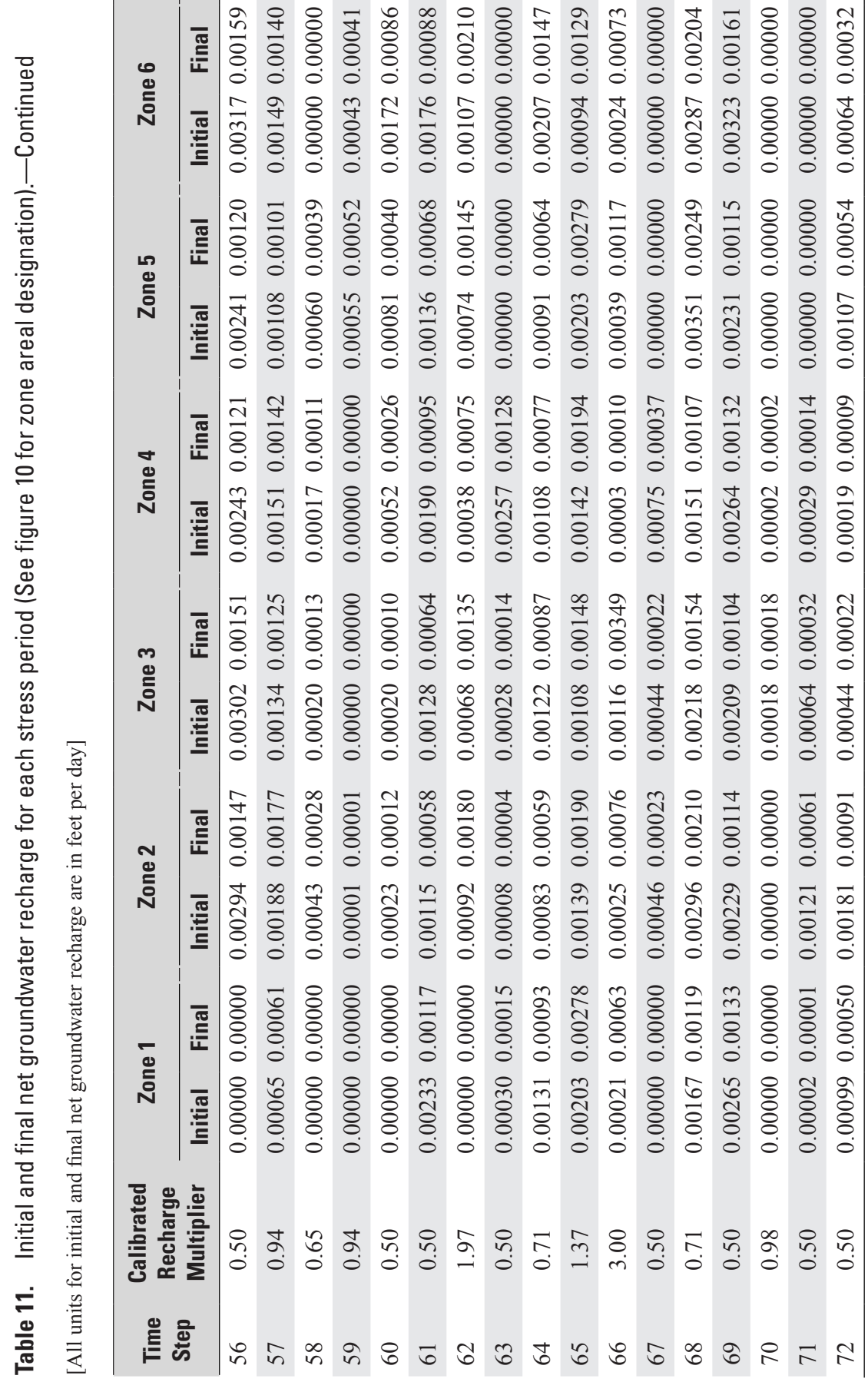




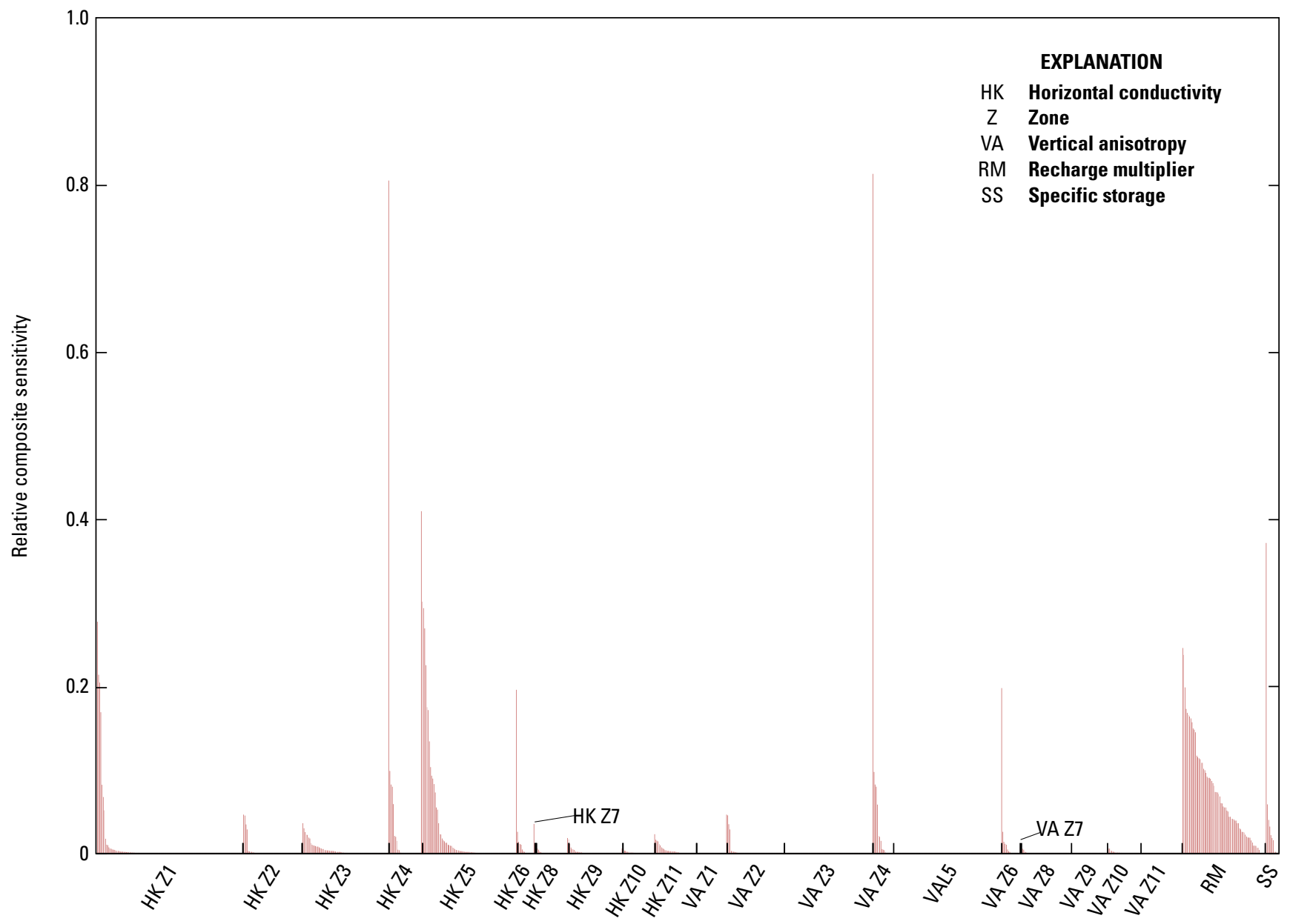

Figure 40. Relative composite sensitivities for the aquifer parameters and aquifer parameter pilot points. 

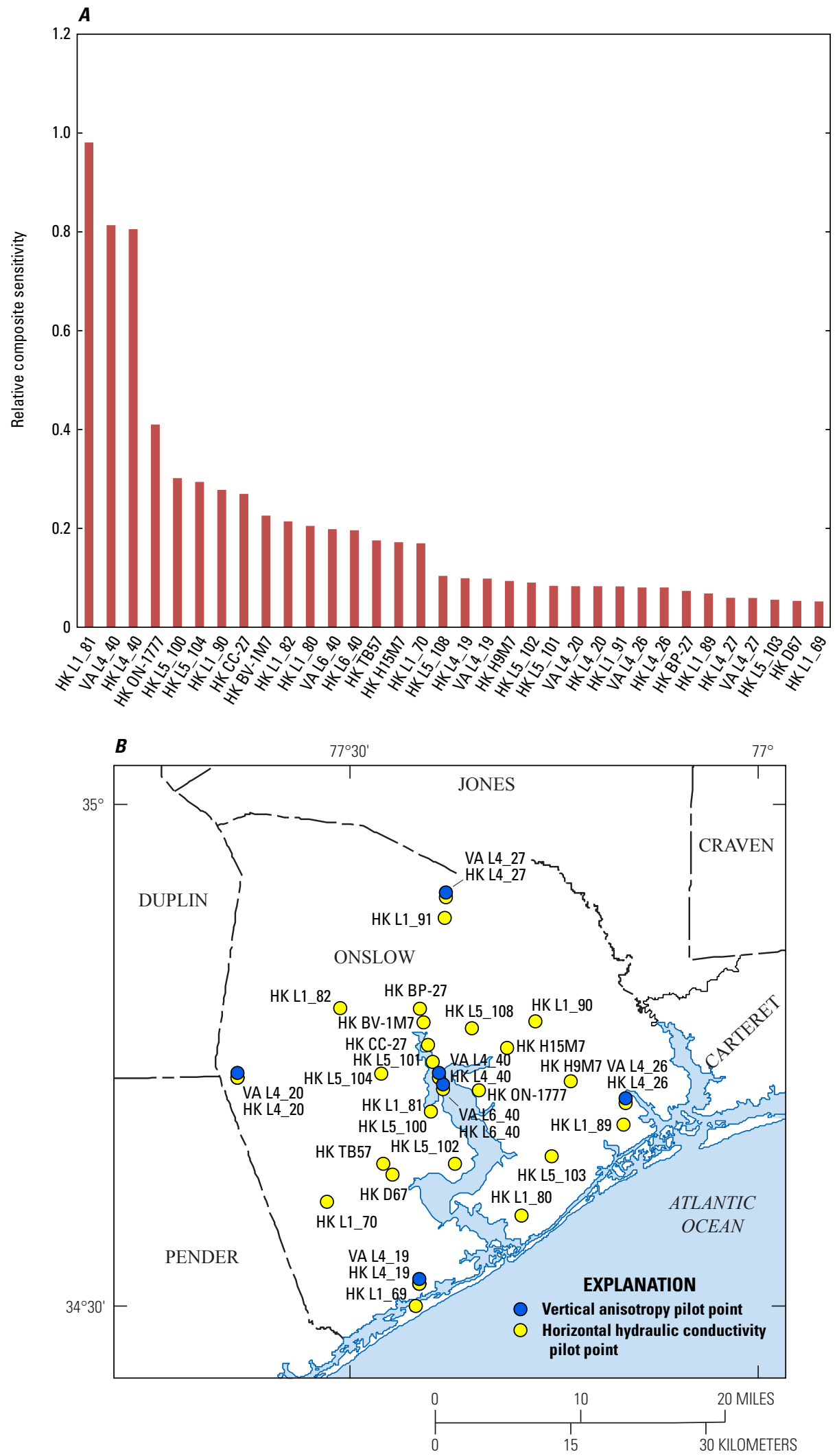

Figure 41. Graph of and locations for pilot points with relative composite sensitivities values greater than 0.025 . 


\section{Simulated Water Budget}

Simulated water budget components for the model include inflows from recharge, inflows and outflows from constant head boundaries, inflows and outflows from general head boundaries, inflows and outflows from storage, outflows to drains, and outflows to wells (fig. 42). Water budgets for the predevelopment and 2010 fourth quarter simulations are summarized by layer in tables 12 and 13, respectively.

For the predevelopment steady-state simulation (1900-09) the total inflow was 1,095 million gallons per day (Mgal/d) of which 94.3 percent was recharge and 5.7 percent was inflow from constant head boundaries (table 12). The total outflow, which was $1,095 \mathrm{Mgal} / \mathrm{d}$, comprises 91.4 percent discharge to drains, 4.1 percent outflow to general head boundaries, and 4.4 percent outflow to constant head boundaries.

The 2010 fourth quarter was near the end of several dry years (2008-10 were drier than average). Simulated total inflow was $1,221 \mathrm{Mgal} / \mathrm{d}$ of which 40.1 percent was inflows from storage, 55.2 percent was from recharge, and 4.7 percent was inflow from constant head boundaries (table 13). The total outflow, which was $1,221 \mathrm{Mgal} / \mathrm{d}$, comprises 76.9 percent discharge to drains, 6.3 percent outflow to constant head boundaries, 11.1 percent withdrawals to wells, 2.8 percent outflow to general head boundaries, and 2.9 percent back into storage. The change in storage results from raising or lowering of groundwater levels; as water levels drop, water moves out of storage into the aquifer (shown as inflow from storage in table 13) and as water levels rise, water moves from the aquifer into storage (outflow to storage).

The recharge (net groundwater inflow to the model) is generally a function of climate and is applied as a flux to the top model layer. The natural inflow is balanced by outflows to the streams and the coastal area boundary at predevelopment. The bar graph (fig. 42) shows how the water budget changes as some of the inflow that would naturally discharge to streams, swamps, and the coast is captured by wells (wells out, fig. 42). Rising and falling water levels induce changes in aquifer storage, and falling water levels reduce or eliminate discharge to drains and may induce leakage from swamps and wetlands.
The first eight stress periods represent average conditions over 10-year periods from 1900 through 1979 (table 3). Groundwater withdrawals generally were small and not reported until 1930 and remained relatively small until 1940. For this reason there is almost no change in storage in the water budget for the first five stress periods, and all changes are predominantly a result of change in climate (recharge in, fig. 42) over the 10-year stress periods (figs. 5 and 42). Groundwater withdrawals increased slightly between 1940 and 1980, and for these 10-year stress periods (5 through 8) there are also only small changes in storage and the overall water budget (figs. 5 and 42). Essentially, for these first eight stress periods, inflows and outflows are most similar to the predevelopment conditions with inflow from net groundwater recharge balanced by outflow to drains and general head boundaries that represent discharge to streams, swamps, and the coast.

From 1980 through 1999, annual stress periods (table 3) are used in the simulation (stress periods 9 through 28). Groundwater withdrawals increased during this period to about half of peak rate (fig. 5). While an annual stress period is much shorter than a 10-year stress period, it still represents average conditions and thus the variation in climate is a bit greater than the 10-year stress period and there are greater changes in storage as water levels rise and fall in response to variations in climate from year to year (fig. 42).

From 2000 through 2010, quarterly stress periods (table 3 ) are used in the simulation (stress periods 29 through 72). Large seasonal variations in net groundwater recharge result in large changes in rates from season to season (fig. 42). Additionally, groundwater withdrawals (wells out, fig. 42) increase during this period. While outflow to wells is a relatively small component of the water budget for the model area as compared to net groundwater recharge, the effect of the withdrawals is concentrated in the area of the cone of depression within the aquifer.

After development, the discharge to the constant head cells and general head cells along the coast near Onslow County decreases, and inflows to the model from these boundaries increase slightly (well capture). Over the model domain, groundwater withdrawals are relatively small compared to recharge. 


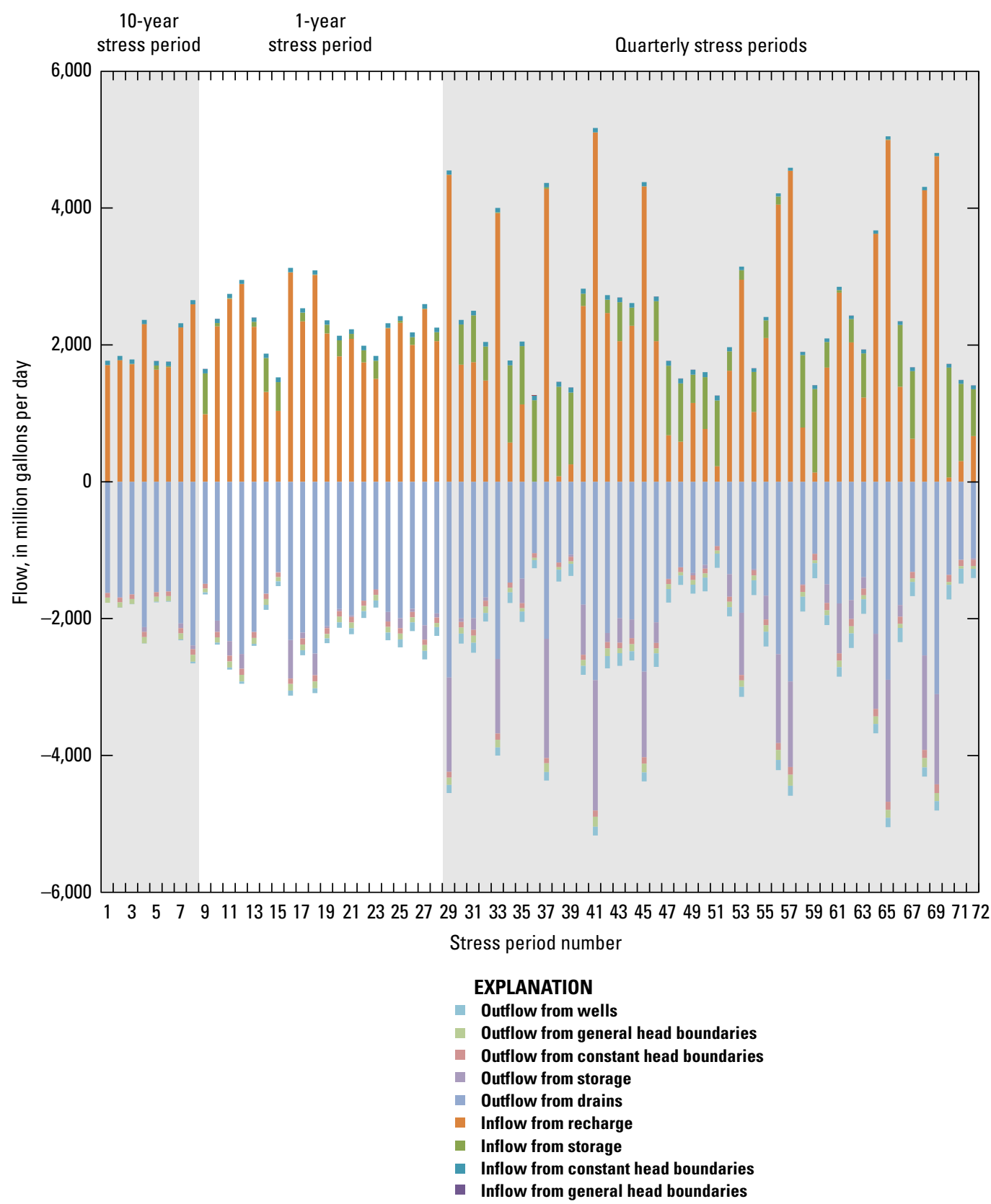

Figure 42. Bar graph showing components of the simulated water budget predevelopment through 2010. 
Table 12. Simulated predevelopment water budget by model layer.

[na, not applicable]

\begin{tabular}{|c|c|c|c|c|c|c|c|c|c|c|c|c|}
\hline \multirow[b]{2}{*}{$\begin{array}{l}\text { Model } \\
\text { layer }\end{array}$} & \multirow[b]{2}{*}{$\begin{array}{l}\text { Hydrogeo- } \\
\text { logic unit }\end{array}$} & \multicolumn{5}{|c|}{ Inflow, in millions of gallons per day } & \multicolumn{6}{|c|}{ Outflow, in millions of gallons per day } \\
\hline & & $\begin{array}{c}\text { Inflow } \\
\text { from } \\
\text { storage }\end{array}$ & $\begin{array}{c}\text { Inflow } \\
\text { from con- } \\
\text { stant head } \\
\text { boundaries }\end{array}$ & $\begin{array}{l}\text { Inflow } \\
\text { from } \\
\text { recharge }\end{array}$ & $\begin{array}{l}\text { Inflow } \\
\text { from } \\
\text { general } \\
\text { head } \\
\text { bound- } \\
\text { aries }\end{array}$ & Total & $\begin{array}{l}\text { Outflow } \\
\text { to } \\
\text { storage }\end{array}$ & $\begin{array}{c}\text { Outflow to } \\
\text { constant } \\
\text { head } \\
\text { boundaries }\end{array}$ & $\begin{array}{c}\text { Out- } \\
\text { flow to } \\
\text { wells }\end{array}$ & $\begin{array}{l}\text { Outflow } \\
\text { to drains }\end{array}$ & $\begin{array}{c}\text { Outflow } \\
\text { to general } \\
\text { head } \\
\text { boundaries }\end{array}$ & Total \\
\hline 1 & $\begin{array}{l}\text { Surficial } \\
\text { aquifer }\end{array}$ & 0 & 34.2 & 1,021 & 0 & 1,055 & 0 & 28.9 & 0 & 1,001 & 33.6 & 1,064 \\
\hline 2 & $\begin{array}{l}\text { Upper } \\
\text { Castle } \\
\text { Hayne } \\
\text { confining } \\
\text { unit }\end{array}$ & 0 & $2.00 \times 10^{-3}$ & 11.9 & 0 & 11.9 & 0 & 6.45 & 0 & na & 11.5 & 17.9 \\
\hline 3 & $\begin{array}{l}\text { Upper } \\
\text { Castle } \\
\text { Hayne } \\
\text { aquifer }\end{array}$ & 0 & 4.70 & na & na & 4.70 & 0 & 1.78 & 0 & na & na & 1.78 \\
\hline 4 & $\begin{array}{l}\text { Lower } \\
\text { Castle } \\
\text { Hayne } \\
\text { confining } \\
\text { unit }\end{array}$ & 0 & $4.51 \times 10^{-5}$ & na & na & $4.51 \times 10^{-5}$ & 0 & $1.47 \times 10^{-5}$ & 0 & na & na & $1.47 \times 10^{-5}$ \\
\hline 5 & $\begin{array}{l}\text { Lower } \\
\text { Castle } \\
\text { Hayne } \\
\text { aquifer }\end{array}$ & 0 & 6.71 & na & na & 6.71 & 0 & 0.97 & 0 & na & na & 0.97 \\
\hline 6 & $\begin{array}{l}\text { Beaufort } \\
\text { confining } \\
\text { unit }\end{array}$ & 0 & $1.28 \times 10^{-4}$ & na & na & 0.00 & 0 & 0.02 & 0 & na & na & 0.02 \\
\hline 7 & $\begin{array}{l}\text { Beaufort } \\
\text { aquifer }\end{array}$ & 0 & 11.7 & na & na & 11.7 & 0 & 6.5 & 0 & na & na & 6.5 \\
\hline 8 & $\begin{array}{l}\text { Peedee } \\
\text { confining } \\
\text { unit }\end{array}$ & 0 & $6.07 \times 10^{-4}$ & na & na & $6.07 \times 10^{-4}$ & 0 & 0.02 & 0 & na & na & 0.02 \\
\hline 9 & $\begin{array}{l}\text { Peedee } \\
\text { aquifer }\end{array}$ & 0 & 2.03 & na & na & 2.03 & 0 & 2.00 & 0 & na & na & 2.00 \\
\hline 10 & $\begin{array}{l}\text { Black Creek } \\
\text { confining } \\
\text { unit }\end{array}$ & 0 & 1.73 & na & na & 1.73 & 0 & 0.00 & 0 & na & na & 0.00 \\
\hline \multirow[t]{3}{*}{11} & $\begin{array}{c}\text { Black Creek } \\
\text { aquifer }\end{array}$ & 0 & 1.43 & na & na & 1.43 & 0 & 2.05 & 0 & na & na & 2.05 \\
\hline & $\begin{array}{r}\text { Total all } \\
\text { layers } \\
\end{array}$ & $\mathbf{0}$ & 62.5 & 1,033 & 0 & 1,095 & $\mathbf{0}$ & 48.7 & 0 & 1,001 & 45.0 & 1,095 \\
\hline & $\begin{array}{c}\text { Percentage } \\
\text { of flow }\end{array}$ & $\mathbf{0}$ & 5.7 & 94.3 & $\mathbf{0}$ & 100 & 0 & 4.4 & 0 & 91.4 & 4.1 & 100 \\
\hline
\end{tabular}


Table 13. Simulated water budget by model layer for stress period 72, fourth quarter, 2010.

[na, not applicable]

\begin{tabular}{|c|c|c|c|c|c|c|c|c|c|c|c|c|}
\hline \multirow[b]{2}{*}{$\begin{array}{l}\text { Model } \\
\text { layer }\end{array}$} & \multirow[b]{2}{*}{$\begin{array}{l}\text { Hydrogeo- } \\
\text { logic unit }\end{array}$} & \multicolumn{5}{|c|}{ Inflow, in millions of gallons per day } & \multicolumn{6}{|c|}{ Outflow, in millions of gallons per day } \\
\hline & & $\begin{array}{l}\text { Inflow } \\
\text { from } \\
\text { storage }\end{array}$ & $\begin{array}{c}\text { Inflow } \\
\text { from con- } \\
\text { stant head } \\
\text { boundaries }\end{array}$ & $\begin{array}{l}\text { Inflow } \\
\text { from } \\
\text { recharge }\end{array}$ & $\begin{array}{l}\text { Inflow } \\
\text { from } \\
\text { general } \\
\text { head } \\
\text { bound- } \\
\text { aries }\end{array}$ & Total & $\begin{array}{l}\text { Outflow to } \\
\text { storage }\end{array}$ & $\begin{array}{c}\text { Outflow to } \\
\text { constant } \\
\text { head } \\
\text { boundaries }\end{array}$ & $\begin{array}{l}\text { Outflow to } \\
\text { wells }\end{array}$ & $\begin{array}{l}\text { Outflow } \\
\text { to drains }\end{array}$ & $\begin{array}{c}\text { Outflow } \\
\text { to gen- } \\
\text { eral head } \\
\text { boundar- } \\
\text { ies }\end{array}$ & Total \\
\hline 1 & $\begin{array}{l}\text { Surficial } \\
\text { aquifer }\end{array}$ & 461 & 40.3 & 667 & 0 & 1,168 & 26.5 & 23.8 & 6.88 & 939 & 27.3 & 1,024 \\
\hline 2 & $\begin{array}{l}\text { Upper } \\
\text { Castle } \\
\text { Hayne } \\
\text { confining } \\
\text { unit }\end{array}$ & 2.01 & 0.76 & 7.09 & 0 & 9.9 & 0.16 & 4.10 & 0 & na & 7.4 & 11.7 \\
\hline 3 & $\begin{array}{l}\text { Upper } \\
\text { Castle } \\
\text { Hayne } \\
\text { aquifer }\end{array}$ & 21.82 & 2.71 & na & na & 24.53 & 4.17 & 7.06 & 27.9 & na & na & 39.2 \\
\hline 4 & $\begin{array}{l}\text { Lower } \\
\text { Castle } \\
\text { Hayne } \\
\text { confining } \\
\text { unit }\end{array}$ & 0.61 & $4.25 \times 10^{-5}$ & na & na & 0.61 & 0.21 & $3.87 \times 10^{-5}$ & $4.76 \times 10^{-3}$ & na & na & 0.21 \\
\hline 5 & $\begin{array}{l}\text { Lower } \\
\text { Castle } \\
\text { Hayne } \\
\text { aquifer }\end{array}$ & 0.43 & 5.68 & na & na & 6.12 & 0.21 & 1.65 & 28.8 & na & na & 30.6 \\
\hline 6 & $\begin{array}{l}\text { Beaufort } \\
\text { confining } \\
\text { unit }\end{array}$ & 0.02 & $2.10 \times 10^{-5}$ & na & na & 0.02 & 0.01 & $1.87 \times 10^{-2}$ & $3.46 \times 10^{-6}$ & na & na & 0.01 \\
\hline 7 & $\begin{array}{l}\text { Beaufort } \\
\text { aquifer }\end{array}$ & 0.11 & 3.60 & na & na & 3.71 & 0.02 & 29.8 & 0.09 & na & na & 29.9 \\
\hline 8 & $\begin{array}{l}\text { Peedee } \\
\text { confining } \\
\text { unit }\end{array}$ & 0.33 & $5.50 \times 10^{-5}$ & na & na & 0.33 & 0.24 & 0.01 & 4.64 & na & na & 4.90 \\
\hline 9 & $\begin{array}{l}\text { Peedee } \\
\text { aquifer }\end{array}$ & 0.17 & 1.46 & na & na & 1.63 & 0.07 & 2.58 & 17.8 & na & na & 20.5 \\
\hline 10 & $\begin{array}{l}\text { Black Creek } \\
\text { confining } \\
\text { unit }\end{array}$ & 3.39 & 1.53 & na & na & 4.92 & 1.21 & 0.01 & 6.13 & na & na & 7.35 \\
\hline \multirow[t]{3}{*}{11} & $\begin{array}{c}\text { Black Creek } \\
\text { aquifer }\end{array}$ & 0.38 & 1.24 & na & na & 1.62 & 2.79 & 7.77 & 42.8 & na & na & 53.4 \\
\hline & $\begin{array}{r}\text { Total all } \\
\text { layers }\end{array}$ & 490 & 57.3 & 674 & $\mathbf{0}$ & 1,221 & 35.6 & 76.8 & 135 & 939 & 34.8 & 1,221 \\
\hline & $\begin{array}{c}\text { Percentage } \\
\text { of flow }\end{array}$ & 40.1 & 4.7 & 55.2 & $\mathbf{0}$ & 100 & 2.9 & 6.3 & 11.1 & 76.9 & 2.8 & 100 \\
\hline
\end{tabular}




\section{Variable-Density Model Predevelopment Conditions}

To convert the constant-density model to the variabledensity model, initial chloride concentrations were developed for each model layer from 1,968 water-quality samples collected at wells from 1941 to 2010. Measured (chloride concentration samples at wells) and calculated (estimates of chloride concentration from specific conductance data at wells) values were used to create initial concentrations for the model layers (figs. 43, 44, and 45). The initial concentration for each cell was calculated using the Inverse Distance Weighting method (Childs, 2004) using the sampled well locations for each layer. Because of the lack of chloride or specific conductance data for the Beaufort aquifer and confining unit, the initial concentrations for the Castle Hayne aquifers were used for these layers. These predevelopment concentrations were then used as a basis for qualitative chloride changes for the hypothetical scenarios.

\section{Variable-Density Model Boundary Conditions}

The boundary conditions used for the variable-density model were identical to the flow model with the addition of chloride concentrations for each boundary cell being added to the general head and constant head boundaries. The chloride concentrations for the general head and constant head boundaries were based on the calculated initial concentrations described above. Additionally, in layers 1 and 2, saltwater concentrations ( 35 grams per liter) were added to the boundaries where seawater is in direct contact with the layer (figs. 46 and 47, respectively).

\section{Additional Hydraulic Properties for Variable- Density Simulation}

Porosity values used to create the variable-density model were derived from values published for similar sediments of the aquifers present in the study area. Provost and others (2006) used values of 0.33 and 0.44 for the aquifers and confining units in Georgia, respectively. Fetter (2001) gave a range of porosity of 0.20 to 0.60 for sediments that are found in North Carolina Coastal Plain aquifers. The porosity values assigned for this study were 0.30 for aquifer layers and 0.45 for confining unit layers. Sensitivity testing indicated that the simulations were not sensitive to porosity. Transverse and longitudinal dispersivity coefficients were set at 1 and $4 \mathrm{ft}$, respectively, for each layer based on default values recommended by Langevin and others (2007).

Although there were not enough chloride data to calibrate porosity or transverse and longitudinal dispersivity coefficients, the calibration statistics were calculated for the variable-density model and were similar to the freshwateronly model calibration statistics. This finding indicates that the estimated extent of freshwater used in calibration of the freshwater-only model was reasonable and that the variabledensity model conversion does not require further calibration. The calibration statistics for water levels for all layers are provided in table 14 for comparison to tables 6-9 (no other comparisons are provided). 


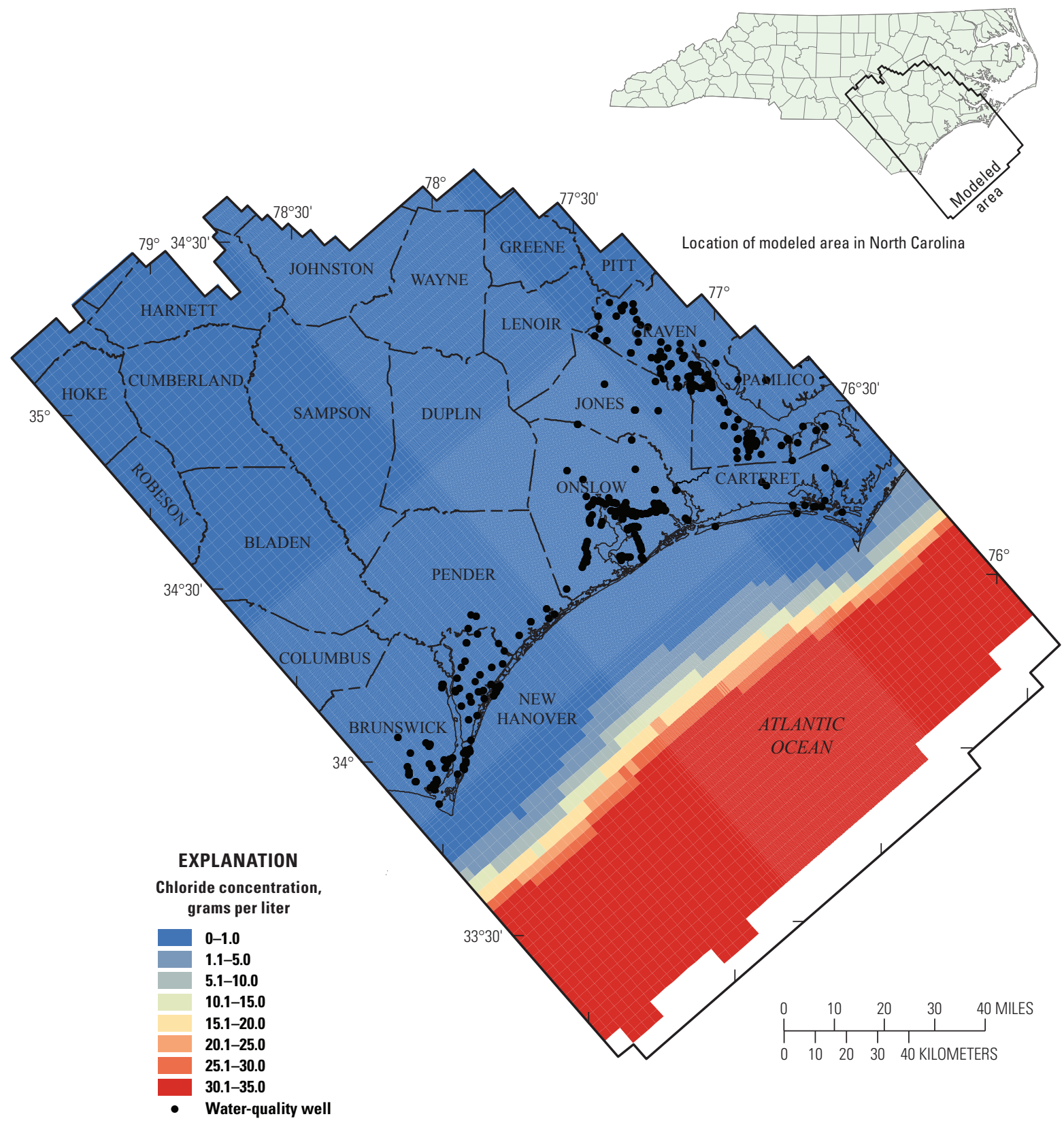

Figure 43. Initial chloride concentrations of Castle Hayne and Beaufort aquifers and confining units. 


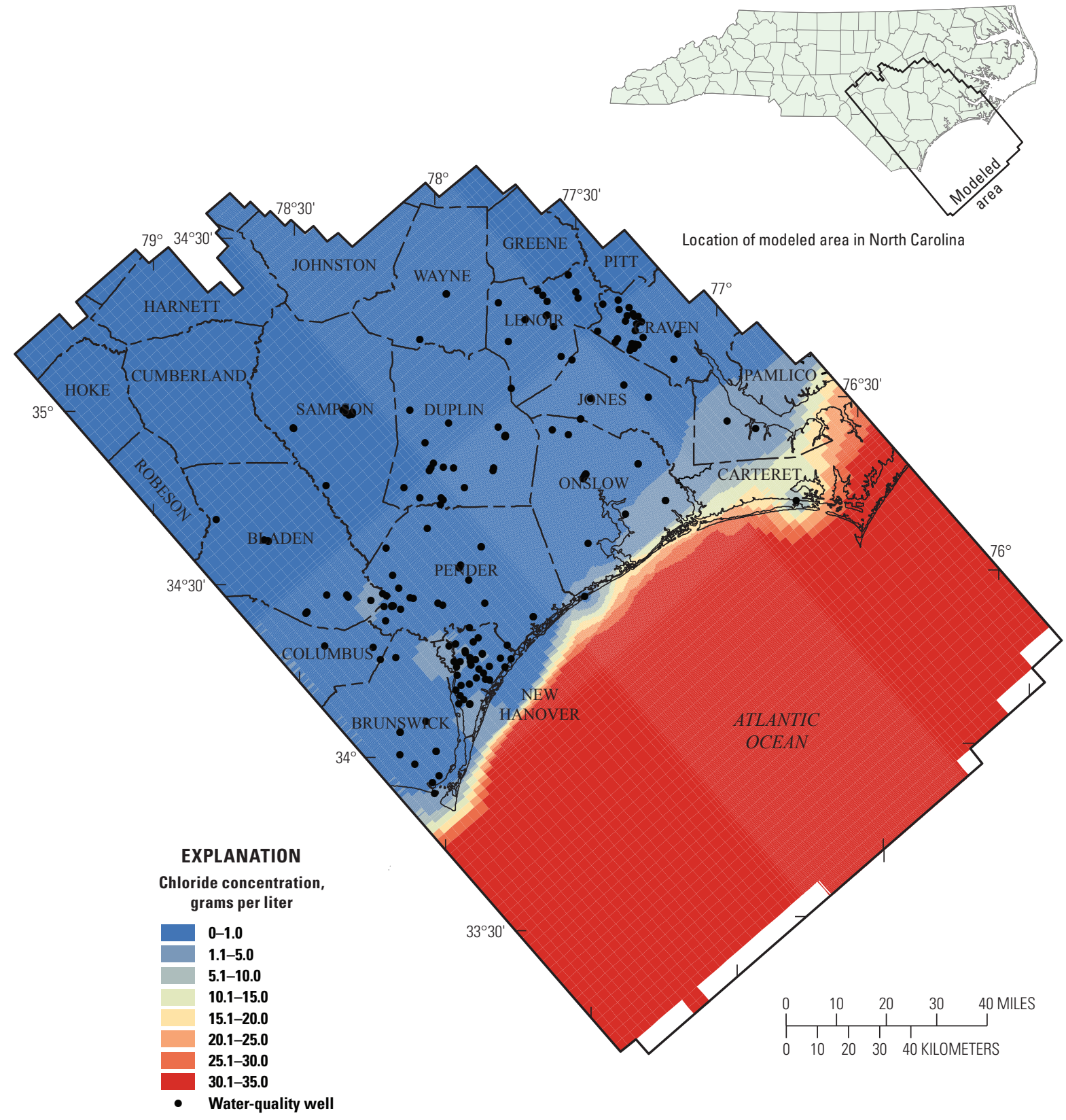

Figure 44. Initial chloride concentrations of the Peedee aquifer and confining unit. 


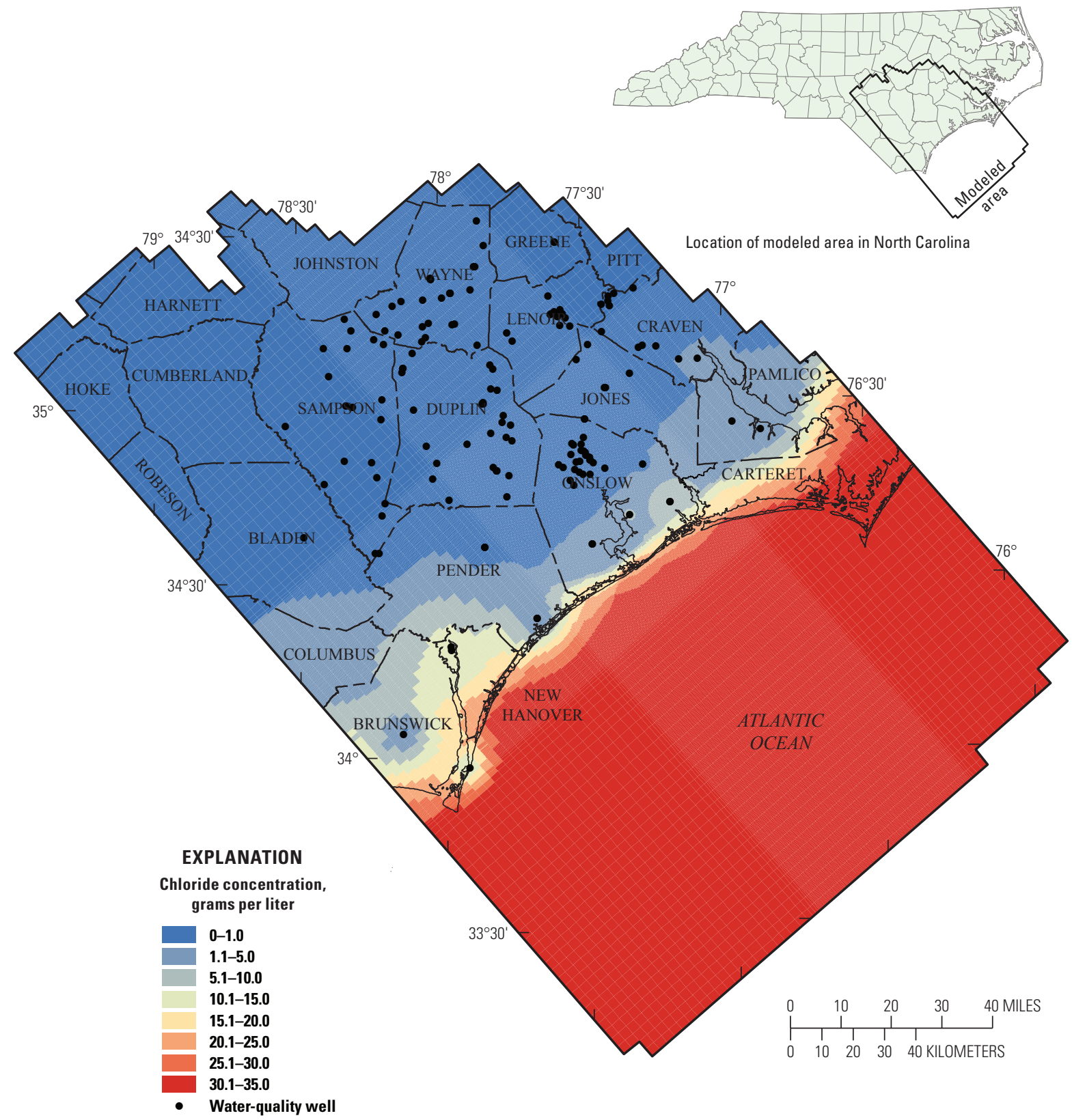

Figure 45. Initial chloride concentrations of the Black Creek aquifer and confining unit. 


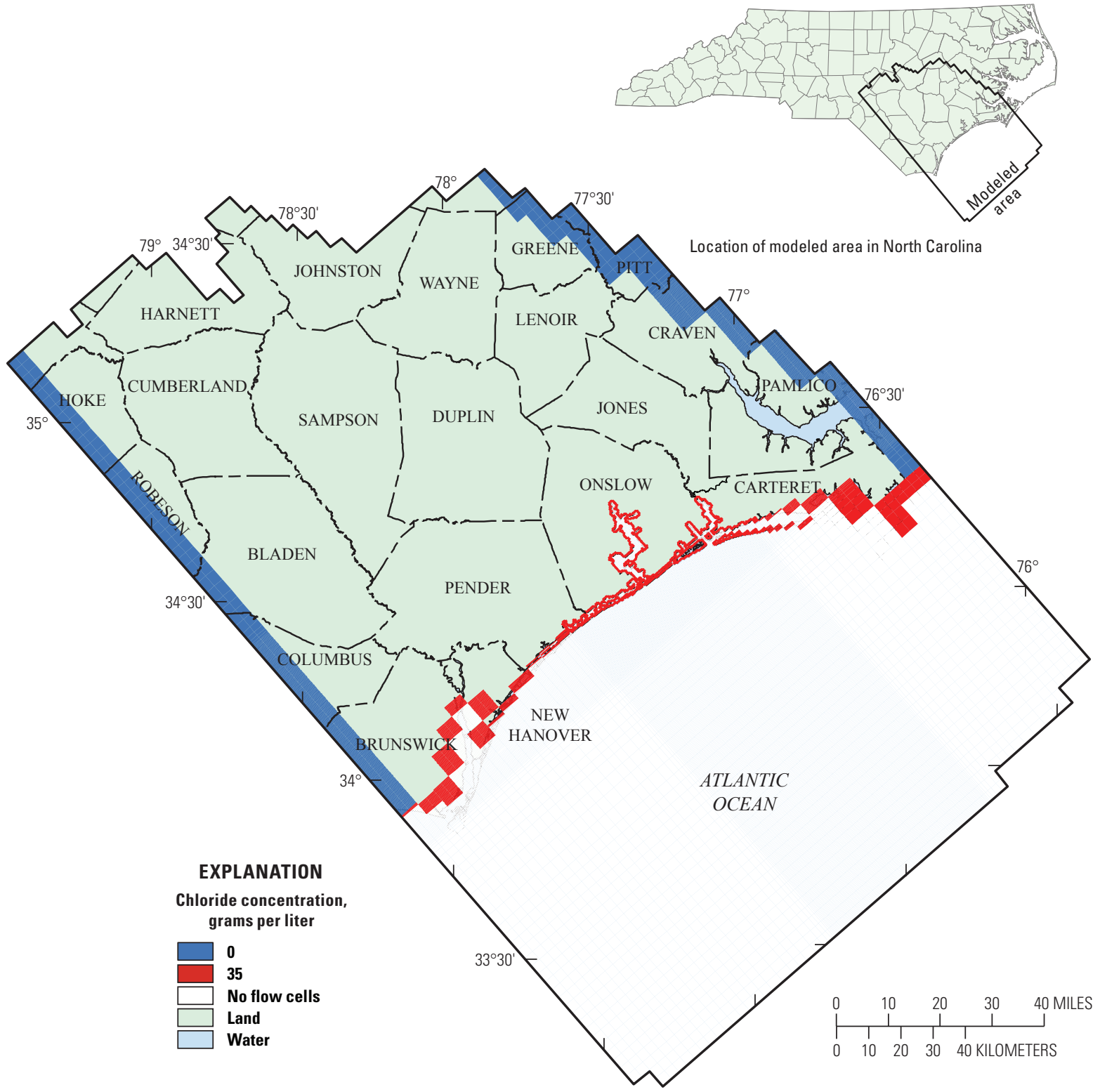

Figure 46. Chloride concentrations for general head and constant head boundaries of layer 1 (surficial aquifer). 


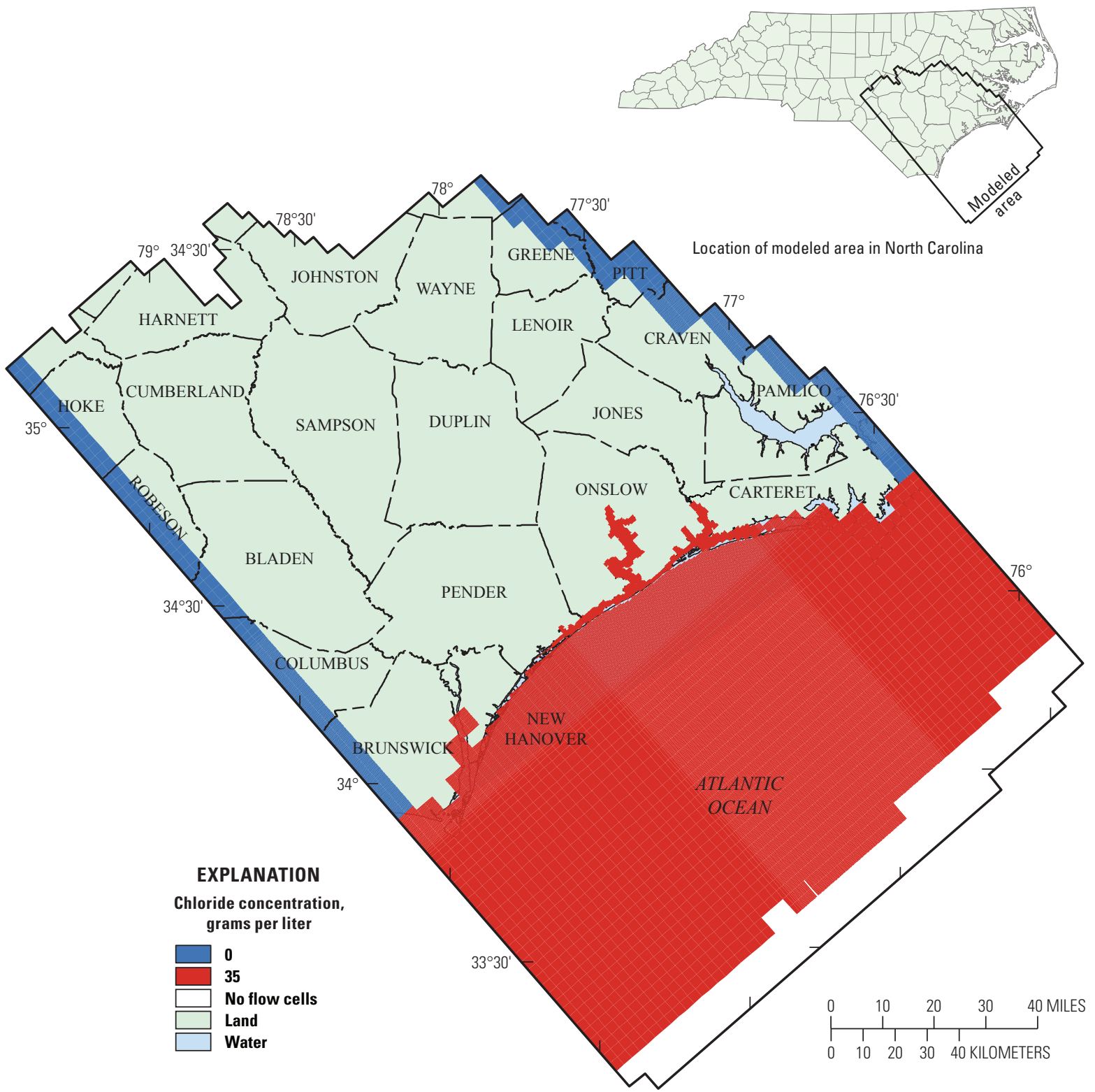

Figure 47. Chloride concentrations for general head and constant head boundaries of layer 2 (upper Castle Hayne confining unit). 
Table 14. Calibration statistics for simulated heads in wells for all layers after conversion to variable-density model.

[na, not applicable]

\begin{tabular}{|c|c|c|c|c|}
\hline Calibration statistic & Predevelopment & 2004 & 2008 & Continuous \\
\hline Number of wells & na & na & na & 92 \\
\hline Number of observations & 140 & 67 & 133 & 4,392 \\
\hline Range in observations (feet) & 337 & 409 & 274 & 372 \\
\hline Minimum weighted residual (feet) & -12.09 & -11.8 & -38.9 & -117 \\
\hline Maximum weighted residual (feet) & 6.21 & 30.6 & 39.4 & 24.7 \\
\hline Mean weighted residual (feet) & -1.39 & -0.10 & 0.45 & -1.15 \\
\hline Weighted residuals standard deviation (feet) & 3.06 & 4.51 & 12.5 & 8.16 \\
\hline Root mean square error of weighted residuals (feet) & 3.36 & 4.51 & 12.5 & 8.24 \\
\hline Percent of simulated values witin the 10 -foot error criteria & 99 & 97 & 62 & 86 \\
\hline Normalized standard deviation (dimensionless) & 0.01 & 0.01 & 0.05 & 0.02 \\
\hline
\end{tabular}

\section{Simulations of Future Conditions with Hypothetical Scenarios}

To simulate future groundwater and chloride concentrations in the study area, the variable-density freshwater and seawater model was used with hypothetical past and future groundwater withdrawal scenarios. These scenarios were developed with the City of Jacksonville, Onslow Water and Sewer Authority, and the United States Marine Corps Base Camp Lejeune, and the scenarios were based on possible groundwater management alternatives that may be considered in the area. The scenarios were designed to assist waterresource managers in the local Onslow County area with their future resource-management decisions.

\section{Hypothetical Scenarios}

Five hypothetical scenarios were created to simulate future groundwater conditions in the study area. The five scenarios represent (1) full implementation of the CCPCUA reductions (phases 1-3); (2) implementation of phase 1 of the CCPCUA reductions; (3) implementation of phases 1 and 2 of the CCPCUA reductions; (4) full implementation of the CCPCUA (scenario 1) with the Onslow Water and Sewer Authority, City of Jacksonville, and United States Marine Corps Base Camp Lejeune pumping their fully permitted amounts from the Castle Hayne aquifer (to maximize the stress to the aquifer) through 2028; and (5) running scenario 1 until the year 2100. Each of these scenarios were run using three additional stress periods; stress period 73 simulates conditions from 2011 to 2013; stress period 74 simulates conditions from 2014 to 2018; and stress period 75 simulates conditions from 2019 to 2028 except for scenario 5, which simulates conditions from 2019 to 2100 . Change in water levels and chloride concentration at the end of the future simulation from the values at the end of 2010 are discussed for each scenario.

\section{Scenario 1}

For scenario 1, the CCPCUA reductions were fully implemented by adding three additional stress periods to the model. The first additional stress period (stress period 73) simulates conditions from 2011 to 2013, where withdrawals from the Black Creek aquifer remained at the same rate permitted in the first phase of the CCPCUA, which is a 25 percent reduction from 2003 permitted withdrawals. The second additional stress period (stress period 74) simulates conditions from 2014 to 2018, and implements the second phase of the CCPCUA reductions. This second phase of the CCPCUA requires an additional 25 percent reduction (50 percent total) in withdrawals from the Black Creek aquifer. The third and final additional stress period added (stress period 75) simulates conditions from 2019 to 2028, and implements the third, and final, phase of the CCPCUA reductions. This third phase of the CCPCUA requires an additional 25 percent reduction ( 75 percent total) in withdrawals from the Black Creek aquifer (North Carolina Division of Water Resources, 2013a). Water use eliminated from the Black Creek aquifer in stress periods 74 and 75 was supplemented by increasing withdrawals from alternative sources (mainly the Castle Hayne aquifer in the study area). Hypothetical wells in the upper and lower Castle Hayne aquifers were added to existing well field locations throughout the study area for this and all subsequent scenarios. The increased withdrawals were based on population projections (North Carolina Division of Water Resources, 2013b) and the amount of reductions required by the CCPCUA.

By 2028, simulated water levels for scenario 1 in the Black Creek aquifer recovered an average of $25.0 \mathrm{ft}$ in the study area, with the maximum recovery in one cell of $140.2 \mathrm{ft}$ (fig. 48C). Conversely, simulated water levels in the upper and lower Castle Hayne aquifers declined an average of 3.2 and $3.6 \mathrm{ft}$ (figs. $48 A$ and $B$ ), respectively, in the study area. Simulated chloride concentrations in the study area by the end of 2028 under scenario 1 were relatively unchanged. 

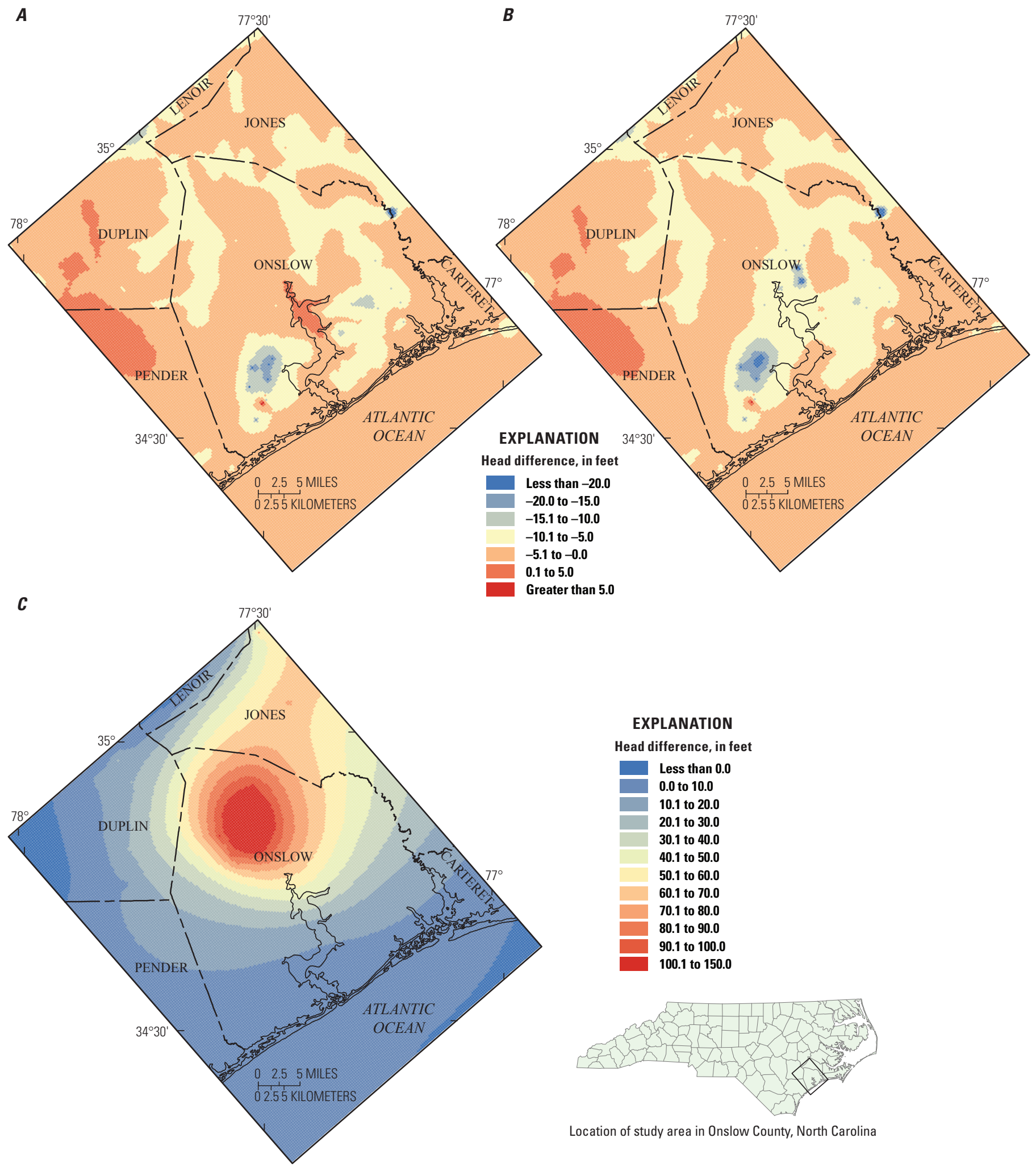

Figure 48. Computed change of simulated water levels between 2010 and 2028 for scenario 1 in the $(A)$ upper Castle Hayne aquifer, $(B)$ lower Castle Hayne aquifer, and $(C)$ Black Creek aquifer. 


\section{Scenario 2}

The objective of scenario 2 was to simulate the long-term effects of only phase 1 of the CCPCUA reductions ( 25 percent reduction from 2003 permitted withdrawals). In scenario 2, hypothetical withdrawals created for scenario 1 for stress period 73 remained constant throughout stress periods 74 and 75. As a result in 2028, simulated water levels in the Black Creek aquifer recovered an average of $6.7 \mathrm{ft}$ in the study area, with a maximum recovery of $41.9 \mathrm{ft}$ (fig. $49 \mathrm{C}$ ). Simulated heads in the upper and lower Castle Hayne aquifers declined $2.9 \mathrm{ft}$ and $3.1 \mathrm{ft}$, respectively, as a result of simulated increased pumping from the aquifer. Simulated chloride concentrations in the study area in 2028 under scenario 1 were relatively unchanged.

\section{Scenario 3}

Scenario 3 builds on scenario 2 by adding the phase 2 (additional 25 percent, total 50 percent from 2003 permitted withdrawals) reduction of Black Creek aquifer reductions mandated for the CCPCUA at the end of 2013 and runs through 2028. In this scenario, hypothetical withdrawals created for stress period 74 , remained constant for stress period 75. To compensate for reductions of Black Creek aquifer withdrawals in the study area, hypothetical wells in the upper and lower Castle Hayne aquifers were added to existing well field locations throughout the study area. By 2028, simulated water levels in the Black Creek aquifer recovered an average of $14.0 \mathrm{ft}$ in the study area, with a large area of recovery of greater than $60 \mathrm{ft}$ focused in northern Onslow County with a maximum recovery of $81.6 \mathrm{ft}$ (fig. 50C). Because of increased withdrawals in the upper and lower Castle Hayne aquifers, simulated water levels in the study area in those aquifers declined an average of 2.6 and $2.9 \mathrm{ft}$, respectively. Simulated chloride concentrations in the study area were relatively unchanged by 2028 under scenario 3 .

\section{Scenario 4}

Scenario 4 is a modification of scenario 1 , where withdrawals in the Castle Hayne aquifer in Onslow County are made at their fully permitted amount in stress period 75 . This hypothetical scenario results in an additional 2.8, 15.0, and 3.0 Mgal/d of withdrawals from the Castle Hayne aquifer well fields of the City of Jacksonville, United States Marine Corps Base Camp Lejeune, and Onslow Water and Sewer Authority, respectively. By the end of 2028, this scenario resulted in simulated heads in the Black Creek aquifer that were relatively unchanged from scenario 1 (an average recovery of $24.3 \mathrm{ft}$ and a maximum of $140 \mathrm{ft}$ ). However, drawdowns in the study area in the upper and lower Castle Hayne aquifers had a mean of $5.3 \mathrm{ft}$ and $6.0 \mathrm{ft}$, respectively, with broad cones of depression present where the additional withdrawals were added (fig. 51). Simulated chloride concentrations in the study area for 2028 under scenario 4 were relatively unchanged.

\section{Scenario 5}

Scenario 5 is also a modification of scenario 1 where the only change was that the final stress period (stress period 75) was extended an additional 72 years to 2100 . The objective of this scenario is to test the simulated long-term effects of the CCPCUA reductions on groundwater levels and chloride estimates. By the end of 2100, water levels in the Black Creek aquifer recovered an average of $27.3 \mathrm{ft}$, with a maximum recovery of $146.9 \mathrm{ft}$ (fig. 52). Because of increased pumping in the upper and lower Castle Hayne aquifers, water levels declined an average of 3.5 and $3.8 \mathrm{ft}$, respectively, in scenario 5 and 3.2 and 3.6, respectively, in scenario 1 for these aquifers.

The additional time simulated in scenario 5 resulted in changes to simulated chloride. In the upper Castle Hayne aquifer, simulated chloride concentrations increased near the coast and beneath the White Oak River (fig. 53A). These increases on the coast are the result of water with higher chloride concentrations migrating laterally and downward from the saltwater boundary present in layer 2 (upper Castle Hayne confining unit). In the lower Castle Hayne aquifer, the simulated increases in chloride concentrations occurred further inland beneath the New River, as well as beneath the White Oak River (fig. 53B). The increases in chloride concentrations in the lower Castle Hayne aquifer likely are a result of the upconing of water with higher chloride concentrations from the underlying Peedee aquifer. 

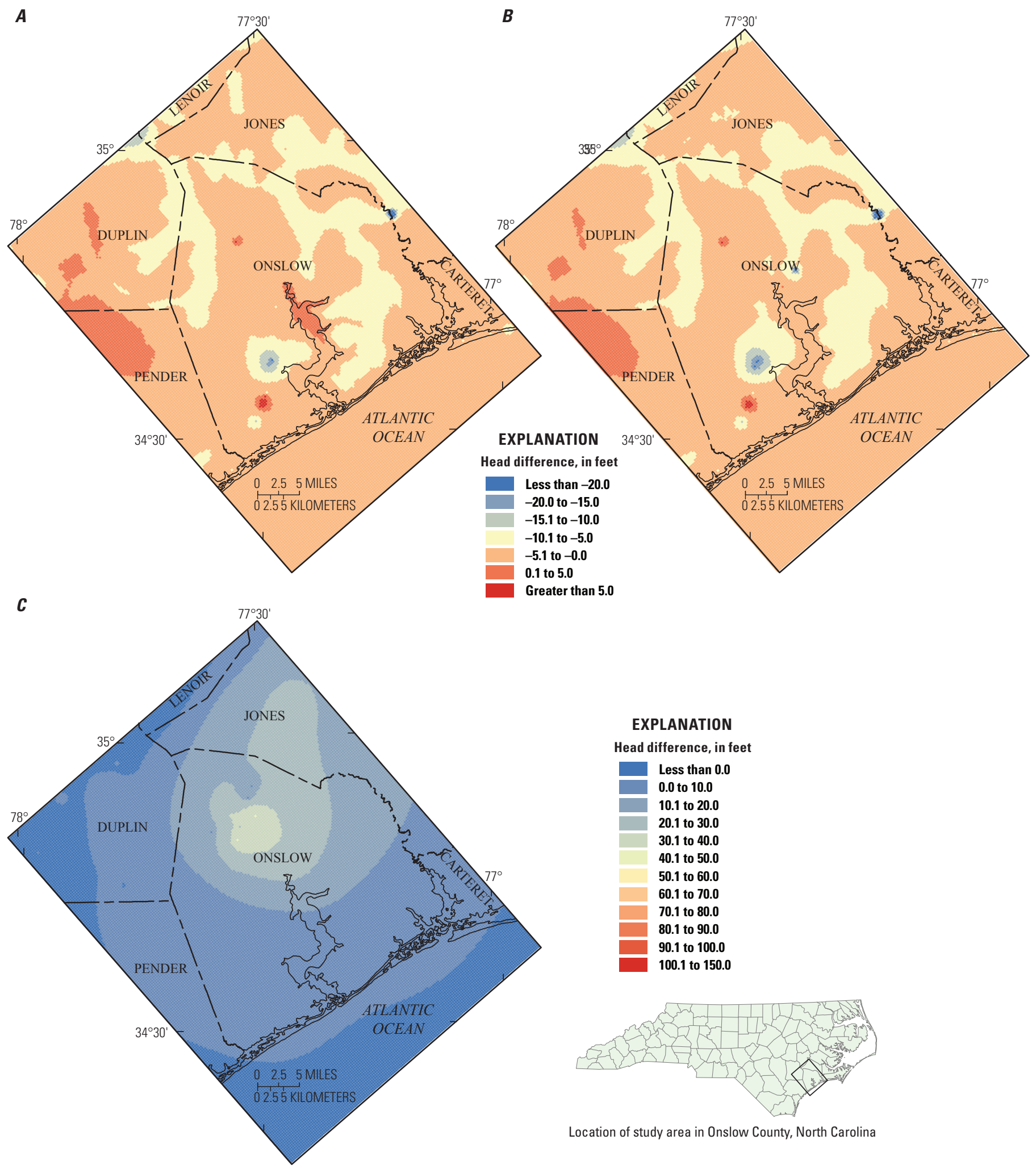

Figure 49. Computed change of simulated water levels between 2010 and 2028 for scenario 2 in the $(A)$ upper Castle Hayne aquifer $(B)$ lower Castle Hayne aquifer, and (C) Black Creek aquifer. 


$$
\text { A }
$$

\section{$\boldsymbol{A}$$$
\boldsymbol{A}
$$
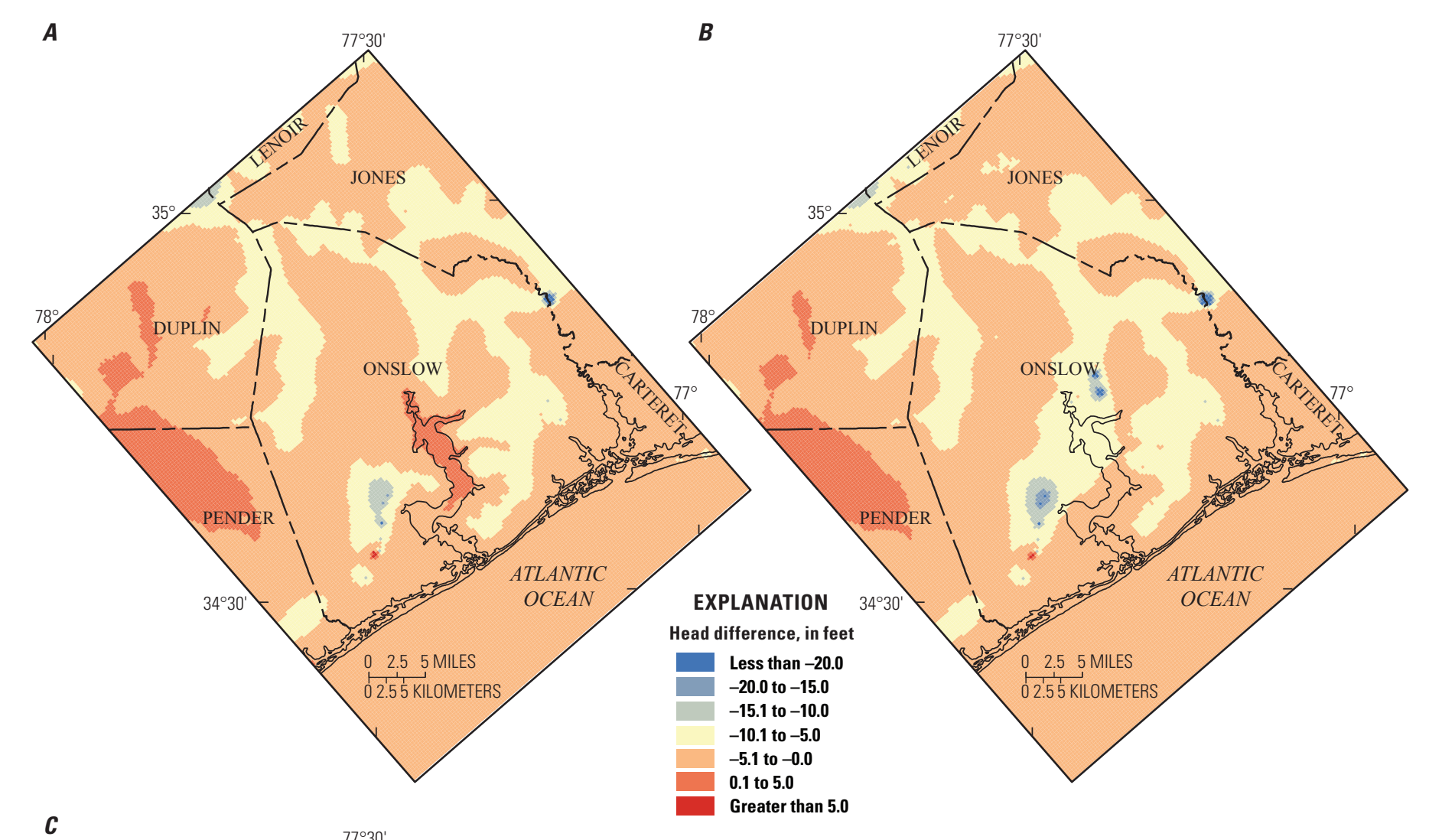

B

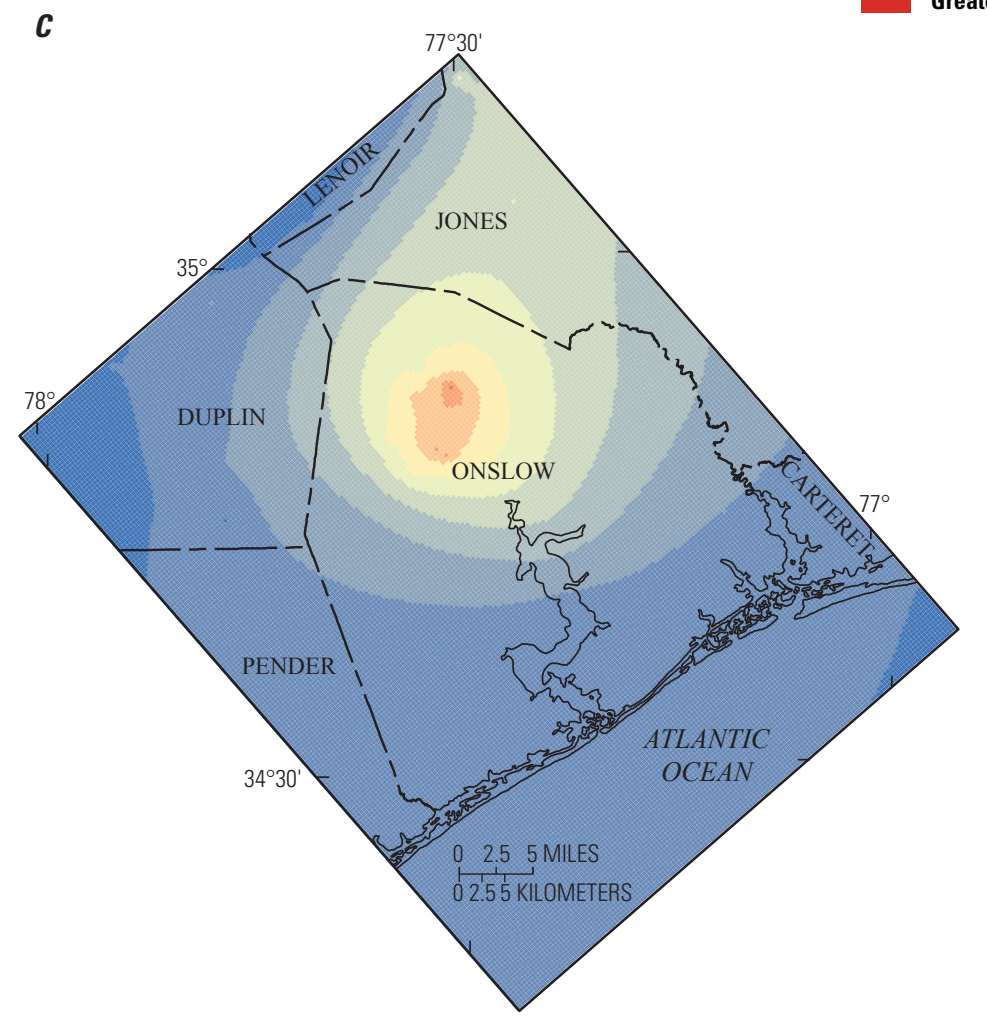

EXPLANATION

Head difference, in feet

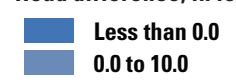

0.0 to 10.0

10.1 to 20.0
20.1 to 30.0

30.1 to 40.0

40.1 to 50.0

50.1 to 60.0

60.1 to 70.0

70.1 to 80.0

80.1 to 90.0

90.1 to 100.0

100.1 to 150.0

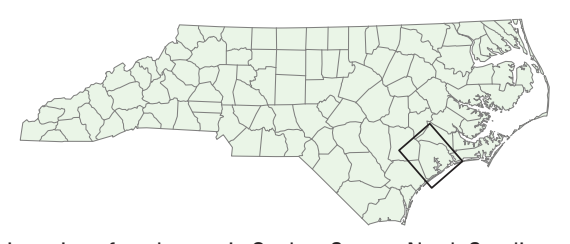

Location of study area in Onslow County, North Carolina

Figure 50. Computed change of simulated water levels between 2010 and 2028 for scenario 3 in the $(A)$ upper Castle Hayne aquifer; $(B)$ lower Castle Hayne aquifer; and $(C)$ Black Creek aquifer. 

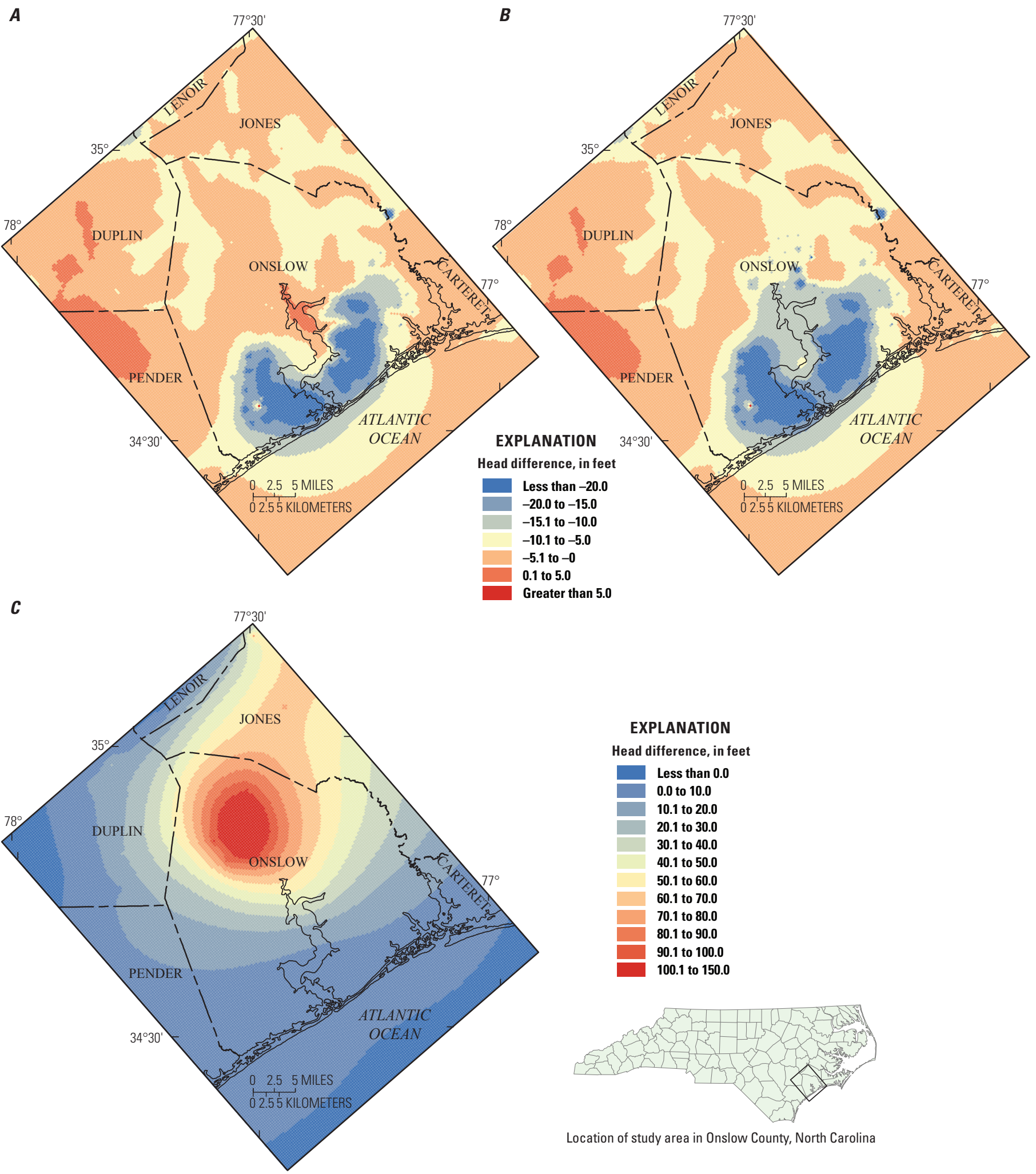

Figure 51. Computed change of simulated water levels between 2010 and 2028 for scenario 4 in the $(A)$ upper Castle Hayne aquifer, $(B)$ lower Castle Hayne aquifer and $(C)$ Black Creek aquifer. 
$\boldsymbol{A}$

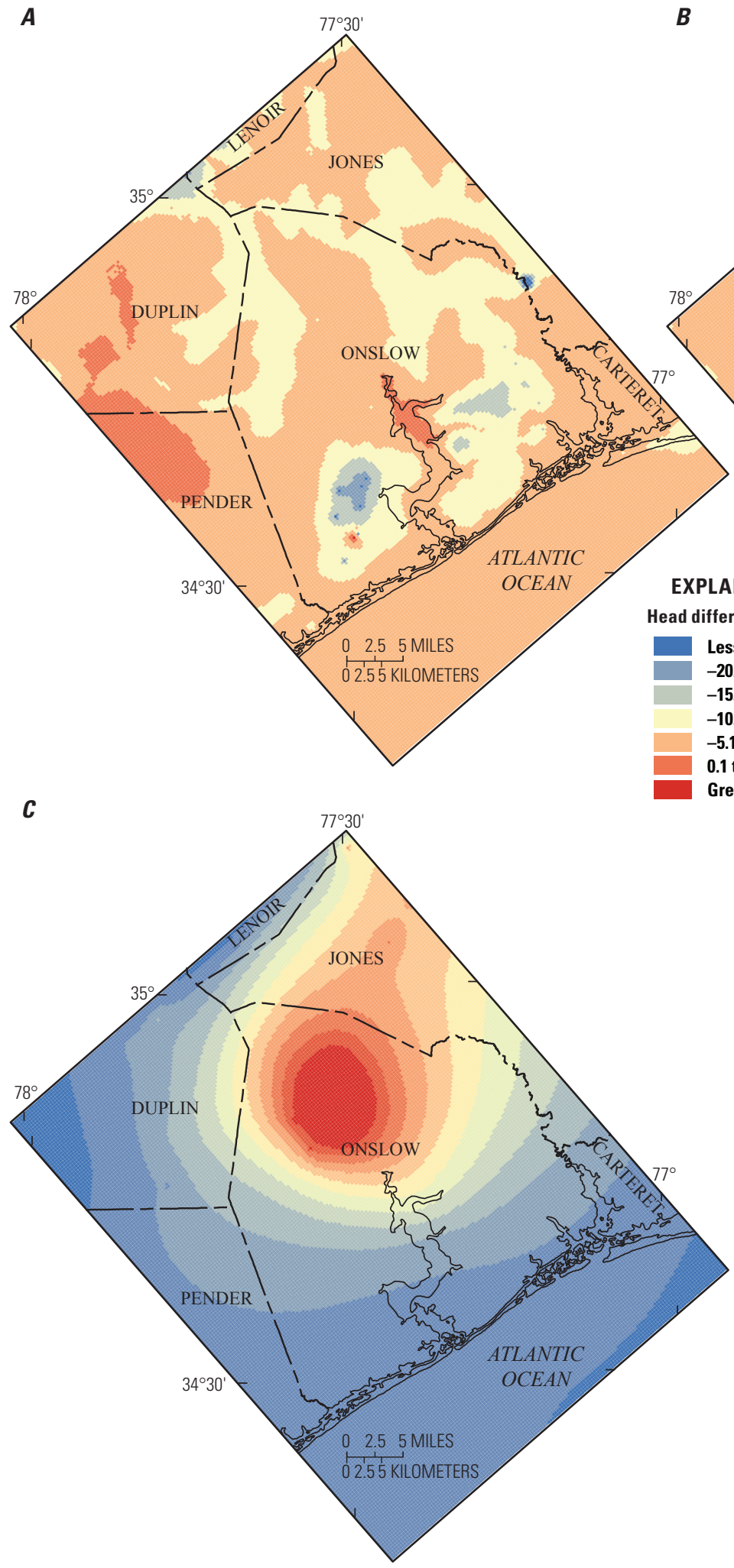

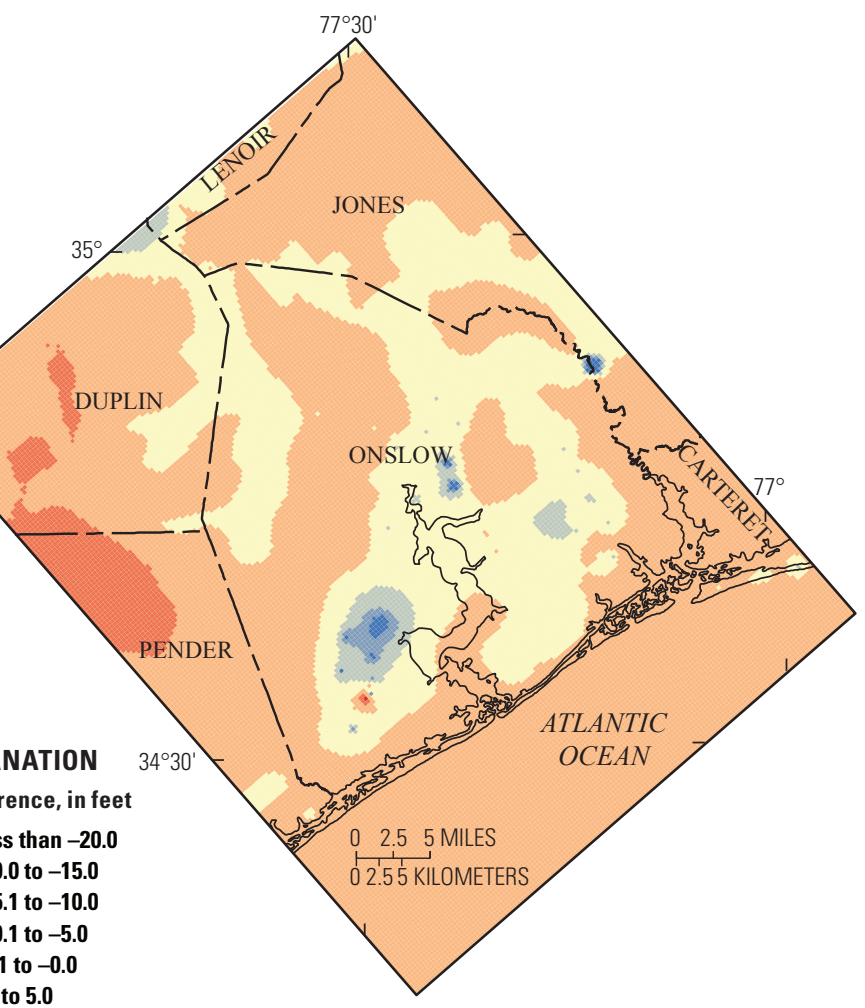

.1 to 5.0

reater than 5.0

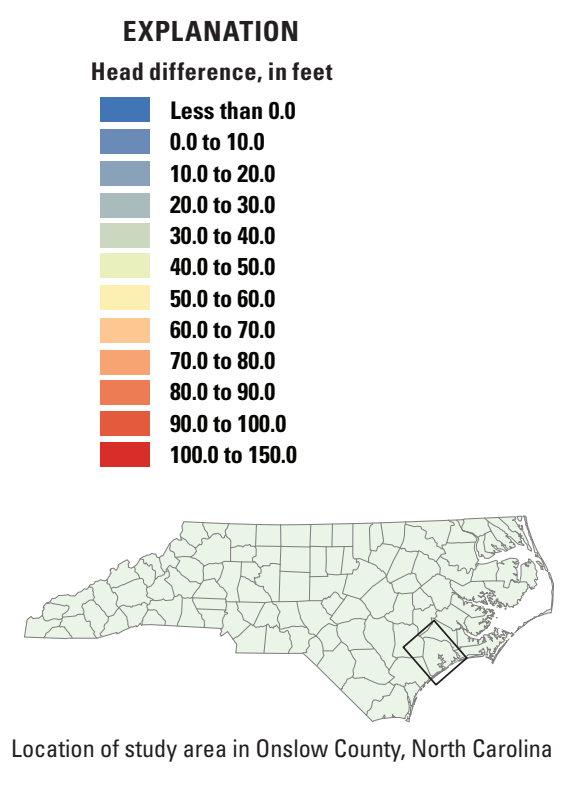

Figure 52. Computed change of simulated water levels between 2010 and 2100 for scenario 5 in the $(A)$ upper Castle Hayne aquifer, $(B)$ lower Castle Hayne aquifer, and $(C)$ Black Creek aquifer. 


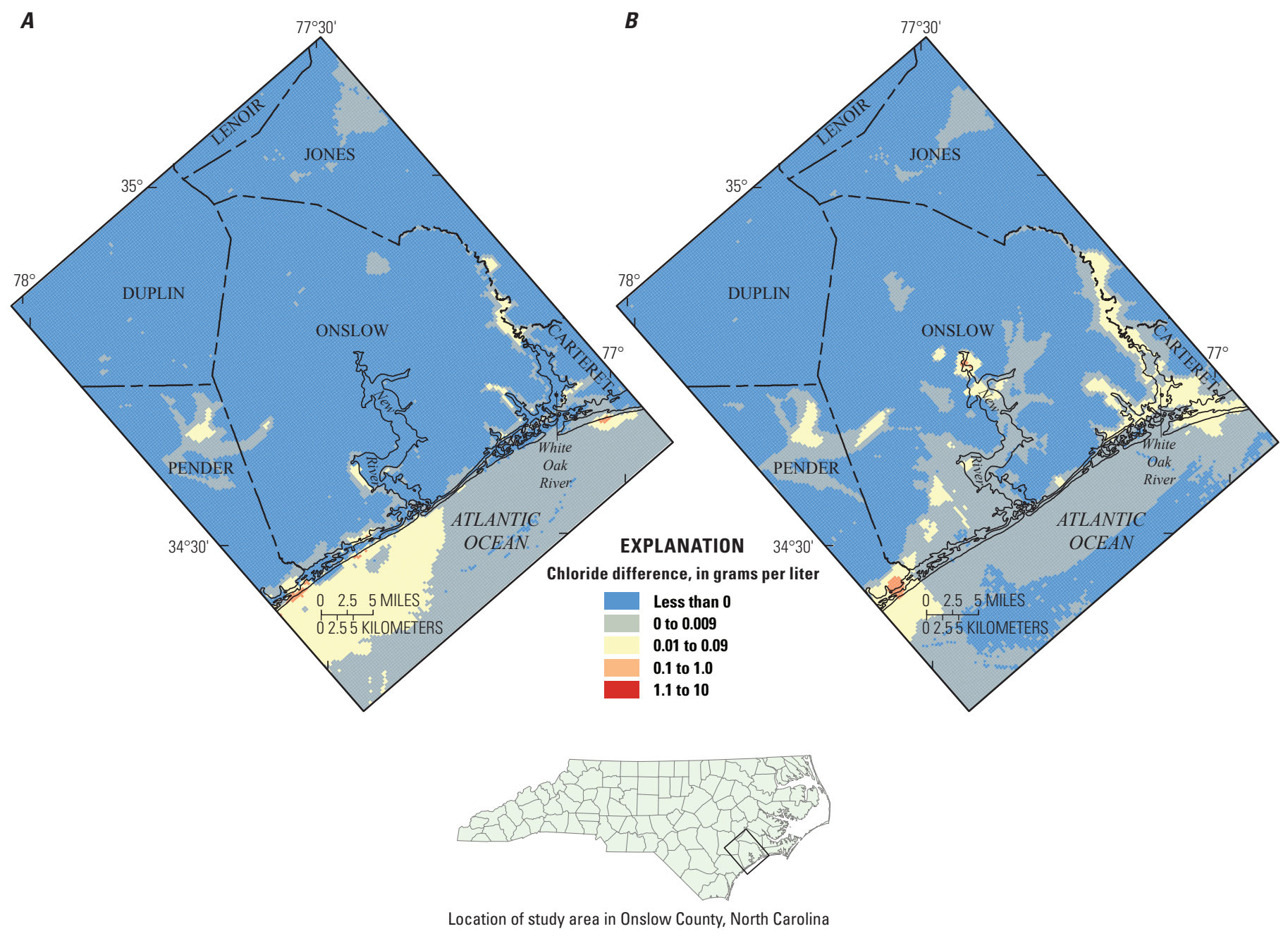

Figure 53. Computed change of simulated chloride levels between 2010 and 2100 for scenario 5 in the $(A)$ upper Castle Hayne aquifer, and the $(B)$ lower Castle Hayne aquifer. 


\section{Model Limitations}

Numerical groundwater models require simplification of complex aquifer systems for which all details are not known. These simplifications can lead to model uncertainty and add to accuracy errors when making predictions of future conditions. The major simplifications in the development of this model were model discretization (both spatial grid size and unit layering), the initial set of hydraulic properties assigned to parameters in calibration, the assignment of boundary conditions, and uncertainty in the location of the freshwater/ saltwater interface. Additionally, estimated net groundwater recharge, reported withdrawals, and observations used in the model calibration may have inaccuracies, which affect calibration and the resulting hydraulic properties for each layer and simulated water budgets.

This model was spatially discretized into 11 layers (6 aquifers and 5 confining units) (figs. 9 and 10) using a variably spaced grid with cell sizes ranging from $2 \mathrm{mi}^{2}$ to $0.25 \mathrm{mi}^{2}$ (fig. 11). The variably spaced grid allows a very fine discretization over the local Onslow County area, with the larger model cells or cells with large aspect ratios (long side divided by short side) being outside of Onslow County. Thus, this model discretization is more mathematically accurate in Onslow County where the aquifers are represented by a smaller, equally spaced grid with small aspect ratios. Therefore, this model should not be used for the prediction of aquifer conditions in areas outside of Onslow County.

The Coastal Plain aquifers of North Carolina are a complex system of interlayered sediments. Generally, these sediments have been grouped into aquifers and confining units that have similar hydraulic properties. Within these aquifers, however, many semi-confining units may exist, creating multiple aquifers. Harned and others (1989) delineated as many as seven confining beds in the Castle Hayne aquifer beneath Camp Lejeune. For the current study, the Castle Hayne aquifer was divided into two aquifers - the upper and lower Castle Hayne - because of the lack of stratigraphic and hydraulic information over the larger Onslow County area. For the scope of this study, the Castle Hayne aquifer was simplified to best meet the objectives of the countywide study. Other aquifers and confining units were similarly simplified. The Upper and Lower Cape Fear aquifers were not simulated in this study because of the lack of use of these aquifers in the study area and the limited interaction between these aquifers and confining units with the overlying Black Creek aquifer (Campbell and Coes, 2010) (fig. 3). These simplifications in aquifer and confining units are reasonable for a county or subregional scale area $\left(1,000 \mathrm{mi}^{2}\right)$, such as this study, but are inadequate for a local site-scale model for the purpose of solute transport.

Hydraulic properties required by the model include hydraulic conductivity, vertical anisotropy, specific storage for confined aquifers (layers 2-11), and specific yield for unconfined aquifers (layer 1). Hydraulic conductivity was calibrated using initial values from published values and aquifer tests in the study area. Although hydraulic conductivity data exist for aquifer layers (results of aquifer tests), the data points are clustered around pumping centers leaving little to no data in surrounding areas or in aquifers that are not developed. For this reason, pilot points were used in the calibration process to create a smoothly varying distribution of hydraulic conductivity in each parameter zone. Few data are available for specific storage in the model area. For this reason, specific storage was calibrated using simplified zones. The final distribution of hydraulic properties was based on available data and reasonable ranges from other published reports for the respective aquifers or confining units. However, it would be ill advised to assume that these data are accurate and that a new well drilled would yield the exact hydraulic conductivity when tested as shown on these illustrations herein.

Boundary conditions for the model were selected to best represent natural hydraulic conditions. The lateral northeast and southwest constant head boundaries were placed along groundwater flow paths, which could possibly shift if groundwater development near these boundaries alters the potentiometric surface. Model testing of the flow-path boundary indicated that the head assignment would have minimal effect on water levels in Onslow County. The northwestern no-flow boundary is located along the Fall Line, where units of the updip Coastal Plain aquifers crop out. The southeast no-flow boundary is located offshore, beyond the freshwater/saltwater interface. Both of these no-flow boundaries are considered to be natural hydraulic boundaries in the groundwater system.

The location of the freshwater/saltwater interface used for the initial chloride concentrations in the model were statistically calculated from available chloride and specific conductance measurements and previously published maps of the freshwater/saltwater interface. The exact location of the interface is not fully understood, but the location used appears reasonable. The effect of inaccuracies in the initial chloride concentration data was not tested. For this reason and the lack of long-term chloride monitoring, the variable-density SEAWAT model is used for illustrative purposes only and is not intended to quantitatively define salinity in the aquifer system.

Groundwater withdrawals are a source of uncertainty in the model. Groundwater users in North Carolina who use less than 100,000 gallons per day are not required to report their withdrawals to State regulatory agencies. In addition, the State of North Carolina does not require that groundwater withdrawn for agricultural purposes be reported. However, after 1985 estimates for livestock, irrigation, and domestic pumpage are available every 5 years. Prior to 1985 , simulated withdrawals only include commercial, industrial, mining, and public-supply wells and do not include domestic, livestock, or irrigation withdrawals. The more recent withdrawal data are more accurate than predevelopment data and so most of the calibration datasets are for more recent time periods. Thus the withdrawals were not adjusted through parameter estimation.

Groundwater hydraulic head data used as observation targets in the calibration of the model have uncertainty. Land-surface elevation varies widely in accuracy depending on the method used in its determination at each well. The 
land-surface elevation errors potentially result from either determining the elevation using a topographic map, which is assumed to have an error of one half of the contour interval of the topographic map, or using surveying methods, which can be accurate to thousandths of a foot. Another source of poor calibration introduced with groundwater levels is the clustering of data points. Data are most prevalent in populated areas where groundwater use is highest and lacking in rural areas where large production wells are not as numerous. The clustering focused the model calibration on the areas with numerous data points, while areas with little to no data were ignored. Attempts were made to avoid the clustering of data points in the modeling process, but the lack of data in some areas made this unavoidable. Additional errors may have been introduced using groundwater levels collected between 1900 and 1980 as predevelopment values. Because of the general lack of historic measurements reported in previous studies, groundwater-level measurements collected before 1980 were considered predevelopment for this study. Groundwater withdrawals began in the model area in the 1940s, which suggests that some of the water-level observations used may not reflect true predevelopment conditions. For this reason, these measurements were given lower weights during the transient calibration.

Stream base flow calculated for use as an upper estimate of the observed groundwater discharge was reasonably simulated by the model for two of three streamgages. Base flow from hydrograph separation may overestimate groundwater discharge at a watershed scale in this flat, swampy terrain. Additionally, the model cell sizes range from 0.25 to $2 \mathrm{mi}^{2}$. As model cell sizes become large, recharge and discharge that in reality may occur within the cell at a local scale cannot be simulated in the model, resulting in simulated base flow being less than actual base flow. This model was not designed to address the details of groundwater/surface-water interactions; however, the base-flow observations help constrain the parameter estimation problem.

\section{Summary and Conclusions}

Since 1980, water levels in aquifers in rocks of Cretaceous age in the central region of the North Carolina Coastal Plain have declined by as much as $200 \mathrm{ft}$ as a result of groundwater withdrawals. In 2001, the North Carolina Department of Water Resources established rules for this area, known as the Central Coastal Plain Capacity Use Area (CCPCUA), which mandate groundwater users who withdraw more than 100,000 gallons per day from wells in the Cretaceous aquifers are subject to a water-use reduction of as much as 75 percent in three phases over a 16-year period from 2008 to 2018. Groundwater suppliers in Onslow County are subject to these reductions of groundwater withdrawals from the Black Creek aquifer, which is the primary Cretaceous aquifer used in the area. To compensate for reduction in groundwater withdrawals from the Black Creek aquifer, water suppliers have developed new well fields that tap the shallower Castle Hayne aquifer. The increased development of the Castle Hayne aquifer has raised concerns about water-level declines in addition to potential lateral saltwater migration along the coast and upward leakage of brackish water from deeper aquifers.

To better understand the effects the future changes in groundwater withdrawals may have on the aquifer systems in and around Onslow County, a three-dimensional flow model was developed using the MODFLOW-2000 code. Although the model was focused on the Onslow County area, the boundaries extend to natural groundwater divides to the northeast and southwest and to no-flow boundaries along the Fall Line to the northwest and the freshwater/saltwater interface offshore to the southeast.

The model was calibrated to decadal stress periods from 1900 to 1980 , annual stress periods from 1980 to 2000, and quarterly stress periods from 2000 to 2010 . The steady-state condition of 1900-1910 represents predevelopment conditions when groundwater was not used extensively in the area as a source of water and serves as the initial conditions for the subsequent transient stress periods, which represent variable groundwater withdrawals and recharge rates to 2010. The model calibration used the parameter estimation code PEST to adjust hydraulic properties and recharge rates to obtain a reasonable fit for observed groundwater levels and estimated stream base flow.

Groundwater levels used to calibrate the model were divided into four groups: predevelopment, 2004, 2008, and wells having continuous data (having two or more measurements from the same well). Measurements for wells falling outside of the study area were given a low weight in the model calibration to focus the calibration on the study area. In addition, measurements used to calibrate the predevelopment time period were also given a low weight because it is unclear whether or not all of the predevelopment water levels accurately represented a period prior to pumping from the aquifers in the study area. For all periods compared, the overall model fit to water levels exceeded the following calibration criteria: majority of weighted residuals less than $10 \mathrm{ft}$; mean weighted residual close to zero; and normalized standard deviation less than 0.1 (standard deviation divided by range of observed data, dimensionless). Calculated and simulated mean annual base flows were compared at three long-term USGS streamgages in the study area. Average simulated base flows at the Trent River near Trenton, North Carolina, and the New River near Gum Branch, North Carolina, matched the average observed base flow within an order of 2, while simulated average base flow to the Northeast Cape Fear River near Chinquapin, North Carolina, did not match within a factor of 2 (but was within the same order of magnitude).

Composite-scaled sensitivities from calibration indicate that the model is sensitive to the majority of the recharge multipliers. The sensitivity analysis also shows that pilot points for hydraulic conductivity and vertical anisotropy within the 
detailed area of the model, where withdrawals are greatest, generally have the highest sensitivities. Greater sensitivity increases the likelihood that changes in those parameters can affect simulated water levels and be estimated.

The calibrated flow model was converted to a variabledensity model using the SEAWAT-2000 code to simulate chloride concentrations in the study area. The variable-density model used measurements of chloride and specific conductance to estimate predevelopment salinity conditions. The model was created to illustrate potential saltwater movement in the future scenarios. Wells with long-term variable chloride data were not available to calibrate porosity and dispersivity coefficients for the SEAWAT model. However, the same calibration statistics used for the freshwater-only model were calculated, and the SEWAT model fit and water budget were found to be similar to the freshwater-only model. Therefore, the future variable-density model results should only be used qualitatively, and future testing and refinement of this model would be warranted with additional data.

Five scenarios were created to simulate future groundwater conditions in the Onslow County area: (1) full implementation of the CCPCUA rules (withdrawal reduction phases 1-3) and simulated through 2028; (2) implementation of only phase 1 of the CCPCUA rules and simulated through 2028; (3) implementation of only phases 1 and 2 of the CCPCUA rules and simulated through 2028; (4) full implementation of the CCPCUA rules; however, withdrawals from the Castle Hayne aquifer in Onslow County are at their fully permitted amount in the final stress period and simulated through 2028; and (5) full implementation of the CCPCUA rules and simulated through 2100. Results from the scenarios show significant recovery in the Black Creek aquifer of as much as $140 \mathrm{ft}$ by 2028 , if all three phases of reduction occur as part of the CCPCUA rules in Onslow County. Furthermore, as development of the Castle Hayne aquifer was increased in the scenarios to compensate for the reductions from the Black Creek aquifer, cones of depression arose around pumping centers in the Castle Hayne aquifer. For scenarios 1-4, little to no significant changes in chloride concentrations were observed, but chloride concentrations did increase in the upper and lower Castle Hayne aquifers near the coast for scenario 5 by the year 2100 .

The model developed for this study was designed to focus on the Onslow County area. The variable grid spacing and aquifer units are much more generalized outside of the Onslow County area and thus the quantitative use of the model should be limited to Onslow County. The simplifications in aquifers and confining units are reasonable for a county or subregional scale area $\left(1,000 \mathrm{mi}^{2}\right)$, such as this study, but inadequate for a local site-scale model for the purpose of solute transport. Although the final distribution of hydraulic properties fits within reasonable ranges of properties for each unit and the calibration statistics indicate sensitivity of these parameters, the maps presented in this report should not be used to predict well yields.

\section{References Cited}

Badon-Ghijben W., 1888, Nota in verband met de voorgenomen putboring nabij Amsterdam (Notes on the probable results of well drilling near Amsterdam): The Hague, Tijdschrift van het Koninklinjk Instituut van Ingenieurs, v. 9, p. 8-22.

Campbell, B.G., and Coes, A.L., eds., 2010, Groundwater availability in the Atlantic Coastal Plain of North and South Carolina: U.S. Geological Survey Professional Paper 1773, 241 p., 7 pls.

Cardinell, A.P., 1999, Application of continuous seismicreflection techniques to delineate paleochannels beneath the Neuse River at U.S. Marine Corps Air Station, Cherry Point, North Carolina: U.S. Geological Survey WaterResources Investigations Report 99-4099, 29 p.

Cardinell, A.P., Berg, S.A.; and Lloyd, O.B., Jr., 1993, Hydrogeologic framework of U.S. Marine Corps Base at Camp Lejeune, North Carolina: U.S. Geological Survey WaterResources Investigations Report 93-4049, 45 p.

Cardinell, A.P., Harned, D.A., and Berg, S.A., 1990, Continuous seismic reflection profiling of hydrogeologic features beneath New River, Camp Lejeune, North Carolina: U.S. Geological Survey Water-Resources Investigations Report 89-4195, 33 p.

Childs, Colin, 2004, Interpolating Surfaces in ArcGIS Spatial Analyst: ArcUser July - September 2004, ESRI, p. 32-35, accessed December 5, 2013, at $h t t p: / / w w w . e s r i . c o m / n e w s /$ arcuser/0704/summer2004.html

Coes, A.L., Spruill, T.B., and Thomasson, M.J., 2007, Multiple-method estimation of recharge rates at diverse locations in the North Carolina Coastal Plain, U.S.A.: Hydrogeology Journal, v. 15, p. 773-778.

Cronshey, R., McCuen, R., Miller, N., Rawls, W., Robbins, S., and Woodward, D., 1986, Urban hydrology for small watersheds ( $2 \mathrm{~d}$ ed.): U.S. Department of Agriculture, Soil Conservation Service, Engineering Division, Technical Release 55, 164 p.

Daniel, C.C., III, and Harned, D.A., 1998, Ground-water recharge and storage in the regolith-fractured crystalline rock aquifer system, Guilford County, North Carolina: U.S. Geological Survey Water-Resources Investigations Report 97-4140, $65 \mathrm{p}$.

Daniel, C.C., III, Miller, R.D., and Wrege, B.M., 1996, Application of geophysical methods to the delineation of paleochannels and missing confining units above the Castle Hayne aquifer at U.S. Marine Corps Air Station, Cherry Point, North Carolina: U.S. Geological Survey WaterResources Investigations Report 95-4252, 106 p. 
DePaul, V.T., Rice, D.E., and Zapecza, O.S., 2008, Waterlevel changes in aquifers of the Atlantic Coastal Plain, predevelopment to 2000: U.S. Geological Survey Scientific Investigations Report 2007-5247, 88 p.

Doherty, John, 2001, Using pilot points in PEST-ASP, in Guide to using groundwater Vistas Version 3: Herndon, Va., ESI, p. 171-198.

Doherty, John, 2003, Ground water model calibration using pilot points and regularization: Ground Water, v. 41, no. 2, p. $170-177$.

Doherty, John, 2005, PEST, Model independent parameter estimation user's manual (5th ed.): Watermark Numerical Computing, $336 \mathrm{p}$.

Doherty, John, and Hunt, R.J., 2010, Approaches to highly parameterized inversion-A guide to using PEST for groundwater-model calibration: U.S. Geological Survey Scientific Investigations Report 2010-5169, 59 p.

Eimers, J.L., Lyke, W.L., and Brockman, A.R., 1990, Simulation of ground-water flow in aquifers in Cretaceous rocks in the central Coastal Plain, North Carolina: U.S. Geological Survey Water-Resources Investigations Report 89-4153, $101 \mathrm{p}$.

Emsellem, Yves, and de Marsilly, Ghislan, 1971, An automatic solution for the inverse problem: Water Resources Research, v. 7 , no. 5 , p. 1264-1283.

Falls, W.F., Ransom, Camille, III, Landmeyer, J.E., Reuber, E.J., and Edwards, L.E., 2005, Hydrogeology, water quality, and saltwater intrusion of the Upper Floridan aquifer in the offshore area near Hilton Head Island, South Carolina, and Tybee Island, Georgia, 1999-2002: U.S. Geological Survey Scientific Investigations Report 2005-5134, $48 \mathrm{p}$.

Faye, R.E., and Valenzuela, C., 2007, Analyses of groundwater flow, Contaminant fate and transport, and distribution of drinking water at Tarawa Terrace, U.S. Marine Corps Base Camp Lejeune, North Carolina: Historical reconstruction and present-day conditions, Chapter C: Simulation of groundwater flow: Agency for Toxic Substances and Disease Registry, 94 p.

Fetter, C.W., 2001, Applied Hydrogeology (4 $4^{\text {th }}$ ed.): New Jersey, Prentice Hall, 598 p.

Fine, J.M., 2008, Hydrogeologic framework of Onslow County, North Carolina, 2008: U.S. Geological Survey Scientific Investigations Map 3055, 1 sheet.

Foyle, A.M., Henry, V.J., and Alexander, C.R., 2001, The Miocene aquitard and the Floridan aquifer of the Georgia/South Carolina coast - Geophysical mapping of potential seawater intrusion sites: Georgia Geologic Survey Bulletin 132, 61 p.
Fry, J., Xian, G., Jin, S., Dewitz, J., Homer, C., Yang, L., Barnes, C., Herold, N., and Wickman, J., 2011, Completion of the 2006 national land cover database for the conterminous United States: Photogrammetric Engineering \& Remote Sensing, v. 77, no. 9, p. 858-864.

Gellici, J.A., and Lautier, J.C., 2010, Chapter B-Hydrogeologic framework of the Atlantic Coastal Plain, North and South Carolina, in Campbell, B.G., and Coes, A.L., eds., Groundwater availability in the Atlantic Coastal Plain of North and South Carolina: U.S. Geological Survey Professional Paper 1773, p. 49-162.

Giese, G.L., Eimers, J.L., and Coble, R.W., 1997, Simulation of ground-water flow in the Coastal Plain aquifer system of North Carolina, in Regional Aquifer-System AnalysisNorthern Atlantic Coastal Plain: U.S. Geological Survey Professional Paper 1404-M, 142 p.

Halford, K.J., and Kuniansky, E.L., 2002, Documentation of spreadsheets for the analysis of aquifer-test and slug-test data: U.S. Geological Survey Open-File Report 02-197, $51 \mathrm{p}$.

Harbaugh, A.W., Banta, E.R., Hill, M.C., and McDonald, M.G., 2000, MODFLOW-2000, The U.S. Geological Survey modular ground-water model-User guide to modularization concepts and the ground-water flow process: U.S. Geological Survey Open-File Report 00-92, 121 p.

Harden, S.L., Howe, S.S., and Terziotti, Silvia, 2004, Direction of ground-water flow in the surficial aquifer in the vicinity of Impact Areas G-10 and K-2, Marine Corps Base Camp Lejeune, North Carolina, 2004: U.S. Geological Survey Scientific Investigations Report 2004-5270, accessed December 3, 2012, at http://pubs.water.usgs.gov/ sir2004-5270/.

Harned, D.A., Lloyd, O.B., Jr., and Treece, M.W., Jr., 1989, Assessment of hydrologic and hydrogeologic data at Camp Lejeune Marine Corps Base, North Carolina: U.S. Geological Survey Water-Resources Investigations Report 89-4096, $64 \mathrm{p}$.

Harrelson, L.G., and Fine, J.M., 2006, Selected well data used in determining ground-water availability in the North and South Carolina Atlantic Coastal Plain aquifer systems: U.S. Geological Survey Open-File Report 2006-1298, 81 p.

Haugh, C.J., 2002, Hydrogeology and ground-water-flow simulation of the Cave Springs area, Hixson, Tennessee: U.S. Geological Survey Water-Resources Investigations Report 02-4091, 57 p.

Healy, R.W., 2010, Estimating groundwater recharge: United Kingdom, Cambridge University Press, 245 p. 
Hem, J.D., 1985, Study and interpretation of the chemical characteristics of natural water: U.S. Geological Survey Water-Supply Paper 2254, 264 p.

Herzberg, B., 1901, Die Wasserversorgung einiger Nordseebader: Gasbeleuchtung und Wasserversorgung, v. 44, p. $815-819,842-844$.

Hill, M.C., 1998, Methods and guidelines for effective model calibration: U.S. Geological Survey Water-Resources Investigations Report 98-4005, 90 p.

Hill, M.C., and Tiedeman, C.R., 2007, Effective groundwater model calibration: With analysis of data, sensitivities, predictions, and uncertainty: New York, Wiley and Sons, 455 p.

Kinzelbach, W., Aeschbach, W., Alberich, C., Goni, I.B., Beyerle, U., Brunner, P., Chiang, W-H., Rueedi, J., and Zoellmann, K., 2002, A survey of methods for groundwater recharge in arid and semi-arid regions: Early warning and assessment report series: Nairobi, Kenya, United Nations Environmental Program, UNEP/DEWA/RS.02-2, 101 p.

Krug, W.R., and others, 1990, Map of the mean annual runoff for the northeastern, southeastern, and mid-Atlantic United States, water years 1951-80: U.S. Geological Survey WaterResources Investigations Report 88-4094, 11 p.

Kuniansky, E.L., 1989, Geohydrology and simulation of groundwater flow in the " 400 -foot," "600-foot," and adjacent aquifers, Baton Rouge area, Louisiana: Louisiana Department of Transportation and Development Technical Report 49, $88 \mathrm{p}$.

Kuniansky, E.L. and Danskin, W.R., 2003, Models gone bad-Common modeling problems and how to solve them, in Proceedings MODFLOW and More 2003: International Groundwater Modeling Institute, Golden Colo., p. 356-360.

Kuniansky, E.L., Gómez-Gómez, Fernando, and TorresGonzález, Sigfredo, 2004, Effects of aquifer development and changes in irrigation practices on ground-water availability in the Santa Isabel area, Puerto Rico: U.S. Geological Survey Water-Resources Investigations Report 03-4303, $56 \mathrm{p}$.

Kuniansky, E.L., Lowery, M.A., and Campbell, B.G., 2009, How processing digital elevation models can affect simulated water budgets: Ground Water, v. 47, no. 1, p. 97-107.

Langevin, C.D., Thorne, D.T., Jr., Dausman, A.M., Sukop, M.C., and Guo, Weixing, 2007, SEAWAT version 4-A computer program for simulation of multi-species solute and heat transport: U.S. Geological Survey Techniques and Methods, book 6, chap. A22, 39 p.
Lim, K.J., Engel, B.A., Tang, Zhenxu, Choi, Joongdae, Kim, K.S., Muthukrishnan, Suresh, and Tripathy, Dibyajyoti, 2005, Automated Web GIS based hydrograph analysis tool, WHAT: Journal of the American Water Resources Association, v. 41, no. 6, p. 1407-1416.

Lyke, W.L., and Winner, M.D., Jr., 1990, Hydrogeology of aquifers in Cretaceous and younger rocks in the vicinity of Onslow and southern Jones Counties, North Carolina: U.S. Geological Survey Water-Resources Investigations Report 89-4128, $49 \mathrm{p}$.

McCabe, G.J., McLaughlin, J.D., and Muller, R.A., 1985, Thornthwaite continuous monthly water budget-A computer program in basic for microcomputers: Louisiana State University Climate Paper 85-1, 20 p.

McSwain, K.B., and Nagy, L.A., 2011, Distribution of transmissivity and yield of the Surficial, Castle Hayne, and Peedee aquifers in northern New Hanover County, North Carolina: U.S. Geological Survey Open-File Report 2011-1205, 1 sheet.

Muller, R.A. and Larimore, P.B., Jr., 1975, Atlas of seasonal water budget components of Louisiana (1941-1970): C.W. Thornthwaite and Associates Publications in Climatology, v. 28 , No. 1 , p. 1-19.

Muller, R.A., and Thompson, R.C., 1987, Water budget analysis, in Oliver, J.E., and Fairbridge, R.W., eds., The encyclopedia of climatology: New York, Van Nostrand Reinhold, p. 914-921.

North Carolina Division of Water Resources, 2013a, Central Coastal Plain Capacity Use Area rules, accessed March 25, 2013, at http://www.ncwater.org/Permits_and_Registration/ Capacity_Use/Central_Coastal_Plain/ccpcualist.php.

North Carolina Division of Water Resources, 2013b, Local water supply plans, accessed March 25, 2013, at http://www.ncwater.org/Water_Supply_Planning/Local_ Water_Supply_Plan/.

North Carolina Division of Water Resources, 2013c, Ground water databases, accessed March 25, 2013, at http://www. ncwater.org/Data_and_Modeling/Ground_Water_ Databases/.

Payne, D.F., 2010, Effects of sea-level rise and pumpage elimination on saltwater intrusion in the Hilton Head Island area, South Carolina, 2004-2104: U.S. Geological Survey Scientific Investigations Report 2009-5251, 83 p., Webonly publication at $h t t p: / / p u b s . u s g s . g o v / s i r / 2009 / 5251 /$. 
Provost, A.M., Payne, D.F., and Voss, C.I., 2006, Simulation of saltwater movement in the Upper Floridan aquifer in the Savannah, Georgia-Hilton Head Island, South Carolina, area, predevelopment-2004, and projected movement for 2000 pumping conditions: U.S. Geological Survey Scientific Investigations Report 2006-5058, 124 p., accessed September 17, 2013, at http://pubs.usgs.gov/sir/2006/5058/.

Reilly, T.E., 2001, System and boundary conceptualization in groundwater flow simulation: U.S. Geological Survey Techniques of Water-Resources Investigations, Applications of Hydraulics, book 3, chap. B8, 30 p.

Reilly, T.E., and Harbaugh, A.W., 2004, Guidelines for evaluating ground-water flow models: U.S. Geological Survey Scientific Investigations Report 2004-5038, 30 p.

Rutledge, A.T., 1998, Computer programs for describing the recession of ground-water discharge and for estimating mean ground-water recharge and discharge from streamflow records-Update: U.S. Geological Survey Water-Resources Investigations Report 98-4148, 43 p.

Rutledge, A.T., 2000, Considerations for use of the RORA program to estimate ground-water recharge from streamflow records: U.S. Geological Survey Open-File Report 00-156, $44 \mathrm{p}$.

Sloto, R.A., and Crouse, M.Y., 1996, HYSEP: A computer program for streamflow hydrograph separation and analysis: U.S. Geological Survey Water-Resources Investigations Report 96-4040, 46 p.

Smith, D.G., and Chapman, M.J., 2005, Hydraulic properties of the surficial aquifer at five selected sites in the Little Contentnea Creek Basin, North Carolina, 2002-03: U.S. Geological Survey Scientific Investigations Report 2005-5238, $113 \mathrm{p}$.

Stewart, M., Cimino, M.R., 2007, Calibration of base flow separation methods with streamflow conductivity: Ground Water Journal, v. 45, no. 1, p. 17-27.

Stricker, V.A., 1983, Base flow in streams in the outcrop area of southeastern sand aquifer: South Carolina, Georgia, Alabama, and Mississippi: U.S. Geological Survey WaterResources Investigations Report 83-4106, 17 p.

Thornthwaite, C.W., 1948, An approach toward a rational classification of climate: Geographical Review, v. 38, no. 1, p. 55-94.

Thornthwaite, C.W., and Mather, J.R., 1955, The water balance: Publications in Climatology, v. 8, p. 9-86.

Thornthwaite, C.W., and Mather, J.R., 1957, Instructions and tables for computing potential evapotranspiration and the water balance: Publications in Climatology, v. 10, p. $185-311$.
U.S. Geological Survey, 2013a, National Elevation Dataset, accessed March 25, 2013, at http://ned.usgs.gov .

U.S. Geological Survey, 2013b, Water Use in the United States, accessed December 13, 2013, at http://water.usgs. gov/watuse/.

Westenbroek, S.M., Kelson, V.A., Dripps, W.R., Hunt, R.J., and Bradbury, K.R., 2010, SWB-A modified Thornthwaite-Mathre soil-water-balance code for estimating groundwater recharge: U.S. Geological Survey Techniques and Methods 6-A31, $60 \mathrm{p}$.

Winner, M.D., Jr., and Coble, R.W., 1996, Hydrogeologic framework of the North Carolina Coastal Plain, Regional Aquifer-System Analysis-Northern Atlantic Coastal Plain: U.S. Geological Survey Professional Paper 1404-I, 106 p., 14 pls. 

몰

흘

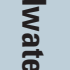

익

ํㅡㄹ

$\stackrel{2}{2}$

$\stackrel{\infty}{\bar{F}}$

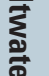

3

ช

$\stackrel{\Phi}{\Xi}$

ISSN 2328-0328 (online) 